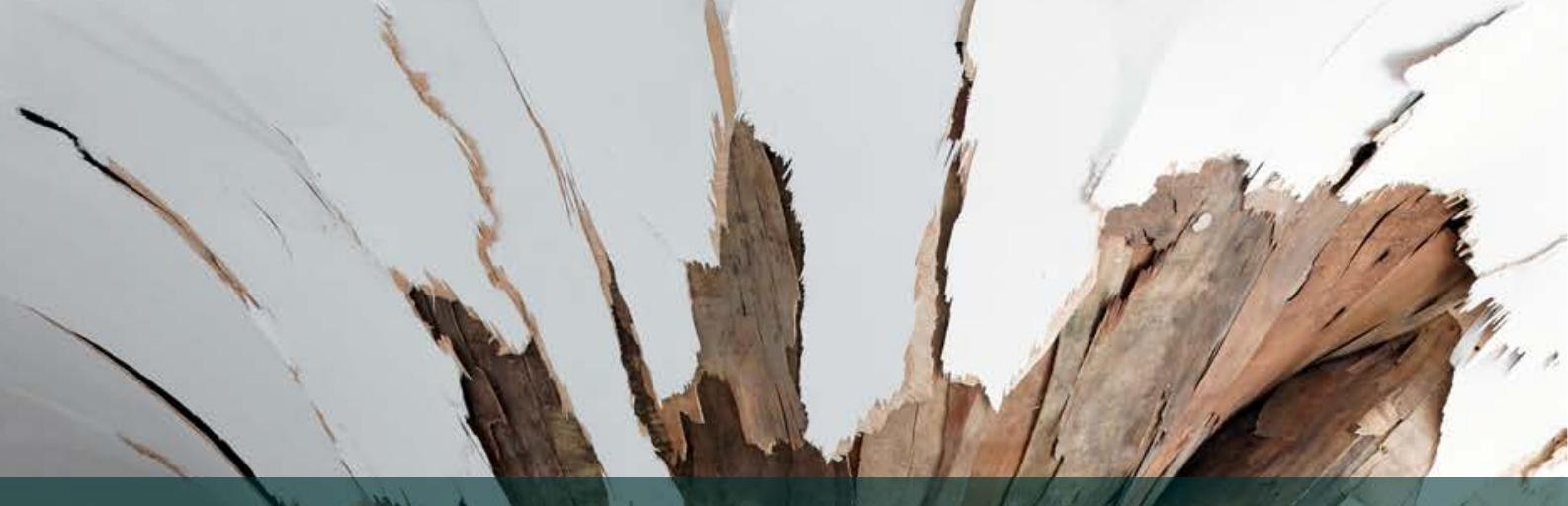

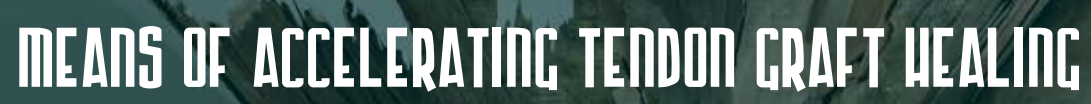
AFTER ACL RECOABTRMLTIIIT

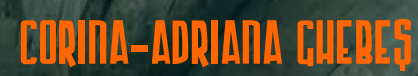

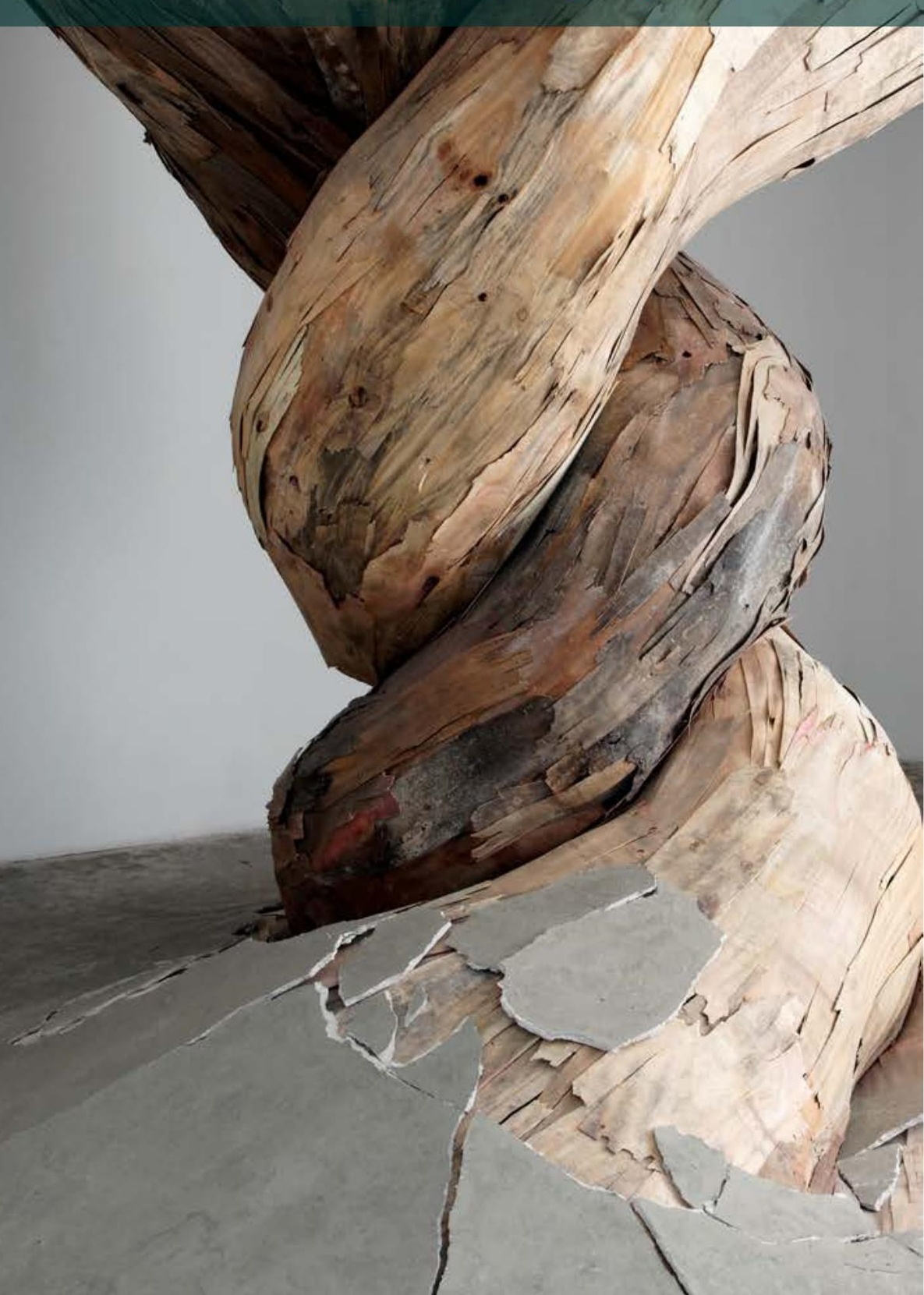




\section{Means of accelerating tendon graft healing after ACL reconstructions}




\section{Thesis Committee members}

Chairman: Prof.dr.ir. J.W.M. Hilgenkamp University of Twente

$\begin{array}{lll}\text { Promotors: } & \text { Prof.dr. D.B.F Saris } & \text { University of Twente } \\ & \text { Dr. H.A.M. Fernandes } & \text { University of Coimbra }\end{array}$

Members: Prof.dr. H.B.J. Karperien University of Twente

Prof.dr. P.C.J.J. Passier University of Twente

Prof.dr. G.J.V.M. van Osch University Medical Center Rotterdam

Prof.dr. R.L. Diercks University of Groningen

Dr. S.C. Fu University of Hong Kong

Means of accelerating tendon graft healing after ACL reconstruction

\section{Corina-Adriana Ghebeș}

PhD Thesis, University of Twente, Enschede, The Netherlands

ISBN: 978-90-365-4297-5

DOI: $10.3990 / 1.9789036542975$

The research described in this thesis was financially supported by University of Twente and Smith \& Nephew

Publication of this thesis was financially supported by the University of Twente and the Netherlands Society for Biomaterials and Tissue Engineering

(C) Corina-Adriana Ghebeş 2017

Cover: Artwork - Henrique Oliveira’s Desnatureza - Image by Aurélien Mole (C), courtesy Galerie Vallois, 2011. Used with permission of the artist, for which many thanks. Design by: T. van Eemeren.

The artwork is adopted here to represent the goal of this dissertation: to achieve a natural integration of the tendon graft into the bone after ACL reconstruction.

Printed by Gildeprint 


\title{
MEANS OF ACCELERATING TENDON GRAFT HEALING AFTER ACL RECONSTRUCTION
}

\section{DISSERTATION}

\author{
To obtain \\ the degree of doctor at the University of Twente, \\ on the authority of the rector magnificus \\ Prof. dr. T.T.M. Palstra
}

on account of the decision of the graduation committee, to be publicly defended on Friday the $3^{\text {rd }}$ of March 2017 at 14:45

by

Corina-Adriana Ghebeş

born on June $20^{\text {th }}, 1986$

in Sibiu, Romania 
This dissertation has been approved by:

Promoter: $\quad$ Prof.dr. D.B.F. Saris

Co-promoter: Dr. H.A.M. Fernandes 


\section{TABLE OF CONTENTS}

Summary 2

Samenvatting $\quad 4$

CHAPTER 1

General introduction and thesis outline

\section{CHAPTER 2}

Anterior cruciate ligament- and hamstring tendon-derived cells: in vitro differential properties of cells involved in ACL reconstruction

\section{CHAPTER 3}

Means of enhancing bone fracture healing: optimal cell source, isolation methods, and acoustic stimulation

\section{CHAPTER 4}

Human muscle-derived factors accelerate ACL graft healing: an in vitro and in vivo analysis

\section{CHAPTER 5}

High-Throughput Screening Assay Identifies Small Molecules Capable of Modulating the BMP-2 and TGF- $\beta 1$ Signalling Pathway

\section{CHAPTER 6}

Infographic A View on the World of Musculoskeletal Tendon and Ligament Research

\section{ChAPTER 7}

General Discussion 


\section{SUMMARY}

Rupture of the anterior cruciate ligament (ACL) is one of the most common sportrelated injuries. As the ACL is unable to repair itself, reconstructive surgery remains the number one option for the restoration of joint function and the achievement of nearlynormal joint kinematics and kinetics. The current practice of surgical ACL reconstruction uses autografts, such as tendon grafts, to replace the native ligament and ensure a good clinical outcome. Successful ACL reconstruction with a tendon graft requires a strong bond between the soft tissue (graft) and hard tissue (bone) in the femoral and tibial tunnels, followed by functional adaptation and remodelling to resemble the structural properties of the native ACL. After surgery, this process takes approximately 12 months. This relatively long recovery period hinders patients from returning to normal daily activities. The longer they are incapable of normal ambulation and more strenuous activities, the more their muscle and motor skills decline, subsequently causing further delay. This vicious cycle must be broken. The demand for solutions capable of shortening graft healing has prompted scientists to explore new ideas and strategies to improve clinical practice in ACL reconstruction surgery. This thesis has explored three of these approaches to advance ACL healing: harvesting and priming bone marrow cells, utilising the potential of muscle-derived signals and identifying small molecules that can modulate important signalling pathways.

This research has first evaluated the tissue-regenerative properties of the tendon graft compared to the native ligament through an in vitro analysis of the phenotype of cells derived from each tissue. Next, it has identified that the cells lack regenerative properties. The consequent task has been to find cells that do have these properties, as well as osteoinductive properties, that can be used in the ACL reconstruction practice. These properties are found in bone marrow cells that are commonly derived from the ilium. For ACL reconstruction, sourcing these cells proximal to the knee junction would be optimal. However, our comparative study of different bone marrow cell sources has shown that cells derived from the ilium offer the strongest regenerative properties. To enhance these properties further, this research has also investigated different priming methods, such as acoustic stimulation and selection of cells through different isolation methods. Optimisation of the cell source and priming conditions forms a basis for applying these cells in ACL reconstruction research.

This research has used an indirect co-culture system for an in vitro simulation of the crosstalk between different cell types that contribute to the development of tendons and ligaments during embryogenesis. This has revealed that myoblast-derived signals are capable of upregulating classical tendon/ligament gene expression markers on tendonderived cells, which can contribute to ACL graft healing. Whole transcriptome analysis has shown that co-culturing tendon-derived cells with myoblasts leads to an upregulation of extracellular matrix (ECM) genes and results in enhanced ECM deposition. Using a rat model of ACL reconstruction, we demonstrated in vivo that conditioned media derived from muscle tissue accelerates femoral tunnel closure, a key 
step for autograft integration. Collectively, these results indicate that muscle-derived signals can be employed to improve ACL graft healing in a clinical setting, where muscle remnants are often discarded.

Modulation of bone morphogenetic protein 2 (BMP-2) and transforming growth factor$\beta 1$ (TGF- $\beta 1$ ) signalling pathways is essential during tendon/ligament healing. Unfortunately, growth factor delivery in situ is far from trivial and, in many cases, the necessary growth factors are not approved for clinical use. This research has used a BMP-2 and a TGF- $\beta 1$ reporter cell line to screen a library of 1,280 small molecules approved by the Food and Drug Administration, which has led to the identification of modulators of both signalling pathways. This report presents four relevant compounds and a description of their effects on proliferation and differentiation of tendon-derived cells.

Undoubtedly, this research does not stand alone, but is part of a more extensive field of tendon/ligament research of the musculoskeletal system. While solutions are highly specialised, advancements in the field may benefit from a holistic perspective of the field itself. This research concludes by mapping the field, both visually and conceptually. This visualisation of the world of musculoskeletal tendon and ligament research aims to provide a quick overview of the main contributors to the field and the areas of interest. 


\section{SAMENVATTING}

Letsel aan de voorste kruisband (anterior cruciate ligament (ACL) in het Engels) is een van de meest voorkomende sportgerelateerde blessures. Omdat de ACL zichzelf niet kan herstellen, blijft reconstructieve chirurgie de beste optie om de gewrichtsfunctie snel te herstellen en voor een nagenoeg normale gewrichtskinematica en -kinetiek. In de huidige praktijk van chirurgische ACL-reconstructie wordt gebruikgemaakt van autotransplantaties zoals peestransplantaties, om het natuurlijke ligament te vervangen en te zorgen voor een klinisch goed resultaat. Een succesvolle ACL-reconstructie met een peestransplantaat vereist een sterke band tussen het zachte weefsel (transplantaat) en het harde weefsel (bot) in de femorale en tibiale tunnels, gevolgd door een functionele aanpassing en reorganisatie om de structuureigenschappen van de oorspronkelijke ACL na te bootsen. Na de operatie duurt dit proces ongeveer twaalf maanden. Deze relatief lange herstelperiode belemmert patiënten de normale dagelijkse activiteiten op te pakken. Hoe langer ze niet in staat zijn om normaal te lopen en inspannendere activiteiten te ondernemen, hoe meer hun spieren en motorische vaardigheden afnemen. Dit zorgt voor verdere vertraging van het herstel. Daarom moet deze vicieuze cirkel worden doorbroken. De vraag naar oplossingen om de duur van het herstel na een transplantatie te verkorten, heeft wetenschappers aangespoord nieuwe ideeën en strategieën te onderzoeken die de klinische praktijk van de ACLreconstructiechirurgie kunnen verbeteren. Deze dissertatie heeft drie van deze benaderingen om ACL-revalidatie te bevorderen onderzocht: afname en priming van beenmergcellen, gebruikmaken van het potentieel van spier-afgeleide signalen en identificeren van kleine moleculen die belangrijke signaalpaden kunnen moduleren.

Dit onderzoek heeft eerst de weefsel-regeneratieve eigenschappen van het peestransplantaat vergeleken met het oorspronkelijke ligament door een in-vitroanalyse van het fenotype van cellen die afgeleid zijn van elk weefsel. Vervolgens is vastgesteld dat de cellen geen regeneratieve eigenschappen bezitten. Daaruit is voortgekomen dat er een taak ligt om cellen te vinden die deze eigenschappen wel hebben en osteoinductieve eigenschappen te achterhalen die kunnen worden gebruikt in de reconstructie van ACL. Deze eigenschappen zijn aangetroffen in de beenmergcellen die gewoonlijk zijn afgeleid van het darmbeen. Voor een ACL-reconstructie zou sourcing van de cellen in de buurt van het kniegewricht het best zijn. Ons vergelijkingsonderzoek naar beenmergcellenbronnen heeft echter aangetoond dat cellen die afgeleid zijn van het darmbeen de sterkste regeneratieve eigenschappen hebben. Om deze eigenschappen verder te verbeteren, heeft dit onderzoek ook verschillende priming-methoden onderzocht, zoals akoestische stimulatie en selectie van cellen door verschillende isolatiemethoden. Een optimalisatie van de celbron en de priming-voorwaarden vormt een basis voor de toepassing van deze cellen in een ACL-reconstructieonderzoek.

Dit onderzoek heeft een indirect co-kweeksysteem gebruikt voor een in-vitrosimulatie van de crosstalk tussen verschillende celtypen die tijdens de embryogenese aan de ontwikkeling van pezen en ligamenten bijdragen. Hieruit is gebleken dat signalen van 
de myoblast opwaarts klassieke pees- en ligamentgenexpressiemarkers op de peesafgeleide cellen kunnen reguleren, die aan de ACL-transplantaatrevalidatie kunnen bijdragen. Een volledige transcriptoomanalyse heeft aangetoond dat het co-kweken van pees-afgeleide cellen met myoblasten leidt tot een opwaartse regulatie van extracellulaire matrix (ECM-)genen en resulteert in een verbeterde ECM-depositie. Middels het gebruik van een ratmodel voor ACL-reconstructie hebben we in vivo aangetoond dat geconditioneerde media die afgeleid zijn van spierweefsel een femorale tunnelsluiting versnellen. Dit is een belangrijke stap voor de integratie van autotransplantatie. Alle resultaten wijzen erop dat spier-afgeleide signalen kunnen worden ingezet ter verbetering van de ACL-transplantatierevalidatie in een klinische setting, waarbij de spierresten vaak worden verwijderd.

Tijdens de pees- of ligamentrevalidatie is het essentieel dat het bot-morfogenetische eiwit 2 (BMP-2) en de signaalpaden van de transformerende groeifactor- $\beta 1$ (TGF- $\beta 1$ ) moduleren. Groeifactorlevering ter plaatse is helaas verre van triviaal en in veel gevallen zijn de benodigde groeifactoren niet goedgekeurd voor klinisch gebruik. In dit onderzoek zijn een BMP-2 en de TGF- $\beta 1$-reportercellijnen gehanteerd om een reeks van 1,280 kleine moleculen te onderzoeken, die zijn goedgekeurd door de FDA (Food and Drug Administration). Dit onderzoek heeft geleid tot de identificatie van modulatoren van beide signaalpaden. Dit verslag presenteert vier relevante verbindingen en een beschrijving van de gevolgen daarvan voor de proliferatie en differentiatie van de peesafgeleide cellen.

Dit onderzoek staat niet op zichzelf, maar is onderdeel van een uitgebreider onderzoeksveld dat gericht is op de pezen en ligamenten van het bewegingsapparaat. Terwijl de oplossingen zeer gespecialiseerd zijn, kunnen de ontwikkelingen op dit gebied profiteren van een holistisch perspectief op het onderzoeksgebied zelf. Ten slotte is het onderzoeksveld zowel visueel als conceptueel in kaart gebracht. Deze visualisatie van de wereld van pees- en ligamentonderzoek heeft als doel een overzicht te bieden van de belangrijkste bijdragen en interessegebieden binnen het veld. 

Chapter 1

\section{General introduction and thesis outline}




\section{INTRODUCTION}

Rupture of the anterior cruciate ligament (ACL) is one of the most common sportrelated injuries. Unable to self-repair, reconstructive surgery remains the number one option to restore joint function aiming for rapid recovery and attempting to achieve close to normal join kinematics and kinetics. Current surgical ACL reconstruction practice uses autografts, such as tendon grafts, to replace the native ligament and ensure a good clinical outcome. Successful ACL reconstruction with a tendon graft requires, a strong bond between the soft (graft) and the hard tissue (bone) in the femoral and tibial tunnels, followed by functional adaptation and remodelling to resemble the structural properties of the native ACL. This process is currently only sufficiently healed approximately 12 months after surgery [1], which hinders patients return to normal daily activities and affects their quality of life. The longer they are incapable of normal ambulation and more strenuous activities the more muscle and motor skills are lost. This in turn causes delay in return to normal life and sports. This vicious circle needs to be broken to allow patients more rapid and better return to their desired activities after ACL reconstruction. Solutions capable of shortening graft healing are much needed, prompting scientists to explore new ideas/strategies to improve clinical practice in ACL reconstruction surgery.

Studies report an incidence rate of ACL rupture between 36.9 and 60.9 per 100,000 people per year [2, 3]. ACL rupture often results from twisting or bending the knee [4] and causes significant joint instability that, if left untreated, can cause meniscus tears, cartilage defects and generalised osteoarthritis [5, 6]. Unfortunately, the ACL's low cellularity, poor vascularization, and a surrounding hostile intra-articular environment $[7,8]$ do not provide an adequate healing response that can bridge the gap between the ruptured ends of the ACL $[9,10]$.

\section{ACL RECONSTRUCTION}

Today, ACL reconstruction is the standard care procedure to restore function [11]. Several reconstructive procedures have been proposed in the past few decades, differing mainly in terms of graft selection and surgical technique. The autologous graft remains the most popular method for ACL reconstruction, however, and is considered the 'gold standard' because of the high rate of success (85-90\%) regarding long-term clinical outcomes [12]. One such graft is the hamstring tendon, which, given its mechanical and structural similarities to the native ACL [13] and low morbidity at the harvest site [14], has made it a logical choice for ACL reconstruction $[15,16]$. Using the most common ACL reconstruction technique, bone tunnels are drilled into the tibia and femur and the hamstring tendon graft is inserted onto the footprints of the original ACL. The remnant muscle tissue is removed from the graft and the graft is pulled through the bone tunnels and fixed in place [17] (Figure 1). Because the hamstring tendon graft does not have bone plugs, tendon-to-bone healing is largely dependent on the osteointegration of the grafted tendon into the bone tunnels. It may take up to 12 months before a functional 
tissue, closely resembling the structural properties of the native ACL, is established and capable of guaranteeing a safe return to similar pre-injury levels of activity [18]. This long recovery after surgery affects patient expectations, especially young individuals and athletes who aim to return soon to high-level sporting activities. Because an earlier return to sports may increase the risk of reincidence, patients are obliged to wait until the transplanted graft is fully remodelled. A firm attachment of the tendon graft to the bone is a crucial factor in facilitating an early aggressive rehabilitation and a rapid return to sports and full activity.

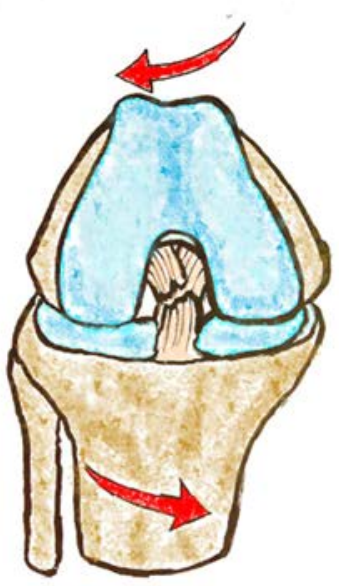

ACL rupture

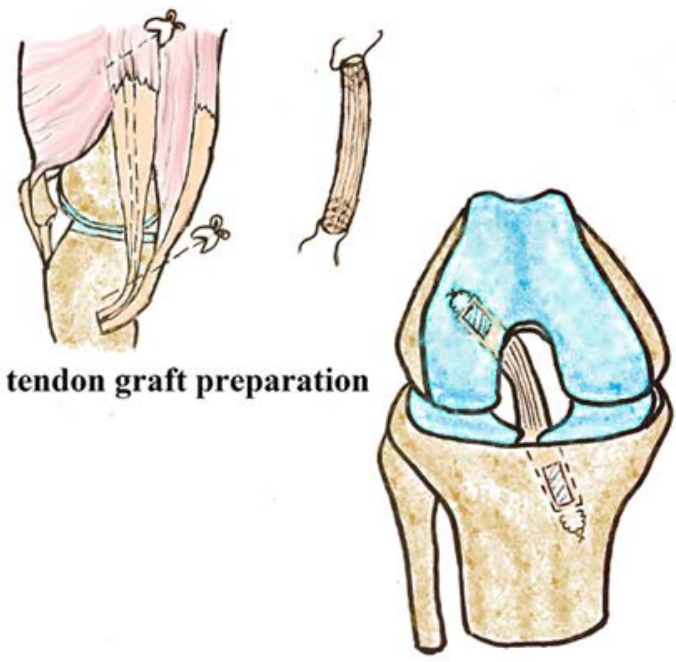

ACL reconstruction

Figure 1. Surgical reconstruction procedure following ACL rupture. The hamstring tendon graft is harvested; remnant muscle tissue is removed from the graft; and the graft is pulled through the bone tunnels and fixed in place.

The native ACL insertion into bone is a highly-specialized tissue, comprising a complex transition zone from the ligament to the bone. This transition zone consists of the ligament proper, non-mineralised fibrocartilage, mineralised fibrocartilage, and bone [19] and plays a crucial role in the biomechanics of the knee joint. To restore this interface, progressive mineralisation of the tendon-bone interface must occur. An incorporation of the tendon graft into the surrounding bone, followed by bone ingrowth into the grafts, contributes to the regeneration of the tendon-to-bone junction. To date, there is no proof for an absolute regeneration of this complex transition zone following ligament reconstruction [20] and, perhaps as a consequence, the properties of the grafted tissue remain inferior to the native tissue.

Prior attempts to improve tendon-graft healing include both intraoperative and extracorporeal intervention. A summary and description of these strategies are presented below, and there is a schematic representation in Figure 2. 


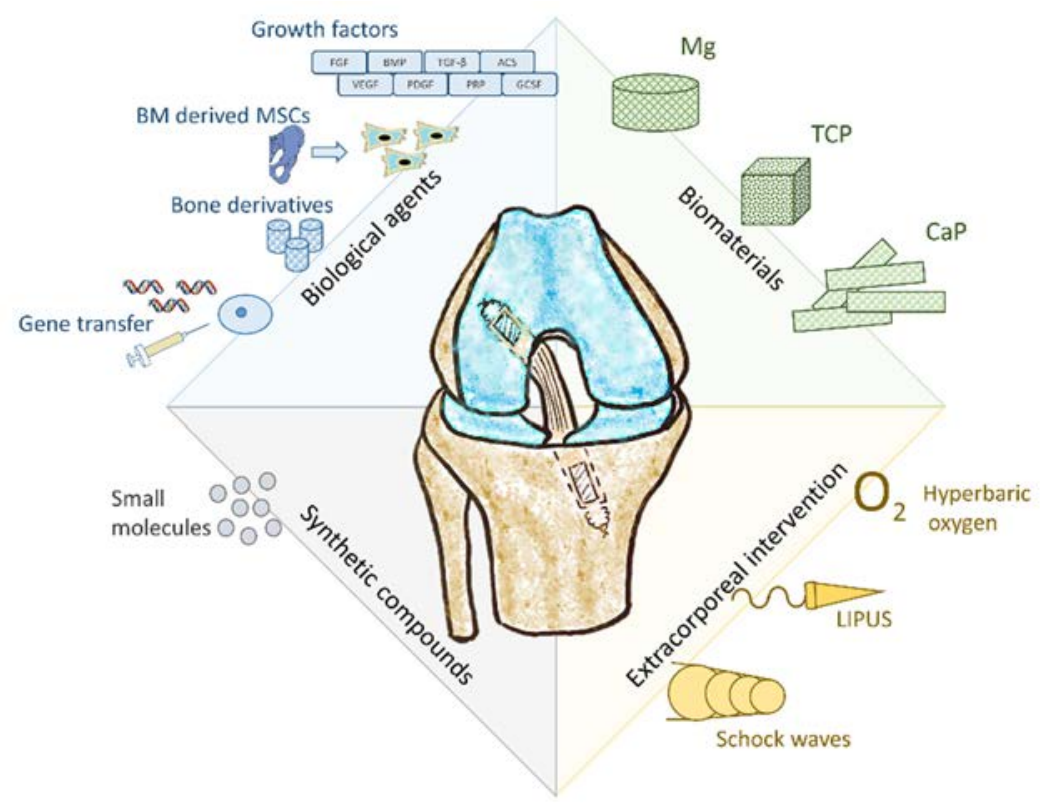

Figure 2. Various strategies employed to stimulate tendon-graft healing.

\section{INTRAOPERATIVE INTERVENTION}

Intraoperative interventions include the use of agents and materials, such as biological agents, biomaterials, and small molecules, administered during ACL reconstruction, to provide appropriate molecular signals able to induce tissue specific cell proliferation, differentiation, deposition of extracellular matrix, neovascularisation, or neuroregeneration

\section{Biological agents}

Various biological-based strategies have been proposed involving techniques that can improve the biomechanical, biochemical, and/or biological properties of the tendon graft. Such strategies involve the use of a variety of cells, growth factors, platelet-rich plasma (PRP), periosteum, and gene transfer.

\section{Cell-based therapy}

Mesenchymal stromal cells (MSCs), harvested from bone marrow, synovium, or umbilical cord blood [21-23], have been proposed to augment ACL reconstruction. Flourishing preclinical literature suggests that MSC administration can stimulate tissue maturation, improve histological appearance, and favour bone-to bone integration [24]. Using a rabbit model for ACL reconstruction, it has been shown that MSCs embedded within fibrin glue and implanted into the bone tunnel contributed to the formation of a 
fibrocartilage interface at the junction that more closely resembles that of a normal ACL [23]. Further studies using similar approaches have shown comparable positive results at the tendon graft to bone integration [22, 25-27]. It seems that MSCs improve the insertion of the graft into the bone, recapitulating some of the features of the natural tissue. The exact mechanism of action of the transplanted MSCs on tendon-bone healing is still largely unknown, however.

In clinical studies, the application of MSCs have been introduced, especially in the field of cartilage regeneration/osteoarthritis; with 18 completed clinical studies found in PubMed and 50 clinical trials listed on clinicaltrials.gov, this carries promise of more breakthrough discoveries [28, 29]. Regarding ACL healing following reconstruction, only one clinical study was identified that used MSCs by the application of bone marrow concentrate harvest from ilium. This study was unable to provide a clear understanding of the actual contribution of the MSCs from bone marrow concentrate to tendon-graft bone tunnel healing [30]. Unfortunately, no characterisation of the aspirate, viability, or numeration of the mononuclear cells (MNCs) was completed on any sample. Since it is possible to obtain MSCs from different sources, and MNC concentration might play a significant role in the augmentation of ACL reconstruction, it would be interesting to determine which source can play a major role in achieving a positive clinical outcome.

The periosteum represents an additional cell-based therapeutic strategy proposed to enhance tendon-graft bone tunnel healing. Consisting of multipotent mesodermal cells that have the capacity to form cartilage and bone, it is used as a wrap around the tendon and inserted into the bone tunnel. Results obtained from preclinical studies showed the formation of fibrocartilage and bone regeneration around the tendon graft [31-34]. Few clinical studies report satisfactory outcomes in patients undergoing ACL reconstruction with periosteum-enveloping tendon-graft technique, however, with regard to bone tunnel enlargement [35, 36].

A new cell-based therapeutic strategy has shown admirable performance on tendonbone healing in preclinical studies. ACL-derived CD34+ cells have been shown to enhance tendon-bone healing in ACL reconstruction animal models, mostly by enhancing angiogenesis and osteogenesis [37, 38]. Matsumoto et al. revealed the presence of abundant vascular stem cells with a characteristic expression of CD34+ in the injured ACL tissues, which displayed higher expansion and multiple lineage differentiation potential than CD34- cells [39]. In a further study, ACL-derived CD34+ cells were injected into nude mice articular cavities after ACL reconstruction, where more fibrocartilage cells, as well as enhanced angiogenesis and osteogenesis, were suggested in a CD34+ sorted group [38]. Additionally, CD34+ cells were previously isolated from peripheral blood or bone marrow and recognised as a rich population of haematopoietic/endothelial progenitor cells, which have been already used in clinical settings for the repair of various damaged tissues [40]. This can ease their path to clinical application in ACL reconstruction. Isolated from the site of ACL rupture, these cells can provide an important contribution to tendon-bone healing and regeneration. 


\section{Growth factors}

Platelet-rich plasma (PRP) is an autologous blood-derived product obtained by centrifugation or filtration of peripheral blood to concentrate the platelets. It represents a reservoir of several growth factors and bioactive molecules involved in tissue homeostasis and anabolism [41]. Preclinical studies have shown that application of PRP can promote better and faster ligamentisation of the graft, reduce the proinflammatory factors released immediately after the surgery and contribute, to a less extent, to a better tendon-graft bone integration [42, 43]. In clinical studies, however, the benefits of PRP application in providing a faster and better functional outcome are inconclusive. The addition of platelet concentrate to ACL reconstruction shows a 20 to 30\% improvement on graft maturation (progression of cellularity, vessel density, and histologic signs of graft maturity) but with substantial variability, while no significant difference in graftbone interface healing was observed [44-46].

Targeting specific growth factors can have more promising results than generic PRP injections. Overdosing with PRP can overstimulate the cells, leading to poor differentiation and chaotic scar formation, or might precipitate adverse events such as suppression of osteoclast generation [47].

Bone morphogenetic proteins (BMPs) have been widely acknowledged for their role in cellular differentiation and bone formation. Numerous preclinical studies have reported positive effects of BMP-2 and BMP-7 on healing after ACL reconstruction, mostly by improving the integration between tendon and bone [25, 48-51]. Transforming growth factor beta (TGF- $\beta$ ) has been shown to stimulate matrix protein deposition by generating perpendicular collagen fibres connecting the tendon graft and bone and ultimately increasing the maximum load in preclinical studies. It also modulates tissue healing and remodelling through chemotaxis of neutrophils and monocytes to the wound site $[52,53]$. Fibroblast growth factor (bFGF) and vascular endothelial growth factor (VEGF) have been shown to contribute to fibrous integration between the tendon and bone via vascularisation [25, 54]. Furthermore, granulocyte colony-stimulating factor has been suggested to enhance the ultimate strength and accelerate bone development of the graft in experimental ACL reconstruction animal models [55], while hepatocyte growth factor has been suggested to promote the adhesive healing process at the tendon-bone junction [56]. Finally, platelet-derived growth factor-BB (PDGF-BB) has been shown to increase vascularity and collagen deposition. The application of PDGF-BB on graft incorporation using an ACL model in sheep resulted in higher biomechanical strength, higher vascular density, and higher levels of collagen fibril [57]. Despite their positive role in preclinical studies, only PDGF and autologous conditioned serum (ACS) were introduced in clinical settings to accelerate the healing process following ACL reconstruction. PDGF proved to have limited effect on clinical score, inflammatory markers, or graft appearance on MRI [58, 59], while ACS showed decreased bone tunnel widening [60]. None of this has found its way into clinical practice. 


\section{Gene therapy}

Gene transfer of therapeutic factors has been developed to accelerate tissue healing, which overcomes the limitations of the direct use of growth factors [61]. Sustained delivery of BMP-2 via gene transfer has been shown to enhance the behaviour of the cells in a manner that improves bone healing response at the tendon-bone interface [50, 62]. Reconstructed tendon-bone interface with PDGF-B transfected bone marrow derived MSCSs enhanced vascularity and collagen deposition [63]. Additionally, viral vector mediated gene transfer of bFGF (both in vitro and in experimentally injured human ACLs) significantly enhanced collagen production and neovascularisation [64, 65].

\section{Bone derivative}

Application of the recombined bone xenograft within the bone tunnels following ACL replacement, such as demineralised bone matrix or enamel matrix derivatives, represent a further source of BMPs that can enhance tendon-bone healing and tendon-bone fixation strength by inducing an increase in the growth of fibrocartilage and mineralised fibrocartilage at the tendon-bone interface $[66,67]$. As yet, the role of bone derivatives in clinical setting of ACL reconstruction and graft healing has not been assessed.

\section{Biomaterials}

Osteoconductive agents such as calcium phosphate $(\mathrm{CaP})$, hydroxyapatite, tricalcium phosphate (TCP), brushite CaP cement, and magnesium adhesive have been used to fix the tendon graft into the bone tunnel and improve its healing via enriched bone ingrowth [68-71]. Some of this technology is used in fixation devices. Currently, one ongoing clinical study is evaluating the application and performance of these materials in revision ACL reconstruction [72].

\section{Small molecules}

Simvastatin has been reported to improve endothelial function, have an antiinflammatory, and to stimulate angiogenesis and bone formation by activating the promoter of the BMP-2 gene [73-76]. Using a rabbit model, a previous study showed that the local administration of low-dose simvastatin-conjugated gelatin hydrogel promoted tendon-to-bone healing during the early phase following ACL reconstruction by enhancing angiogenesis and osteogenesis [77]. Another small molecule, alendronate, has been reported to reduce bone resorption. Using a rat model, the administration of alendronate has been shown to reduce bone resorption and increase mineralised tissue formation inside the bone tunnel $[78,79]$. The use of these therapeutic small molecules represents an important alternative to growth factors. Unlikely to induce immune response in the host because they are too small to do so [80], and with no risk of crossspecies contamination, as in the case of recombinant protein-based applications [81], small molecules represent the next generation of therapeutic approach. 


\section{Extracorporeal intervention}

Extracorporeal interventions, such as low-intensity pulsed ultrasound (LIPUS), hyperbaric oxygen, or shock waves are noninvasive therapies that have been used immediately following ACL reconstruction to enhance tendon-to-bone healing. These interventions use mechanotransduction as a mechanism to induce osteogenesis and neoangiogenesis and thus improve local tissue regeneration and remodelling [82-84].

The abovementioned strategies demonstrate the challenge of achieving a secure fix between the tendon graft and the bone tunnel. A current dichotomy between the flourishing preclinical literature and the limited and inconclusive data coming from clinical studies highlights not only the insufficient understanding of the mechanism of action of these powerful agents but also the need for new approaches with better impact on clinical outcomes.

\section{AIM OF THE THESIS}

This work aims to find new strategies capable of accelerating tendon-graft healing and improving the future practice of ACL reconstruction in a practical and clinically applicable manner.

\section{OUTLINE OF THE THESIS}

The current chapter provides a description of the challenge and a summary of ongoing approaches that aim to address these challenges (Chapter 1).

Given the insufficient regenerative properties of ACL tissue to heal following a severe injury, and the poor healing properties of the tendon graft following ACL reconstruction, it is important to determine the differences in regenerative properties between the 'to be replaced and the new tissue graft'. This can influence the direction of investigation and the development of strategies to accelerate tendon-graft healing. An evaluation of tissue regenerative properties was achieved by analysing in vitro the phenotype of cells derived from each tissue (Chapter 2).

Based on the information in the previous chapter, that tendon-graft derived cells seem to lack regenerative properties. Aiming for an integration of the tendon graft into the bone, we searched for appropriate cells with regenerative and osteoinductive properties. As an additional project, this chapter provides information regarding possible bone marrow cell sources or cell-priming methods to enhance bone regeneration and implicit enhance tendon-bone tunnel integration (Chapter 3).

Next we provide important evidence (at both in vitro and in vivo levels) that the actual remnant muscle tissue, discarded during ACL reconstruction, can have a beneficial contribution to accelerating tendon-graft healing (Chapter 4). Using a mix of cell types (derived from different tissues), we investigated the influence of intercellular 
communication on the expression of genes that direct cell differentiation and extracellular matrix formation. Further analysis, using an in vivo ACL reconstruction rat model, provides proof of concept evidence that remnant muscle tissue releases factors that can accelerate tendon-graft healing.

Our next approach identifies small molecules that can modulate two essential signalling pathways in tendon-graft healing (Chapter 5). Using BMP-2 and TGF- $\beta 1$ reporter cell lines, we screened a library of small molecules approved by the FDA (Food and Drug Administration) and identified four compounds able to modulate both signalling pathways. Subsequent assays used primary tendon cells to investigate the effect of the selected molecules in tendon cell metabolism and differentiation potential.

Eager to understand the reason why, after decades of research, healing of the ACL (as well as of other ligaments and tendons $(\mathrm{L} / \mathrm{T})$ ) still represents a persistent clinical challenge, we approached the current research field of L/T from a perspective other than the usual reviews (Chapter 6). A world map summarising the main contributors in the field of $\mathrm{L} / \mathrm{T}$ and a graphic representation of their main interest can help provide answers to the question and guide researchers towards quickly advancing research in $\mathrm{L} / \mathrm{T}$ healing.

Ultimately, in the final chapter, we discuss the important findings of this thesis, and reflect upon the relevance these findings have in immediate translation into clinical applications. 


\section{REFERENCES}

1. Fu FH, Bennett Ch Fau - Ma CB, Ma Cb Fau - Menetrey J, Menetrey J Fau - Lattermann C, Lattermann C: Current trends in anterior cruciate ligament reconstruction. Part II. Operative procedures and clinical correlations. (0363-5465 (Print)).

2. Gianotti SM, Marshall SW, Hume PA, Bunt L: Incidence of anterior cruciate ligament injury and other knee ligament injuries: a national population-based study. Journal of science and medicine in sport / Sports Medicine Australia 2009, 12(6):622-627.

3. Parkkari J, Pasanen K, Mattila VM, Kannus P, Rimpela A: The risk for a cruciate ligament injury of the knee in adolescents and young adults: a population-based cohort study of 46500 people with a 9 year follow-up. British journal of sports medicine 2008, 42(6):422-426.

4. Wu JL, Seon JK, Gadikota HR, Hosseini A, Sutton KM, Gill TJ, Li G: In situ forces in the anteromedial and posterolateral bundles of the anterior cruciate ligament under simulated functional loading conditions. The American journal of sports medicine 2010, 38(3):558-563.

5. Lohmander LS, Ostenberg A Fau - Englund M, Englund M Fau - Roos H, Roos H: High prevalence of knee osteoarthritis, pain, and functional limitations in female soccer players twelve years after anterior cruciate ligament injury. (0004-3591 (Print)).

6. Levine JW, Kiapour AM, Quatman CE, Wordeman SC, Goel VK, Hewett TE, Demetropoulos CK: Clinically relevant injury patterns after an anterior cruciate ligament injury provide insight into injury mechanisms. The American journal of sports medicine 2013, 41(2):385-395.

7. Murray MM, Fleming BC: Biology of anterior cruciate ligament injury and repair: Kappa delta ann doner vaughn award paper 2013. Journal of orthopaedic research : official publication of the Orthopaedic Research Society 2013, 31(10):1501-1506.

8. Maletius W, Messner K: Eighteen- to Twenty-four-Year Follow-up After Complete Rupture of the Anterior Cruciate Ligament. The American journal of sports medicine 1999, 27(6):711-717.

9. Murray MM, Martin SD, Martin TL, Spector M: Histological changes in the human anterior cruciate ligament after rupture. J Bone Joint Surg Am 2000, 82-A(10):1387-1397.

10. Bray RC, Leonard CA, Salo PT: Vascular physiology and long-term healing of partial ligament tears. Journal of orthopaedic research : official publication of the Orthopaedic Research Society 2002, 20(5):984-989.

11. West RV, Harner CD: Graft selection in anterior cruciate ligament reconstruction. The Journal of the American Academy of Orthopaedic Surgeons 2005, 13(3):197-207.

12. Leong NL, Petrigliano FA, McAllister DR: Current tissue engineering strategies in anterior cruciate ligament reconstruction. Journal of biomedical materials research Part A 2014, 102(5):1614-1624.

13. Bogunovic L, Yang JS, Wright RW: Anterior Cruciate Ligament Reconstruction: Contemporary Revision Options. Operative Techniques in Sports Medicine, 21(1):64-71.

14. Biau DJ, Katsahian S, Kartus J, Harilainen A, Feller JA, Sajovic M, Ejerhed L, Zaffagnini S, Röpke M, Nizard R: Patellar Tendon Versus Hamstring Tendon Autografts for Reconstructing the Anterior Cruciate Ligament: A MetaAnalysis Based on Individual Patient Data. The American journal of sports medicine 2009, 37(12):2470-2478.

15. Lee YHD, Kuroda R, Chan KM: Anterior Cruciate Ligament Reconstruction: A 2015 global perspective of the Magellan Society. Asia-Pacific Journal of Sports Medicine, Arthroscopy, Rehabilitation and Technology 2015, 2(4):122-128.

16. Pinczewski LA, Deehan Dj Fau - Salmon LJ, Salmon Lj Fau - Russell VJ, Russell Vj Fau - Clingeleffer A, Clingeleffer A: A five-year comparison of patellar tendon versus four-strand hamstring tendon autograft for arthroscopic reconstruction of the anterior cruciate ligament. (0363-5465 (Print)).

17. Ma CB, Francis K, Towers J, Irrgang J, Fu FH, Harner CH: Hamstring anterior cruciate ligament reconstruction: a comparison of bioabsorbable interference screw and endobutton-post fixation. Arthroscopy: The Journal of Arthroscopic \& Related Surgery 2004, 20(2):122-128. 
18. Ardern CL, Webster KE, Taylor NF, Feller JA: Return to the preinjury level of competitive sport after anterior cruciate ligament reconstruction surgery: two-thirds of patients have not returned by 12 months after surgery. The American journal of sports medicine 2011, 39(3):538-543.

19. Thomopoulos S: The role of mechanobiology in the attachment of tendon to bone. IBMS BoneKEy 2011, 8(6):271-285.

20. Sharma P, Maffulli N: Tendon Injury and Tendinopathy: Healing and Repair. The Journal of Bone \& Joint Surgery 2005, 87(1):187-202.

21. Jang KM, Lim HC, Jung WY, Moon SW, Wang JH: Efficacy and Safety of Human Umbilical Cord Blood-Derived Mesenchymal Stem Cells in Anterior Cruciate Ligament Reconstruction of a Rabbit Model: New Strategy to Enhance Tendon Graft Healing. Arthroscopy : the journal of arthroscopic \& related surgery : official publication of the Arthroscopy Association of North America and the International Arthroscopy Association 2015, 31(8):1530-1539.

22. Ju YJ, Muneta T, Yoshimura H, Koga H, Sekiya I: Synovial mesenchymal stem cells accelerate early remodeling of tendon-bone healing. Cell and tissue research 2008, 332(3):469-478.

23. Ouyang HW, Goh JC, Lee EH: Use of bone marrow stromal cells for tendon graft-to-bone healing: histological and immunohistochemical studies in a rabbit model. The American journal of sports medicine 2004, 32(2):321-327.

24. Hao ZC, Wang SZ, Zhang XJ, Lu J: Stem cell therapy: a promising biological strategy for tendon-bone healing after anterior cruciate ligament reconstruction. (1365-2184 (Electronic)).

25. Kohno T, Ishibashi Y, Tsuda E, Kusumi T, Tanaka M, Toh S: Immunohistochemical demonstration of growth factors at the tendon\&\#x2013;bone interface in anterior cruciate ligament reconstruction using a rabbit model. J Orthop Sci, 12(1):67-73.

26. Lim JK, Hui J Fau - Li L, Li L Fau - Thambyah A, Thambyah A Fau - Goh J, Goh J Fau - Lee E-H, Lee EH: Enhancement of tendon graft osteointegration using mesenchymal stem cells in a rabbit model of anterior cruciate ligament reconstruction. (1526-3231 (Electronic)).

27. Soon MY, Hassan A Fau - Hui JHP, Hui Jh Fau - Goh JCH, Goh Jc Fau - Lee EH, Lee EH: An analysis of soft tissue allograft anterior cruciate ligament reconstruction in a rabbit model: a short-term study of the use of mesenchymal stem cells to enhance tendon osteointegration. (0363-5465 (Print)).

28. Mamidi MK, Das AK, Zakaria Z, Bhonde R: Mesenchymal stromal cells for cartilage repair in osteoarthritis. (15229653 (Electronic)).

29. Afizah H, Hui JHP: Mesenchymal stem cell therapy for osteoarthritis. Journal of Clinical Orthopaedics and Trauma 2016, 7(3):177-182.

30. Silva A, Sampaio R Fau - Fernandes R, Fernandes R Fau - Pinto E, Pinto E: Is there a role for adult non-cultivated bone marrow stem cells in ACL reconstruction? (1433-7347 (Electronic)).

31. Roberts SJ, van Gastel N, Carmeliet G, Luyten FP: Uncovering the periosteum for skeletal regeneration: the stem cell that lies beneath. (1873-2763 (Electronic)).

32. Chang CH, Chen Ch Fau - Liu H-W, Liu Hw Fau - Whu S-W, Whu Sw Fau - Chen S-H, Chen Sh Fau - Tsai C-L, Tsai Cl Fau - Hsiue G-H, Hsiue GH: Bioengineered periosteal progenitor cell sheets to enhance tendon-bone healing in a bone tunnel. (2320-2890 (Electronic)).

33. Chen $\mathrm{CH}$ : Strategies to enhance tendon graft--bone healing in anterior cruciate ligament reconstruction. (2309-835X (Electronic)).

34. Chen CH, Chen WJ, Shih CH, Yang CY, Liu SJ, Lin PY: Enveloping the tendon graft with periosteum to enhance tendon-bone healing in a bone tunnel: A biomechanical and histologic study in rabbits. Arthroscopy : the journal of arthroscopic \& related surgery : official publication of the Arthroscopy Association of North America and the International Arthroscopy Association 2003, 19(3):290-296.

35. Chen CH, Chen Wj Fau - Shih C-H, Shih Ch Fau - Chou S-W, Chou SW: Arthroscopic anterior cruciate ligament reconstruction with periosteum-enveloping hamstring tendon graft. (0942-2056 (Print)).

36. Chen CH, Chang Ch Fau - Su C-I, Su Ci Fau - Wang K-C, Wang Kc Fau - Liu H-T, Liu Ht Fau - Yu C-M, Yu Cm Fau - Wong C-B, Wong Cb Fau - Wang IC, Wang IC: Arthroscopic single-bundle anterior cruciate ligament reconstruction with periosteum-enveloping hamstring tendon graft: clinical outcome at 2 to 7 years. (1526-3231 (Electronic)). 


\section{Chapter 1}

37. Mifune Y, Matsumoto T, Takayama K, Terada S, Sekiya N, Kuroda R, Kurosaka M, Fu FH, Huard J: Tendon graft revitalization using adult anterior cruciate ligament (ACL)-derived CD34+ cell sheets for ACL reconstruction. Biomaterials 2013, 34(22):5476-5487.

38. Mifune Y, Matsumoto T, Ota S, Nishimori M, Usas A, Kopf S, Kuroda R, Kurosaka M, Fu FH, Huard J: Therapeutic potential of anterior cruciate ligament derived stem cells for anterior cruciate ligament reconstruction. Cell transplantation 2012.

39. Matsumoto T, Ingham SM, Mifune Y, Osawa A, Logar A, Usas A, Kuroda R, Kurosaka M, Fu FH, Huard J: Isolation and characterization of human anterior cruciate ligament-derived vascular stem cells. Stem cells and development 2012, 21(6):859-872.

40. Asahara T, Murohara T, Sullivan A, Silver M, van der Zee R, Li T, Witzenbichler B, Schatteman G, Isner JM: Isolation of putative progenitor endothelial cells for angiogenesis. Science 1997, 275(5302):964-967.

41. Boswell SG, Cole Bj Fau - Sundman EA, Sundman Ea Fau - Karas V, Karas V Fau - Fortier LA, Fortier LA: Plateletrich plasma: a milieu of bioactive factors. (1526-3231 (Electronic)).

42. Murray MM, Spindler KP, Ballard P, Welch TP, Zurakowski D, Nanney LB: Enhanced histologic repair in a central wound in the anterior cruciate ligament with a collagen-platelet-rich plasma scaffold. Journal of orthopaedic research : official publication of the Orthopaedic Research Society 2007, 25(8):1007-1017.

43. Yoshida R, Murray MM: Peripheral blood mononuclear cells enhance the anabolic effects of platelet-rich plasma on anterior cruciate ligament fibroblasts. Journal of orthopaedic research : official publication of the Orthopaedic Research Society 2013, 31(1):29-34.

44. Vavken P, Sadoghi P, Murray MM: The effect of platelet concentrates on graft maturation and graft-bone interface healing in anterior cruciate ligament reconstruction in human patients: a systematic review of controlled trials. Arthroscopy : the journal of arthroscopic \& related surgery : official publication of the Arthroscopy Association of North America and the International Arthroscopy Association 2011, 27(11):1573-1583.

45. Andriolo L, Di Matteo B, Kon E, Filardo G, Venieri G, Marcacci M: PRP Augmentation for ACL Reconstruction. BioMed research international 2015, 2015:371746.

46. Di Matteo B, Loibl M, Andriolo L, Filardo G, Zellner J, Koch M, Angele P: Biologic agents for anterior cruciate ligament healing: A systematic review. (2218-5836 (Linking)).

47. Cenni E, Avnet S, Fotia C, Salerno M, Baldini N: Platelet-rich plasma impairs osteoclast generation from human precursors of peripheral blood. Journal of orthopaedic research : official publication of the Orthopaedic Research Society 2010, 28(6):792-797.

48. Hashimoto Y, Yoshida G, Toyoda H, Takaoka K: Generation of tendon-to-bone interface "enthesis" with use of recombinant BMP-2 in a rabbit model. Journal of orthopaedic research : official publication of the Orthopaedic Research Society 2007, 25(11):1415-1424.

49. Pan W, Wei Y, Zhou L, Li D: Comparative in vivo study of injectable biomaterials combined with BMP for enhancing tendon graft osteointegration for anterior cruciate ligament reconstruction. Journal of orthopaedic research : official publication of the Orthopaedic Research Society 2011, 29(7):1015-1021.

50. Martinek V, Latterman C, Usas A, Abramowitch S, Woo SL, Fu FH, Huard J: Enhancement of tendon-bone integration of anterior cruciate ligament grafts with bone morphogenetic protein-2 gene transfer: a histological and biomechanical study. J Bone Joint Surg Am 2002, 84-A(7):1123-1131.

51. Mihelic R, Pecina M, Jelic M, Zoricic S, Kusec V, Simic P, Bobinac D, Lah B, Legovic D, Vukicevic S: Bone morphogenetic protein-7 (osteogenic protein-1) promotes tendon graft integration in anterior cruciate ligament reconstruction in sheep. The American journal of sports medicine 2004, 32(7):1619-1625.

52. Yamazaki S, Yasuda K, Tomita F, Tohyama H, Minami A: The effect of transforming growth factor-beta1 on intraosseous healing of flexor tendon autograft replacement of anterior cruciate ligament in dogs. Arthroscopy : the journal of arthroscopic \& related surgery : official publication of the Arthroscopy Association of North America and the International Arthroscopy Association 2005, 21(9):1034-1041.

53. Leask A, Holmes A, Abraham DJ: Connective tissue growth factor: a new and important player in the pathogenesis of fibrosis. Current rheumatology reports 2002, 4(2):136-142. 
54. Yoshikawa T, Tohyama H, Katsura T, Kondo E, Kotani Y, Matsumoto H, Toyama Y, Yasuda K: Effects of local administration of vascular endothelial growth factor on mechanical characteristics of the semitendinosus tendon graft after anterior cruciate ligament reconstruction in sheep. The American journal of sports medicine 2006, 34(12):19181925.

55. Sasaki K, Kuroda R, Ishida K, Kubo S, Matsumoto T, Mifune Y, Kinoshita K, Tei K, Akisue T, Tabata Y et al: Enhancement of tendon-bone osteointegration of anterior cruciate ligament graft using granulocyte colony-stimulating factor. The American journal of sports medicine 2008, 36(8):1519-1527.

56. Nakase J, Kitaoka K Fau - Matsumoto K, Matsumoto K Fau - Tomita K, Tomita K: Facilitated tendon-bone healing by local delivery of recombinant hepatocyte growth factor in rabbits. (1526-3231 (Electronic)).

57. Weiler A, Forster C Fau - Hunt P, Hunt P Fau - Falk R, Falk R Fau - Jung T, Jung T Fau - Unterhauser FN, Unterhauser Fn Fau - Bergmann V, Bergmann V Fau - Schmidmaier G, Schmidmaier G Fau - Haas NP, Haas NP: The influence of locally applied platelet-derived growth factor-BB on free tendon graft remodeling after anterior cruciate ligament reconstruction. (0363-5465 (Print)).

58. Nin JR, Gasque GM, Azcarate AV, Beola JD, Gonzalez MH: Has platelet-rich plasma any role in anterior cruciate ligament allograft healing? Arthroscopy : the journal of arthroscopic \& related surgery : official publication of the Arthroscopy Association of North America and the International Arthroscopy Association 2009, 25(11):1206-1213.

59. Vogrin M, Rupreht M, Crnjac A, Dinevski D, Krajnc Z, Recnik G: The effect of platelet-derived growth factors on knee stability after anterior cruciate ligament reconstruction: a prospective randomized clinical study. Wiener klinische Wochenschrift 2010, 122 Suppl 2:91-95.

60. Darabos N, Haspl M, Moser C, Darabos A, Bartolek D, Groenemeyer D: Intraarticular application of autologous conditioned serum (ACS) reduces bone tunnel widening after ACL reconstructive surgery in a randomized controlled trial. Knee surgery, sports traumatology, arthroscopy : official journal of the ESSKA 2011, 19 Suppl 1:S36-46.

61. Lattermann C, Zelle BA, Whalen JD, Baltzer AW, Robbins PD, Niyibizi C, Evans CH, Fu FH: Gene transfer to the tendon-bone insertion site. Knee surgery, sports traumatology, arthroscopy : official journal of the ESSKA 2004, 12(5):510-515.

62. Dong Y, Zhang Q, Li Y, Jiang J, Chen S: Enhancement of tendon-bone healing for anterior cruciate ligament (ACL) reconstruction using bone marrow-derived mesenchymal stem cells infected with BMP-2. International journal of molecular sciences 2012, 13(10):13605-13620.

63. Li F, Jia H, Yu C: ACL reconstruction in a rabbit model using irradiated Achilles allograft seeded with mesenchymal stem cells or PDGF-B gene-transfected mesenchymal stem cells. Knee surgery, sports traumatology, arthroscopy : official journal of the ESSKA 2007, 15(10):1219-1227.

64. Madry H, Kohn D, Cucchiarini M: Direct FGF-2 gene transfer via recombinant adeno-associated virus vectors stimulates cell proliferation, collagen production, and the repair of experimental lesions in the human ACL. The American journal of sports medicine 2013, 41(1):194-202.

65. Tang JB, Chen CH, Zhou YL, McKeever C, Liu PY: Regulatory effects of introduction of an exogenous FGF2 gene on other growth factor genes in a healing tendon. Wound repair and regeneration : official publication of the Wound Healing Society [and] the European Tissue Repair Society 2014, 22(1):111-118.

66. Sundar S, Pendegrass CJ, Blunn GW: Tendon bone healing can be enhanced by demineralized bone matrix: a functional and histological study. Journal of biomedical materials research Part B, Applied biomaterials 2009, 88(1):115-122.

67. Kadonishi Y, Deie M Fau - Takata T, Takata T Fau - Ochi M, Ochi M: Acceleration of tendon-bone healing in anterior cruciate ligament reconstruction using an enamel matrix derivative in a rat model. (0301-620X (Print)).

68. Huangfu X, Zhao J: Tendon-bone healing enhancement using injectable tricalcium phosphate in a dog anterior cruciate ligament reconstruction model. Arthroscopy : the journal of arthroscopic \& related surgery : official publication of the Arthroscopy Association of North America and the International Arthroscopy Association 2007, 23(5):455-462.

69. Wen CY, Qin L Fau - Lee K-M, Lee Km Fau - Chan K-M, Chan KM: The use of brushite calcium phosphate cement for enhancement of bone-tendon integration in an anterior cruciate ligament reconstruction rabbit model. (1552-4981 (Electronic)). 


\section{Chapter 1}

70. Anderson K, Seneviratne AM, Izawa K, Atkinson BL, Potter HG, Rodeo SA: Augmentation of tendon healing in an intraarticular bone tunnel with use of a bone growth factor. The American journal of sports medicine 2001, 29(6):689698.

71. Iorio R, Di Sanzo V Fau - Vadala A, Vadala A Fau - Mazza D, Mazza D Fau - Valeo L, Valeo L Fau - Messano GA, Messano Ga Fau - Redler A, Redler A Fau - Iorio C, Iorio C Fau - Bolle G, Bolle G Fau - Conteduca F, Conteduca F Fau - Ferretti A et al: Nanohydroxyapatite-based bone graft substitute in tunnel enlargement after ACL surgery: RMN study. (1972-6007 (Electronic)).

72. Synthetic Bone Graft Substitute vs. Autologous Spongiosa in Revision Anterior Cruciate Ligament Reconstruction [https://clinicaltrials.gov/ct2/show/NCT02845141?term=synthetic+bone+graft+ACL\&rank=1]

73. O'Driscoll G, Green D, Taylor RR: Simvastatin, an HMG-coenzyme A reductase inhibitor, improves endothelial function within 1 month. Circulation 1997, 95(5):1126-1131.

74. Okura H, Asawa K, Kubo T, Taguchi H, Toda I, Yoshiyama M, Yoshikawa J, Yoshida K: Impact of statin therapy on systemic inflammation, left ventricular systolic and diastolic function and prognosis in low risk ischemic heart disease patients without history of congestive heart failure. Internal medicine (Tokyo, Japan) 2007, 46(17):1337-1343.

75. Bitto A, Minutoli L, Altavilla D, Polito F, Fiumara T, Marini H, Galeano M, Calo M, Lo Cascio P, Bonaiuto M et al: Simvastatin enhances VEGF production and ameliorates impaired wound healing in experimental diabetes. Pharmacological research 2008, 57(2):159-169.

76. Mundy G, Garrett R, Harris S, Chan J, Chen D, Rossini G, Boyce B, Zhao M, Gutierrez G: Stimulation of bone formation in vitro and in rodents by statins. Science 1999, 286(5446):1946-1949.

77. Oka S, Matsumoto T Fau - Kubo S, Kubo S Fau - Matsushita T, Matsushita T Fau - Sasaki H, Sasaki H Fau Nishizawa Y, Nishizawa Y Fau - Matsuzaki T, Matsuzaki T Fau - Saito T, Saito T Fau - Nishida K, Nishida K Fau Tabata Y, Tabata Y Fau - Kurosaka M et al: Local administration of low-dose simvastatin-conjugated gelatin hydrogel for tendon-bone healing in anterior cruciate ligament reconstruction. (1937-335X (Electronic)).

78. Lui PP, Lee YW, Mok TY, Cheuk YC, Chan KM: Alendronate reduced peri-tunnel bone loss and enhanced tendon graft to bone tunnel healing in anterior cruciate ligament reconstruction. Eur Cell Mater 2013, 25:78-96.

79. Thomopoulos S, Matsuzaki H, Zaegel M, Gelberman RH, Silva MJ: Alendronate prevents bone loss and improves tendon-to-bone repair strength in a canine model. Journal of orthopaedic research : official publication of the Orthopaedic Research Society 2007, 25(4):473-479.

80. Blaich G, Janssen B, Roth G, Salfeld J: Overview: Differentiating Issues in the Development of Macromolecules Compared with Small Molecules. In: Pharmaceutical Sciences Encyclopedia. John Wiley \& Sons, Inc.; 2010.

81. Lo KW, Ashe KM, Kan HM, Laurencin CT: The role of small molecules in musculoskeletal regeneration. Regenerative medicine 2012, 7(4):535-549.

82. Papatheodorou LK, Malizos Kn Fau - Poultsides LA, Poultsides La Fau - Hantes ME, Hantes Me Fau - Grafanaki K, Grafanaki K Fau - Giannouli S, Giannouli S Fau - Ioannou MG, Ioannou Mg Fau - Koukoulis GK, Koukoulis Gk Fau Protopappas VC, Protopappas Vc Fau - Fotiadis DI, Fotiadis Di Fau - Stathopoulos C et al: Effect of transosseous application of low-intensity ultrasound at the tendon graft-bone interface healing: gene expression and histological analysis in rabbits. (1879-291X (Electronic)).

83. Yeh WL, Lin Ss Fau - Yuan L-J, Yuan Lj Fau - Lee K-F, Lee Kf Fau - Lee MY, Lee My Fau - Ueng SWN, Ueng SW: Effects of hyperbaric oxygen treatment on tendon graft and tendon-bone integration in bone tunnel: biochemical and histological analysis in rabbits. (0736-0266 (Print)).

84. Wang CJ, Wang Fs Fau - Yang KD, Yang Kd Fau - Weng L-H, Weng Lh Fau - Sun Y-C, Sun Yc Fau - Yang Y-J, Yang YJ: The effect of shock wave treatment at the tendon-bone interface-an histomorphological and biomechanical study in rabbits. (0736-0266 (Print)). 


\section{Chapter 2}

\section{Anterior cruciate ligament- and hamstring tendon-derived cells: in vitro differential properties of cells involved in ACL reconstruction}

Ghebeş C.A., Kelder C., Schot T., Renard A.J., Pakvis D.F.M., Fernandes H.A.M., Saris D.B.F. 


\section{Abstract}

Anterior Cruciate Ligament (ACL) reconstruction involves the replacement of the torn ligament with a new graft, often a hamstring tendon (HT). Described as similar, the $A C L$ and HT have intrinsic differences related to their distinct anatomical locations. From a cellular perspective, identifying these differences represents a step forward in the search for new cues that enhance recovery after the reconstruction. The purpose of this study was to characterise the phenotype and multilineage potential of ACL- and $H T$-derived cells. ACL- and HT-derived cells were isolated from tissue harvest from patients undergoing total knee arthroplasty (TKA) or ACL reconstruction. In total, three $A C L$ and three HT donors were investigated. Cell morphology, self-renewal potential, surface marker profiling, expression of tendon/ligament-related gene markers and multilineage potential were analysed for both cell types; both had fibroblast-like morphology and low self-renewal potential. No differences in the expression of tendon/ligament related genes or a selected set of surface markers were observed between the two cell types. However, differences in their multilineage potential were observed: while ACL-derived cells showed a high potential to differentiate into chondrocytes and adipocytes, but not osteoblasts, HT-derived cells showed poor potential to form adipocytes, chondrocytes and osteoblasts. Our results demonstrated that HT-derived cells have low multilineage potential compared to ACL-derived cells, further highlighting the need for extrinsic signals to fully restore the function of the ACL upon reconstruction. 


\section{INTRODUCTION}

The ACL represents one of the major ligaments in the human knee. Located between the femur and the tibia, its function is to limit the anterior translation and rotation of the tibia with respect to the femur $[1,2]$, thereby contributing to the stability of the knee joint. Annually, more than 200,000 people report ACL injuries in the USA alone [3]. Due to poor cellularity, limited vascularization, and the intra-articular environment of the ACL [4-6], healing is frequently insufficient to restore functionality and thus surgical reconstruction is performed in $40 \%$ of patients [3]. The goal of surgical reconstruction is to restore the mechanical function of the knee and to prevent the knee joint from prolonged exposure to a pro-inflammatory environment, which would otherwise hamper joint homeostasis and, if not treated, could lead to the early development of osteoarthritis [7].

Over the last two decades, reconstruction of the ACL under arthroscopic observation has become a routine surgical procedure [8] and involves the use of autologous or allogeneic grafts and their fixation into femoral and tibial bone tunnels. In $80 \%$ of clinical applications autologous grafts are used as they do not pose the risks of disease transmission and immune rejection, associated with allogeneic grafts [9, 10]. HT represents one of the most often used autologous grafts [11, 12], with another option being the patellar tendon graft. The HT graft can restore the function of the ACL while minimizing morbidity at the harvest site, especially when compared to the patellar tendon graft. Its main disadvantage is the greater prevalence of knee instability [12]. The new graft is inserted into previously drilled femoral and tibial tunnels and fixed in place by intramedullar screws or cortical fixation systems (e.g. Endo-button ${ }^{\circledR}$ ), therefore restoring the function of the knee joint. Neither of the graft fixation methods showed significant differences in clinical outcomes [13].

Although the anatomical location and function of the HT differs from that of the ACL the HT is located on the back of the knee joint, attaching the hamstring muscle group to the tibia and thereby transmitting force from the muscle to the bone - its choice for the reconstruction of the ACL is based on its similarity in structure, biology and mechanical properties to the native ACL [14]. Moreover, harvesting the HT is not only easier but also has a low impact on functional disability after use. Studies that characterise the structure and morphology of these tissues have been previously reported and they described closely packed collagen fibres and low cellular content, with cells aligned with the fibres [14, 15]. Efforts to characterise the phenotype and functionality of these cells have been made. Both ACL and HT tissue are composed of fibroblasts/fibrocytes (ligament) and tenoblasts/tenocytes (tendon), with fibroblasts/tenoblasts being immature cells that become fibrocytes/tenocytes upon maturation. The remaining cells consists of chondrocytes at the bone attachment or insertion site (enthesis), synovial cells and vascular cells, including endothelial cells and smooth muscle cells of arterioles [16]. Recently, multipotent mesenchymal stromal cells (MSCs) have also been found to reside within the two tissues [17-20]. However, their presence does not seem to 
contribute to the repair of the tissues upon injury, as in the case of bone repair, where bone marrow-derived progenitor cells help to accelerate healing and regeneration [21, 22]. Therefore, further research is needed to better understand the behaviour of the cells derived from these two tissues, in order to harness their regenerative potential. In addition, as the original function of the HT graft changes after an ACL reconstruction, the cells residing in this tissue have to adapt to the new environment and initiate a remodelling process, ultimately restoring the interface between the grafted tissue and the bone. A thorough analysis of the cellular potential of the transplanted HT cells with respect to the original ACL cells will contribute to improve rehabilitation protocols thus reducing failure rates (currently 6-25\% of patients undergo revision surgery [23]) and accelerating the return to normal daily activities.

This study was based on the premise that differences in regenerative response may exist between the replaced and the new tissue after an ACL reconstruction, and therefore a characterisation of the two cell populations was performed in order to understand whether new cues are needed to improve the performance of the transplanted cells upon reconstruction. We hypothesised that, based on their anatomical location and mechanical function, ACL- and HT-derived cells display phenotypic and functional differences. Human ACL- and HT-derived cells were isolated from patients undergoing TKA or ACL reconstruction, respectively. Their self-renewal and multilineage potentials as well as surface marker expression profile were assessed. Additionally, the expression of a panel of genes known to be involved in tendon/ligament regeneration was analysed. A scheme of the experimental design is represented in Figure 1.

\section{MATERIALS AND METHODS}

\section{Isolation of ACL- and HT-derived cells}

Human ACL and HT samples were harvested from patients undergoing TKA or ACL reconstruction. In total, three ACLs and three HTs were harvested; patient information can be found in Table 1. The harvested tissue was washed with phosphate-buffered saline (PBS) and residual tissue was removed prior to dissection of the fascicles in 3 $\mathrm{mm}^{3}$ pieces (Figure 2A). Only the core portion of the tissue was dissected. For the isolation of cells from the tissue using the outgrowth procedure, the fragments were placed in culture flasks and grown for $8-10$ days at $37^{\circ} \mathrm{C}$ in growth medium (GM), consisting of Dulbecco's modified Eagle’s medium (DMEM; PAA Laboratories, Austria) containing 10\% fetal bovine serum (FBS; Lonza), $100 \mathrm{U} / \mathrm{ml}$ penicillin and 100 $\mathrm{mg} / \mathrm{ml}$ streptomycin (Gibco) and $0.2 \mathrm{mM}$ ascorbic acid (Sigma). During this period, the cells could migrate from the tissue into the bottom of the flask (Figure 2B). For the isolation of cells from the tissue using the collagenase digestion procedure, dissected tissue fascicles were digested overnight in $0.15 \%$ collagenase type II solution (Worthington) at $37^{\circ} \mathrm{C}$. The next day, the cells were washed with PBS and placed in culture flasks. 


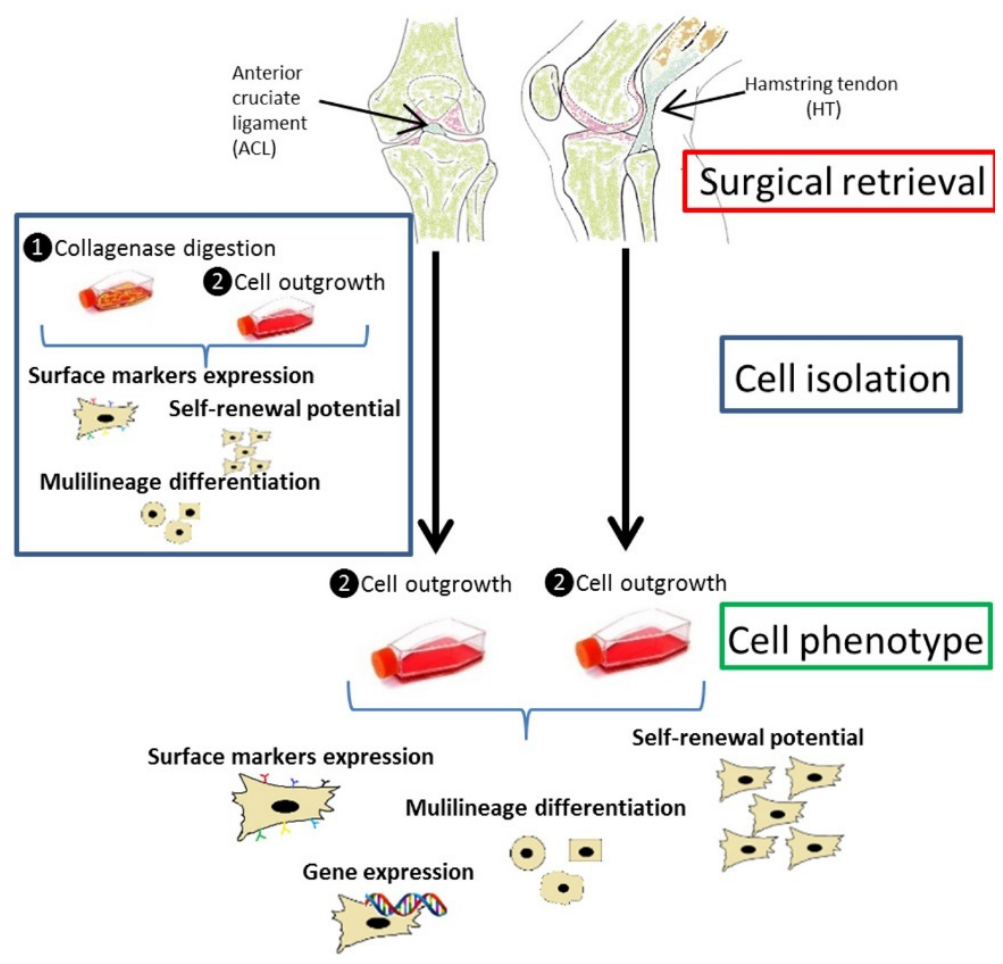

Figure 1. Schematic representation of the experimental design. Surgical retrieval of ACL and HT tissue, identifying the right cell isolation method and characterising the phenotype of the cells derived from ACL and HT.

At semi-confluence the cells were trypsinised and immediately used for the experiments and/or stored in liquid nitrogen for future use. For each experimental condition, cells between passages 2 and 3 were used, after being expanded at a density of 1,000 cells/cm² in GM.

\begin{tabular}{llll}
\hline Tissue & Gender & Age & Surgery Type \\
\hline ACL 1 & Female & 61 & TKA \\
ACL 2 & Female & 70 & TKA \\
ACL 3 & Female & 69 & TKA \\
HT 1 & Female & 24 & ACL reconstruction (healthy HT) \\
HT 2 & Female & 21 & ACL reconstruction (healthy HT) \\
HT 3 & Female & 24 & ACL reconstruction (healthy HT) \\
\hline
\end{tabular}

Table 1.Donor information of the ACL and HT samples 
The collection and anonymous use of the tissue was performed according to the medical ethical regulations and the guideline 'good use of redundant tissue for research' of the Dutch Federation of Medical Research Societies.

\section{Self-renewal potential}

One hundred ACL/HT-derived cells were seeded in a T25 flask and grown in GM for 14 days at $37^{\circ} \mathrm{C}$ and $5 \%$ CO2. The cultures were washed with PBS and fixed with $10 \%$ formalin for 15 minutes at ambient temperature, after which freshly filtered $0.5 \%$ Crystal violet solution (Sigma) was added for 5 minutes to the monolayers. Samples were rinsed with demineralized water and images were captured using an Epson Perfection V750 PRO scanner. The size of the colonies was measured using Fiji software. In addition, the functionality of the assay was routinely tested on human MSCs [24].

\section{Mineralisation}

ACL/HT-derived cells were seeded at 50,000 cells/well in 6-well plates and grown in control medium consisting of GM containing $0.01 \mathrm{M} \beta$-glycerophosphate (BGP), in mineralisation medium consisting of GM containing BGP (Sigma) and $10^{-8} \mathrm{M}$ dexamethasone (Dex), or mineralisation medium consisting of GM containing BGP and $100 \mathrm{ng} / \mathrm{ml}$ bone morphogenetic protein 2 (BMP2; Shanghai Rebone Biomaterials). Within 21-28 days, the cells were fixed in 10\% formalin for 15 minutes at ambient temperature and stained with 2\% Alizarin red (Sigma) for 2 minutes, then extensively rinsed with water. Images were captured using a Nikon brightfield microscope. In addition, the functionality of the assay was routinely tested on human MSCs.

\section{Chondrogenesis}

ACL/HT-derived cells were seeded at 250,000 cells/well (in triplicate) in a roundbottomed 96-well plate and centrifuged at 500 rcf for 5 minutes in GM. After 24 hours the medium was changed to chondrogenesis control medium (CCM), consisting of GM (without serum), $50 \mu \mathrm{g} / \mathrm{ml}$ insulin transferrin selenium (Gibco) and $40 \mu \mathrm{g} / \mathrm{ml}$ proline (Sigma), and to differentiation medium consisting of CCM containing $10 \mathrm{ng} / \mathrm{ml}$ transforming growth-factor- $\beta 3$ (TGF- $\beta 3$; R\&D Systems) and $10^{-7} \mathrm{M}$ Dex. After 28 days, the cells were fixed in $10 \%$ formalin for 15 minutes at ambient temperature and images of the pellets were taken. The size of the pellet was quantified using Fiji software. Subsequently the pellets were dehydrated in an ethanol series and embedded in paraffin. Sections $(5 \mu \mathrm{m})$ were cut and stained for sulphated glycosaminoglycans (GAGs) with Alcian blue and the nuclei were counterstained with nuclear fast red. Samples were mounted in mounting medium and images were captured with a Nikon Eclipse E600. In addition, the functionality of the assay was routinely tested on human MSCs.

As a result of positive GAG staining in ACL, but not in HT-derived cells, we decided to sequentially expand ACL-derived cells until passage 10 to further investigate their 
potential over time. For each passage, the cells were seeded at 1,250 cells $/ \mathrm{cm}^{2}$ and cultured until they reached $90 \%$ confluence, upon which they were trypsinized and either used for chondrogenic differentiation or further expanded. Images from the GAG staining of the cell pellets at passage 2, 4, 7 and 10, cultured under chondrogenic differentiation conditions, are shown (Supplementary Figure 4).

\section{Adipogenesis}

ACL/HT-derived cells were seeded at 25,000 cells/well in 24-well plates and grown in control medium, consisting of GM, or adipogenic medium, consisting of GM containing $0.2 \mathrm{mM}$ indomethacin, $0.5 \mathrm{mM}$ isobutylmetylxanthine, $10^{-6} \mathrm{M}$ Dex and $10 \mu \mathrm{g} / \mathrm{ml}$ human insulin (all from Sigma). After three weeks, the medium was discarded and the cells were washed with PBS and fixed with $10 \%$ formalin for 15 minutes at ambient temperature, following which freshly filtered Oil Red O solution (3 mg/ml in $60 \%$ isopropanol) was added to the monolayers. After 5 minutes, the samples were extensively rinsed with demineralized water and images were captured using a Nikon brightfield microscope. The area of fat droplets $\left(\mu m^{2}\right)$ was quantified using Fiji software. In addition, the functionality of the assay was routinely tested on human MSCs.

\section{Flow cytometry}

ACL/HT-derived cells were expanded in a T175 or a T300 flask until they reached confluence. The cells were trypsinised and incubated for 30 minutes in blocking buffer, consisting of $17 \%$ bovine serum albumin (BSA; Sigma) in PBS, followed by incubation with conjugated mouse anti-human antibodies for 30 minutes at $4^{\circ} \mathrm{C}$ in the dark. The samples were then washed three times with a washing buffer, consisting of $3 \%$ BSA in PBS. Expression levels of the antibodies were analysed using a FACSAria flow cytometer (BD Bioscience). For phenotypic characterisation, the following antibodies were used: CD34, HLA-DR, CD11b, CD79a, CD14, CD19, CD45, CD105, CD90, CD73, CD44, CD29, CD200, CD166, CD146, CD271, and IgG2a and IgG1 as isotype controls (all from BD Pharmingen). In addition, the functionality of antibodies was routinely tested in our laboratory on human MSCs and haematopoietic cells.

\section{RNA isolation and gene expression profile}

ACL/HT-derived cells were seeded at 10,000 cells/well in 6-well plates and grown in GM for seven days. Total RNA was isolated using the NucleoSpin RNA II isolation kit (Macherey-Nagel), per the manufacturer's instructions. RNA was collected in RNasefree water and quantitative analysis was performed using spectrophotometry (Nanodrop). First-strand cDNA was synthesised from $0.5 \mu$ g total RNA/sample, using iScript (Biorad) per the manufacturer's instructions. PCR was performed on a real-time PCR detection system (Biorad), using iQ SYBR green supermix (Biorad) for the genes $\beta 2$-microglobulin (B2M), collagen type I $\alpha 1$ (COL1A1), collagen type III $\alpha 1$ (COL3A1), cartilage oligomeric matrix protein (COMP), tenascin C (TNC), alkaline 


\begin{tabular}{|c|c|}
\hline Target Genes & Primer Sequence \\
\hline \multirow[t]{2}{*}{ COL IA1 } & 5'-GTCACCCACCGACCAAGAAACC \\
\hline & 5’-AAGTCCAGGCTGTCCAGGGATG \\
\hline \multirow[t]{2}{*}{ COL IIIA1 } & 5'-GCCAACGTCCACACCAAATT \\
\hline & 5'-AACACGCAAGGCTGTGAGACT \\
\hline \multirow[t]{2}{*}{ TNC } & 5’-TGGGCAGATTTCACGGCTG \\
\hline & 5'-TGCTCTGAGCCCGAATGTC \\
\hline \multirow[t]{2}{*}{ COMP } & 5’-GTCCGCTGTATCAACACCAG \\
\hline & 5'-GGAGTTGGGGACGCAGTTA \\
\hline \multirow[t]{2}{*}{ ALP } & 5'-ACAAGCAСТСССАСТТСАТС \\
\hline & 5'-TTCAGCTCGTACTGCATGTC \\
\hline \multirow[t]{2}{*}{ BGLAP } & 5'-GGCAGCGAGGTAGTGAAGAG \\
\hline & 5'-GATGTGGTCAGCCAACTCGT \\
\hline
\end{tabular}

Table 2. Primers used for Real-Time Polymerase Chain Reaction Analysis

phosphatase (ALP) and bone $\gamma$-carboxyglutamic acid-containing protein (BGLAP) or TaqMan Universal MasterMix for scleraxis (SCX). Primer sequences are described in Table 2. Gene expression was normalised to the reference gene B2M and fold induction calculated using the $\Delta \Delta \mathrm{C}_{\mathrm{T}}$ method.

\section{Image processing}

Images showing the capacity of ACL/HT-derived cells to form colonies were acquired using an Epson Perfection V750 PRO scanner at a resolution of $800 \times 800 \mathrm{dpi}$. The acquired images were then processed using Fiji software. The images were zoomed 100 times, followed by the selection of a rectangular region of interest representing $3.5 \times 3.5$ $\mathrm{cm}$ of the total surface area of a T25 flask. The images were then transformed to monochrome ( 8 - bit) and the brightness and contrast were adjusted in a way that allowed the visualisation of the small colonies.

Images showing the presence of fat droplets in differentiated cells were processed using Fiji software. The images were transformed to monochrome. Brightness and contrast were adjusted, similarly in test and control samples, and the fat droplets were selected and their area measured.

Images showing the size of the cell pellets cultured under chondrogenic conditions were quantified using Fiji software. The images were transformed to monochrome, the scale was set from pixel to $\mu \mathrm{m}$. The threshold was adjusted so that only the pellet area was selected and measured.

\section{Statistical analysis}

Statistical analysis was performed using Graphpad Prism 6 software. Unpaired Student's $t$-test was used to compare the data when two groups were analysed. $\mathrm{p} \leq 0.05$ indicates a statistically significant difference. Results are shown as mean \pm standard deviation (SD). 


\section{RESULtS}

\section{Cell isolation procedure: outgrowth vs. collagenase tissue dissociation}

ACL-derived cells were isolated either by cell outgrowth or by collagenase tissue dissociation, and their cell phenotype was compared based on self-renewal, multilineage differentiation potential and surface marker expression. In total, three donors were used. We found that both cell isolation methods showed similar self-renewal potential, with colonies similar in size and shape (Supplementary Figure 1A,B) and similar multilineage potential (Supplementary Figure 1C-P). We found no mineralisation potential in the presence of Dex (Supplementary Figure 1C,F) but positive GAG staining in the chondrogenic pellets (Supplementary Figure 1I,K) and similar amounts of fat droplets formation (Supplementary Figure 1M,N).

Positive cell surface markers, such as CD105 and CD44, were slightly but not significantly higher in the cells isolated by collagenase tissue dissociation compared to cell migration (Supplementary Figure 2).

Based on these findings, we decided to further isolate the cells using the cell migration method, as no significant differences were observed between the two cell isolation methods and as it is less invasive for the cells because no chemical additives are used.

\section{Isolation and characterisation of ACL- and HT-derived cells}

Upon tissue dissection, migration of ACL- and HT-derived cells occurred within 7-10 days. During this period, the medium was changed once in order to minimise the disturbance and potential loss of the adherent cells. We found that cells migrated from the tissue threads and attached to the bottom of the tissue culture flask (Figure 2B). Moreover, we saw that cell colonies were larger underneath the tissue threads than in other isolated spots in the flask (Figure 2B,C).

The morphology of the obtained cells was mostly spindle-shaped and fibroblast-like. Nevertheless, some elongated or large flattened and star-shaped cells were also present, indicating a heterogeneous cell population (Figure 2C). Throughout the culture period, the afore-mentioned heterogeneous population of ACL- and HT-derived cells evolved to a more homogenous fibroblast-like population, suggesting an enrichment of certain cell populations to the detriment of others (Figure 2C-E).

\section{Self-renewal potential (CFU-F assay)}

ACL- and HT-derived cells were seeded at low density in order to analyse their selfrenewal potential in vitro, as measured by the capacity to form individual colonies. After 14 days in culture, small colonies were observed in both cell types, with mean colony-forming unit (CFU) diameters of $0.14 \pm 0.03$ and $0.04 \pm 0.01 \mathrm{~cm}$ for ACL- 


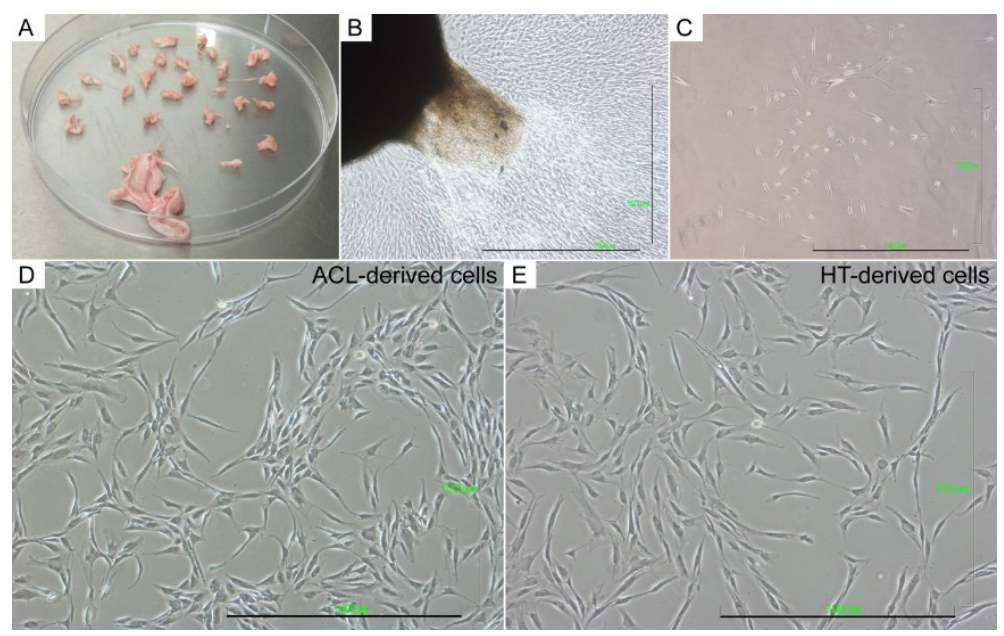

Figure 2. Isolation and morphological characterisation of ACL-and HT-derived cells. Harvested HT tissue was dissected in small fragments (A) and placed in culture flasks. HTderived cell migration from the tissue (black mass) to the bottom of the flask (B) and the obtained heterogeneous cell population (C) at passage PO. ACL-derived (D) and HTderived cells (E) at P2 and P3, respectively; in both cases the cells show a fibroblastic-like structure. Scale bar indicates 1,000 $\mu \mathrm{m}$.

derived and HT-derived cells, respectively (Figure 3). Moreover, in the case of HTderived cells, the colonies obtained showed irregular boundaries, rather than the typical round boundaries characteristic of bone marrow derived MSCs [25]. In contrast, ACLderived cells formed colonies with well-defined borders, similar to the ones previously reported for MSCs. Our statement was based on visual observations.

\section{Osteogenesis}

ACL- and HT-derived cells cultured in osteogenic differentiation medium did not stain positive for calcium deposits, as measured by Alizarin red staining, with the exception of cells from one HT-derived donor (Figure 4D). To further confirm the reproducibility in calcium deposition for this donor, we cultured the cells derived from the same donor in osteogenic induction medium and observed the same phenomena (Supplementary Figure 5A). In addition to this, for the same donor, we examined a panel of osteogenicrelated markers and their expression after 14 days of culture in osteogenic induction medium. We found no statistically significant differences in collagen IA1, ALP and BGLAP expression in the osteogenically induced group compared to the control (Supplementary Figure 5B), although a trend towards higher expression for ALP and BGLAP was noticeable. The addition of BMP-2 to the medium did not induce calcium deposition in either ACL- or in HT-derived cells (Figure 4B, E). 


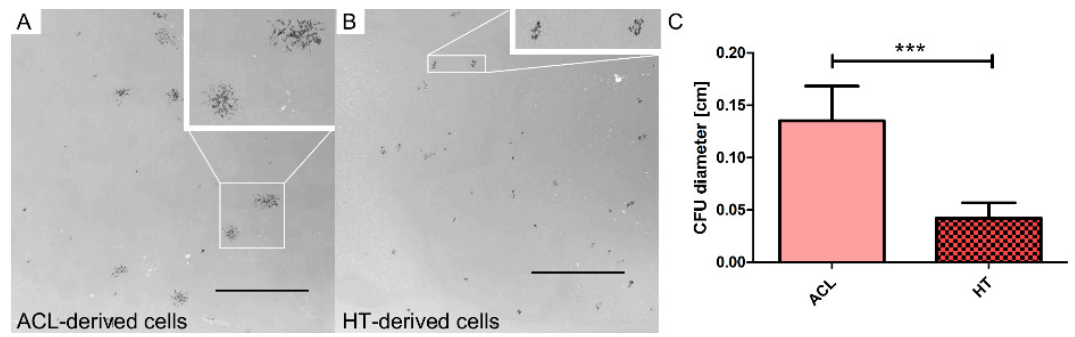

Figure 3. Crystal violet staining of ACL- (A) and HT-derived cells (B). To investigate their self-renewal potential, cells were seeded at clonal density (100 cells/25 cm2). (C) Quantification of colony size by measuring the diameter (cm); unpaired Student's t-test of the quantified colony size was performed; ${ }^{* * *} P<0.001$. Scale bar represents $1 \mathrm{~cm}$.

\section{Chondrogenesis}

Pellet cultures were established for ACL- and HT-derived cells and grown for 28 days in control or chondrogenic induction medium. After 28 days of culture, ACL-derived cell pellets cultured under chondrogenic conditions were greater in size than HT-derived cell pellets (Supplementary Figure 3), probably resulting from an increase in extracellular matrix (ECM) deposition. The increase in ECM production was confirmed by Alcian blue staining, which revealed a uniform staining of GAGs in ACL-derived cells (Figure 4G), in contrast to HT-derived cells, where GAG staining was absent (Figure 4I). Despite the positive staining, it was noteworthy that the morphology of the obtained cartilage was more consistent with fibroblast-like cartilage than with the typical round morphology of a chondron. Interestingly, extensive in vitro culture did not hamper the chondrogenic potential of ACL-derived cells, as demonstrated by the presence of Alcian Blue-positive cells up to passage 10 (Supplementary Figure 4). Cells cultured under control conditions stained negative in both cases (Figure $4 \mathrm{H}, \mathrm{J}$ ).

\section{Adipogenesis}

The capacity of ACL- and HT-derived cells to form adipocytes upon exposure to induction medium was analysed, and we found a statistically significant difference between ACL- and HT-derived cells (Figure 4K, L). The formation of fat droplets was five times higher in ACL- than in HT-derived cells (Figure 4N). Moreover, the results were not a result of contamination of the sample with adipocytes, since the control samples stained negative for adipogenesis (Figure 4M). 


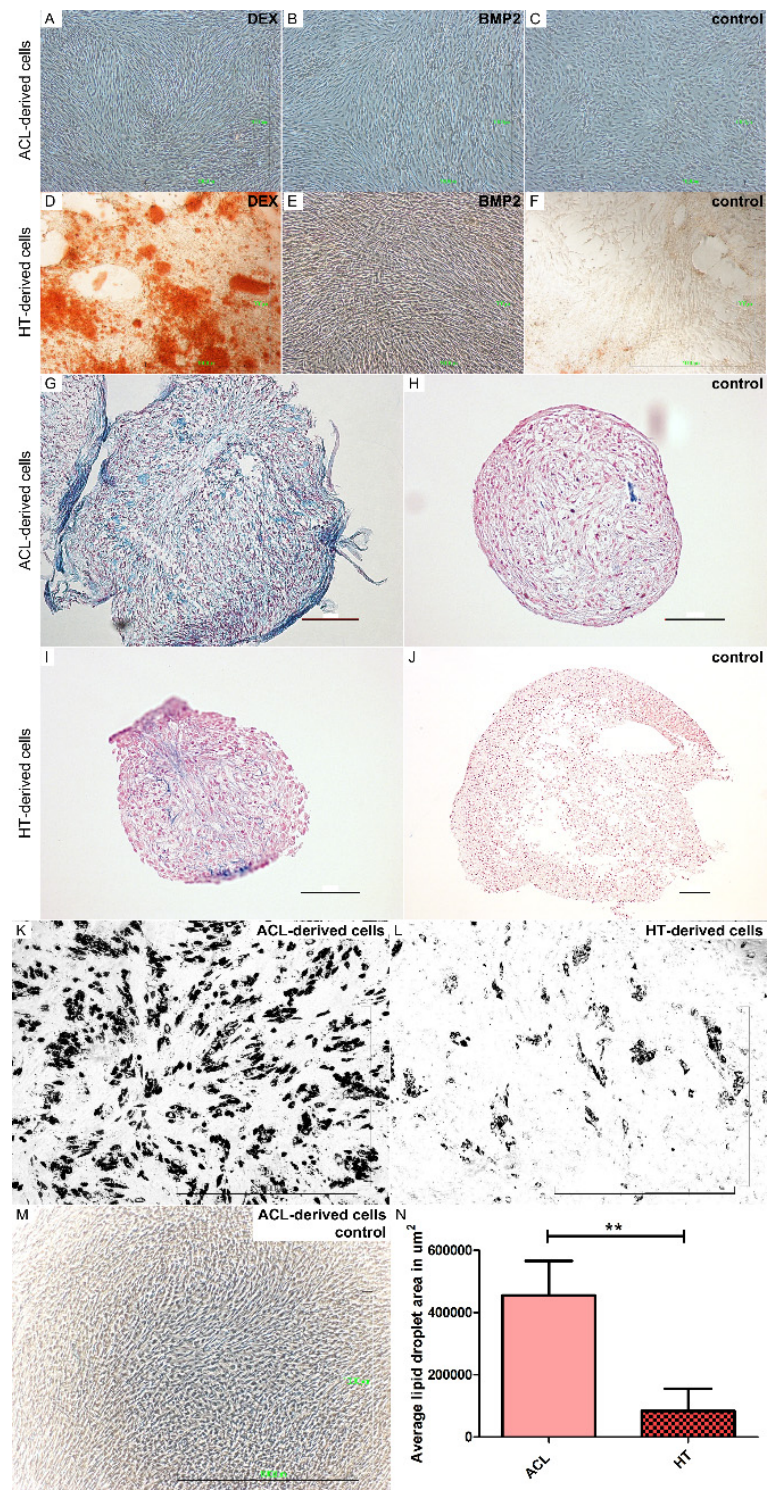

Figure 4. Multilineage potential of ACL-and HT-derived cells. Alizarin red staining of calcium nodules after osteogenic induction of ACL-derived (A-C) and HT-derived cells (DF); from left to the right, cells were exposed either to $10^{-8} \mathrm{M} \mathrm{Dex,} 100 \mathrm{ng} / \mathrm{ml} \mathrm{BMP} 2$ or 0.01 $M B G P$ alone. Osteogenic differentiation of ACL/HT-derived cells occurred in only one HT donor, as shown in (D); scale bar represents 1,000 $\mu \mathrm{m}$. Alcian blue staining of GAG in ACL-derived $(G, H)$ and $H T$-derived cell pellets $(I, J)$ after chondrogenic induction $(G, I)$ and in the control $(H, J)$; scale bar represents $100 \mu \mathrm{m}$. Oil Red O staining of fat droplets in ACL-derived (K) and HT-derived cells (L) after adipogenic induction. (M) ACL-derived cells cultured in growth media (control) show no fat droplets formation after staining with Oil Red O; the image is representative also for HT-derived cells. (N) Quantification of fat droplets by measuring their area $\left(\mu \mathrm{m}^{2}\right)$; unpaired Student's t-test of the quantified fat droplets was performed; ** $P<0.01$. Scale bar represents 1,000 $\mu \mathrm{m}$. 


\section{Gene expression profile (RT-PCR)}

A panel of tendon/ligament-related genes was analysed in order to compare the potential of ACL- and HT-derived cells to differentiate into tendon/ligaments. To do so, we measured the expression of COL1A1, COL3A1, Scleraxis, TNC and COMP (Figure $5 A)$. We found no statistically significant differences between the expression of these markers in the two cell types (for each marker the average over each cell population was calculated and compared) (Figure 5B).
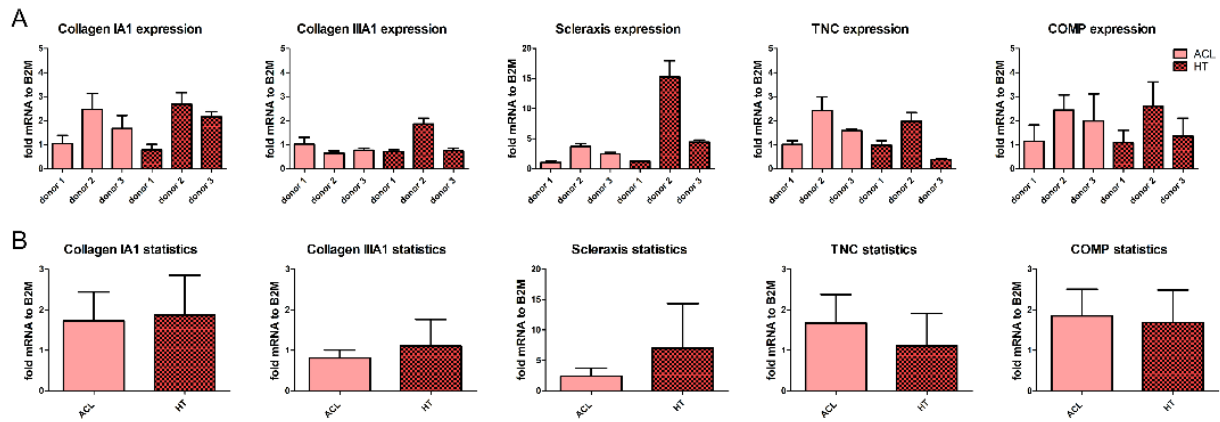

Figure 5. mRNA expression of ligament/tendon-related markers in ACL-and HT-derived cells (A); ACL donor 1 represents the base line. (B) No statistically significant differences between the ACL- and HT-derived cells were observed; unpaired Student's t-test per gene and on the averaged expression per cell type was performed.

\section{Expression of surface markers}

The analyses of surface markers in ACL- and HT-derived cells showed that, in both cases, a substantial portion of cells expressed CD90 (60 - 70\%) marker, whereas a small number expressed CD44 (20\%) and CD73 (7 - 9\%) and almost no cells expressed CD105 (2 - 3\%); see Figure 6. On average, a higher expression of these markers, identified in a large variety of stromal cells belonging to different tissues, was found in HT- than in ACL- derived cells. The remaining markers for hematopoietic stem cells (CD34, CD45, CD11b), pericytes (CD146), B or T cells (CD79a, HLA-DR, CD166, CD200, CD19) and others (CD14, CD29, CD271) were not expressed in either of the two cell types.

\section{Discussion}

A key component in the successful regeneration of a reconstructed ACL is the understanding of the differences and similarities between the replaced and the new tissue. Fibroblasts/tenoblasts isolated from ligaments/tendons have been studied separately for musculoskeletal tissue regeneration $[13,26]$. Their poor healing capacity increased the interest of using human MSCs isolated from various tissues to improve the healing of these tissues. Although some studies showed that cells isolated from 

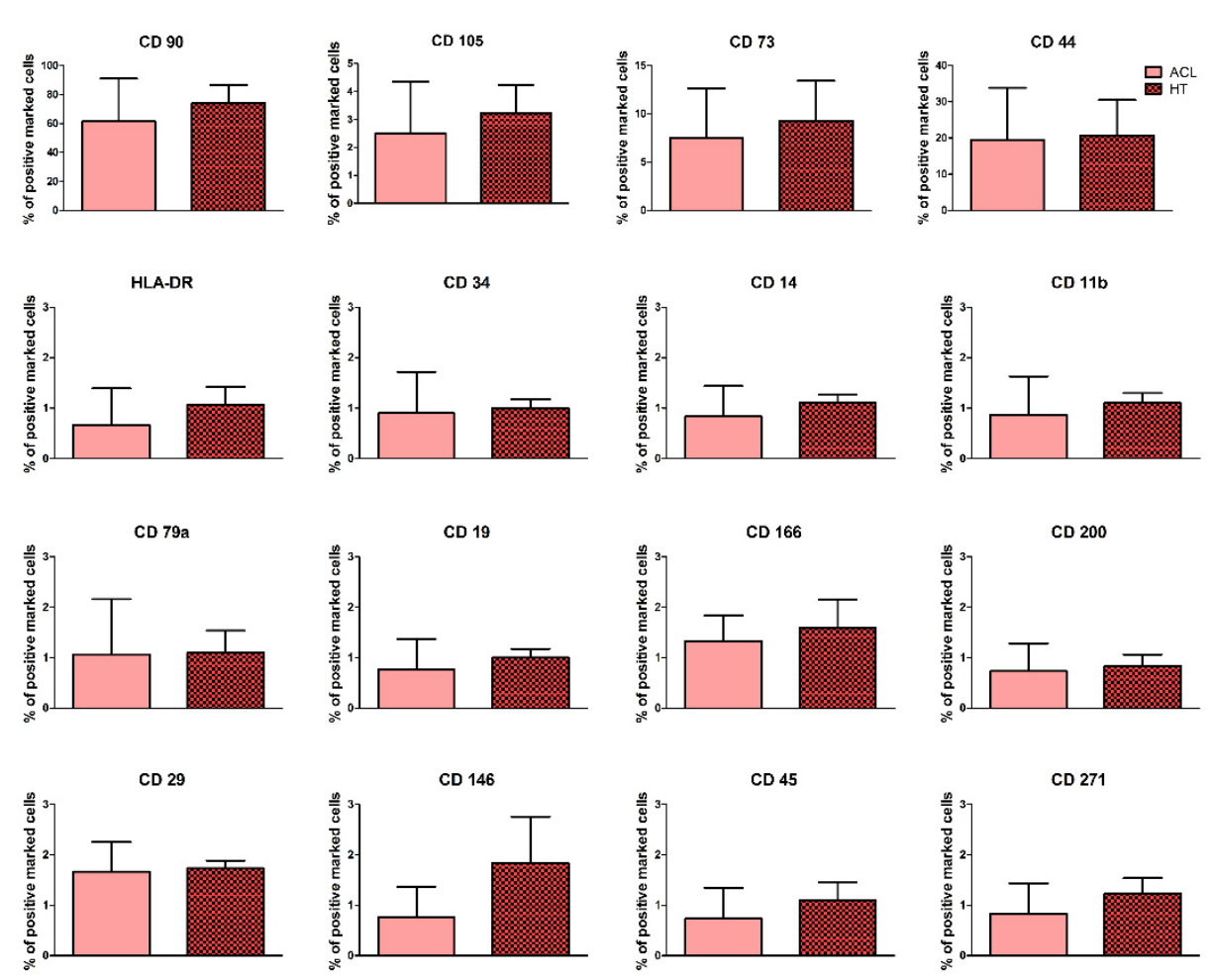

Figure 6. Surface marker expression (in percentage) of ACL-and HT-derived cells, represented as a bar-plot; each bar stands for percentage of surface marker found on the cells of the different donors corresponding to the individual cell population. Selected sets of cell surface markers expressed positive on multipotent MSCs (A-D), expressed negative on multipotent MSCs (E-J) and other surface markers (L-Q); no statistically significant differences were found between the two cell populations (unpaired Student's t-test was performed).

ligaments/tendons share similar properties with hMSCs [20, 27], their low number is insufficient for tissue regeneration without prior in vitro expansion.

In this study we analysed the phenotype of ACL- and HT-derived cells. Due to the fact that ACL and HT could not be harvested from the same patient, we performed the experiments with tissues isolated from different donors, and hence donor variation should be accounted for when critically analysing the present results. To obtain intact ACL tissue, we performed the collection during TKA, whereas the HT tissue was collected during ACL reconstruction (the ACL was totally torn, and therefore could not be retrieved for analysis). The age of the patients corresponded with the surgical procedure, with TKA performed predominantly in older patients [28] (in this study the average age was 70 years), whereas ACL reconstruction was performed in young and active patients (average age 23 years). Differences in age between the donors may influence the phenotypic outcome for the different cell types, as it has been shown that there is a decline in tissue regeneration potential with age [29]. Our results showed that 
ACL- and HT-derived cells have a similar morphology, consistent with previous reports indicating the presence of spindle and fibroblast-like cells [30, 31]. In contrast, the selfrenewal potential and the multilineage potential differed between the two cell types. Self-renewal potential, as usually defined for bone marrow MSCs, is absent in both cell types, as no colonies $>2.5 \mathrm{~mm}$ were formed [25]. Nevertheless, the size of colonies formed by the HT-derived cells was significantly lower than in the case of ACL-derived cells. These findings differ from other studies, where ACL- and HT-derived cells showed a $20-40 \%$ potential to form colonies [17, 20], defined by the presence of colonies $>2.5 \mathrm{~mm}$. The differences in performance can be ascribed to differences in tissue collection or in vitro culture conditions.

Regarding multilineage potential, our results showed that, although ACL- and HTderived cells had a low potential to differentiate into the osteogenic lineage, they clearly differed in their adipogenic and chondrogenic potential, with HT-derived cells showing limited potential to differentiate into both lineages. In addition, we showed that the chondrogenic potential of the ACL-derived cells was maintained over time, suggesting that, upon injury, a prochondrogenic remodelling process may occur, leading to functional differences between the remodelled and the original tissue. We believe that ACL-derived cells show chondrogenic and adipogenic potential due to their location in the diarthrodial joint capsule, where other tissues, such as cartilage, synovial membrane, meniscus and intrapatellar fat pad, are bathed in the synovial fluid [32]. Potentially, during development and maturation, the intercellular communication between the ACLderived cells and the cells residing in the aforementioned tissues might explain the propensity of ACL-derived cells to differentiate towards chondrocytes and/or adipocytes when the right stimuli are applied. Contrariwise, HT-derived cells do not share the same anatomical neighbours as ACL-derived cells, hence they may lack the inherent capacity to respond to chondrogenic or adipogenic stimuli. Despite the differential properties of ACL-derived cells, this does not explain their poor healing capacity. Perhaps, the hostile intra-articular environment toward healing of the injured ACL $[33,34]$, such as alterations in the post-injury inflammatory response and cell metabolism, intrinsic cell deficiencies, different vascular environments and load-bearing characteristics, might explain this conflict. We believe that these absent cues, among other biological and mechanical factors [35], might also have an important contribution to the delay in formation of a properly functioning enthesis. To better mimic the transition zone upon reconstruction of the native ACL by the HT, we believe that external help is needed. Co-delivery of growth factors such as TGF $\beta-1$ [36] or rhBMP-2 [37]; chemical and biological agents such as matrix metalloproteinases (MMPs) inhibitors [38]; multipotent autologous cells [39] or biomaterials functionalised with extra cues, such as hydroxyapatite [40], have already been shown to have a beneficial effect in accelerating healing between the tendon graft and the bone.

Here, we showed that the cells derived from one HT sample had the potential to differentiate towards the osteogenic lineage and, by doing so, will potentially facilitate the integration of the soft tissue into the bone. As mentioned before, a larger number of donors should be tested and experimental designs, including functional analysis in vitro 
and clinical outcomes in vivo, should be considered in future studies. The similar gene expression profile and the similar expression of a panel of cell surface markers showed that both cell types share common biological properties. The fact that we did not observe differences in the expression of genes involved in matrix production (COL1A1 and COL3A1) [41], cell fate (SCX) [42], cell growth, division and cartilage turnover (COMP) or cell migration and collagen assembly (TNC) [43], and furthermore the similarities in surface markers, also confirm the gene expression data, suggesting that the HT is a good candidate to replace the native ACL. Interestingly, we also observed that, although the cells derived from the two tissues showed similar expression of a panel of surface markers, their differentiation potential is different. Studies have shown that the expression of certain surface markers correlates with the potential to differentiate towards a certain lineage, suggesting that surface expression profiles can be used to preselect cells with a specific lineage potential [44, 45]. Herein, given the similar expression of the surface markers tested, the differentiation potential should have been similar. Notwithstanding, we believe that the differences are likely related to intrinsic differences in the tissues used (ACL vs. hamstring), the respective milieux and the heterogeneous nature of the obtained cell populations. The fact that HT-derived cells show limited multilineage potential suggests that accessory cell types or biological cues might be needed to maintain the transplanted tissue upon reconstruction. A solution for this could be the co-delivery of hMSCs during the ACL reconstruction, or their recruitment from the tunnels drilled during the reconstruction procedure.

Based on these observations, we propose that the intrinsic properties of ACL-derived cells can be, to a certain extent, replaced by HT-derived cells. The search for new molecules capable of modulating and reducing differences between the two cell types can help improve clinical outcome and accelerate rehabilitation.

Finally, we would like to emphasise that the findings obtained in this study should be used with caution, due to donor/age variation, the small number of donors tested, differences in cell response between the two-dimensional (2D) and the threedimensional (3D) environment and absence of mechanical loading present in situ. We showed that ACL-derived cells from older donors have chondrogenic and adipogenic properties, while HT-derived cells from young donors did not. With that in mind, we assume that younger donors in the age range comparable to the HT donors would potentially show much better performance than what we have shown in this study with older ACL donors, as it is well known that the regenerative capacities of multiple cell types diminish with age [29]. Regarding donor variation, we believe that the high reproducibility of the properties (with exception of mineralisation potential) in all donors with respect to their cell type accentuates the credibility that what we found is tissue specific rather than donor specific. As regarding donor number, three samples are rather insufficient to perform a robust statistical analysis but are sufficient to offer indicative information. The choice of using the $2 \mathrm{D}$ in detriment to the $3 \mathrm{D}$ system, and additionally ruling out the biomechanical role, was based on our purpose to understand the basic biological mechanism that underlie the differences in cellular functions 
between the two tissue types. This 2D model might not faithfully capture the physiological behaviour of cells in vivo but is suitable to address our research question.

\section{ABBREVIATIONS}

Anterior Cruciate Ligament (ACL); hamstring tendon (HT); total knee arthroplasty (TKA); colony-forming unit (CFU); mesenchymal stromal cells (MSCs); phosphate-buffered saline (PBS); growth medium (GM); $\beta$ glycerophosphate (BGP); dexamethasone (Dex); bone morphogenetic protein 2 (BMP2); chondrogenesis control medium (CCM); transforming growth-factor- $\beta 3$ (TGF- $\beta 3$ ); glycosaminoglycans (GAGs); bovine serum albumin (BSA); $\beta 2$-microglobulin (B2M); collagen type I $\alpha 1$ (COL1A1); collagen type III $\alpha 1$ (COL3A1); cartilage oligomeric matrix protein (COMP); tenascin C (TNC); alkaline phosphatase (ALP); bone $\gamma$-carboxyglutamic acid-containing protein (BGLAP); scleraxis (SCX); standard deviation (SD). 


\section{SUPPLEMENTARY FIGURES}
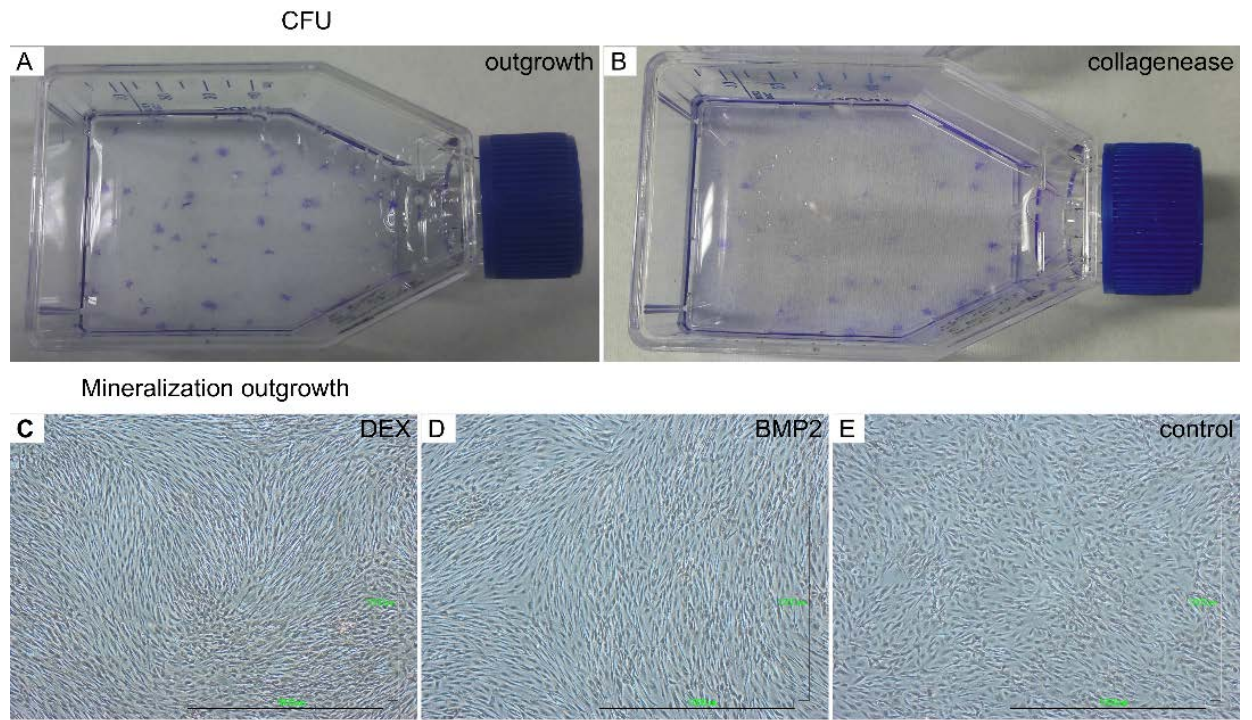

Mineralization collagenease
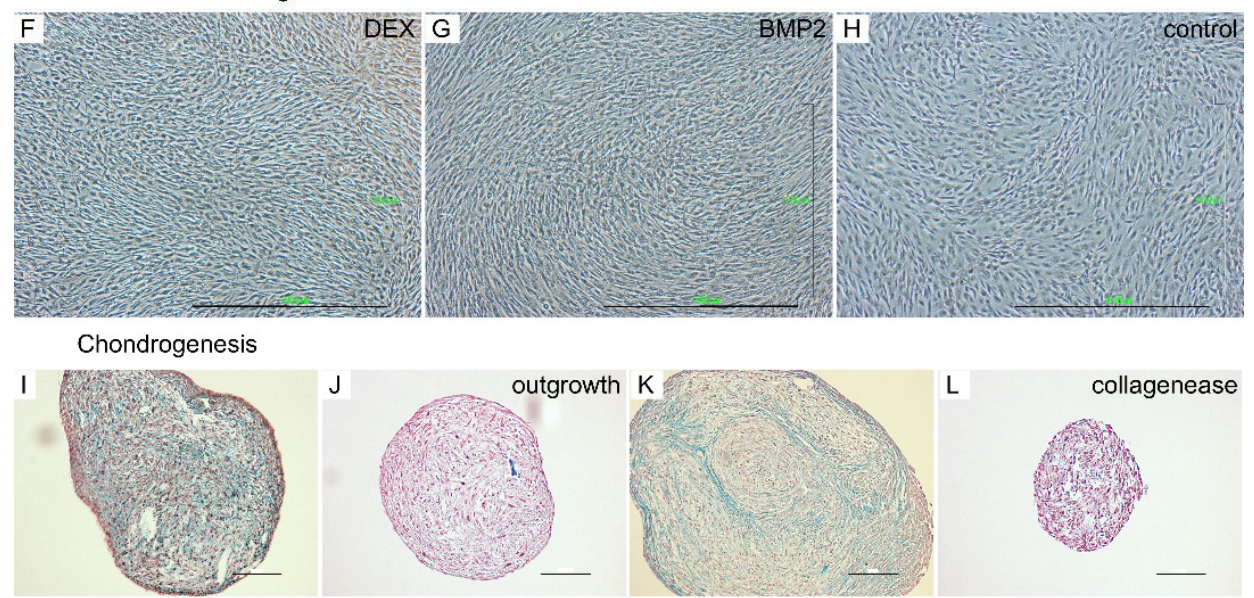

L collagenease

Adipogenesis
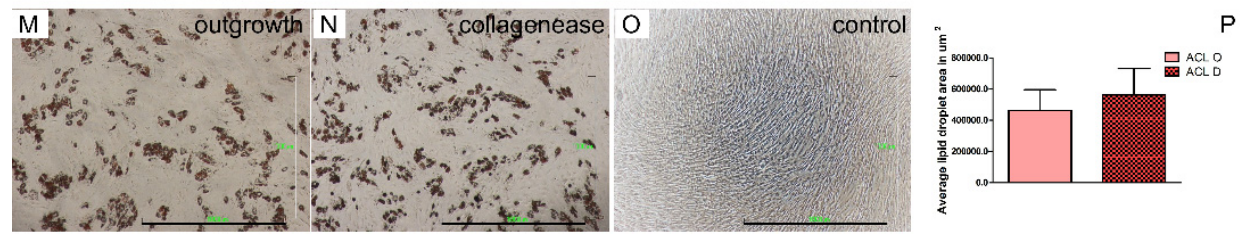
$\leftarrow \quad$ Supplementary Figure 1. Phenotype characterisation of ACL-derived cells isolated by either tissue collagenase digestion or cell outgrowth. Crystal violet staining showing colony forming unit potential of cells isolated by cell outgrowth (A) or tissue collagenase digestion (B). Alizarin red staining of outgrowth isolated cells after osteogenic induction by Dex (C) or BMP2 (D) and control (E); and tissue collagenase digested isolated cells after osteogenic induction by Dex (F) or BMP2 (G) and control $(H)$. Scale bar represents 1,000 $\mu \mathrm{m}$. Alcian blue staining of the chondrocenic induced cell pellet and control of outgrowth cells $(I, J)$ and cells isolated by tissue collagenase digestion $(K, L)$. Scale bar represents 100 $\mu \mathrm{m}$. Oil Red $\mathrm{O}$ staining of fat droplets in outgrowth cells (M) and cells isolated by tissue collagenase digestions (N) after adipogenic induction. (O) Cells isolated by tissue collagenase digestions in control media, which is representative also for cell outgrowth. $(P)$ Quantification of lipid droplets area. Scale bar represents 1,000 $\mathrm{\mu m}$.
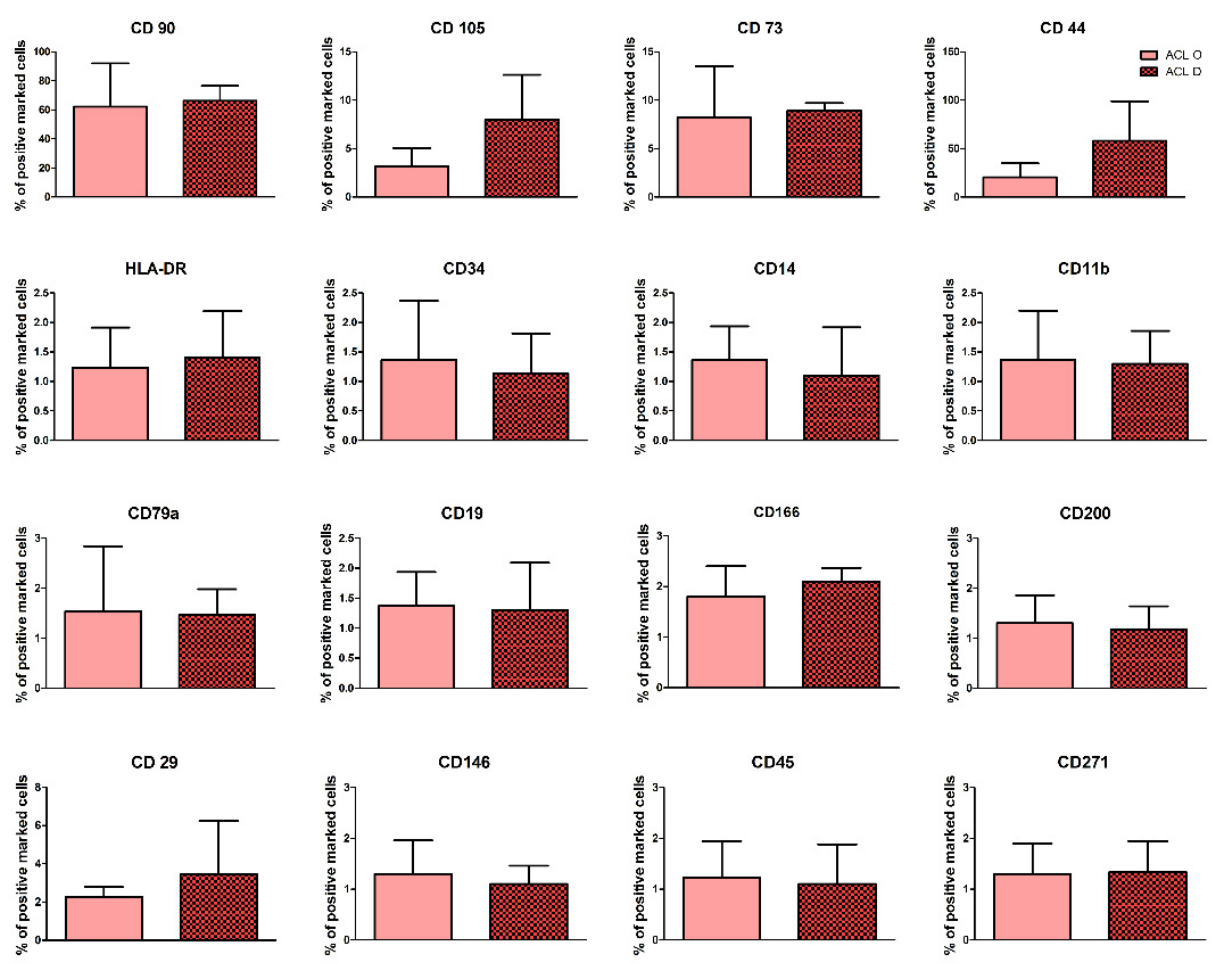

Supplementary Figure 2. Surface marker expression (in percentage) of ACL-derived cells isolated by either cell outgrowth or tissue collagenase digestion, represented as a bar-plot. No statistically significant differences were found between the two cell populations (Unpaired Student t-test was performed). 


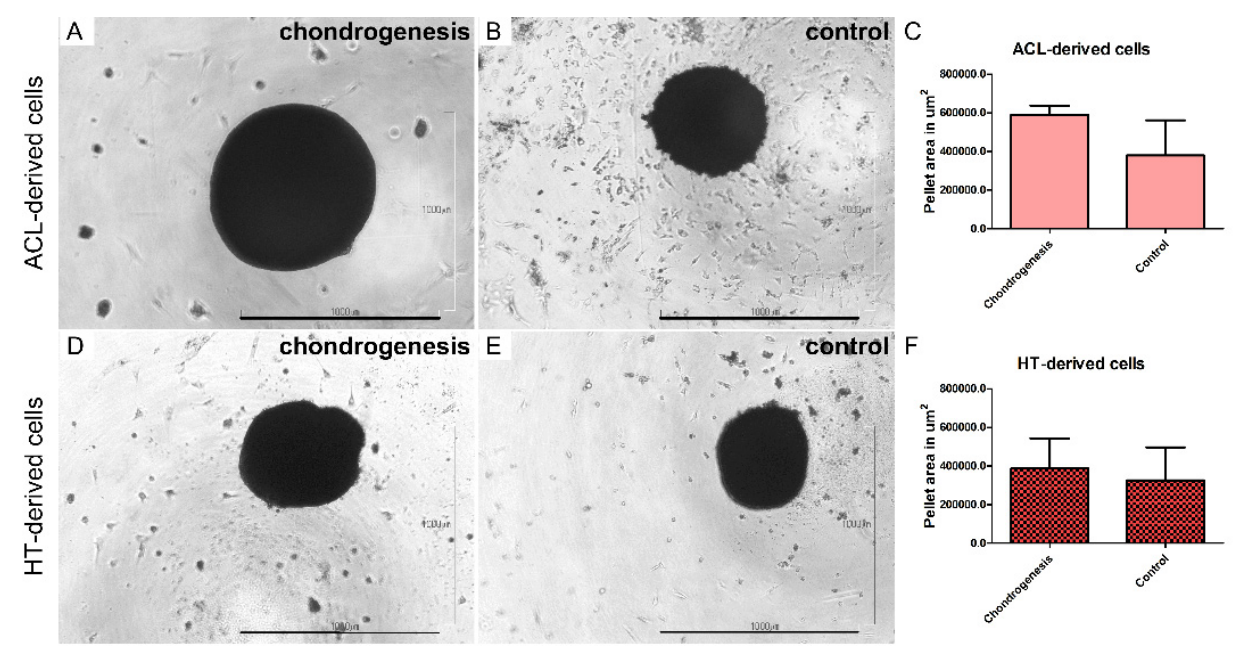

Supplementary Figure 3. Chondrogenic pellets of ACL-derived cells cultured under chondrogenic induction media (A) or basic media (B) and HT-derived cells cultured under chondrogenic induction media (D) or basic media (E). Quantification of the size of the cell pellet from ACL-derived cells $(C)$ and from HT-derived cells $(F)$.Scale bar represents 1,000 $\mu \mathrm{m}$.
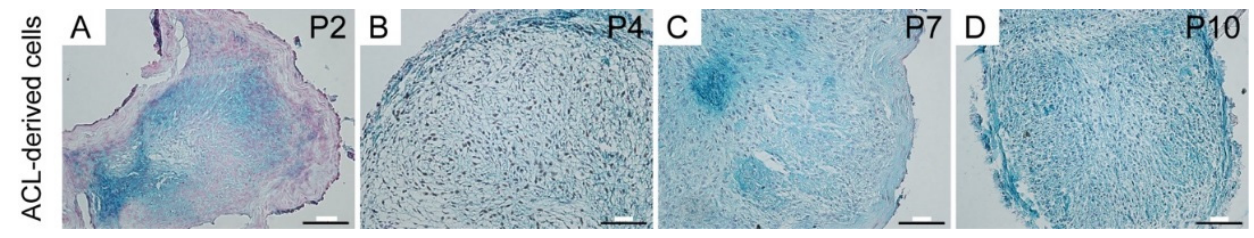

Supplementary Figure 4. Alcian blue staining of GAG in ACL-derived cell pellets. The cells were expanded in vitro and cultured in the presence of chondrogenic induction media at different passages as follow: (A) passage 2, (B) passage 4, (C) passage 7 and (D) passage 10. Scale bar represents $100 \mu \mathrm{m}$.
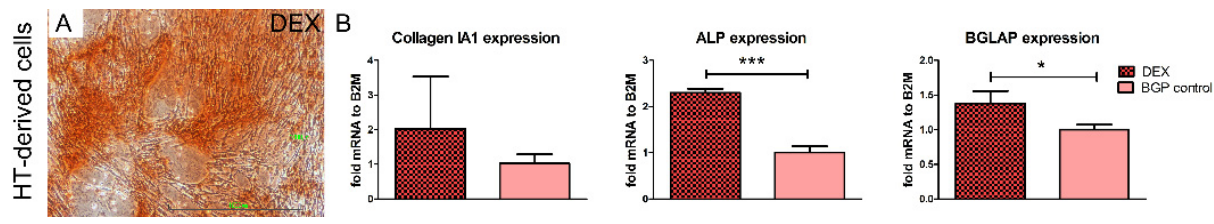

Supplementary Figure 5. Alizarin red staining of HT-derived cells showing the reproducibility of this donor to stain positive for calcium deposits (A). Scale bar represents $1,000 \mu \mathrm{m}$. Expression of osteogenic related gene markers after exposing the cells for 14 days to osteogenic induction media (DEX) or basic media (BGP). 


\section{REFERENCES}

1. Morrison JB: The mechanics of the knee joint in relation to normal walking. Journal of Biomechanics 1970, 3(1):51-61.

2. Levine JW, Kiapour AM, Quatman CE, Wordeman SC, Goel VK, Hewett TE, Demetropoulos CK: Clinically relevant injury patterns after an anterior cruciate ligament injury provide insight into injury mechanisms. The American journal of sports medicine 2013, 41(2):385-395.

3. Griffin LY, Albohm MJ, Arendt EA, Bahr R, Beynnon BD, Demaio M, Dick RW, Engebretsen L, Garrett WE, Jr., Hannafin JA et al: Understanding and preventing noncontact anterior cruciate ligament injuries: a review of the Hunt Valley II meeting, January 2005. The American journal of sports medicine 2006, 34(9):1512-1532.

4. Barrack R, Buckley S, Bruckner J, Kneisl J, Alexander A: Partial versus complete acute anterior cruciate ligament tears. The results of nonoperative treatment. Journal of Bone \& Joint Surgery, British Volume 1990, 72-B(4):622-624.

5. Maletius W, Messner K: Eighteen- to Twenty-four-Year Follow-up After Complete Rupture of the Anterior Cruciate Ligament. The American journal of sports medicine 1999, 27(6):711-717.

6. Murray MM, Fleming BC: Biology of anterior cruciate ligament injury and repair: Kappa delta ann doner vaughn award paper 2013. Journal of orthopaedic research : official publication of the Orthopaedic Research Society 2013, 31(10):1501-1506.

7. Jackson DW, Heinrich JT, Simon TM: Biologic and synthetic implants to replace the anterior cruciate ligament. Arthroscopy : the journal of arthroscopic \& related surgery : official publication of the Arthroscopy Association of North America and the International Arthroscopy Association 1994, 10(4):442-452.

8. Woo SL-Y, Vogrin TM, Abramowitch SD: Healing and Repair of Ligament Injuries in the Knee. Journal of the American Academy of Orthopaedic Surgeons 2000, 8(6):364-372.

9. Vyas D, Rabuck SJ, Harner CD: Allograft anterior cruciate ligament reconstruction: indications, techniques, and outcomes. The Journal of orthopaedic and sports physical therapy 2012, 42(3):196-207.

10. Clark JC, Rueff DE, Indelicato PA, Moser M: Primary ACL Reconstruction Using Allograft Tissue. Clinics in Sports Medicine 2009, 28(2):223-244.

11. Zhu W, Wang D, Han Y, Zhang N, Zeng Y: Anterior cruciate ligament (ACL) autograft reconstruction with hamstring tendons: clinical research among three rehabilitation procedures. European journal of orthopaedic surgery \& traumatology : orthopedie traumatologie 2012.

12. Biau DJ, Katsahian S, Kartus J, Harilainen A, Feller JA, Sajovic M, Ejerhed L, Zaffagnini S, Röpke M, Nizard R: Patellar Tendon Versus Hamstring Tendon Autografts for Reconstructing the Anterior Cruciate Ligament: A MetaAnalysis Based on Individual Patient Data. The American journal of sports medicine 2009, 37(12):2470-2478.

13. Ma CB, Francis K, Towers J, Irrgang J, Fu FH, Harner CH: Hamstring anterior cruciate ligament reconstruction: a comparison of bioabsorbable interference screw and endobutton-post fixation. Arthroscopy: The Journal of Arthroscopic \& Related Surgery 2004, 20(2):122-128.

14. Zhu J, Zhang X, Ma Y, Zhou C, Ao y: Ultrastructural and Morphological Characteristics of Human Anterior Cruciate Ligament and Hamstring Tendons. The Anatomical Record: Advances in Integrative Anatomy and Evolutionary Biology 2012, 295(9):1430-1436.

15. Kannus P: Structure of the tendon connective tissue. Scandinavian journal of medicine \& science in sports 2000, 10(6):312-320.

16. Hoffmann A, Gross G: Tendon and ligament engineering in the adult organism: mesenchymal stem cells and genetherapeutic approaches. International orthopaedics 2007, 31(6):791-797.

17. Ruzzini L, Abbruzzese F, Rainer A, Longo UG, Trombetta M, Maffulli N, Denaro V: Characterization of age-related changes of tendon stem cells from adult human tendons. Knee surgery, sports traumatology, arthroscopy : official journal of the ESSKA 2013. 


\section{Chapter 2}

18. Bi Y, Ehirchiou D, Kilts TM, Inkson CA, Embree MC, Sonoyama W, Li L, Leet AI, Seo B-M, Zhang L et al: Identification of tendon stem/progenitor cells and the role of the extracellular matrix in their niche. Nature medicine 2007, 13(10):1219-1227.

19. Steinert AF, Kunz M, Prager P, Barthel T, Jakob F, Noth U, Murray MM, Evans CH, Porter RM: Mesenchymal stem cell characteristics of human anterior cruciate ligament outgrowth cells. Tissue engineering Part A 2011, 17(910):1375-1388.

20. Cheng MT, Yang HW, Chen TH, Lee OK: Isolation and characterization of multipotent stem cells from human cruciate ligaments. Cell proliferation 2009, 42(4):448-460.

21. Bianco P, Robey PG: Stem cells in tissue engineering. Nature 2001, 414(6859):118-121.

22. Wu Y, Chen L, Scott PG, Tredget EE: Mesenchymal stem cells enhance wound healing through differentiation and angiogenesis. Stem Cells 2007, 25(10):2648-2659.

23. Barrett AM, Craft JA, Replogle WH, Hydrick JM, Barrett GR: Anterior cruciate ligament graft failure: a comparison of graft type based on age and Tegner activity level. The American journal of sports medicine 2011, 39(10):2194-2198.

24. Mentink A, Hulsman M, Groen N, Licht R, Dechering KJ, van der Stok J, Alves HA, Dhert WJ, van Someren EP, Reinders MJT et al: Predicting the therapeutic efficacy of MSC in bone tissue engineering using the molecular marker CADM1. Biomaterials 2013, 34(19):4592-4601.

25. Gothard D, Dawson JI, Oreffo RO: Assessing the potential of colony morphology for dissecting the CFU-F population from human bone marrow stromal cells. Cell and tissue research 2013.

26. Fu S-C, Cheuk Y-C, Chan K-M, Hung L-K, Wong MW-N: Is cultured tendon fibroblast a good model to study tendon healing? Journal of Orthopaedic Research 2008, 26(3):374-383.

27. Zhang J, Pan T, Im HJ, Fu FH, Wang JH: Differential properties of human ACL and MCL stem cells may be responsible for their differential healing capacity. BMC medicine 2011, 9:68.

28. Tan Q, Lui PP, Rui YF, Wong YM: Comparison of potentials of stem cells isolated from tendon and bone marrow for musculoskeletal tissue engineering. Tissue engineering Part A 2012, 18(7-8):840-851.

29. Karuppiah SV, Banaszkiewicz PA, Ledingham WM: The mortality, morbidity and cost benefits of elective total knee arthroplasty in the nonagenarian population. International orthopaedics 2008, 32(3):339-343.

30. de Mos M, Koevoet WJ, Jahr H, Verstegen MM, Heijboer MP, Kops N, van Leeuwen JP, Weinans H, Verhaar JA, van Osch GJ: Intrinsic differentiation potential of adolescent human tendon tissue: an in-vitro cell differentiation study. BMC musculoskeletal disorders 2007, 8:16.

31. Rando TA: Stem cells, ageing and the quest for immortality. Nature 2006, 441(7097):1080-1086.

32. Davies DV: Anatomy and physiology of diarthrodial joints. Annals of the rheumatic diseases 1945, 5:29-35.

33. Cameron MB, A. Passler, H. Vogt, M. Thonar, E. Fu, Freddie. Evans, C.H.: The Natural History of the Anterior Cruciate Ligament-Deficient Knee: Changes in Synovial Fluid Cytokine and Keratan Sulfate Concentrations. The American journal of sports medicine 1997, 25:751-754.

34. Bigoni M, Sacerdote P, Turati M, Franchi S, Gandolla M, Gaddi D, Moretti S, Munegato D, Augusti CA, Bresciani E et al: Acute and late changes in intraarticular cytokine levels following anterior cruciate ligament injury. Journal of Orthopaedic Research 2013, 31(2):315-321.

35. Lui P, Zhang P, Chan K, Qin L: Biology and augmentation of tendon-bone insertion repair. Journal of orthopaedic surgery and research 2010, 5:59.

36. Yamazaki S, Yasuda K, Tomita F, Tohyama H, Minami A: The effect of transforming growth factor-beta1 on intraosseous healing of flexor tendon autograft replacement of anterior cruciate ligament in dogs. Arthroscopy : the journal of arthroscopic \& related surgery : official publication of the Arthroscopy Association of North America and the International Arthroscopy Association 2005, 21(9):1034-1041.

37. Hashimoto Y, Yoshida G, Toyoda H, Takaoka K: Generation of tendon-to-bone interface "enthesis" with use of recombinant BMP-2 in a rabbit model. Journal of orthopaedic research : official publication of the Orthopaedic Research Society 2007, 25(11):1415-1424. 
38. Demirag B, Sarisozen B, Ozer O, Kaplan T, Ozturk C: Enhancement of tendon-bone healing of anterior cruciate ligament grafts by blockage of matrix metalloproteinases. J Bone Joint Surg Am 2005, 87(11):2401-2410.

39. Ge Z, Goh JC, Lee EH: The effects of bone marrow-derived mesenchymal stem cells and fascia wrap application to anterior cruciate ligament tissue engineering. Cell transplantation 2005, 14(10):763-773.

40. Leung KS, Siu WS, Li SF, Qin L, Cheung WH, Tam KF, Lui PP: An in vitro optimized injectable calcium phosphate cement for augmenting screw fixation in osteopenic goats. Journal of biomedical materials research Part B, Applied biomaterials 2006, 78(1):153-160.

41. Sharma P, Maffulli N: Tendon Injury and Tendinopathy: Healing and Repair. The Journal of Bone \& Joint Surgery 2005, 87(1):187-202.

42. Murchison ND, Price BA, Conner DA, Keene DR, Olson EN, Tabin CJ, Schweitzer R: Regulation of tendon differentiation by scleraxis distinguishes force-transmitting tendons from muscle-anchoring tendons. Development 2007, 134(14):2697-2708.

43. Rossert J, Terraz C, Dupont S: Regulation of type I collagen genes expression. Nephrology Dialysis Transplantation 2000, 15(suppl 6):66-68.

44. Sacchetti B, Funari A, Michienzi S, Di Cesare S, Piersanti S, Saggio I, Tagliafico E, Ferrari S, Robey PG, Riminucci M et al: Self-renewing osteoprogenitors in bone marrow sinusoids can organize a hematopoietic microenvironment. Cell 2007, 131(2):324-336.

45. Niehage C, Steenblock C, Pursche T, Bornhauser M, Corbeil D, Hoflack B: The cell surface proteome of human mesenchymal stromal cells. PloS one 2011, 6(5):e20399. 



\section{Chapter 3}

\section{Means of enhancing bone fracture}

healing: optimal cell source, isolation methods, and acoustic stimulation

Ghebeş C.A., Braham M.V.J., Zeegers A.V.C.M., Renard A.J.S., Fernandes H.A.M. and Saris D.B.F. 


\section{AbstRact}

The human body has an extensive capacity to regenerate bone tissue following trauma. Large defects, however, such as long bone fractures of the lower limbs cannot be restored without intervention and often lead to nonunion. Therefore, the aim of the present study is to assess the pool and biological functions of human mesenchymal stromal cells (hMSCs) isolated from different bone marrow locations of the lower limbs, and to identify novel strategies to prime the cells prior to their use in bone fracture healing. Bone marrow from the ilium, proximal femur, distal femur, and proximal tibia was aspirated and the hMSCs isolated. Bone marrow type, volume, number of mononuclear cells / hMSCs and their self-renewal, multilineage potential, extracellular matrix (ECM) production, and surface marker profiling were analysed. Additionally, the cells were primed to accelerate bone fracture healing either by using acoustic stimulation or varying the initial hMSCs isolation conditions. We found that the more proximal the bone marrow aspiration location, the larger the bone marrow volume was, the higher the content of mononuclear cells / hMSCs, and the higher the self-renewal and osteogenic differentiation potential of the isolated hMSCs were. Acoustic stimulation of bone marrow, as well as the isolation of hMSCs in the absence of fetal bovine serum, increased respectively the osteogenic and ECM production potential of the cells. Our results show that bone marrow properties change with the aspiration location, potentially explaining the differences in bone fracture healing between the tibia and the femur. Furthermore, we show two new priming methods capable of enhancing bone fracture healing. 


\section{INTRODUCTION}

Musculoskeletal disorders that affect the body's muscles, bones, joints, tendons, ligaments, and nerves and are the leading cause of chronic disabilities in adults [1]. Significant research efforts have been undertaken during the past few decades to ease this disability and improve patient mobility and quality of life. Bone fracture repairs have been intensively investigated at both the clinical and fundamental level and yet still $5-10 \%$ of fractures resulted in either delayed repair (delayed union) or no repair (nonunion) [2]. At present, there are two primary treatment strategies: (1) surgical intervention that implies the use of bone autograft/allografts, demineralised bone matrix, or synthetic materials; and (2) noninvasive treatments, such as the application of acoustic energy that has been shown to be beneficial in fracture healing $[3,4]$. Nevertheless, these strategies rely on the patient's own cells - either stem and/or committed - to induce bone regeneration, posing a challenge in situations where those cells are missing and/or less active. In these cases, cell-based alternatives, such as the use of human mesenchymal stromal cells (hMSCs) were proposed [5].

In this study, we explored the yield, proliferation, multilineage differentiation, and extracellular matrix (ECM) production potential of hMSCs isolated from bone marrow (BM) aspirated from the lower limbs, such as the ilium, proximal femur, distal femur, and proximal tibia. Besides that, we examined the inter- and intra-donor variation between the BM-derived hMSCs from the different locations. Currently, the nonunion rate in bone fracture healing (BFH) differs regarding location, with fractures at tibia diaphysis healing slower (nonunion rate of 18.5\% [6]) than fractures in the femoral shaft (nonunion rate of $1.7 \%$ [7]). Accordingly, we hypothesise that BM located at the fracture site might play an important role in fracture healing rate, due to differences in cell number, self-renewal-, proliferative-, ECM production- and multilineagedifferentiation potential.

Additionally, as cell-based therapies are already used in musculoskeletal pathologies, such as bone fracture, pseudarthrosis, and osteochondral defects [8, 9], we explored the potential of priming BM-derived hMSCs towards a better osteogenic differentiation potential in order to accelerate tissue regeneration upon reimplantation. We explored two distinct priming strategies: (1) the use of acoustic energy applied on BM; and (2) varying the initial culture conditions of the isolated hMSCs.

Ultrasound has been shown to have beneficial effects on BFH, showing an increase in bone formation [10, 11], though not consistently [12-14]. Moreover, the $42 \%$ acceleration rate in fracture healing in patients exposed to a 20 minute daily ultrasound treatment is still not excellent [11]. Therefore, we believe that the use of acoustically stimulated BM injected at the fracture site might have a greater impact on BFH than standard ultrasound treatment. Mechanical stimulation has been shown to pre-commit hMSCs towards the osteogenic lineage [15], so we hypothesise that acoustic energy applied directly on BM might induce the commitment of hMSCs towards osteogenesis. It is clinically feasible and simple to apply a short period of acoustic sound cell 
manipulation on a BM aspirate during fracture surgery, after which the BM can be administrated to the fracture site either in initial surgery during high risk cases or as an adjunct to revision surgery in case of pseudarthrosis.

Secondly, cell-based therapies often involve the in vitro expansion of cells, where the isolation procedure plays an important role in the selection of desired cell population [16-18]. The isolation of hMSCs from BM is mainly achieved by plastic adherence and it is recognised that both the number of mononuclear cells (MNCs) plated, and the culture media, have a strong influence on the selection of certain hMSCs populations [19]. Accordingly, we hypothesise that low MNC seeding density might select hMSCs prone to higher self-renewal potential, while the use of serum free (SF) media might select an hMSCs subpopulation with enhanced potency. The phenotype of the isolated hMSCs under the aforementioned procedures were compared to a previously described isolation procedure [20].

With this study we aimed to find the optimal ratio between aspirated BM volume and MNC concentration to explain the difference in cell phenotype between the different $\mathrm{BM}$ locations of lower limb extremities, and to propose new methods that could accelerate BFH. A schematic overview of the experimental design is presented in Figure 1.

\section{MeTHODS}

\section{Aspiration of bone marrow}

Bone marrow aspirates were obtained from patients undergoing total hip arthroplasty (THA) or total knee arthroplasty (TKA). An 8G Jamshidi BM needle fitted with a 50$\mathrm{mL}$ Luer lock syringe containing $1 \mathrm{~mL}$ of 1,000 $\mathrm{U}$ heparin per $10 \mathrm{~mL}$ BM was used to aspirate the BM. Subsequently, the BM was transferred to blood collection tubes (BD367526) for transport from the operating theatre to the laboratory. The BM was kept at ambient room temperature until being processed the same day.

Bone marrow was aspirated from four different locations: the supra acetabular sulcus (ilium) in 12 donors; the medullary cavity or lateral diaphysis of the femur (proximal femur) in seven donors; and the epiphysis or medullary cavity from the distal femur or proximal tibia in seven more donors.

The collection and anonymous use of the BM aspirate was approved and performed in compliance with the relevant laws and institutional guidelines of the Medisch Spectrum Twente, Twente Ethische Toetsings Commissie (Ref. no.: K13-46). Patients provided written informed consent after being provided with a verbal explanation and an opportunity for questioning. 


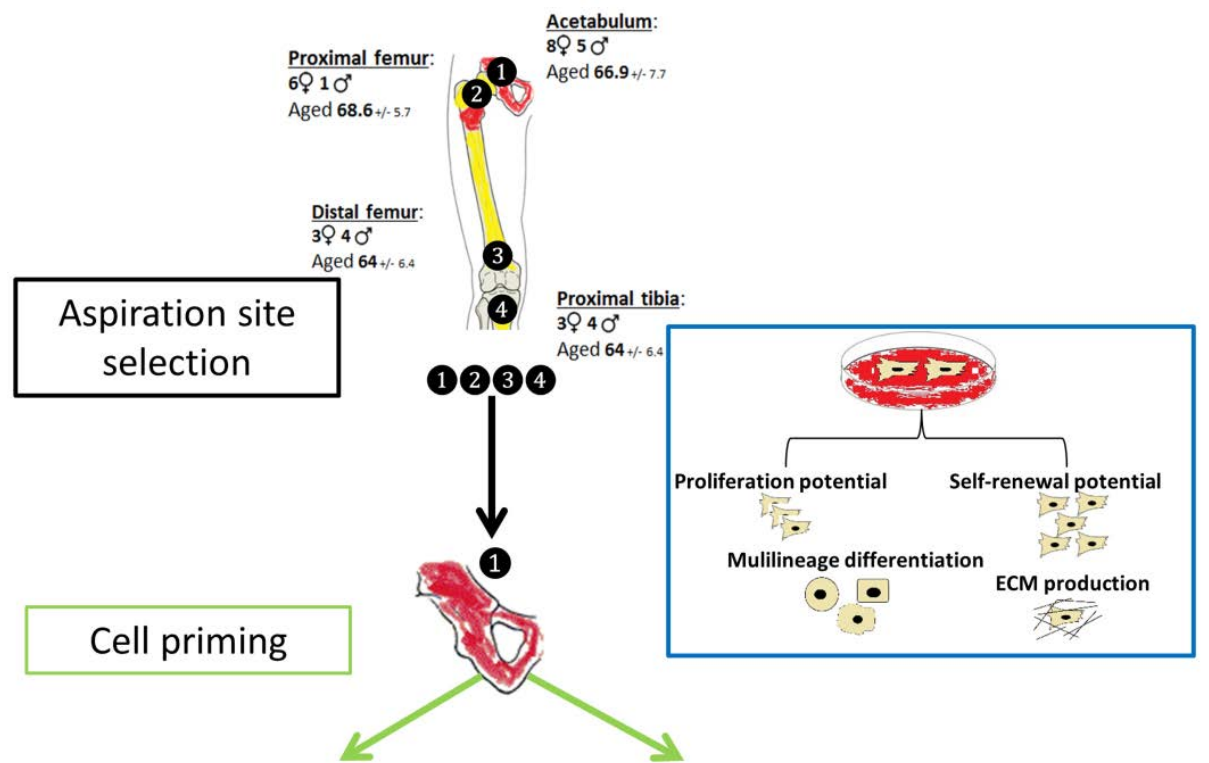

Cell priming by applying acoustic stimulation Cell priming by varying the initial culture conditions
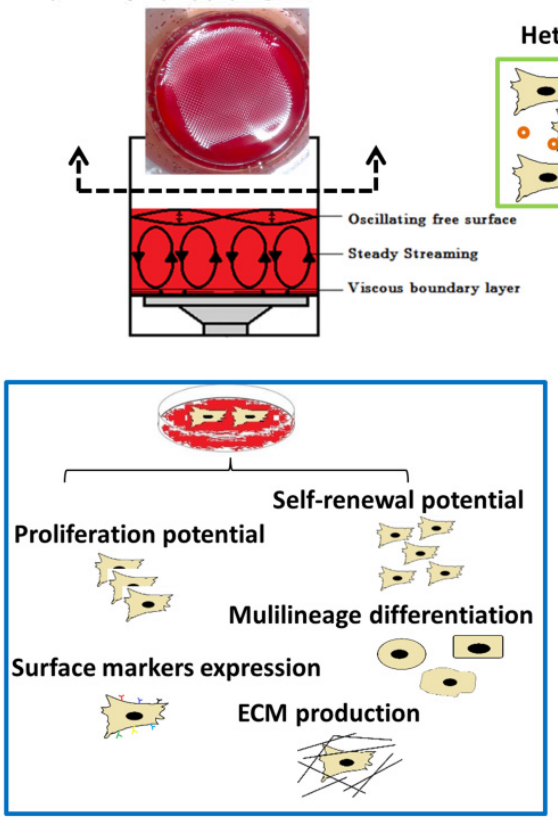

Heterogeneous

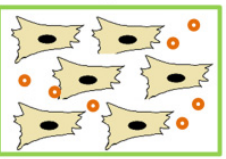

Proliferation potential Multilineage differentiation

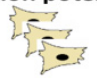

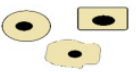

Surface markers expression

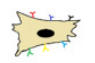

ECM production

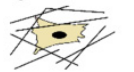

Figure 1. Schematic representation of the experimental design. Aspiration of BM from different locations of lower limb extremities and selection of the optimal cell source, based on hMSC number and phenotype. In vitro priming of hMSC by use of acoustic stimulation or varying the initial culture conditions with the final aim to enhance in vivo BFH. 


\section{Isolation and culture of hMSCs}

Bone marrow aspirate was passed through a $70 \mu \mathrm{m}$ pore-size cell strainer, to remove the presence of tissue pieces, after which MNC concentration from the ilium and proximal femur was analysed using the Beckman coulter ACT diff 2. The number of MNCs for samples collected from the distal femur and proximal tibia was not analysed due to technical limitations.

Based on the isolation method used, different concentrations of $\mathrm{MNCs} / \mathrm{cm}^{2}$ were plated. We defined three isolation/culture conditions: heterogeneous (classical MNC seeding density, previously described and standardised hMSCs isolation protocol within our laboratory [21]); multiclonal (low MNC seeding density, permissive for single cell clonal expansion); and SF (high MNC seeding density in the absence of fetal bovine serum proteins during the initial phase).

For the heterogeneous isolation condition, BM aspirate was plated at a density of $5 \times 10^{5}$ $\mathrm{MNCs} / \mathrm{cm}^{2}$ and cultured in growth media (GM) consisting of $\alpha$-minimal essential media ( $\alpha$ MEM, Life Technologies - Cat. No.: 22571-020); 10\% Fetal Bovine Serum (FBS, Gibco - Cat. No.: 10270106); $0.2 \mathrm{mM}$ L-ascorbic acid 2-phosphate magnesium salt (Sigma - Cat. No.: A8960); 2 mM L-glutamine (Gibco - Cat. No.: BE17-605E); 100 units/mL penicillin; and $100 \mathrm{mg} / \mathrm{mL}$ streptomycin (Gibco - Cat. No.: 15140-122).

For the multiclonal isolation condition, BM aspirate was plated at a clonal density of $5 \times 10^{4} \mathrm{MNCs} / \mathrm{cm}^{2}$ and cultured in GM.

For the SF condition, BM aspirate was plated at a cell density of $1.5 \times 10^{6} \mathrm{MNC} / \mathrm{cm}^{2}$ in $\alpha$-MEM containing no additives for the first three days.

On the fourth day, the non-adherent cell fraction was removed and the media were changed to GM for all three conditions. Hereafter, the media were refreshed twice a week. At semi-confluence, the cells were trypsinised and used for sub-culturing or stored in liquid nitrogen for future use.

In total, BM was aspirated from 19 donors and subsequently divided between the different experiments. BM from 14 donors was used to evaluate the most convenient aspiration site location. BM was plated under heterogeneous conditions, with the exception of the distal femur and proximal tibia where $2 \mathrm{ml} \mathrm{BM}$ was plated each time, as the initial amounts of MNCs were unknown. BM from 11 donors was used to evaluate the effects of acoustic energy. The BM was plated under heterogeneous conditions. And $\mathrm{BM}$ from six donors was used to evaluate the effects of varying the initial isolation conditions of the hMSCs.

Donor number, BM aspiration location, BM volume, and the concentration of MNCs/ml can be found in Table 1 . BM was cultured at $37^{\circ} \mathrm{C}$ and $5 \% \mathrm{CO}_{2}$. 


\begin{tabular}{|c|c|c|c|c|}
\hline $\begin{array}{l}\text { Donor } \\
\text { number }\end{array}$ & $\begin{array}{l}\text { BM } \\
\text { location }\end{array}$ & BM colour & $\begin{array}{l}\text { BM } \\
\text { aspirated } \\
\text { volume }(\mathrm{ml})\end{array}$ & $\begin{array}{l}M N C / m l \\
\left({ }^{*} E+06\right)\end{array}$ \\
\hline Donor 1 & Ilium & Red & 20 & 31.6 \\
\hline Donor 2 & Ilium & Red & 35 & 12.3 \\
\hline Donor 3 & Ilium & Red & 15 & 17.9 \\
\hline Donor 4 & Ilium & Red & 25 & 20.2 \\
\hline Donor 5 & Ilium & Red & 30 & 13.5 \\
\hline \multirow[t]{2}{*}{ Donor 6} & Ilium & Red & 28 & 6.8 \\
\hline & Proximal Femur & Red & 11.5 & 16.3 \\
\hline \multirow[t]{2}{*}{ Donor 7} & Ilium & Red & 20 & 16.1 \\
\hline & Proximal Femur & Red & 1 & 15.1 \\
\hline \multirow[t]{2}{*}{ Donor 8} & Ilium & Red & 13 & 34.7 \\
\hline & Proximal Femur & Red & 6 & 16.2 \\
\hline \multirow[t]{2}{*}{ Donor 9} & Ilium & Red & 20 & 7.3 \\
\hline & Proximal Femur & Red & 6.5 & 7.9 \\
\hline \multirow[t]{2}{*}{ Donor 10} & Ilium & Red & 22.5 & 14.5 \\
\hline & Proximal Femur & Red & 9 & 22.4 \\
\hline \multirow[t]{2}{*}{ Donor 11} & Ilium & Red & 22.5 & 7.4 \\
\hline & Proximal Femur & Red & 5 & 6.4 \\
\hline \multirow[t]{2}{*}{ Donor 12} & Ilium & Red & 7.5 & 26.6 \\
\hline & Proximal Femur & Red & 5 & 37 \\
\hline \multirow[t]{2}{*}{ Donor 13} & Distal Femur & Yellow & 3.5 & - \\
\hline & Proximal Tibia & Yellow & 2.5 & - \\
\hline \multirow[t]{2}{*}{ Donor 14} & Distal Femur & Yellow & 5 & - \\
\hline & Proximal Tibia & Yellow & 7.5 & - \\
\hline \multirow[t]{2}{*}{ Donor 15} & Distal Femur & Yellow & 9 & - \\
\hline & Proximal Tibia & Yellow & 3 & - \\
\hline \multirow[t]{2}{*}{ Donor 16} & Distal Femur & Yellow & 2 & - \\
\hline & Proximal Tibia & Yellow & 1.5 & - \\
\hline \multirow[t]{2}{*}{ Donor 17} & Distal Femur & Yellow & 6 & - \\
\hline & Proximal Tibia & Yellow & 7 & - \\
\hline \multirow[t]{2}{*}{ Donor 18} & Distal Femur & Yellow & 8 & - \\
\hline & Proximal Tibia & Yellow & 4.5 & - \\
\hline \multirow[t]{2}{*}{ Donor 19} & Distal Femur & Yellow & 2 & - \\
\hline & Proximal Tibia & Yellow & 2 & - \\
\hline
\end{tabular}

Table 1. BM information. From left to right: donor number, BM aspiration location, type, aspiration location and concentration of MNCs $/ \mathrm{ml}$.

\section{hMSCs population doubling}

To assess hMSC proliferation, cells from passage 1 (P1) were seeded in GM at 5,000 cells $/ \mathrm{cm}^{2}$ in T175 tissue culture flasks. At semi-confluence, the cells were trypsinised and counted. Population doubling (PD) was calculated per the formula $\mathrm{PD}=$ $\log _{2}\left(\mathrm{~N}_{\mathrm{E}} / \mathrm{N}_{\mathrm{i}}\right)$, where $\mathrm{N}_{\mathrm{E}}$ and $\mathrm{N}_{\mathrm{I}}$ are the number of hMSCs obtained at passage 2 (P2) and $\mathrm{P} 1$, respectively. 


\section{Colony forming unit and colony forming unit-osteoblast potential (mineralisation)}

The colony forming unit (CFU) assay was used as an indicator of self-renewal potential of the hMSCs, and the CFU-osteoblast (CFU-Ob) assay was used as an indicator of osteoprogenitor presence in the formed CFUs. Two million MNCs were seeded in duplicate in T25 culture flasks and grown in GM for the first seven days, followed by transition to mineralisation media for a further seven days. The mineralisation media consisted of GM containing $0.01 \mathrm{M} \beta$-glycerophosphate (BGP, Sigma - Cat. No.: G9422) and $10^{-8}$ M Dexamethasone (Dex, Sigma - Cat. No.: D8893). At day 14, the cultures were fixed with $10 \%$ formalin for $15 \mathrm{~min}$ at ambient temperature, after which alkaline phosphatase (ALP) positive colonies were stained using the Leukocyte Alkaline Phosphatase Kit -ALP (Sigma - Cat. No.: 85L2) following the manufacturer's instructions. Subsequently, the total number of colonies formed were stained using 0.5\% Coomassie Briljant Blue staining (Fluka - Cat. No.: 27815) solution added to the monolayer for 10 minutes. Images of the stained colonies were acquired using an Epson Perfection V750 PRO scanner. The total number of CFUs and ALP positive colonies was quantified using ImageJ 1.45s software and the percentage of ALP positive CFUs calculated.

\section{Extracellular matrix production}

hMSCs at P2 or P3 were seeded in quadruplicate of 100,000 cells/well in a 384-well plate in GM (without serum) consisting of $50 \mu \mathrm{g} / \mathrm{mL}$ insulin transferrin seleniumpremix (Sigma - Cat. No.: I3146) and $40 \mu \mathrm{g} / \mathrm{mL}$ proline (Sigma - Cat. No.: P5607) and incubated for $24 \mathrm{~h}$ to allow cell adhesion. The following day, the medium was refreshed and $10 \mathrm{ng} / \mathrm{mL}$ transforming growth factor beta 3 (R\&D Systems - Cat. No.: 243-B3) and $10^{-7} \mathrm{M}$ Dex were added to the wells. After seven days, the formed nodules were fixed in $10 \%$ formalin for $15 \mathrm{~min}$ at ambient temperature and images were captured using a Nikon bright field microscope. The nodule area and the number of nodules formed were quantified using ImageJ 1.45s software. The early cell condensation phenotype and the increase in nodule size were associated with ECM production.

\section{Alizarin red staining (mineralisation)}

hMSCs at P2 or P3 were seeded in triplicate of 50,000 cells/well in T25 and grown in control media consisting of GM containing $0.01 \mathrm{M}$ BGP and in a mineralisation medium consisting of GM containing BGP and $10^{-8} \mathrm{M}$ Dex. The media were refreshed twice a week. After 28 days, the cells were fixed in $10 \%$ formalin for 15 minutes at ambient temperature and stained with $2 \%$ Alizarin red solution (Sigma - Cat. No.: A5533) for five minutes. Images were captured using a Nikon bright field microscope. 


\section{Oil Red O staining (Adipogenesis)}

hMSCs at P2 or P3 were seeded in triplicate of 25,000 cells/well in 24-well plates and grown in a control medium consisting of GM or adipogenic medium consisting of GM containing $0.2 \mathrm{mM}$ indomethacin (Cat. No.: I7378); $0.5 \mathrm{mM}$ isobutylmethylxanthine (Cat. No.: I5879); 10-6 M Dex; and $10 \mu \mathrm{g} / \mathrm{mL}$ human insulin (Cat. No.: I9278), all from Sigma. The media were refreshed twice a week. After three weeks, the cells were fixed with $10 \%$ formalin for 15 minutes at ambient temperature, after which the cell monolayer was incubated for five minutes in $60 \%$ isopropanol, and subsequently stained with Oil Red O solution (3mg/mL in 60\% isopropanol, Sigma - Cat. No.: O0625). After five minutes, the samples were rinsed with demineralised water and images were captured using a Nikon bright field microscope. After the imaging, Oil Red O staining was extracted from the cells in 4\% Nonidet P40 (Fluka, Cat. No.: 74385) in isopropanol and absorbance was measured at $540 \mathrm{~nm}$ (Lambda 40; Perkin Elmer). One hundred percent Oil Red $\mathrm{O}$ was included in the calibration curve measurements, from which the percentage of Oil Red O staining was calculated.

\section{Flow cytometry}

hMSCs at P3 or P4 were expanded in T175 until they reached confluence. The cells were trypsinised and incubated for 30 minutes in blocking buffer consisting of $17 \%$ bovine serum albumin (Sigma - Cat. No.: F7524) in phosphate buffered saline (PBS). This was followed by incubation with FITC- or PE-conjugated mouse anti-human antibodies for 30 minutes at $4^{\circ} \mathrm{C}$ in the dark. The samples were then washed three times with a washing buffer consisting of $3 \%$ bovine serum albumin in PBS. The expression levels were analysed using a FACSAria flow cytometer (BD Bioscience). For phenotypic characterisation, the following antibodies were used: CD90, CD73, CD146, CD105, CD271, CD34, CD14, CD79a, HLA-DR, CD45, and IgG1 and Ig G2a as isotype controls (all from BD pharming).

\section{Acoustic stimulation of bone marrow}

Acoustic stimulation of BM was achieved using the bone marrow aspirate concentration device, previously described by Ridgway et al. [22]. BM was placed into the processing chamber of the device and acoustic vibration was applied using a voice-coil that produced a geometric standing waveform pattern on the BM fluid surface. Different frequencies were tested by manual adjustment using an Oscilloscope (Agilent Technologies, InfiniVision, MSO-X-3014A Mixed Signal Oscilloscope) and two frequencies, $300 \mathrm{~Hz}\left(48 \mathrm{~mW} / \mathrm{cm}^{2}\right)$ and $500 \mathrm{~Hz}\left(73 \mathrm{~mW} / \mathrm{cm}^{2}\right)$, were selected for further experimental research. The BM was processed one time for five and 10 minutes for both selected frequencies. The baseline was defined as unstimulated BM.

Part of the BM was plated to assess the self-renewal and proliferation potential as previously described, while the rest of the BM was plated under the heterogeneous hMSCs isolation condition in order to assess the multilineage differentiation potential, 
ECM production, and surface markers expression of the hMSCs at a later passage, as previously mentioned.

\section{Bone marrow viscosity}

Bone marrow viscosity from six donors (three donors for ilium and proximal femur and three donors for distal femur and proximal tibia) was measured using the Rheometer Physica MCR-301. A total of 30 different points, with an increasing shear rate from 0 to 250 1/s and periodic pause of 10 seconds between each point, were measured. The volume of BM used for the measurements was $350 \mu$ per measuring cycle. All samples were measured in duplicates at ambient room temperature.

\section{Statistical analysis}

Statistical analysis was performed using Graphpad Prism 6 software. An unpaired Student's $t$-test and Mann-Whitney post-test were performed to compare the data when two groups were analysed. One-way or two-way analysis of variance (ANOVA) and a Tukey or Bonferroni post-test were used to compare the data when more than two groups were analysed. The uniform distribution of data, to test inter-donor variation, was assessed using a Chi-squared test. A $\mathrm{P} \leq 0.05$ indicates a statistical significant difference. The results are shown as mean \pm standard deviation.

\section{RESULTS}

\section{Inter-donor variability in bone marrow aspirate}

The volume of BM aspirated from the different locations varied significantly, with larger BM volumes obtained from the ilium $(22 \pm 7.6 \mathrm{ml})$ than the proximal femur $(6 \pm$ $3.3 \mathrm{ml})$, distal femur $(5 \pm 2.9 \mathrm{ml})$, or proximal tibia $(4 \pm 2.6 \mathrm{ml})$. BM volumes from the ilium yielded a higher concentration of MNCs for volumes close to $10 \mathrm{ml}\left(2.6 \times 10^{7}\right.$ $\mathrm{MNC} / \mathrm{ml}$ ), while volumes close to and larger than $20 \mathrm{ml}$ yielded a lower concentration of MNCs $\left(1.4 \times 10^{7} \mathrm{MNC} / \mathrm{ml}\right)$. This, however, was not statistically significant $(\mathrm{p}=$ 0.15). Similarly, BM aspirated from the proximal femur showed higher MNC yield for volumes lower than $5 \mathrm{~mL}, 2 \times 10^{7} \mathrm{MNC} / \mathrm{mL}$ versus $1.6 \times 10^{7} \mathrm{MNC} / \mathrm{mL}$. Again, however, this was not statistically significant $(\mathrm{p}=0.7)$ (Figure $2 \mathrm{~A}$ and Table 1$)$.

The concentration of hMSCs obtained at the end of the expansion phase (14 days after MNC seeding) was, on average, 566,494 hMSC/ml for the ilium; 245,549 hMSC/ml for the proximal femur; 76,250 hMSC/ml for the distal femur; and 122,321 hMSC/ml for the proximal tibia samples (Figure 2B). No statistically significant differences were found between the groups; however, lower p values were obtained from hMSCs isolated from proximal versus distal locations (Supplementary Table 1).

Macroscopically, the BM aspirated from the ilium and proximal femur was red, while $\mathrm{BM}$ aspirated from distal femur and proximal tibia was yellow, consistent with a higher 
A

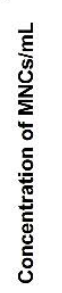

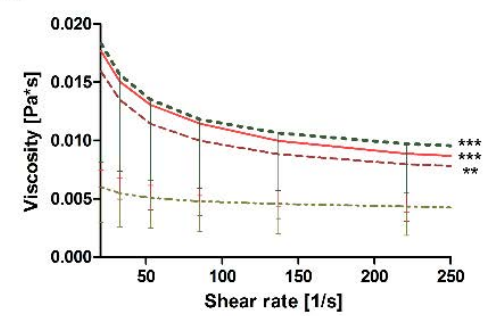

B

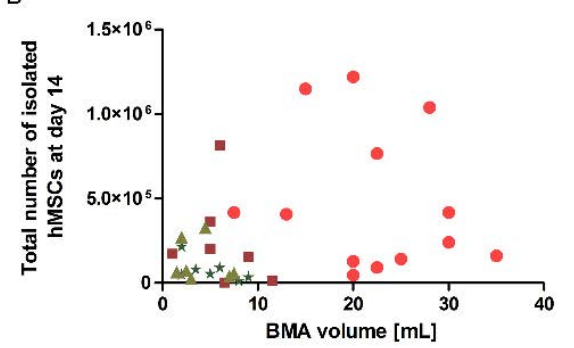

- - llium

- -.- Proximal Femur

* ... Distal Femur

A ..- Proximal Tibia

Figure 2. Characterisation of BM aspirated (BMA) from different locations. (A) Correlation between aspirated BM volume and MNC concentration, for the ilium (circle) and proximal femur (square). (B) Correlation between the plated BM volumes and the number of isolated hMSCs, heterogeneous isolation condition only. (C) BM viscosity curves from different aspiration locations, represented as correlation between the shear rate and the viscosity. The values represented the mean \pm standard deviation of three BM donors ( $n$ $=3$ ). Statistically significant differences were found with ${ }^{* * *} p<0.001$ and ${ }^{* *} p<0.01$.

presence of lipid droplets in the latter (Supplementary Figure 1). Compared with the other aspiration locations, we observed a significant decrease in BM viscosity for BM aspirated from the proximal tibia (Figure 2C). The morphological appearance of expanded hMSCs did not show any visible differences between the different BM aspiration locations (data not shown).

\section{Effect of aspiration location on biological characteristics of hMSCs}

Proliferation, self-renewal ECM production, and multilineage potential (osteo and adipogenic) were assessed for hMSCs isolated from the different locations (Figure 3). Proliferation capacity and ECM production of hMSC showed a uniform distribution across all donors, for each BM aspiration location independently (Figure 3A, E). An average across all donors showed a statistically significant increase in proliferation of hMSCs isolated from the distal femur $(0.64 \pm 0.07)$ and proximal tibia $(0.71 \pm 0.08)$ when compared with the ilium $(0.47 \pm 0.09)$ and proximal femur $(0.48 \pm 0.13)$ (Figure $3 B$ ). No statistical significant differences were seen in ECM production, however (Figure 3F).

In contrast, the CFU capacity of hMSCs showed a non-uniform distribution across all donors, independent of the BM location (Figure 3C). The average across all donors showed a trend towards a higher CFU capacity of hMSCs isolated from the proximal 
femur $54 \pm 42$ CFU compared with the ilium $31 \pm 22$ CFU, distal femur $14 \pm 24$ CFU, and proximal tibia $19 \pm 5 \mathrm{CFU}$ (Figure 3D). The obtained p values can be visualised in Supplementary Table 2.

Similarly, the mineralisation capacity showed a similar trend with a higher CFU-Ob potential in hMSCs isolated from the ilium $12 \pm 11$ CFU-Ob (36\% \pm 18 CFU-Ob/CFU) and proximal femur $11 \pm 10 \mathrm{CFU}-\mathrm{Ob}(26 \% \pm 16 \mathrm{CFU}-\mathrm{Ob} / \mathrm{CFU})$ compared with the distal femur $1 \pm 1 \mathrm{CFU}-\mathrm{Ob}(13 \% \pm 20 \mathrm{CFU}-\mathrm{Ob} / \mathrm{CFU})$ and proximal tibia $5 \pm 11 \mathrm{CFU}-$ $\mathrm{Ob}(17 \% \pm 22 \mathrm{CFU}-\mathrm{Ob} / \mathrm{CFU})$ (Figure $3 \mathrm{H})$. The obtained p values can be visualised in Supplementary Table 2. The high standard deviation is attributed to the non-uniform distribution across the donors (Figure 3G).

The adipogenic potential of hMSCs showed a uniform distribution across all donors for BM aspirated from the ilium and proximal femur, but not from the distal femur and proximal tibia (Figure 3I). The average across all donors showed a significant increase in stained fat droplets in the proximal tibia $21 \% \pm 6.85$ when compared with the ilium $9 \% \pm 2.5$. No statistically significant differences were observed between the other groups (Figure 3J).

\section{Effect of acoustic stimulation on hMSCs}

Self-renewal, proliferation, ECM production, and multilineage potential (osteo and adipogenic) were assessed from the acoustic stimulated hMSCs.

The different BM volumes harvested from the different donors - $11.5 \mathrm{ml}$ (donor 3), 10 $\mathrm{ml}$ (donor 5), $8 \mathrm{ml}$ (donor 4), $6 \mathrm{ml}$ (donor 1), and $5 \mathrm{ml}$ (donor 2) (Supplementary Figure 2A) - were stimulated at a frequency of $300 \mathrm{~Hz}$ for five and 10 minutes (Supplementary Figure 2B-F). Upon acoustic stimulation, a significant increase in CFU, mineralisation, and adipogenesis was observed for hMSC isolated from small BM volumes (5 and 6 $\mathrm{mL}$ ) rather than larger volumes $(8,10$, or $11.5 \mathrm{ml})$. No statistically significant differences were observed in proliferation or ECM production between the conditions. Based on the abovementioned results, subsequent experiments were performed using small BM volumes $(4 \mathrm{ml})$. An illustration of the device, while $4 \mathrm{ml}$ of $\mathrm{BM}$ is acoustically stimulated at $300 \mathrm{~Hz}$, is presented in Figure 4.

Acoustic stimulation of $\mathrm{BM}$ at 300 and $500 \mathrm{~Hz}$ for five and 10 minutes showed no statistically significant difference in hMSC proliferation between the conditions (Figure 5A, B). In contrast, an increase (not significant) in CFU, ECM production, and mineralisation but not in adipogenic potential was observed upon acoustic stimulation (Figure 5C - J).

Surface marker expression on hMSCs isolated from acoustically stimulated BM $(300 \mathrm{~Hz}$ for five minutes) showed a decrease, though not statistically significant, in expression of positive surface markers such as CD105 (22 $\pm 3 \%$ versus $32 \pm 17 \%$ ); CD90 (21 $\pm 5 \%$ versus $23 \pm 7 \%$ ); CD146 (3 $\pm 1 \%$ versus $4 \pm 1 \%$ ); and CD73 (20 $\pm 8 \%$ versus $23 \pm 17$ $\%)$ when compared with the baseline (Supplementary Figure 3). 
Proliferation

Average
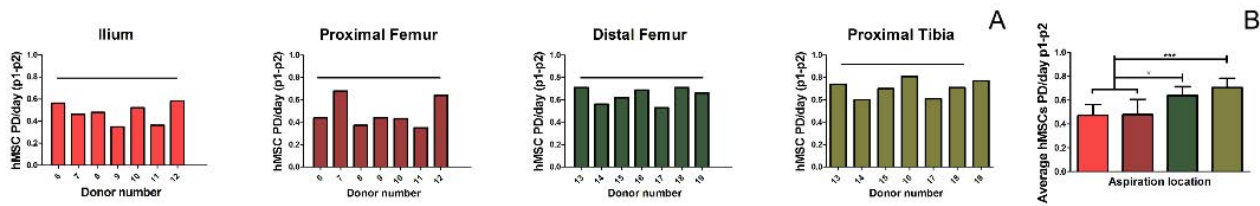

CFU

Average
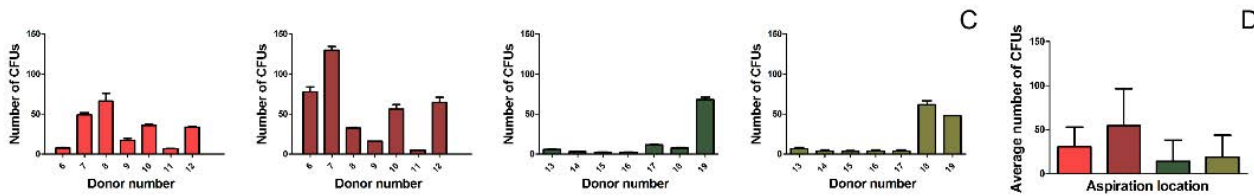

ECM production
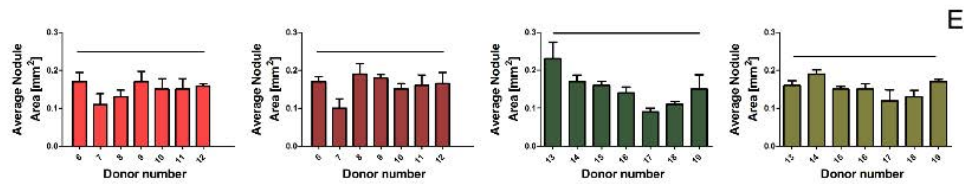

Average

E

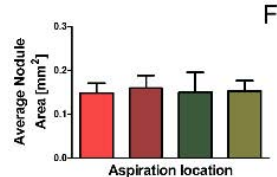

CFU-Ob (Osteogenesis)
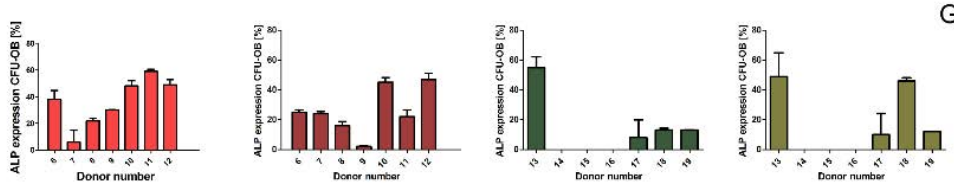

Average

G

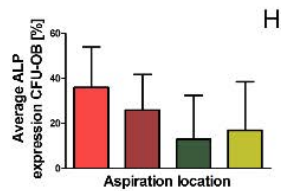

Oil red O (Adipogenesis)
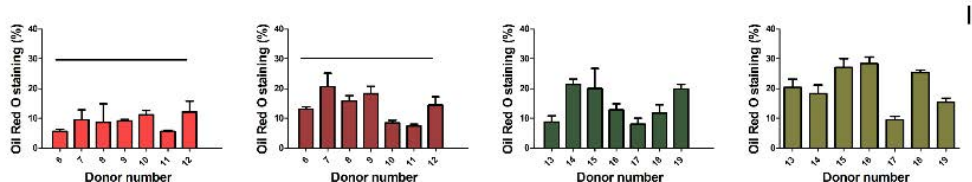

Average

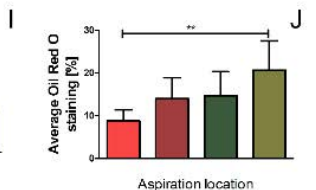

Figure 3. Biological characterisation of hMSCs isolated from different BM locations. (A) Proliferation of hMSCs calculated as PD/day from P1 to P2, donor and location dependent. (B) Proliferation average across the donors. (C) CFU potential of hMSCs, donor and location dependent. (D) CFU average across the donors. (E) ECM production, quantification of nodule size area in $\mathrm{mm}^{2}$ after cell condensation, donor and location dependent. (F) ECM production average. (G) Osteogenic potential calculated as percentage of ALP positive colonies within the CFUs, donor and location dependent. (H) Osteogenesis average. (I) Adipogenic potential, quantification of Oil Red O staining relative to $100 \%$ Oil Red $O$ staining solution, donor and location dependent. (J) Adipogenesis average. The uniform distribution of data, to test inter-donor variation, was assessed using Chi-squared test and presented as a line above all donors. Values are represented as the mean \pm standard deviation of at least three independent experiments $(n \geq 3)$. Statistically significant differences were found with $* * * p<0.001,{ }^{* *} p<0.01$ and ${ }^{*} p<0.05$. 


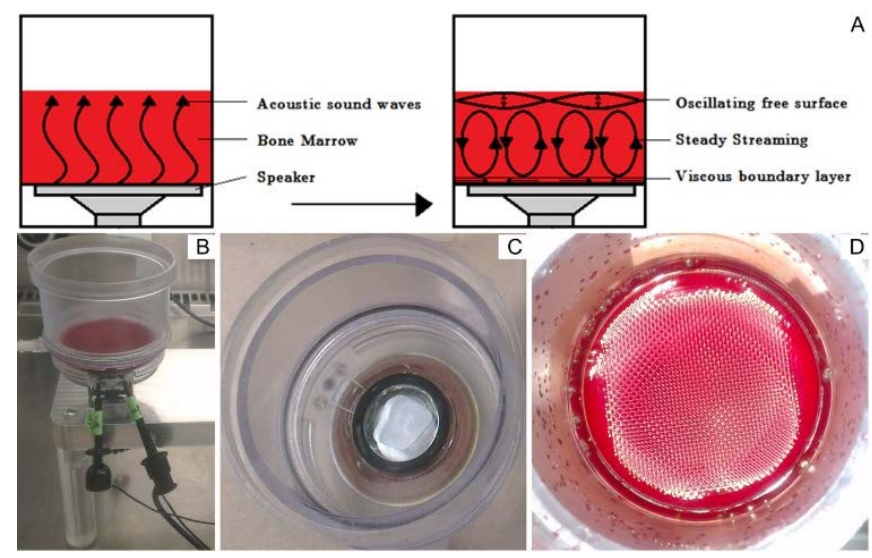

Figure 4. Acoustic stimulating device. (A) Sketch of the fluid flow within the processing chamber and the formation of a standing wave. (B) Processing chamber. (C) Speaker, in white, located on the bottom of the processing chamber. (D) Standing wave pattern formed in $\mathrm{BM}$ at $300 \mathrm{~Hz}$.

\section{Effect of varying the initial culture condition on hMSCs}

The isolation of hMSCs from the BM was assessed by varying the initial culture conditions and their proliferation, ECM production, multilineage differentiation potential, and cell surface marker expression. No difference in proliferation (Figure 6A, B, and Supplementary Table 3) and osteogenesis (Supplementary Figure 4) was observed between the different isolation conditions. In contrast, the isolation of hMSCs under SF conditions showed a trend in increased ECM production, with four out of six donors showing a statistically significant increase (Figure 6C). When averaged across all donors, $p$ values of 0.11 and 0.18 were obtained when compared with heterogeneous and multiclonal conditions (Figure 6D and Supplementary Table 3). Additionally, SF conditions showed a trend in decreased adipogenesis, with five out of six donors showing a statistically significant decrease (Figure 6E). When averaged across all donors, $\mathrm{p}$ values of 0.48 and 0.13 were obtained when compared with heterogeneous and multiclonal conditions (Figure 6F and Supplementary Table 3); while isolation of hMSCs under multiclonal condition showed a trend in increased adipogenesis (Figure $6 \mathrm{E}$ ). A statistically significant increase in adipogenesis was observed in five out of six donors in multiclonal when compared with SF isolated hMSCs (Figure 6E and F, Supplementary Table 3).

The expression of CD271, CD34, CD14, CD79a, CD45, and HLA-DR was absent in all conditions, regardless of the isolation procedure; while no significant differences were observed in the expression of CD90 (46 $\pm 31 \%$ heterogeneous versus $36 \pm 26 \%$ multiclonal and $43 \pm 36 \%$ serum free condition); CD105 (11 $\pm 6 \%$ heterogeneous versus $23 \pm 14 \%$ multiclonal and $34 \pm 31 \%$ serum free condition); CD73 (27 $\pm 7 \%$ heterogeneous versus $33 \pm 18 \%$ multiclonal and $43 \pm 33 \%$ serum free condition); and CD146 ( $5 \pm 4 \%$ heterogeneous versus $5 \pm 4 \%$ multiclonal and $11 \pm 16 \%$ serum free 
A

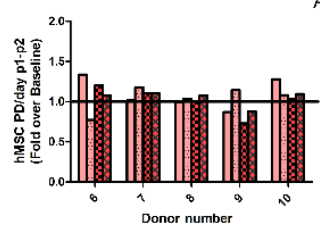

Average

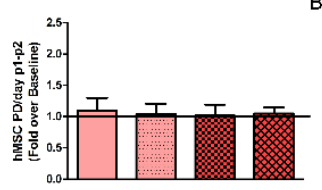

CFU-Ob (Osteogenesis)

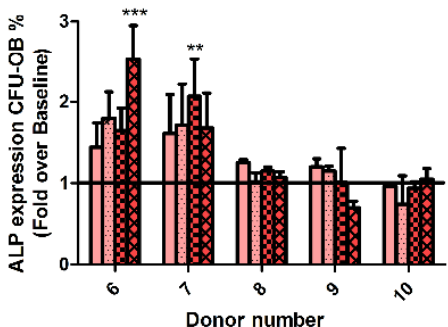

Average

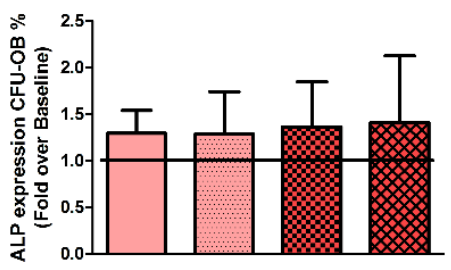

C
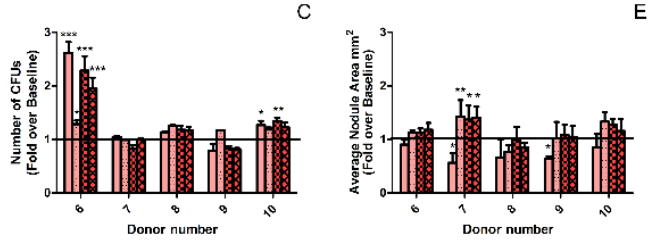

E
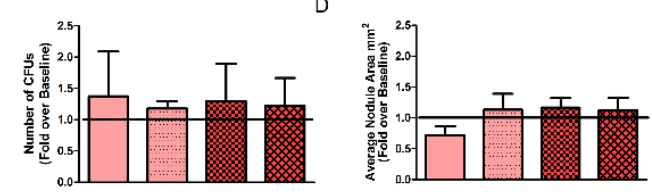

Oil red O (Adipogenesis)
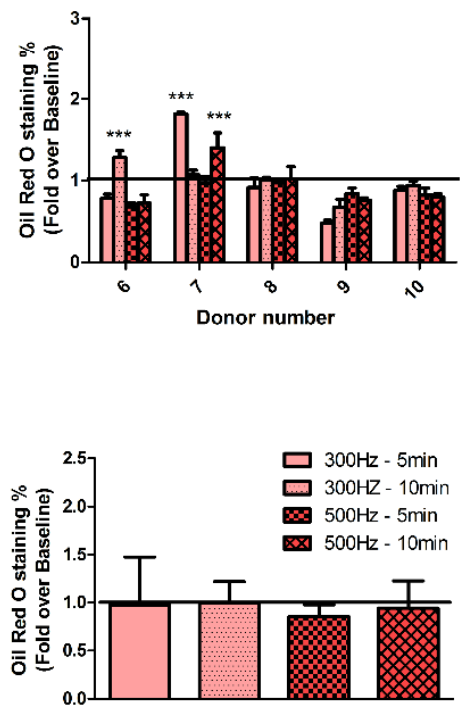

Figure 5. Biological characterisation of isolated hMSCs from acoustically stimulated BM at 300 and $500 \mathrm{~Hz}$ for five and 10 minutes. The results are presented as the fold change over the non-stimulated BM (baseline). (A) Proliferation of hMSCs calculated as PD/day from P1 to P2, donor and stimulation dependent. (B) Proliferation average. (C) $C F U$ potential of hMSCs, donor and stimulation dependent. (D) CFU average. (E) ECM production, quantification of nodule size area in $\mathrm{mm}^{2}$, donor and stimulation dependent. (F) ECM production average. (G) Osteogenic potential calculated as percentage of ALP positive colonies within the CFUs, donor and stimulation dependent. (H) Osteogenesis average. (I) Adipogenic potential, quantification of Oil Red O staining relative to $100 \%$ Oil Red O staining solution, donor and stimulation dependent. (J) Adipogenesis average. Values are represented as the mean \pm standard deviation of at least three independent experiments $(n \geq 3)$. Statistically significant differences were found with $* * * p<0.001,{ }^{* *} p<0.01$ and ${ }^{*} p<0.05$. 
condition) between the isolation conditions. A trend in higher expression of CD105 (p $=0.28)$, CD73 ( $p=0.57)$, and CD146 ( $p=0.66)$ was observed, however, in the hMSCs isolated in SF media when compared with the heterogeneous condition (Supplementary Figure 5). The high standard deviation is the result of inter-donor variation.

\section{Discussion}

The human body has an extensive capacity to regenerate bone tissue following trauma. Large defects cannot be restored without intervention, however, and often lead to nonunion. Long bone fracture repair has been extensively studied at both clinical as well as fundamental research level; however, little is known about the differences in fracture repair between the femur and the tibia [6, 7]. Therefore, the aim of the present study was to assess the pool and biological functions of BM-derived hMSCs in the lower limbs, such as the ilium, proximal femur, distal femur, and proximal tibia. Additionally, we broadened our research interest towards methods to prime BM-derived hMSCs for later reimplantation at the fracture site. This should facilitate their homing and commitment towards quicker bone regeneration; it has already been shown that a reduced pool of proliferative and multipotent hMSCs are present at low healing fractures [23].

We showed that the pool of BM-derived hMSCs differ with respect to BM aspiration location. We found that after 14 days, the number of hMSCs isolated from the ilium and proximal femur was higher (Figure 2B), and they showed higher self-renewal and osteogenic differentiation potential (Figure 3D, F) in comparison with hMSCs isolated from the distal femur and proximal tibia, with the latter showing higher adipogenic potential. These findings correspond to the macroscopic appearance of the BM, as described by Malkiewicz et al. [24], with red BM found in the ilium and proximal femur, suggesting an active participation to hematopoiesis; and yellow BM found in the distal femur and proximal tibia, containing a considerable admixture of fat. During ageing, red marrow is replaced by yellow marrow, and this change in the marrow compartment might differ in fracture repair rates [24]. In this context, we strongly believe that the differences in BFH rate between the femur and tibia are the result of insufficient amounts of hMSCs present at the fracture site, as well as their poor selfrenewal and osteogenic ability. Additionally, previous studies demonstrated the use of $\mathrm{BM}$ aspirate and its efficacy in the treatment of fracture nonunion or high nonunion rate repair [25, 26]. Therefore, we propose that the isolation of BM from the ilium, and its delivery in tibial fractures to enhance bone healing, could improve the current clinical treatment strategy.

In the process of quantifying the concentration of MNCs regarding the aspirated BM volume, we found that $10 \mathrm{ml}$ of BM yields the highest MNC concentration. Higher BM volumes yielded low concentrations of MNCs, due to dilution with peripheral blood during aspiration; while lower BM volumes also yielded lower concentration of MNCs, as described by Fennema EM et al. [27]. Interestingly, in both studies, the same average 
Proliferation

A

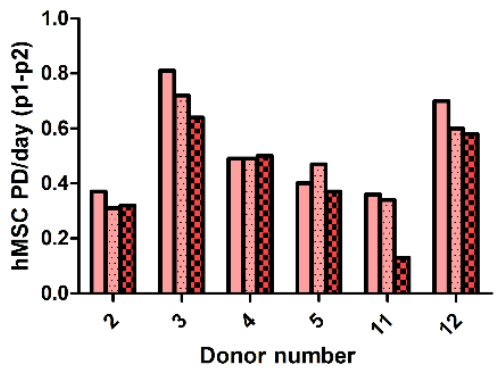

ECM production

C

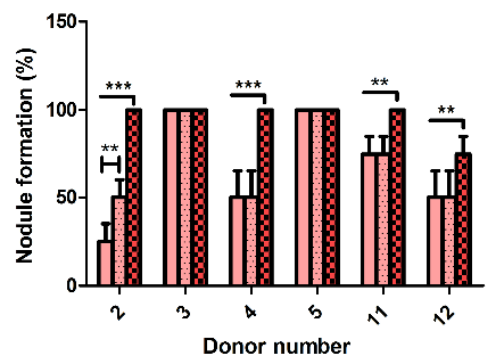

Oil red $\mathrm{O}$ (Adipogenesis)

E

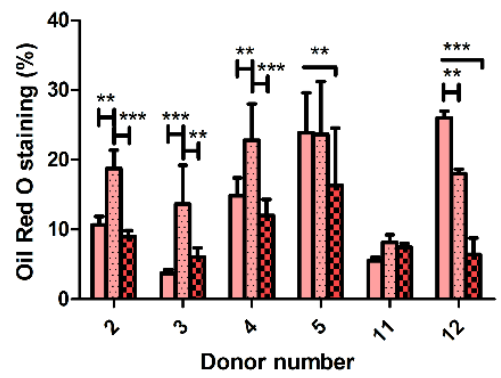

Average

B

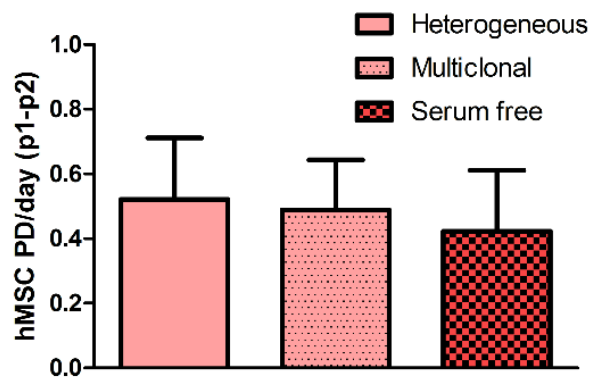

Average

D

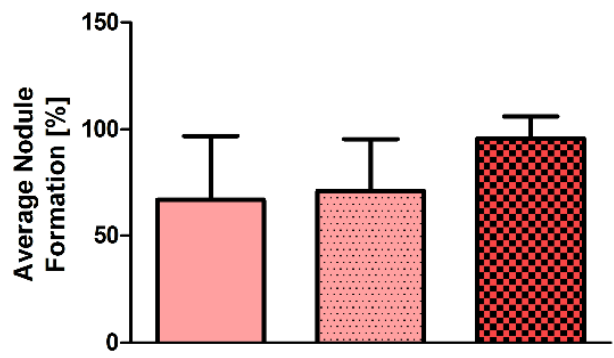

Average

F

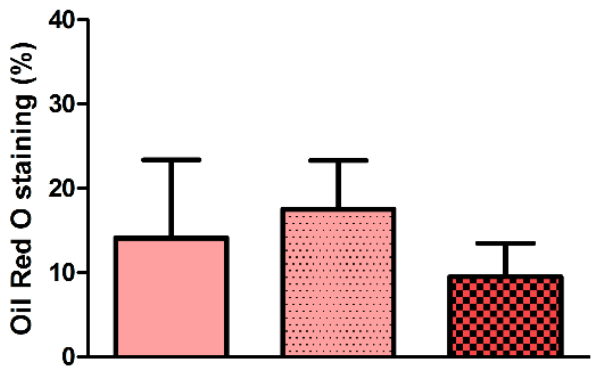

Figure 6. Biological characterisation of hMSCs isolated from BM under different isolation procedures (A) Proliferation of hMSCs calculated as PD/day from P1 to P2, donor and isolation procedure dependent. (B) Proliferation average. (C) ECM production, percentage of formed nodules, donor and isolation procedure dependent. (D) ECM production average. (E) Adipogenic potential, quantification of Oil Red $O$ staining relative to $100 \%$ Oil Red $O$ staining solution, donor and isolation procedure dependent. (F) Adipogenesis average. Values are represented as the mean \pm standard deviation of at least three independent experiments $(n \geq 3)$. Statistically significant differences were found with $* * * p<0.001$ and ${ }^{* *} p<0.01$. 
concentration of MNCs $\left(2.6^{*} 10^{7} \mathrm{MNCs} / \mathrm{ml}\right)$ was found at $10 \mathrm{ml}$ aspirated BM, henceforth encouraging the surgeons to limit the aspirated BM volume from the ilium to $10 \mathrm{ml}$.

To increase the contribution of cells to bone repair, a new dynamic vision emerged in tissue regeneration, focusing on rhythms and oscillatory patterns capable of orchestrating cell fate decision. The use of physical energy, such as ultrasound vibration, has shown to affect cell fate and increase the rate of bone repair [7, 28, 29]; however, at insufficient cell numbers the therapy has been rather inefficient (tibia) [6]. Therefore, we propose a different approach: the delivery of acoustically stimulated BM from the ilium (rich in hMSCs) at the fracture site. Based on a previous study by Ridgway, J. et al., where acoustic vibration was used to separate cells from BM suspension, by trapping the cells in the pressure node planes of the standing wave and reducing the volume, an increase in CFU-Ob potential was observed in the processed $\mathrm{BM}$ [22]. We believe that this increase was not only resulted in BM volume reduction, but also a change in cell fate. To test this, we selected two different frequencies in the range of acoustic vibration, 300 and $500 \mathrm{~Hz}$, and two time points: five and 10 minutes. The results showed a trend towards an increased self-renewal, ECM production, and a shift towards osteogenic but not adipogenic differentiation in acoustically stimulated $\mathrm{BM}$, suggesting that hMSCs may sense the acoustic vibratory frequencies. The long expansion period necessary to obtain sufficient cell numbers to perform the assays eventually led to a decrease in the multilineage potential, however, because cell potential is known to diminish with increased in vitro culture time [30,31]. In addition, we speculate that the decrease in positive hMSCs surface markers in acoustically stimulated BM is the result of integrin reorganisation (cellular mechanoreceptor on the cell surface), followed by surface marker reorganisation [32] and a change in cell fate. To our knowledge, this is the first study where acoustic energy was applied directly to $\mathrm{BM}$ and not on cultured cells, paving the way to its implementation into a one-step surgical procedure for bone repair. The harvested BM can be first exposed to acoustic stimulation during surgery in the sterile field. After this short period of cell manipulation, the suspension of BM components can be simply administrated to the location of interest, either in the initial treatment of high risk cases or in revision surgery for pseudarthrosis.

While acoustic sound vibration focuses on changing the phenotype of the cells, variation of the initial hMSCs isolation conditions focuses on the selection of a defined cell pool. We found that isolation of hMSCs in SF media selects a pro-ECM cell population, which could be of great help in accelerating the rebuilding process of a native ECM following a bone fracture. Additionally, we found that isolation of hMSCs at a reduced MNC plating number selects a pro-adipogenic cell population. These findings underline the importance of carefully selecting the right isolation procedure for the right application. 


\section{CONCLUSION}

Overall, our results suggest that novel approaches to BFH can be developed based on our improved understanding of BM cell biology. Based on our results, we hypothesise that poor BFH in the tibia might be the result of insufficient cell numbers, as well as their poor osteogenic potential. Based on this, we suggest the aspiration of BM from the ilium and its delivery into the tibia to accelerate fracture healing. Moreover, we proposed two new possible therapeutic approaches for BFH: acoustic stimulation of BM and use of preselected pro-ECM hMSCs pool for delivery at the fracture site.

\section{ACKNOWLEDGEMENTS}

We would like to acknowledge the orthopaedic department at Medisch Centrum Twente for the collection of BM; Smith \& Nephew for the financial support to perform this research; as well as its collaborators, A Au, C Wan, T Kapur, and JN Ridgway for their support and design of the acoustic stimulation device.

\section{Abbreviations}

human mesenchymal stromal cells (hMSCs); bone marrow (BM); bone fracture healing (BFH); mononuclear cells (MNCs); serum free (SM); total hip arthroplasty (THA); total knee arthroplasty (TKA); fetal bovine serum (FBS), growth media (GM); $\alpha$-minimal essential media ( $\alpha$-MEM); population doubling (PD); passage 1 (P1); passage 2 (P2); colony forming unit (CFU); colony forming unit osteoblast (CFU-Ob); $\beta$ glycerophosphate (BGP); dexamethasone (Dex); alkaline phosphatase (ALP), extracellular matrix (ECM). 


\section{SUPPLEMENTARY FIgURES}

\section{Please note: cluster of figures (1, 3 and 5)}

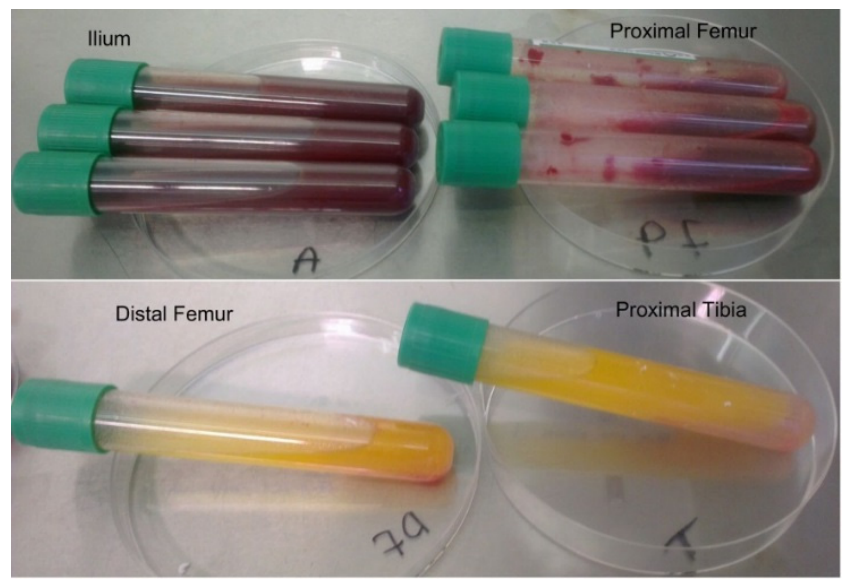

Supplementary Figure 1. Example of bone marrow aspirated from different locations: ilium, proximal femur, distal femur, and proximal tibia.
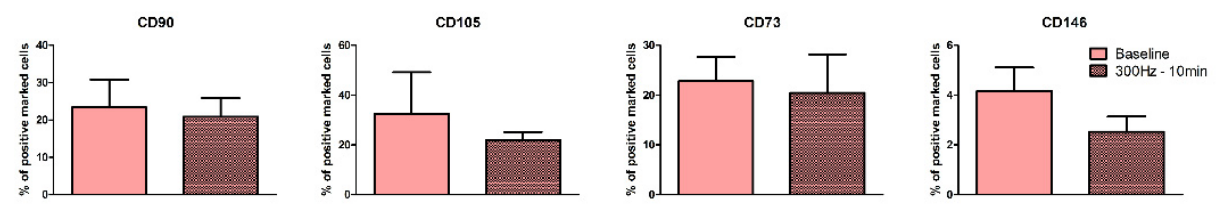

Supplementary Figure 3. Surface marker expression (in percentage) of the acoustically stimulated cells represented as a bar plot; each bar stands for the average across the percentage of surface markers obtained from three donors. The selected sets of cell surface markers expressed positive on hMSC. All the other investigated sets expressed negative for both conditions, and are therefore not shown. Not statistically significant differences were found between the two conditions.

Surface marker expression

CD90

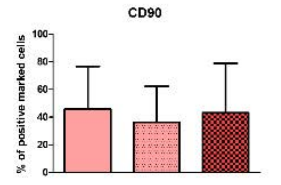

CD105

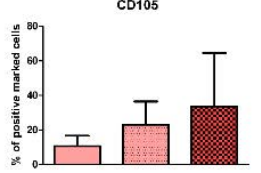

$\mathrm{CD} 73$

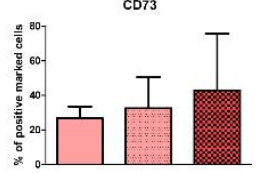

CD146

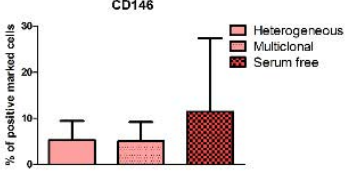

Supplementary Figure 5. Surface marker expression (in percentage) of the varying culture conditions represented as a bar plot; each bar stands for the average over the percentage of surface markers obtained from three donors. The selected sets of cell surface markers expressed positive on hMSC. All the other investigated sets expressed negative for both conditions, and are therefore not shown. No statistically significant differences were found between the three conditions. 
$\mathrm{BM}$ volumes

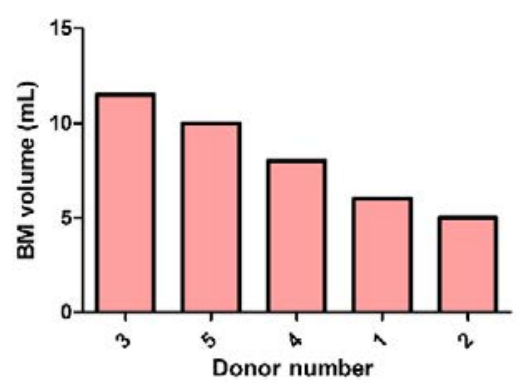

CFU

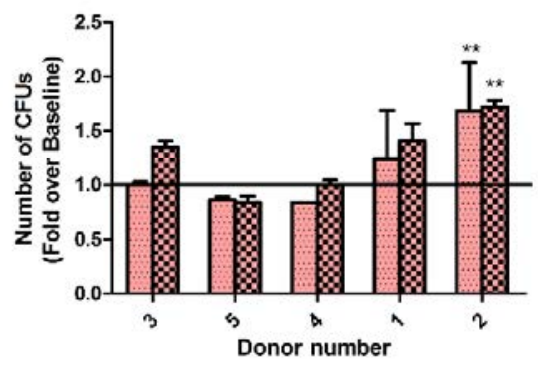

CFU-Ob (Osteogenesis)

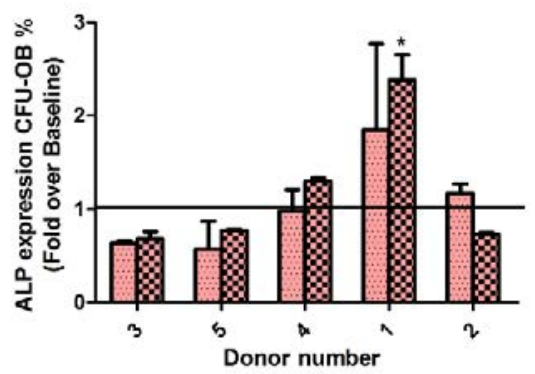

Proliferation

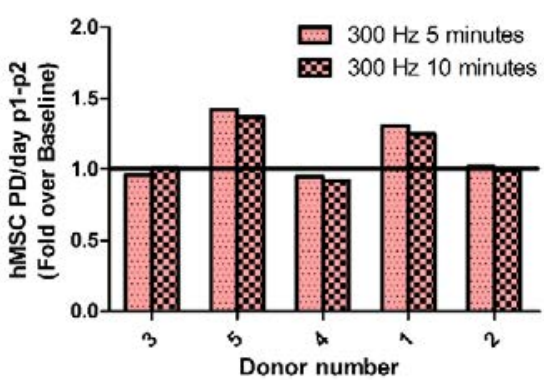

ECM production

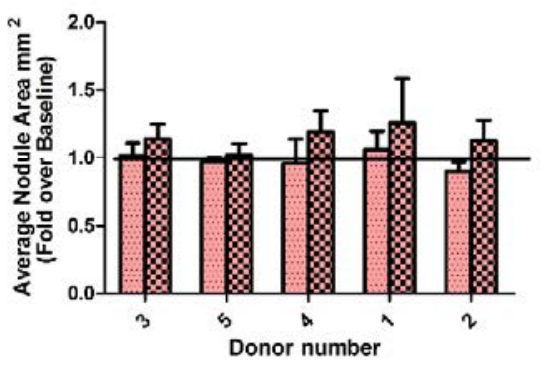

Oil red O (Adipogenesis)

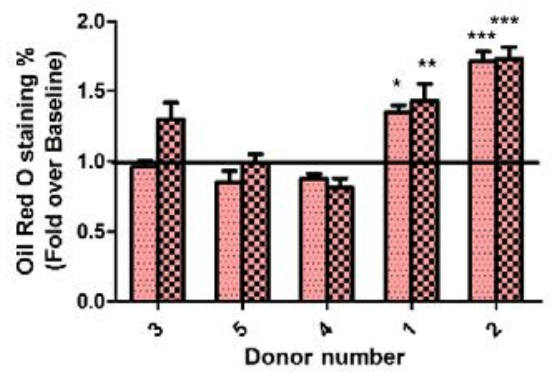

Supplementary Figure 2. Biological characterisation of isolated hMSCs from acoustically stimulated $\mathrm{BM}$ at $300 \mathrm{~Hz}$ for five minutes at different volumes, 11.5, 10, 8, 6, and 5ml. The results are presented as the fold change over the non-stimulated BM (baseline). (A) Graphic representation of the BM volumes, donor dependent. (B) Proliferation of hMSCs calculated as $\mathrm{PD}$ /day from $\mathrm{P} 1$ to $\mathrm{P} 2$, donor and volume dependent. (C) CFU potential of hMSCs, donor and volume dependent. (D) ECM production, quantification of nodule size area in $\mathrm{mm}^{2}$, donor and volume dependent. (E) Osteogenic potential calculated as percentage of ALP positive colonies within the CFUs, donor and volume dependent. (F) Adipogenic potential, quantification of Oil Red O staining relative to $100 \%$ Oil Red O staining solution, donor and volume dependent. Values are represented as the mean \pm standard deviation of at least three independent experiments $(n \geq 3)$. Statistically significant differences were found with $* * * p<0.001, * * p<0.01$ and $* p<0.05$. 


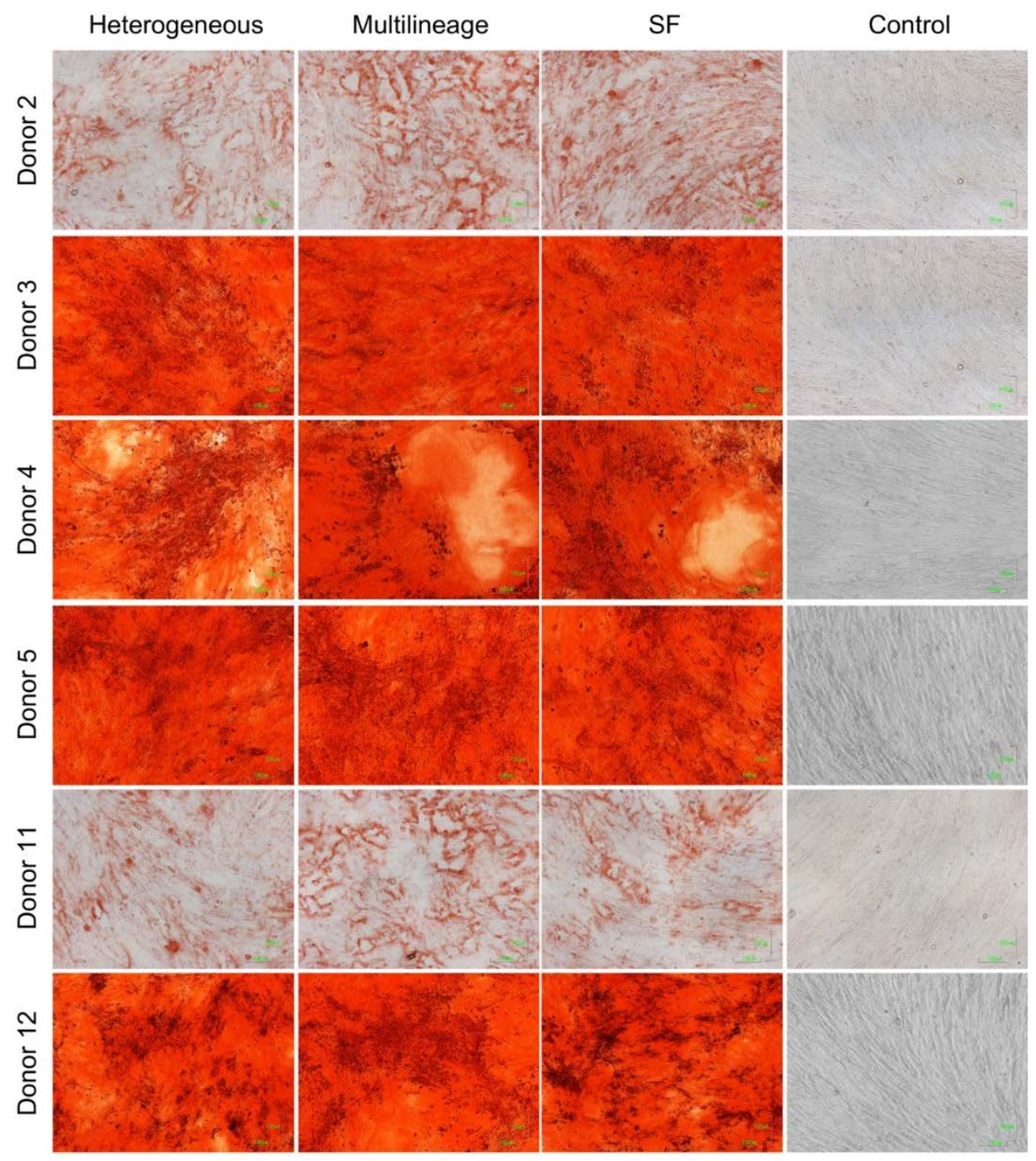

Supplementary Figure 4. Alizarin red staining of calcium nodules after osteogenic induction of hMSC isolated under varying culture condition from different donors. No differences were observed between the culture conditions, though differences between the donors were identified. Donor 2 and 11 showed less calcium nodule formation than the rest of the donors. All the controls stained negative for calcium nodules formation. Values are represented as the mean \pm standard deviation of at least three independent experiments $(n=$ $3)$. 


\section{SUPPLEMENTARY TABLES}

\begin{tabular}{ll}
\hline BM location comparison & P value \\
\hline Ilium vs. proximal femur & 0.36 \\
Ilium vs. distal femur & 0.07 \\
Ilium vs. proximal tibia & 0.12 \\
Proximal femur vs. distal femur & 0.86 \\
Proximal femur vs. proximal tibia & 0.94 \\
Distal femur vs. proximal tibia & 0.99 \\
\hline
\end{tabular}

Supplementary Table 1. Testing the significance of difference in number of hMSCs isolated from different BM aspiration locations. The identified $p$ value is presented after performing a one-way ANOVA and Tukey's multiple comparison test.

\begin{tabular}{lll}
\hline Experiment & BM location comparison & P value \\
\hline CFU & Ilium vs. proximal femur & 0.45 \\
& Ilium vs. distal femur & 0.72 \\
& Ilium vs. proximal tibia & 0.87 \\
& Proximal femur vs. distal femur & 0.07 \\
& Proximal femur vs. proximal tibia & 0.13 \\
CFU-Ob & Distal femur vs. proximal tibia & 0.99 \\
& Ilium vs. proximal femur & 0.76 \\
& Ilium vs. distal femur & 0.1 \\
& Ilium vs. proximal tibia & 0.21 \\
& Proximal femur vs. distal femur & 0.5 \\
& Proximal femur vs. proximal tibia & 0.73 \\
& Distal femur vs. proximal tibia & 0.98 \\
\hline
\end{tabular}

Supplementary Table 2. Testing the significance of difference in CFUs and $\mathrm{CFU}-\mathrm{Ob}$ from different BM aspiration locations. The identified $p$ value is presented after performing a one-way ANOVA and Tukey's multiple comparison test.

\begin{tabular}{lll}
\hline Experiment & Cell culture condition & P value \\
\hline Proliferation & Heterogenous vs. multiclonal & 0.94 \\
& Heterogenous vs. serum free & 0.62 \\
& Multiclonal vs. serum free & 0.81 \\
ECM production & Heterogenous vs. multiclonal & 0.95 \\
& Heterogenous vs. serum free & 0.11 \\
& Multiclonal vs. serum free & 0.18 \\
Oil Red O & Heterogenous vs. multiclonal & 0.66 \\
(Adipogenesis) & & \\
& Heterogenous vs. serum free & 0.48 \\
& Multiclonal vs. serum free & 0.13 \\
\hline
\end{tabular}

Supplementary Table 3. Testing the significance in proliferation, ECM production, and adipogenesis of different hMSCs isolation and cell culture conditions. The identified $p$ value is presented after performing a one-way ANOVA and Tukey's multiple comparison test. 


\section{REFERENCES}

1. Steiner C, Andrews R, Barrett M, Weiss A: HCUP Projections: mobility/orthopedic procedures 2011 to 2012. In: HCUP projections report 2012-03 US Agency for Healthcare Research and Quality website. www.hcupus.ahrq.gov/reports/projections/2012-03.pdf.; 2012.

2. $\quad$ Einhorn TA: Enhancement of fracture-healing. J Bone Joint Surg Am 1995, 77(6):940-956.

3. Claes L, Willie B: The enhancement of bone regeneration by ultrasound. Progress in biophysics and molecular biology 2007, 93(1-3):384-398.

4. Jingushi S, Mizuno K, Matsushita T, Itoman M: Low-intensity pulsed ultrasound treatment for postoperative delayed union or nonunion of long bone fractures. J Orthop Sci 2007, 12(1):35-41.

5. Caplan AI: Mesenchymal Stem Cells: Cell-Based Reconstructive Therapy in Orthopedics. Tissue Engineering 2005, 11(7-8):1198-1211.

6. Fong K, Truong V, Foote CJ, Petrisor B, Williams D, Ristevski B, Sprague S, Bhandari M: Predictors of nonunion and reoperation in patients with fractures of the tibia: an observational study. BMC musculoskeletal disorders 2013, 14:103.

7. Society COT: Nonunion following intramedullary nailing of the femur with and without reaming. Results of a multicenter randomized clinical trial. J Bone Joint Surg Am 2003, 85-A(11):2093-2096.

8. Hernigou P, Mathieu G, Poignard A, Manicom O, Beaujean F, Rouard H: Percutaneous autologous bone-marrow grafting for nonunions. Surgical technique. J Bone Joint Surg Am 2006, 88 Suppl 1 Pt 2:322-327.

9. Kitoh H, Kawasumi M, Kaneko H, Ishiguro N: Differential effects of culture-expanded bone marrow cells on the regeneration of bone between the femoral and the tibial lengthenings. Journal of pediatric orthopedics 2009, 29(6):643649.

10. El-Mowafi H, Mohsen M: The effect of low-intensity pulsed ultrasound on callus maturation in tibial distraction osteogenesis. International orthopaedics 2005, 29(2):121-124.

11. Leung KS, Lee WS, Tsui HF, Liu PP, Cheung WH: Complex tibial fracture outcomes following treatment with lowintensity pulsed ultrasound. Ultrasound in medicine \& biology 2004, 30(3):389-395.

12. Heckman JD, Ryaby JP, McCabe J, Frey JJ, Kilcoyne RF: Acceleration of tibial fracture-healing by non-invasive, lowintensity pulsed ultrasound. J Bone Joint Surg Am 1994, 76(1):26-34.

13. Gebauer D, Mayr E, Orthner E, Ryaby JP: Low-intensity pulsed ultrasound: effects on nonunions. Ultrasound in medicine \& biology 2005, 31(10):1391-1402.

14. Gold SM, Wasserman R: Preliminary results of tibial bone transports with pulsed low intensity ultrasound (Exogen). Journal of orthopaedic trauma 2005, 19(1):10-16.

15. Nikukar H, Reid S, Tsimbouri PM, Riehle MO, Curtis AS, Dalby MJ: Osteogenesis of mesenchymal stem cells by nanoscale mechanotransduction. ACS nano 2013, 7(3):2758-2767.

16. Digirolamo CM, Stokes D, Colter D, Phinney DG, Class R, Prockop DJ: Propagation and senescence of human marrow stromal cells in culture: a simple colony-forming assay identifies samples with the greatest potential to propagate and differentiate. British journal of haematology 1999, 107(2):275-281.

17. Colter DC, Class R, DiGirolamo CM, Prockop DJ: Rapid expansion of recycling stem cells in cultures of plasticadherent cells from human bone marrow. Proceedings of the National Academy of Sciences of the United States of America 2000, 97(7):3213-3218.

18. Sekiya I, Colter DC, Prockop DJ: BMP-6 enhances chondrogenesis in a subpopulation of human marrow stromal cells. Biochemical and biophysical research communications 2001, 284(2):411-418.

19. Sacchetti B, Funari A, Michienzi S, Di Cesare S, Piersanti S, Saggio I, Tagliafico E, Ferrari S, Robey PG, Riminucci M et al: Self-renewing osteoprogenitors in bone marrow sinusoids can organize a hematopoietic microenvironment. Cell 2007, 131(2):324-336. 
20. Mentink A, Hulsman M, Groen N, Licht R, Dechering KJ, van der Stok J, Alves HA, Dhert WJ, van Someren EP, Reinders MJT et al: Predicting the therapeutic efficacy of MSC in bone tissue engineering using the molecular marker CADM1. Biomaterials 2013, 34(19):4592-4601.

21. Both SK, van der Muijsenberg Aj Fau - van Blitterswijk CA, van Blitterswijk Ca Fau - de Boer J, de Boer J Fau - de Bruijn JD, de Bruijn JD: A rapid and efficient method for expansion of human mesenchymal stem cells. (1076-3279 (Print)).

22. Ridgway J, Butcher A, Chen PS, Horner A, Curran S: Novel technology to provide an enriched therapeutic cell concentrate from bone marrow aspirate. Biotechnology progress 2010, 26(6):1741-1748.

23. Seebach C, Henrich D, Tewksbury R, Wilhelm K, Marzi I: Number and proliferative capacity of human mesenchymal stem cells are modulated positively in multiple trauma patients and negatively in atrophic nonunions. Calcified tissue international 2007, 80(4):294-300.

24. Malkiewicz A, Dziedzic M: Bone marrow reconversion - imaging of physiological changes in bone marrow. Polish journal of radiology / Polish Medical Society of Radiology 2012, 77(4):45-50.

25. Hernigou P, Poignard A, Beaujean F, Rouard H: Percutaneous Autologous Bone-Marrow Grafting for Nonunions. Influence of the Number and Concentration of Progenitor Cells 2005, 87(7):1430-1437.

26. Murawski CD, Kennedy JG: Percutaneous internal fixation of proximal fifth metatarsal jones fractures (Zones II and III) with Charlotte Carolina screw and bone marrow aspirate concentrate: an outcome study in athletes. The American journal of sports medicine 2011, 39(6):1295-1301.

27. Fennema EM, Renard AJ, Leusink A, van Blitterswijk CA, de Boer J: The effect of bone marrow aspiration strategy on the yield and quality of human mesenchymal stem cells. Acta orthopaedica 2009, 80(5):618-621.

28. Choi WH, Choi BH, Min BH, Park SR: Low-intensity ultrasound increased colony forming unit-fibroblasts of mesenchymal stem cells during primary culture. Tissue engineering Part C, Methods 2011, 17(5):517-526.

29. Angle SR, Sena K, Sumner DR, Virdi AS: Osteogenic differentiation of rat bone marrow stromal cells by various intensities of low-intensity pulsed ultrasound. Ultrasonics 2011, 51(3):281-288.

30. Tolar J, Nauta AJ, Osborn MJ, Panoskaltsis Mortari A, McElmurry RT, Bell S, Xia L, Zhou N, Riddle M, Schroeder TM et al: Sarcoma derived from cultured mesenchymal stem cells. Stem Cells 2007, 25(2):371-379.

31. Li H, Fan X, Kovi RC, Jo Y, Moquin B, Konz R, Stoicov C, Kurt-Jones E, Grossman SR, Lyle S et al: Spontaneous expression of embryonic factors and p53 point mutations in aged mesenchymal stem cells: a model of age-related tumorigenesis in mice. Cancer research 2007, 67(22):10889-10898.

32. Yang RS, Lin WL, Chen YZ, Tang CH, Huang TH, Lu BY, Fu WM: Regulation by ultrasound treatment on the integrin expression and differentiation of osteoblasts. Bone 2005, 36(2):276-283. 



\section{Chapter 4}

\section{Human muscle-derived factors accelerate ACL graft healing: an in vitro and in vivo analysis}

Ghebeş C.A., Groen N., Cheuk Y.C., Fu S.C., Fernandes H.A.M. and Saris D.B.F. 


\section{Abstract}

One of the ligaments most often damaged during sports - the anterior cruciate ligament $(A C L)$ - has poor healing capacity. Upon damage, reconstructive surgery is performed to restore the mechanical stability of the knee and to reduce the inflammatory milieu otherwise present in the joint. A return to normal activities, however, takes between 9 and 12 months. Thus, strategies capable of accelerating/improving ACL graft healing are needed.

Embryonic development of tendon and ligament $(T / L)$ is regulated by a crosstalk between different cell types. Using an indirect co-culture system, we discovered that myoblast-derived signals - but not osteoblasts, chondrocytes, or stromal-derived signals - are capable of upregulating classical T/L markers such as Scleraxis and Tenomodulin on human hamstring tendon-derived cells (hTC), which contribute to ACL graft healing. Whole transcriptome analysis showed that co-culturing hTC with myoblasts led to an upregulation of extracellular matrix (ECM) genes and resulted in enhanced ECM deposition. In vivo, using a rat model of ACL reconstruction, showed that conditioned media derived from human muscle tissue accelerated femoral tunnel closure, a key step for autograft integration. Collectively, these results indicate that muscle-derived signals can be employed to improve ACL graft healing in a clinical setting where muscle remnants are often discarded. 


\section{INTRODUCTION}

The anterior cruciate ligament (ACL) is one of the most often damaged ligaments in the knee and, unfortunately, has very limited healing capacity, leaving surgical reconstruction as the only therapeutic option. More than 200,000 ACL reconstructions are performed annually in the United States alone [1]. A commonly used graft to replace the original ACL and restore its function is the hamstring tendon, which, in comparison with the bone-patellar tendon-bone graft, gained popularity due to its accessibility, reduced pain, and lower morbidity rates [2].

Following an ACL reconstruction, the mechanical stability of the knee joint is readily restored by means of fixation of the graft into the bone, while the necessary biological properties for long-term maintenance lag behind. In particular, vascularisation, extracellular matrix (ECM) deposition, and integration of the soft tissue into the bone are key limiting steps in the regenerative process. Thus, improving at least one of these processes will contribute to ameliorating the recovery period and improving the patient's quality of life.

In a recent review, Schweitzer et al. discuss the findings that highlight the musculoskeletal assembly in the vertebrate embryo, findings that emphasise the reciprocal interactions between the forming tendons, muscle, and cartilage tissue. Accordingly, the formation of complex tissues during embryonic development requires a continuous bidirectional communication between cells of different origins, such as muscle and tendon, or cartilage and tendon, to allow precise tissue assembly [3].

Based on the abovementioned, we hypothesised that co-culturing human hamstring tendon-derived cells - the cells present in the most commonly used autograft for ACL reconstruction - with myoblast-, osteoblast-, chondrocyte-, or stromal-derived cells could enhance the expression of tendon and ligament (T/L) markers and contribute to accelerating the healing process.

To test this, we used an in vitro indirect co-culture system using transwell chambers where we cultured human tendon-derived cells (hTC) in the presence of the different cell types and investigated the expression of several T/L markers firstly by qPCR and later using whole transcriptome and secretome analysis. Our results clearly indicate the co-culturing hTC with myoblast or human muscle tissue (hMT)-derived condition media (CM) significantly increases the expression of T/L markers, ultimately leading to an increase in ECM deposition in vitro. Based on these findings we used an in vivo rat model of an ACL injury and, as expected, demonstrated that human muscle-CM accelerated femoral tunnel closure. A schematic representation of the experimental design is presented in Figure 1. 


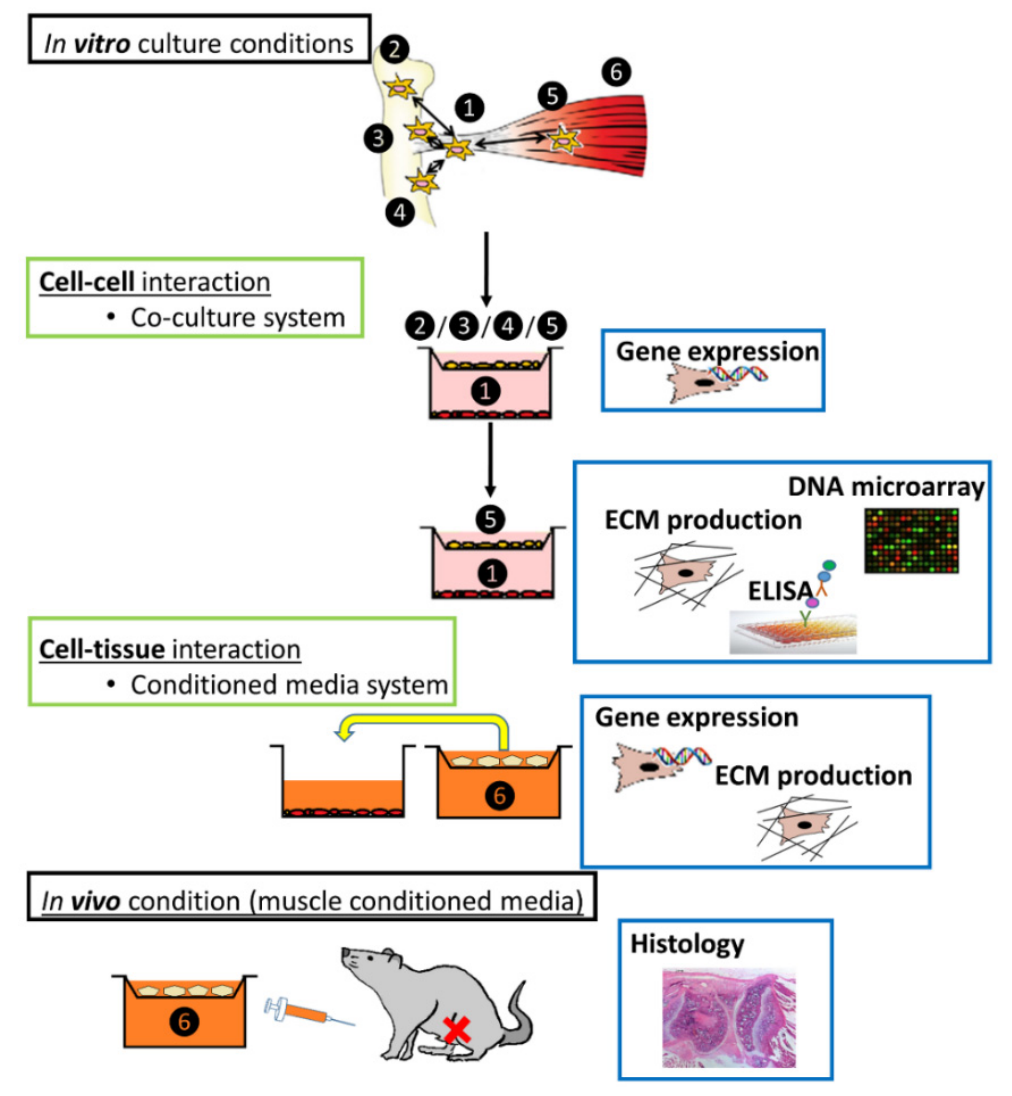

Figure 1. Schematic overview of the experimental design. The number represents different type of cells or tissue: 1 hTC, 2 BM-hMSC, 3 chondrocytes, 4 osteoblasts, 5 myoblasts, 6 muscle tissue.

\section{MATERIAL AND METHODS}

\section{Cell culture}

Samples of human hamstring tendon, cartilage harvested from tibial/femoral ends, and bone marrow (BM) harvested from ilium were obtained from patients undergoing ACL reconstruction, knee replacement, or total hip arthroplasty, respectively. Cell isolation was carried out within 24 hours of procurement, as previously described [4-6]. The collection and anonymous use of the tissues and BM was approved and performed according to the medical ethical regulations and the guideline 'good use of redundant tissue for research' of the Dutch Federation of Medical Research Societies (Ref. no.: K13-46). Patients provided informed consent after being provided with a verbal explanation and an opportunity for questioning. 
C2C12 (myoblast), MC3T3 (osteoblast), and ATDC5 (chondrocyte) mouse cell lines were obtained from American Type Culture Collection and cultured according to standard mammalian tissue culture protocols and sterile technique [7-9].

Cells were expanded in basic media consisting of $\alpha$-minimal essential media ( $\alpha \mathrm{MEM}$, Life Technologies); 10\% fetal bovine serum (FBS, Lonza); $0.2 \mathrm{mM} \mathrm{L-ascorbic} \mathrm{acid} \mathrm{2-}$ phosphate magnesium salt (ASAP, Sigma); 100 units/mL penicillin (Gibco); and 100 $\mathrm{mg} / \mathrm{ml}$ streptomycin (Gibco). Primary cells were never used beyond passage 4 .

\section{Indirect cell co-culture system}

An in vitro commercially available biocompartment culture system was used (1 $\mu \mathrm{m}$ pore size; Greiner Bio-One) to allow for an indirect exchange of humoral factors between the different cell types. In brief, hTCs were seeded onto the 6-well outer tissue culture plate, while bone marrow-derived human mesenchymal stromal cells (BMhMSC) or mouse myoblasts, chondrocytes, and osteoblasts were seeded on the inner culture insert, at 100,000 cells per well/insert at a ratio of 1:1 and in triplicate. The cells were cultured for one day in basic medium to allow an efficient cell attachment, after which the media was changed to serum reduced media (SRM) consisting of basic media with $1 \%$ FBS, rather than the abovementioned 10\%. Media were refreshed every 3-4 days until the end of the experiment.

\section{Conditioned media collection and use}

hMT harvested from patients undergoing ACL reconstruction (remnant hamstring muscle) was washed in PBS, minced into small pieces, and plated on non-tissue culture treated 6-well plate at approximately $2 \mathrm{~g}$ tissue/plate in SRM. Condition medium (CM) was collected at day 3 and 7 and passed through a $100 \mu \mathrm{m}$ filter. One day prior to the collection of hMT CM, hTCs were plated at 100,000 cells/well on tissue culture 6-well plates in triplicate. The next day, half of the media were replaced with hMT CM and SRM and media were refreshed every three days until the end of the experiment.

\section{RNA isolation and qRT-PCR assessment}

Total RNA was isolated from hTCs using the NucleoSpin RNA II isolation kit (Macherey-Nagel), per the manufacturer's instructions. RNA was collected in RNasefree water and a quantitative analysis was performed using spectrophotometry (Nanodrop). First-strand cDNA was synthesised from $800 \mathrm{ng}$ total RNA/sample using iScript (BioRad) per the manufacturer's instructions. qPCR was performed on a realtime PCR detection system (Biorad) using iQ Syber green supermix (BioRad) for a panel of primers, described in Supplementary Table 1, or using TaqMan Universal MasterMix for beta-2-microglobulin (B2M) and scleraxis (SCX). Gene expression was normalised to the reference gene B2M and fold induction calculated using the $\Delta \Delta \mathrm{Ct}$ method. 


\section{Microarray expression profiling}

Gene expression profiling of two hTC donors cultured in triplicate in the absence or presence of mouse myoblasts was carried out using the Illumina microarray platform. cRNA was synthesised from 750 ng of total RNA using the Illumina TotalPrep RNA amplification kit (Ambion) per the manufacturer's instruction, and cRNA quality was assessed using Bioanalyser 2100 (Agilent). Next, cRNA was hybridised on Illumina HT-12 v4 expression beadchips overnight, after which the array was washed and blocked. Then, by adding streptavidin Cy-3, a fluorescent signal was developed and the arrays were scanned on an Illumina Beadarray reader and raw intensity values were background corrected in BeadStudio (Illumina). Further data processing and statistical testing were performed using $\mathrm{R}$ and Bioconductor statistical software [10]. The probelevel raw intensity values were quantile normalised and transformed using variance stabilisation (VSN). A linear modelling approach with empirical Bayesian methods, as implemented in the Limma package [11], was applied for differential expression analysis of the resulting probe-level expression values. $\mathrm{P}$ values were corrected for multiple testing using the Benjamini and Hochberg method [12]. Genes were considered differentially expressed between hTC cultured in the presence of myoblasts and hTC cultured alone, when a corrected p value below 0.05 was reached with an absolute logfold change above 0.5. A venn diagram (using Venny 2.1.0 BioinfoGP online tool) was used to represent the overlapping genes between the different conditions and donors. The differentially expressed genes (combining both up- and down-regulated genes) overlapping between both donors were subjected to Gene Ontology (GO) analysis using DAVID bioinformatics resources $[13,14]$. The GO terms were considered significantly overrepresented when a Benjamini-Hochberg corrected p value of 0.05 was reached.

\section{Collagen content assessment}

hTCs were co-cultured with myoblasts or hMT CM for 29 days and media were refreshed every three days, as previously described. At day 29, the cells were fixed in $10 \%(\mathrm{v} / \mathrm{v})$ buffered formalin for 15 minutes at room temperature and stained for collagen deposition using Picrosirius red staining kit (Polyscience Inc.), following the manufacturer's instructions. Images of the stained cells were acquired using a Nikon bright field microscope and quantification was performed using FIJI open source software. Images were converted to 8-bit and background subtracted using rolling ball radius function. The image was then converted into binary, the area of Picrosirius red staining was selected and measured in total number of pixels.

\section{ELISA}

The supernatant of co-cultured hTCs and myoblasts cultured on SRM for three days was collected and immediately processed to assess the secretion of a panel of 23 cytokines and growth factors using ELISA plate array I for profiling 23 mouse cytokine proteins (BioCat), following the manufacturer's instructions. 


\section{$A C L$ reconstruction in rat}

The animal experiments were approved and performed in strict accordance with the recommendations and guidelines of the Animal Experimentation Ethics Committee in The Chinese University of Hong Kong (Ref. no.: 15-166-MIS). ACL reconstruction was performed in 15 male Sprague Dawley rats (12 weeks old) on the right knee using ipsilateral flexor digitorum longus tendon, as previously described [15]. Under general anaesthesia with ketamine and xylazine (75 and $25 \mathrm{mg} / \mathrm{kg}$ body weight, respectively), the flexor digitorum longus tendon (25 $\mathrm{mm}$ in length and $1 \mathrm{~mm}$ in diameter) was harvested by longitudinal medial incision of the right heel and the muscle tissue was removed from the graft. The knee joint capsule was opened, native ACL was excised and the successful transection confirmed by a positive Lachman test. Tibia and femoral tunnels of $1.1 \mathrm{~mm}$ diameter, $9 \mathrm{~mm}$, and $6 \mathrm{~mm}$ in length were created from the footprints of the native ACL to the medial side of the tibia and the lateral femoral condyle. The tendon graft was inserted through both bone tunnels and the graft was fixed to the tibial periosteum first. Through a pulley system, a freely suspended weight was used to provide a constant tensioning force of $4 \mathrm{~N}$ to the graft during its fixation to the neighbouring femoral periosteum. Finally, the fascia and other soft tissues were closed in layers. All animals were given $0.03 \mathrm{mg} / \mathrm{kg}$ body weight buprenorphine hydrochloride as analgesics and were allowed free cage activity after operation.

\section{Post-operative intra-articular injection}

hMT and tendon tissue harvested from the same patient undergoing ACL reconstruction (hTC 7) were washed in PBS, minced into small pieces, and plated in non-tissue culture treated plates separately at approx. 2 g per plate (Supplementary Figure 1). Tissue samples were cultured in SRM for three days, after which CM was collected, strained through $100 \mu \mathrm{m}$ filters, aliquoted, and stored at $-80^{\circ} \mathrm{C}$ until use. SRM alone was collected and used as control. Five animals per condition were used. Intra-articular injection was performed on day 7, 14, 21, 28, and 35 post-operatively. The different CM were individually loaded into a $50 \mu \mathrm{l}$ syringe with a 26G removable needle (Hamilton Company, NV, USA). Under general anaesthesia with a mixture of isofluorane $/ \mathrm{O}_{2}$, with the knee flexed, the needle was inserted perpendicularly through the patellar tendon to access the joint space, and $50 \mu \mathrm{l}$ of treatment solution was slowly injected. A total of five weekly injections were given per animal during the experiment.

\section{Histological analysis}

At six weeks post-operation, the rats were euthanised with an overdose of pentobarbital. The harvested knee joints were fixed in $10 \%(\mathrm{v} / \mathrm{v})$ buffered formalin, decalcified in $9 \%$ formic acid for five weeks and embedded in paraffin. Five-micrometre-thick paraffin sections along the sagittal plane of the knee were collected in groups of 10-20 sections at $500 \mu \mathrm{m}$ intervals. From each animal, 2 or 3 sections from each group of sections were chosen for histological examination of femoral tunnels, intra-articular graft mid- 
substance, and tibial tunnels [16]. Sections from the epiphyseal region were chosen for comparison of graft healing inside tunnels. $H \& E$ stained sections were examined under bright field light (Leica Microsystems, Wetzlar, Germany).

\section{Statistical analysis}

Statistical analysis was performed using Graphpad Prism 6 software. Two-way ANOVA and a Tukey post hoc test or Unpaired Student's t-test were used to compare the different conditions. A $\mathrm{P} \leq 0.05$ indicates a statistically significant difference. Results are shown as the mean \pm standard deviation.

\section{RESULTS}

\section{Upregulation of tendon/ligament markers in hTC co-cultured with myoblasts}

Indirect co-culture of hTC with BM-hMSCs, myoblasts, osteoblasts, and chondrocytes resulted in differential expression of lineage specific markers compared with the untreated control. Although co-culture of hTC with BM-hMSC and osteoblasts did not change the expression of T/L genes - neither genes related with chondrogenesis and osteogenesis - it was interesting to observe the effect of co-culturing hTC with myoblasts and chondrocytes. Co-culturing hTC with chondrocytes significantly increased the expression of chondrogenic (28.6 \pm 28.5 and $3.7 \pm 3$.6-fold increase vs. control for cartilage oligomeric matrix protein (COMP) and aggrecan (ACAN), respectively) and osteogenic marker (12.6 \pm 18.77-fold increase vs. control for ALP). It is notable that co-culturing hTC with myoblasts led to a statistically significant increase in the expression of SCX (5.5 \pm 4 .4-fold vs. control) - the master transcription factor involved in T/L specification. Moreover, tenomodulin (TNMD) - a well-recognised T/L lineage marker - was also upregulated solely on hTC exposed to myoblasts $(8.1 \pm 1.7$ fold) (Figure 2 and Supplementary Figure 2). Furthermore, T/L-related genes such collagen IA1 (COL1A1) (2.8 \pm 2 -fold), tenascin (TNC) $(2.4 \pm 1.6$-fold), and COMP (8.6 \pm 6-fold) were also upregulated in hTC exposed to myoblasts but did not achieve a statistically significant difference.

\section{Co-culture of hTC with chondrocytes does not increase the expression of $T / L$ markers}

Based on the abovementioned results, we decided to validate our findings on humanderived cells. To that end, we exposed primary isolated human hTC to primary isolated human chondrocytes and investigated the expression of a set of T/L- and cartilagerelated genes. With the exception of TNMD, which was down-regulated, co-culturing human primary hTC with human primary chondrocytes did not change the expression of T/L markers compared with the control (Supplementary Figure 3). Based on these findings, we decided to focus on the role of myoblasts on hTC. 
$T / L$ markers

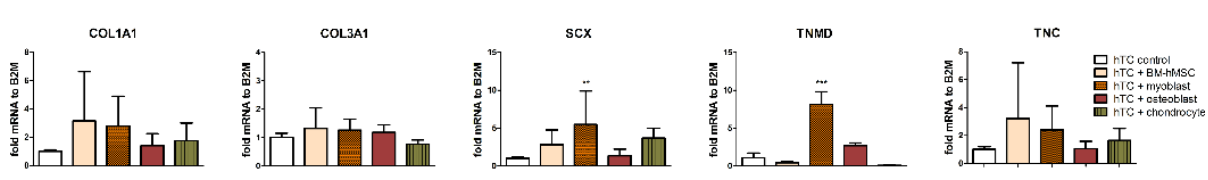

Chondrogenic and osteogenic lineage markers

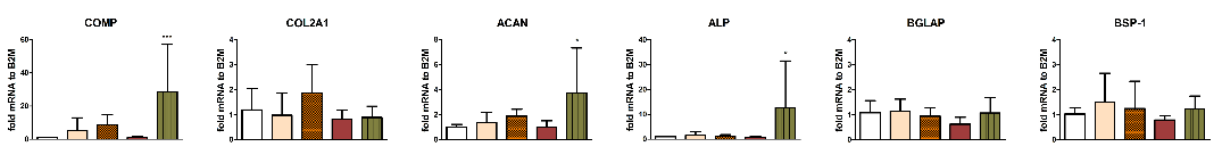

Figure 2. Gene expression of tendon-/cartilage- and bone-related markers in hTC when cultured in the presence of BM-hMSC, myoblasts (C2C12), osteoblasts (MC3T3), or chondrocytes (ATDC5) for seven days in 1\% FBS media. The graphs represent the average in gene expression over 3 TC donors. Statistically significant differences were found with $* * * p<0.001$, ** $p<0.01$ and $* p<0.05$.

\section{Genome-wide analysis of gene expression in $h T C$ exposed to myoblasts}

Based on the abovementioned results highlighting the positive role of co-culturing hTC with myoblasts, and in order to unravel the molecular players governing this interaction, we performed a genome-wide gene expression analysis to identify which genes were differentially regulated on hTC (from two different donors) exposed to myoblasts compared with the control. Transcriptional profiling revealed a total of 60 genes upregulated and 90 genes down-regulated in hTC cultured in the presence of myoblasts vs. control (Figure 3A). The top 20 up- and down-regulated genes and respective fold change are presented in Figure 3B; while the complete list comprising gene name, fold change, and location of gene function and gene function can be found in Supplementary Table 2. A brief analysis of the top 20 genes reveals an enrichment in genes involved in ECM modulation, such as COMP; tissue inhibitor of metalloproteinases 3 (TIMP3); Collagen type XI alpha 1 (COL11A1); retinoic acid receptor responder 2 (RARRES2); polypeptide N-acetylgalactosaminyltransferase 1 (GALNT1); stimulator of chondrogenesis 1 (SCRG1); fibronectin type III domain containing 1 (FNDC1); chitinase 3 like 1 (CHI3L1); C-X-C motif chemokine ligand 12 (CXCL12); platelet derived growth factor receptors like (PDGFRL) and complement C1r subcomponent (C1R) (Figure 3B, pattern-containing bars). Additionally, using the identified up- and down-regulated genes $(60+90)$ and GO enrichment analysis, we found significantly enriched GO categories in biological adhesion (GO:0022610, fold enrichment 2.9, P value $=0.05$ ); response to wounding (GO: 0009611, fold enrichment 3.6, $\mathrm{P}$ value $=$ 0.03); proteinaceous extracellular matrix (GO: 0005578, fold enrichment 4.4, $\mathrm{P}$ value = 0.004); extracellular region part (GO: 0044421, fold enrichment 2.7, $\mathrm{P}$ value $=0.003$ ); extracellular matrix (GO: 0031012, fold enrichment 4.8, $\mathrm{P}=$ value 0.0006); and extracellular region (GO: 0005576, fold enrichment 2.4, $\mathrm{P}$ value $=0.000008$ ) (Figure 3C). This analysis clearly demonstrates the influence myoblasts exert on the modulation of ECM molecules in hTC. Additionally, we found that within these ECM modulators, 
several genes were involved in the formation and remodelling of cartilage ECM, such as COMP, COL 11A1, TIMP3, SCRG1, or CHI3L1 (Figure 3D, orange circles). Furthermore, GO enrichment analysis revealed that, although not significant, a large number of genes were involved in the regulation of cell migration, motion, and locomotion, such as laminin subunit alpha 4 (LAMA4); podoplanin (PDPN); ectonucleotide pyrophosphatase/phosphodiesterase 2 (ENPP2); platelet derived growth factor receptor alpha (PDGFRA); thrombospondin 1 (THBS1); adenosine A1 receptor (ADORA1); tropomyosin 1 (TPM1); CXCL12; LIM zinc finger domain containing 2 (LIMS2); annexin A2 (ANXA2); tensin 3 (TNS3); RARRES2; actin; and alpha 2 smooth muscle aorta (ACTA2) (Figure 3D, dark green circles). Finally, we analysed the location of the identified gene functions and found that the majority of the gene functions were located within the cytoplasma (34\%), followed by plasma membrane (23\%), extracellular space (18\%), and nucleus (10\%) (Figure 3E). Gene function analysis showed an enrichment in genes involved in enzyme (17\%), while a small percentage of genes was involved in kinase, transmembrane receptor, peptidase, and transcription regulator (each 5\%), or phosphatase (3\%) and cytokine and G-protein coupled receptor (2\%). The remaining genes showed enrichment in other classes of genes (52\%) (Figure 3F).

\section{Analysis of the secretome of myoblast co-cultured with hTC}

To identify which factors secreted by myoblasts may be responsible for the effects observed on hTC, we performed a protein array study in which we analysed a panel of cytokines and growth factors released in the culture media during indirect co-culture of myoblasts with hTC. Our results showed that, compared with the control (hTC alone), co-culture with myoblasts upregulated the expression of monocyte chemioattractant protein-1(MCP-1) 7.4-fold, vascular endothelial growth factor (VEGF) 1.4-fold, interleukin 6 (IL-6) 1.8-fold, and Rantes 1.7-fold (Figure 4).

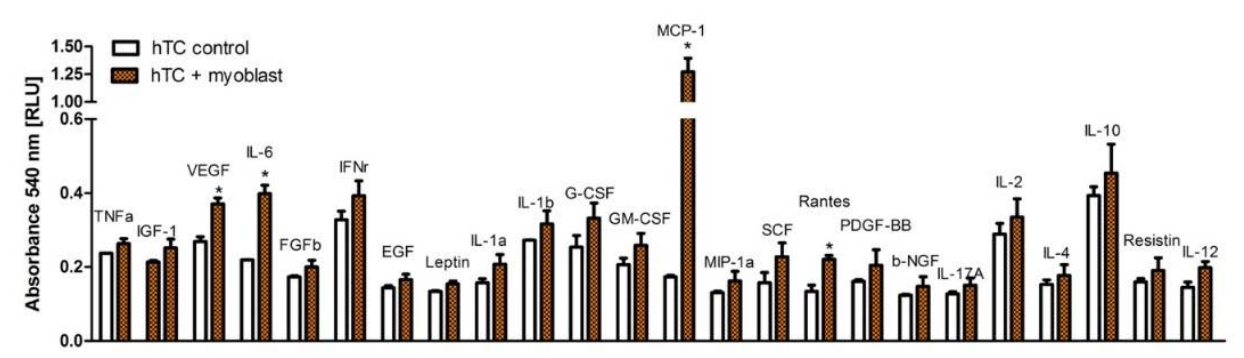

Figure 4. Protein array study showing cytokines and growth factors produced by mouse myoblast cell line when co-cultured with hTC1 and hTC2. The values are shown as the average over the two hTC donors and represented as a relative light unit. Mouse myoblasts have been shown to produce VEGF, IL-6, MCP-1, and Rantes. Statistically significant differences were found with *p $<0.05$ 

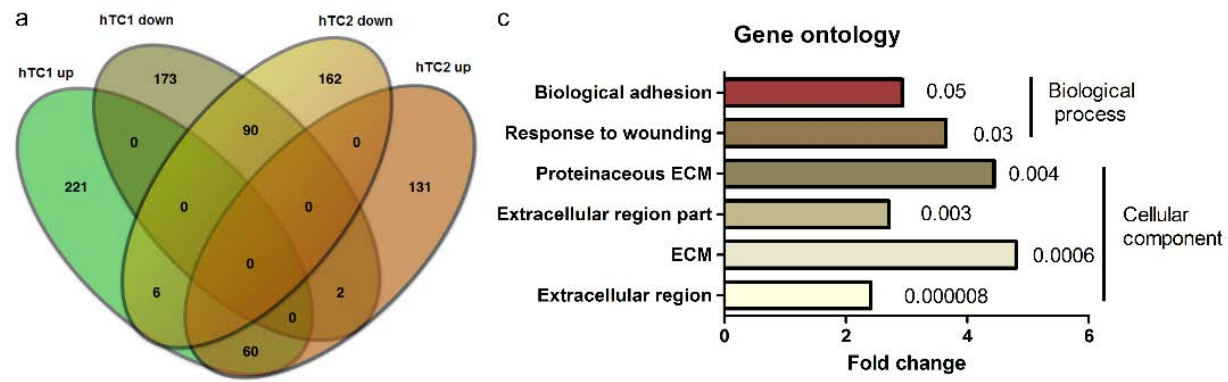

b

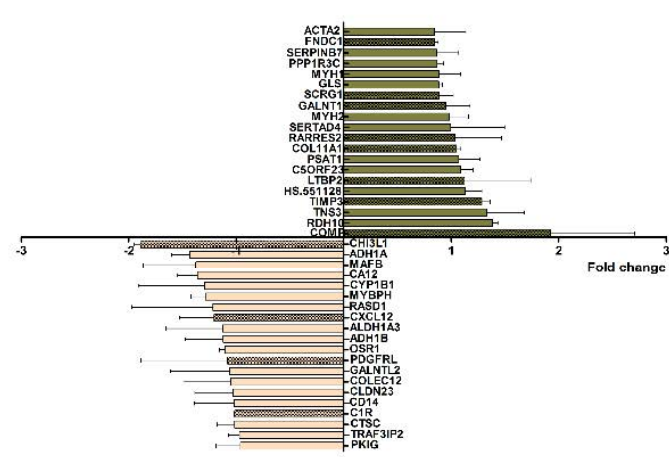

e
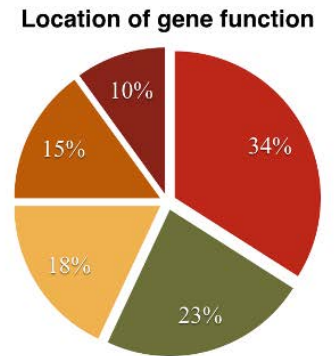

Cytoplasm Plasma Membrane Extracellular space Other
Nucleus

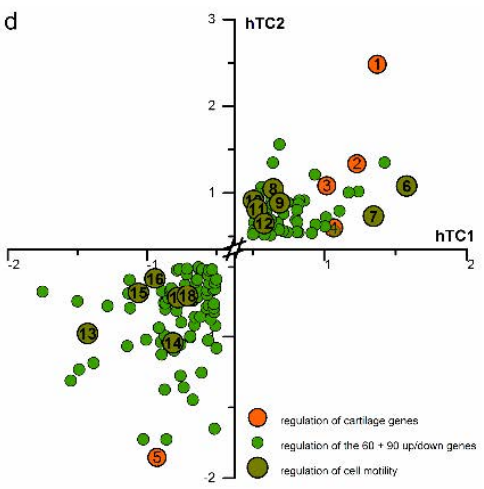

f

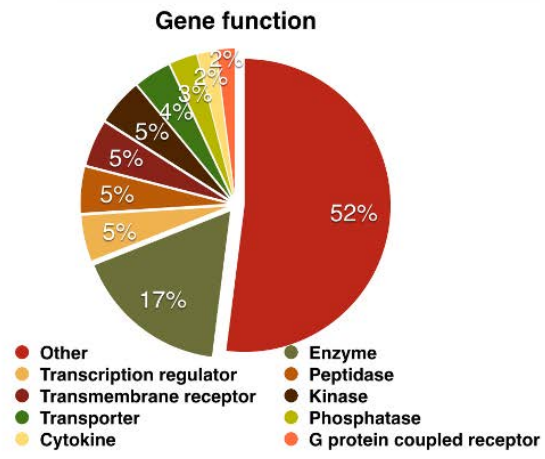

Figure 3. Genome-wide microarray and GO analysis of differentially expressed probe sets. (A) Venn diagram of differentially expressed genes. The number of significant up- and down-regulated genes in hTC1 and hTC2 and their intersection, indicating the number of common and individually regulated genes. Differentially expressed genes were identified by pairwise comparison analysis of hTC + myoblasts and hTC alone. (B) Map of the top 20 upand down-regulated genes. Pattern graphs represent genes involved in ECM remodelling. (C) GO analysis of all common differentially expressed genes and the identified significant enriched biological process and cellular component GO clusters. (D) hTC1 hTC2 plot of fold change of the differentially expressed genes. Positive fold change defines positive expression of genes in hTC indirect co-cultured with myoblasts and reverse for negative fold change. Orange circles represent genes that regulate cartilage ((1) COMP, (2) TIMP3, (3) COL11A1, (4) CHRDL2, (5) CHI3L1), dark green circles represent genes that regulate cell motility ((6) TNS3, (7) RARRES2, (8) ACTA2, (9) ANXA2, (10) TPM1 (11), LIMS2, (12) THBS1, (13) CXCL12, (14) ENPP2, (15) ADORA1, (16) LAMA4, (17) PDPN, (18) PDGFRA), while small green circles represent the rest of the $60+90$ commonly expressed genes. (E) Pie diagram representing the location of gene function. (E) Pie diagram representing gene function. 


\section{hTC exposed to $h M T C M$ upregulated T/L genes}

To translate our findings into a potential therapy for T/L healing we decided to analyse whether hTC responded similarly when exposed to soluble factors obtained from hMT. To do so, we exposed hTC to hMT CM from three different donors for seven days. In line with the results obtained for myoblasts, our results showed a statistically significant upregulation for TNMD (40 \pm 40-fold), TNC (1.5 \pm 0.3 -fold), and COMP ( $2 \pm 0.7$-fold) between hMT CM treated cells vs. control (Figure 5 and Supplementary Figure 4).
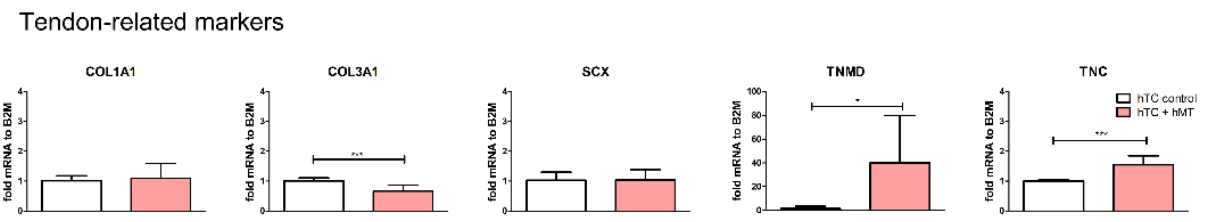

Differentiation related markers
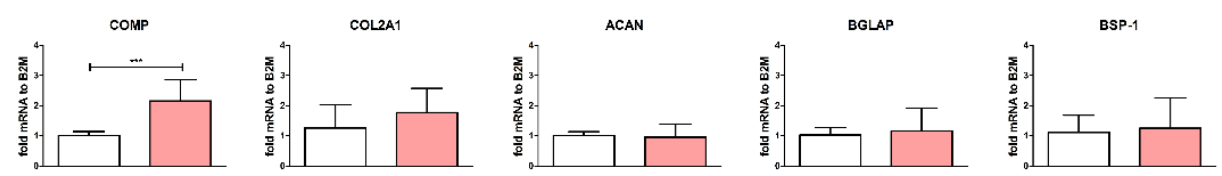

Figure 5. Gene expression of tendon, cartilage, and osteogenic related markers in hTCs when cultured in the presence or absence of muscle conditioned media. The graphs represent the average in gene expression over three hTC donors. Statistically significant differences were found with ***p $<0.001$.

\section{Myoblast indirect co-culture and hMT CM enhance collagen production}

Given the effects observed in the expression of ECM-related genes upon indirect coculture of hTC with myoblasts and hMT CM, we proceeded to quantify the amount of collagen produced by hTC exposed to the respective condition for 29 days. We found that, compared with the control, hTC exposed to myoblasts significantly increased the production of collagen (1.7-fold for hTC1 and 2.2-fold for hTC2 (Figure 6 A-B, D-E, G-H)), while the addition of hMT CM resulted in a 3.3-fold increase for hTC6 (Figure 6 $\mathrm{C}, \mathrm{F}, \mathrm{I})$. Based on these results, we decided to test the effect of hMT CM in a rat model of ACL reconstruction.

\section{Treatment of hMT CM improved healing after ACL reconstruction}

A rat ACL reconstruction model was used to test the effects of hMT CM. Tendon tissue $\mathrm{CM}$ was used as a control for the in vivo study. At six weeks post-operation, healing responses were evident in all ACL reconstructed rat knees, with respect to bone tunnel healing, bone-to-graft incorporation, and tendon-graft remodelling (Figure 7). The presence of Sharpey's fibre and/or fibrocartilage interface (Figure 1D-I) was observed 


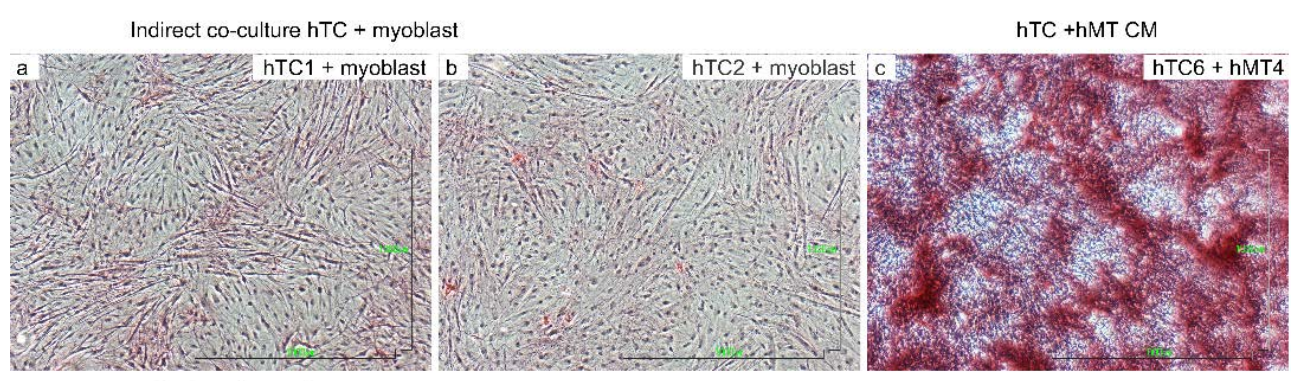

hTC alone (control)
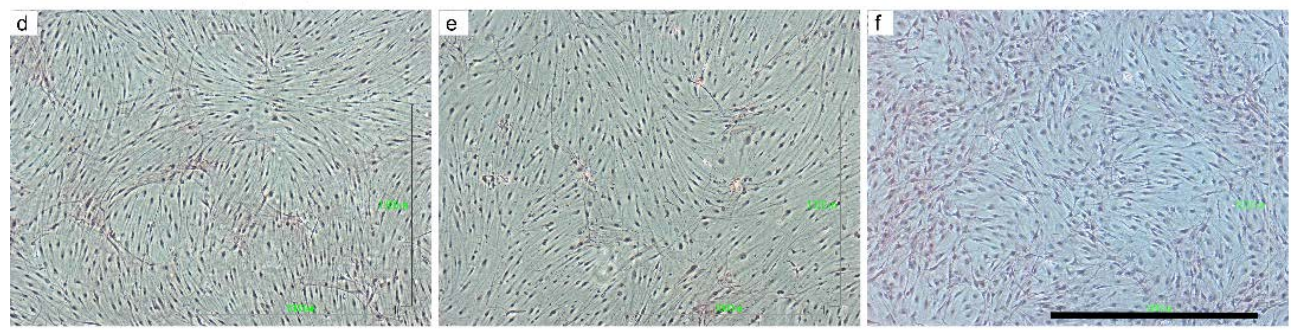

Collagen content quantification
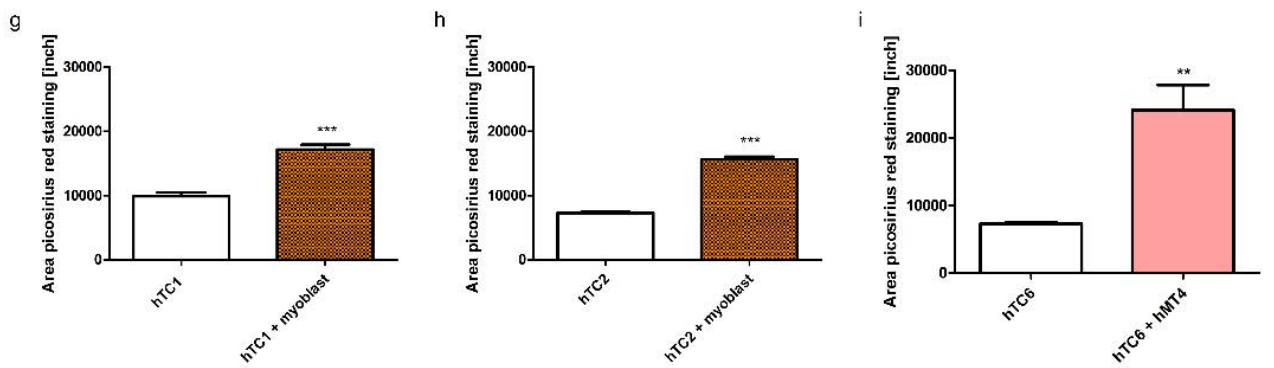

Figure 6. Picrosirius red staining of hTCs indirect co-cultured with myoblasts or exposed to muscle tissue CM. (A) hTC1 indirect co-cultured with myoblasts. (B) hTC2 indirect cocultured with myoblasts. (C) hTC6 exposed to muscle tissue CM. (D, E, F) hTC1/hTC2/hTC6 cultured alone (negative control). ( $G, H, I)$ Quantification of Picrosirius red staining using FIJI software. Statistically significant differences were found with ***p < 0.001 and ${ }^{* * p}<0.01$. Scale bar represents $1 \mathrm{~mm}$.

at the graft incorporation to surrounding bone in both femoral and tibial tunnels and in all groups. Additionally, the cellularity in the tendon graft at the intra-articular portion was high in all groups; whereas the degree of cell infiltration in bone tunnels varied between different groups (Figure $7 \mathrm{~J}-\mathrm{L}$ ). Bone tunnel closure did not show any significant differences in tibial bone tunnel closure between groups; however, significant femoral bone tunnel closure was observed in hMT CM group (four out of five samples) (Figure 7C and F) as compared with the basic media group (one out of five samples) (Figure 7A and D) and tendon CM group (one out of five samples) (Figure 7B and E). 


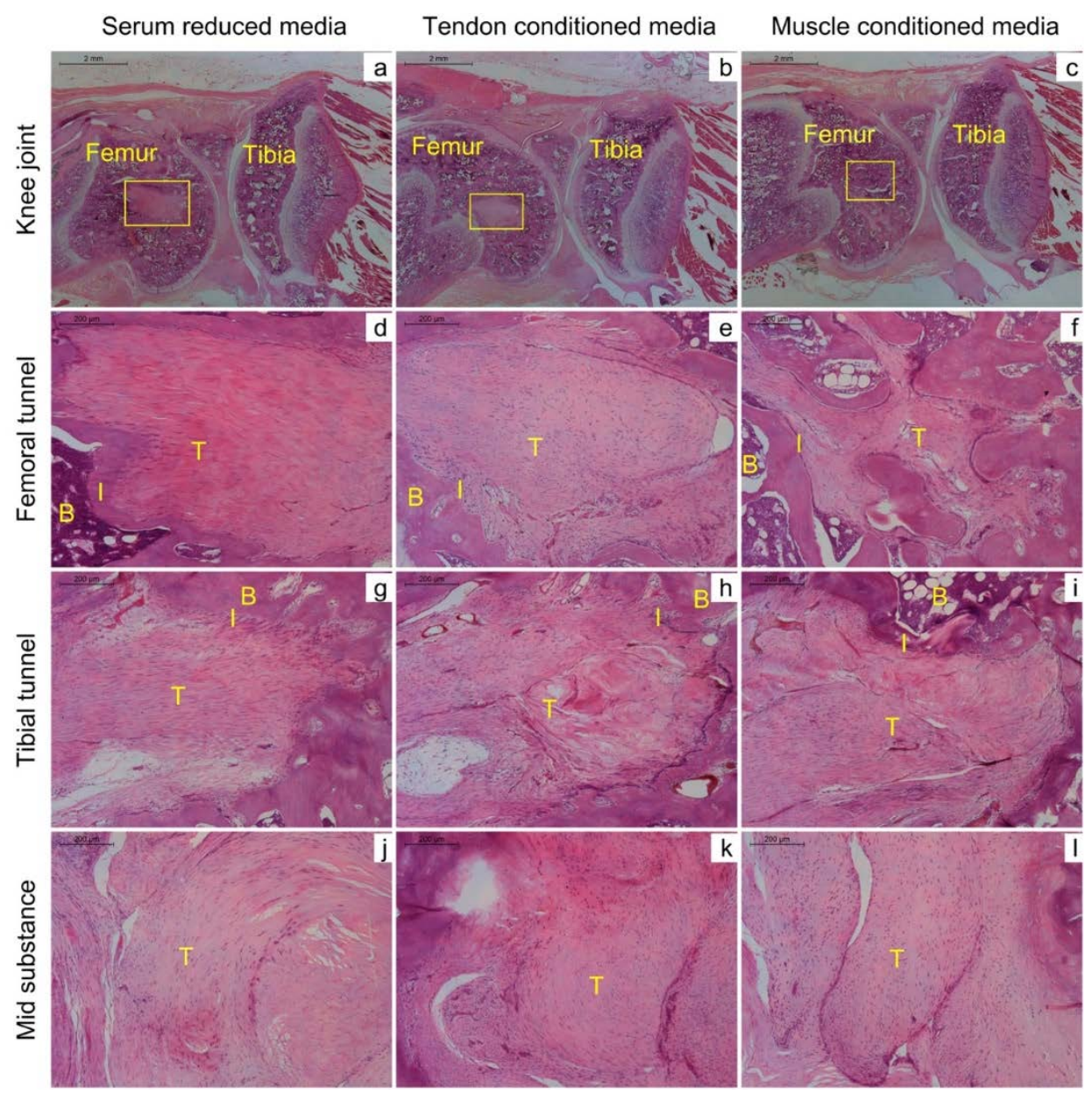

Figure 7 Histological images showing sagittal views of ACL reconstructed rat knees at six weeks post-operation, treated with either basic media, tendon conditioned media, or muscle conditioned media. D-F are magnified images of the tendon graft, marked in squares of $A-C$ respectively. Significant bone tunnel closure is observed in the femoral tunnels of muscle conditioned media group $(C, F)$, but not in the other two groups. Sharpey's fibre and fibrocartilage zone is present at bone-to-tunnel interface in all groups, as indicated by ' $I$ ' in $D-I$. (H\&E staining. Optical magnification: $12.5 x$ in $A-C, 100 x$ in $D$ $L) . B=$ bone, $I=$ Bone-tendon interface, $T$ = tendon graft.

\section{Discussion}

Intra-articular healing and remodelling of tendon grafts, following an ACL reconstruction, has been described in the literature as a complex and long-term process, which delays the time for patients to return to work and sport activities $[17,18]$. To accelerate the healing process and the integration of the tendon graft into the new environmental conditions, we approached the remodelling process by engaging the use 
of cellular crosstalk known to trigger signalling cascades beneficial in tissue remodelling. Inspired by the embryonic development of $\mathrm{T} / \mathrm{L}$, where tendon cells experience behavioural changes as result of interaction with surrounding tissue cells, we explored, in a simplified 2D in vitro model, the effects of surrounding mature tissue cells, such as myoblasts, chondrocytes, osteoblasts, or BM-hMSC on the expression of a panel of ECM, and differentiation genes in tendon cells. We found that myoblasts and chondrocytes modulated tendon cellular responses, resulting in an increased expression of tendon and cartilage related markers. The expression of SCX in hTC exposed to myoblasts accompanied the expression of TNMD and a trend towards increased expression in COLIA1, TNC, and COMP. This regulatory effect exerted by skeletal muscle cells on tendon cells by exchange of paracrine factors has been previously reported to occur during tendon development where the expression of SCX and TNMD were described to be dependent on muscle signals $[19,20]$. To better understand the role that myoblasts play in modulating tendon cell commitment, we performed a genomewide analysis on tendon cells, using the same experimental and donor setting. We found that a large majority of differentially expressed genes were involved in ECM modulation. Since it is known that ECM remodelling plays a key role in restoring the biology and function of T/L during the healing process, and since myoblasts play a key role in tissue contraction and organ fibrosis during wound healing [21, 22], our findings suggest that in a simplified 2D environment, with no tensile forces, the chemokines released by myoblasts were enough to affect matrix synthesis and turnover. Further analysis identified that some of the differentially expressed ECM genes - COMP, COL11A1, TIMP3, SCRG1, CHI3L1, CHRDL2 - are known to be involved in cartilage matrix remodelling [23-28], suggesting an important role in guiding tendon-bone interface regeneration. Other regulated genes were found to be involved in cell migration and motion, such as TNS3, RARRES2, ACTA2, ANXA2, TPM1, LIMS2, THBS1, CXCL12, ENPP2, ADORA1, LAMA4, PDPN, and PDGFRA [29-41], suggesting an important role for cell migration on the repopulation of the tendon graft, while influencing revascularisation and tendon-bone closure. To elucidate the molecular signals exchanged between myoblasts and hTC, we analysed a panel of cytokines and identified MCP-1, VEGF, Rantes, and IL-6 as being secreted by myoblasts during indirect co-culture with both hTC donors. We propose two explanations that relate the expression of the identified cytokines to the regulation of genes. One explanation is the fact that MCP-1, VEGF, and Rantes are known chemotactic cytokines [42-44], which may explain the regulation of a large number of genes involved in cell migration and motion. Secondly, Rantes and IL-6 are also known as inflammatory cytokines, which may explain the regulation of genes involved in GO category response to wounding.

In our attempt to change to a more clinically relevant approach, we examined the influence hMT may have on hTC. Consequently, the remnant hMT removed during preparation of the tendon graft and harvest from a patient undergoing ACL reconstruction [45] offered us the chance to investigate its role in tendon cell commitment and its potential beneficial use in accelerating tendon graft remodelling. We found that CM collected from hMT induces, similarly to myoblasts co-culture, an 
increase in expression of $\mathrm{T} / \mathrm{L}$ and cartilage related markers, which in turn are involved in synthesis and turnover of the ECM. These findings in gene expression were further confirmed by increased collagen production in hTC exposed to myoblasts or hMT CM. While Murray and Spector have identified the presence of myofibroblasts in the ruptured human ACL and hypothesised that the contractile role of myofibroblasts in the ACL could be responsible for the wrinkling of the ECM and the formation of crimp [46], Lei Sun et al. have shown in a rabbit model that hMT left on tendon graft promotes the intra-articular healing and remodelling of the graft [47]. Here we speculate that collection and later stage delivery of hMT CM, at the end of the inflammatory stage, would influence tendon remodelling by increasing the number of cells, blood vessels, and remodelling of the ECM for a better ligamentisation. We used an ACL reconstruction rat model and injected hMT CM, tendon tissue CM, or SRM control into the operated joints of the animals. We showed that femoral tunnel closure was promoted by hMT CM, but tibial tunnel closure was not affected. This difference might be attributed to the different mechanical environments inside femoral and tibial tunnels owing to the relative positions of graft and the tunnels. Moreover, the distribution of bioactive factors in the knee joints upon injection of hMT CM may also affect treatment outcomes. A controlled delivery system will be necessary to direct the bioactive factor to the healing site along the tendon graft.

Overall, we showed that myoblast-derived molecules influence hTC commitment and ECM remodelling and are capable of accelerating intra-articular healing in an ACL reconstruction rat model. Consequently, these findings provide preliminary proof that remnant hMT may become a useful tool in accelerating ACL reconstruction healing.

\section{AbBreviations}

anterior cruciate ligament (ACL); tendon and ligament (T/L); human hamstring tendon-derived cells (hTC); extracellular matrix (ECM); human muscle tissue (hMT); condition media (CM); basic media (BM); Lascorbic acid 2-phosphate magnesium salt (ASAP); fetal bovine serum (FBS); serum reduced media (SRM); beta-2-microglobulin (B2M); scleraxis (SCX); Gene Ontology (GO); bone marrow-derived human mesenchymal stromal cells (BM-hMSC); cartilage oligomeric matrix protein (COMP); aggrecan (ACAN); tenomodulin (TNMD); Collagen IA1 (COL1A1); tenascin (TNC); tissue inhibitor of metalloproteinases 3 (TIMP3); Collagen type XI alpha 1 (COL11A1); retinoic acid receptor responder 2 (RARRES2); polypeptide $\mathrm{N}$-acetylgalactosaminyltransferase 1 (GALNT1); stimulator of chondrogenesis 1 (SCRG1); fibronectin type III domain containing 1 (FNDC1); chitinase 3 like 1 (CHI3L1); C-X-C motif chemokine ligand 12 (CXCL12); platelet derived growth factor receptors like (PDGFRL) and complement C1r subcomponent (C1R); laminin subunit alpha 4 (LAMA4); podoplanin (PDPN); ectonucleotide pyrophosphatase/phosphodiesterase 2 (ENPP2); platelet derived growth factor receptor alpha (PDGFRA); thrombospondin 1 (THBS1); adenosine A1 receptor (ADORA1); tropomyosin 1 (TPM1); LIM zinc finger domain containing 2 (LIMS2); annexin A2 (ANXA2); tensin 3 (TNS3); alpha 2 smooth muscle aorta (ACTA2); monocyte chemioattractant protein-1(MCP-1); vascular endothelial growth factor (VEGF); interleukin 6 (IL-6). 


\section{SUPPLEMENTARY FIGURES}

\section{Please note: cluster of figures (1 and 3)}

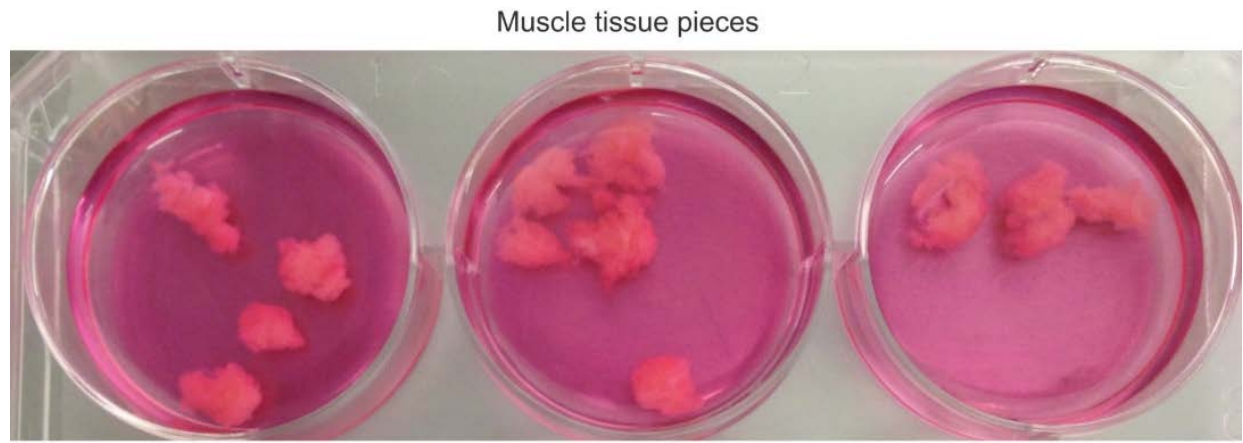

\section{Tendon tissue pieces}

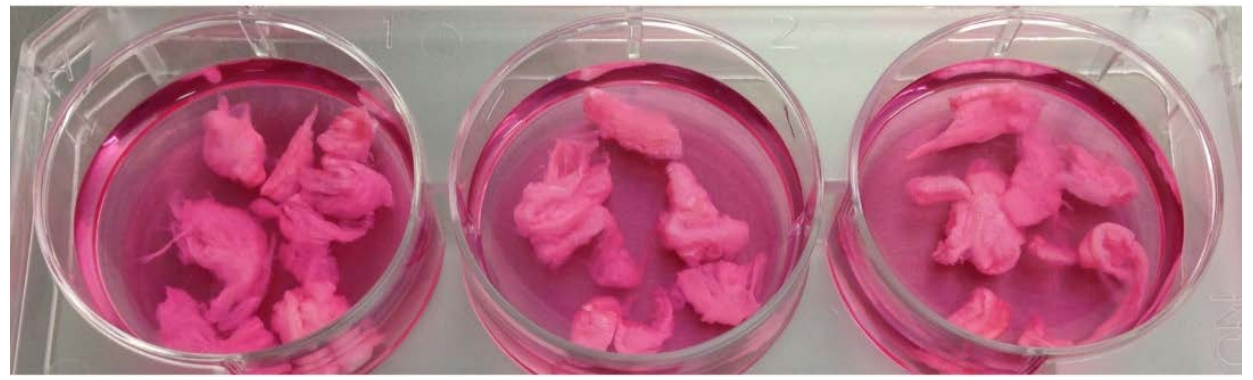

Supplementary Figure 1. Collection of CM from (A) muscle tissue and (B) tendon tissue. Tissue was plated at $2 \mathrm{~g}$ per 6-well plates.
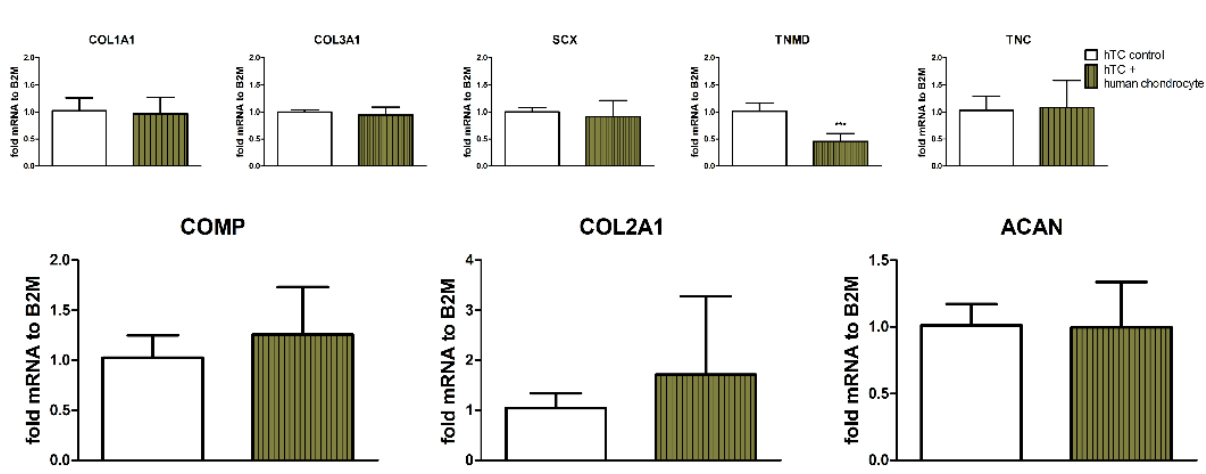

Supplementary Figure 3. Donor dependent gene expression of tendon and cartilage related markers in hTC indirectly co-cultured with chondrocytes. Statistically significant differences were found with ${ }^{* *} p<0.01$ and ${ }^{*} p<0.05$. 
hTC1 gene expression
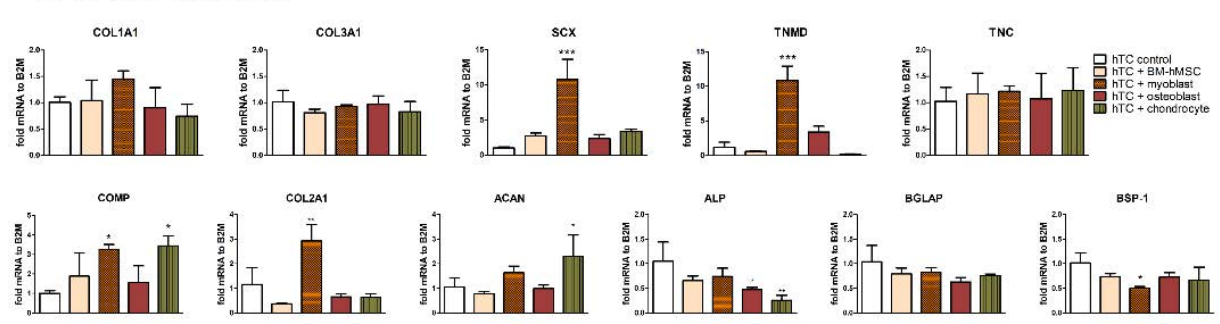

hTC2 gene expression
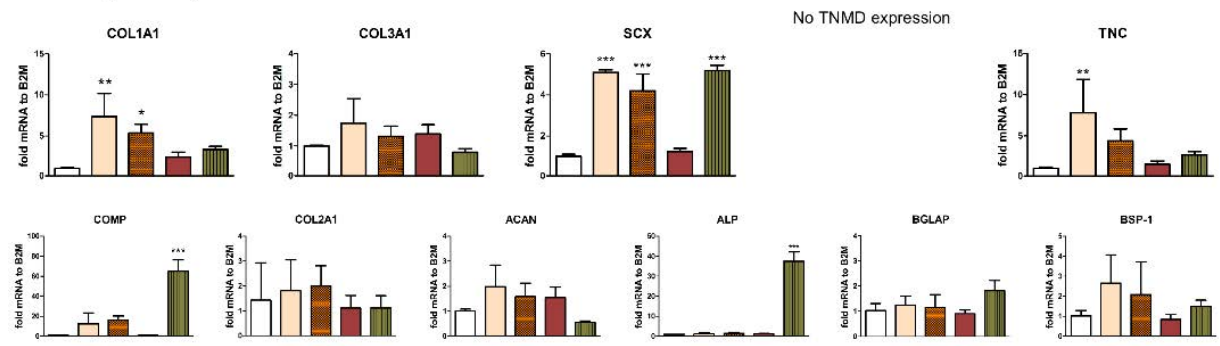

hTC3 gene expression

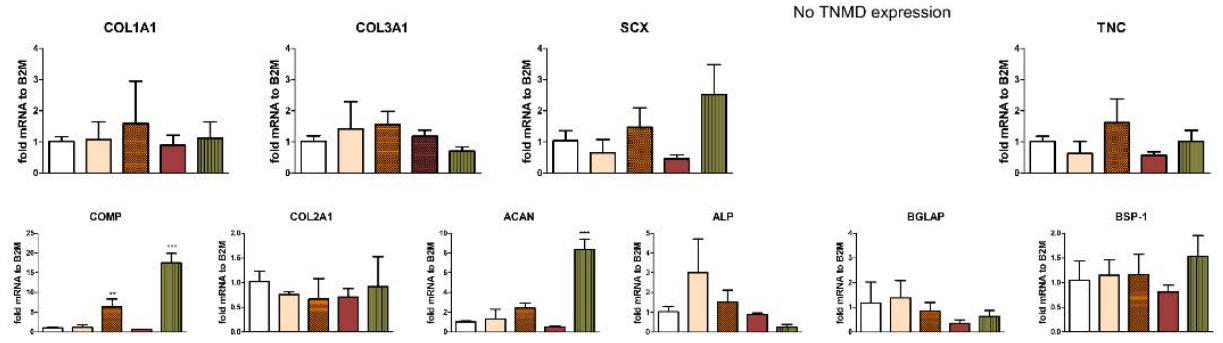

Supplementary Figure 2. Donor dependent gene expression of tendon/cartilage and bonerelated markers in hTC indirectly co-cultured with BM-hMSC, myoblasts, osteoblasts, or chondrocytes. Statistically significant differences were found with ${ }^{* * *} p<0.001,{ }^{* *} p<0.01$ and ${ }^{*} p<0.05$. 
Gene expression in hTC5 + hMT1
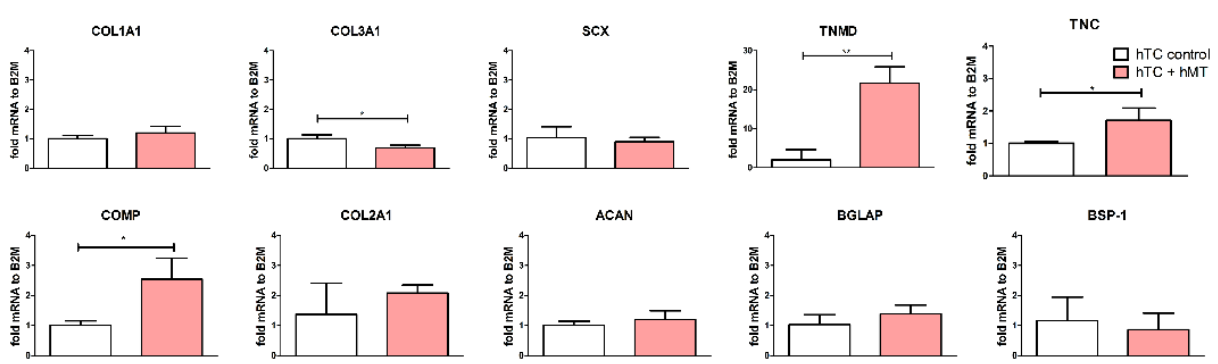

Gene expression in hTC5 + hMT2
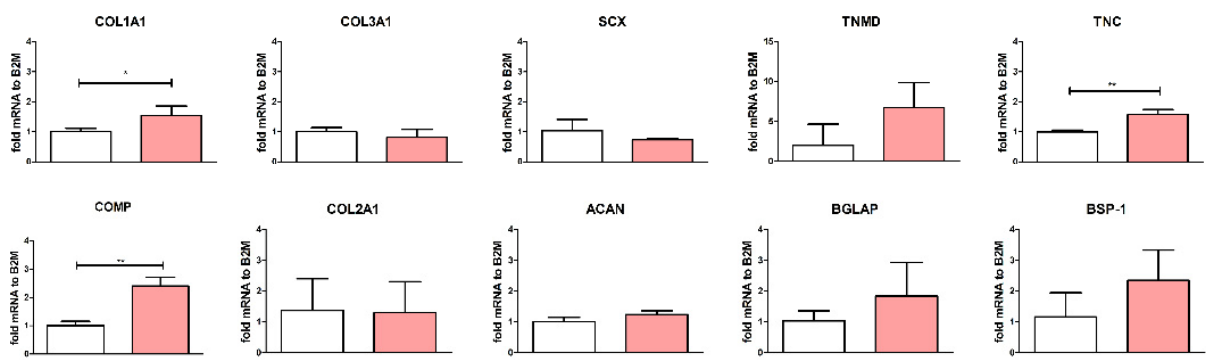

Gene expression in hTC6 + hMT3
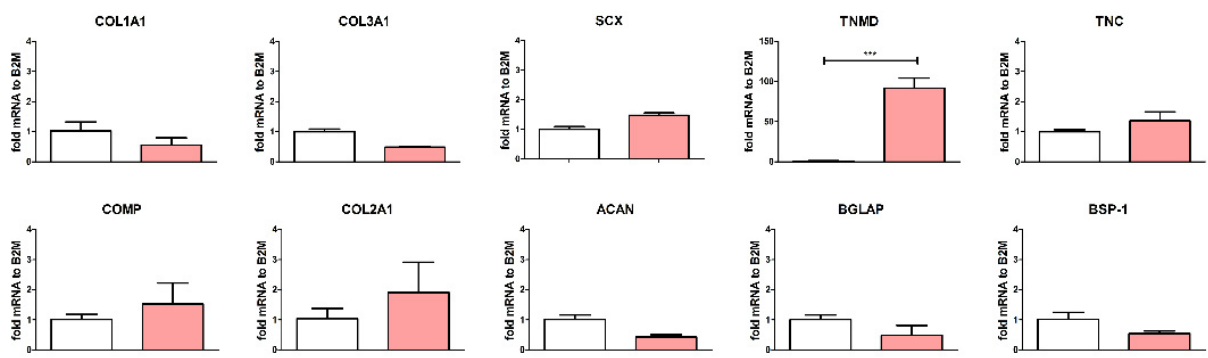

Supplementary Figure 4. Gene expression of tendon, cartilage, and osteogenic related markers in hTC cultured in the presence or absence of hMT CM. Statistically significant differences were found with $* * * p<0.001$. 


\section{SUPPLEMENTARY TABLES}

\begin{tabular}{|c|c|c|}
\hline Gene & Symbol & Primer Sequence \\
\hline 及2-microglobulin & B2M & $\begin{array}{l}\text { 5'-ACAAAGTCACATGGTTCACA } \\
\text { 5'-GACTTGTCTTTCAGCAAGGA }\end{array}$ \\
\hline collagen type I alpha 1 & COL1A1 & $\begin{array}{l}\text { 5'-GTCACCCACCGACCAAGAAACC } \\
\text { 5'-AAGTCCAGGCTGTCCAGGGATG }\end{array}$ \\
\hline collagen type III alpha 1 & COL3A1 & $\begin{array}{l}\text { 5'-GCCAACGTCCACACCAAATT } \\
\text { 5'-AACACGCAAGGCTGTGAGACT }\end{array}$ \\
\hline $\begin{array}{l}\text { cartilage oligomeric } \\
\text { matrix protein }\end{array}$ & COMP & $\begin{array}{l}\text { 5'-GTCCGCTGTATCAACACCAG } \\
\text { 5'-GGAGTTGGGGACGCAGTTA }\end{array}$ \\
\hline tenascin C & TNC & $\begin{array}{l}\text { 5'-TGGGCAGATTTCACGGCTG } \\
\text { 5'-TGCTCTGAGCCCGAATGTC }\end{array}$ \\
\hline tenomodulin & TNMD & $\begin{array}{l}\text { 5'-TGTATTGGATCAATCCCACTCTAAT } \\
\text { 5'-TTTTTCGTTGGCAGGAAAGT }\end{array}$ \\
\hline collagen type II alpha 1 & COL2A1 & $\begin{array}{l}\text { 5'-CCAGATGACCTTCCTACGCC } \\
\text { 5'-TTCAGGGCAGTGTACGTGAAC }\end{array}$ \\
\hline aggrecan & ACAN & $\begin{array}{l}\text { 5'-GGCCTCTCCAGTCTCATTCTC } \\
\text { 5'-AGGCAGCGTGATCCTTACC }\end{array}$ \\
\hline bone sialoprotein I & BSP-I & $\begin{array}{l}\text { 5'-CCСCACСTTTTGGGAAAACCA } \\
\text { 5'-TCCCCGTTCTCACTTTCATAGAT }\end{array}$ \\
\hline $\begin{array}{l}\text { Bone gamma- } \\
\text { carboxyglutamic acid- } \\
\text { containing protein }\end{array}$ & BGLAP & $\begin{array}{l}\text { 5'-GGCAGCGAGGTAGTGAAGAG } \\
\text { 5'-GATGTGGTCAGCCAACTCGT }\end{array}$ \\
\hline Alkaline phosphatase & ALP & $\begin{array}{l}\text { 5'-ACAAGCACTCCCACTTCATC } \\
\text { 5'-TTCAGCTCGTACTGCATGTC }\end{array}$ \\
\hline
\end{tabular}

Supplementary Table 1. Primers used for qRT-PCR analysis 


\begin{tabular}{|c|c|c|c|c|}
\hline Gene symbol & Gene description & $\begin{array}{l}\log F \\
C *\end{array}$ & Location & Function \\
\hline COMP & $\begin{array}{l}\text { Homo sapiens cartilage } \\
\text { oligomeric matrix protein }\end{array}$ & 1.93 & $\begin{array}{l}\text { Extracellul } \\
\text { ar space }\end{array}$ & other \\
\hline RDH10 & $\begin{array}{l}\text { Homo sapiens retinol } \\
\text { dehydrogenase } 10 \text { (all-trans) }\end{array}$ & 1.39 & Nucleus & enzyme \\
\hline TNS3 & Homo sapiens tensin 3 & 1.33 & $\begin{array}{l}\text { Plasma } \\
\text { Membrane }\end{array}$ & phosphatase \\
\hline TIMP3 & $\begin{array}{l}\text { Homo sapiens TIMP } \\
\text { metallopeptidase inhibitor } 3\end{array}$ & 1.28 & $\begin{array}{l}\text { Extracellul } \\
\text { ar Space }\end{array}$ & other \\
\hline HS.551128 & Homo sapiens MSTP131 & 1.13 & & \\
\hline LTBP2 & $\begin{array}{l}\text { Homo sapiens latent } \\
\text { transforming growth factor } \\
\text { beta binding protein } 2\end{array}$ & 1.12 & $\begin{array}{l}\text { Extracellul } \\
\text { ar Space }\end{array}$ & other \\
\hline C5ORF23 & $\begin{array}{l}\text { Homo sapiens chromosome } 5 \\
\text { open reading frame } 23\end{array}$ & 1.09 & - & - \\
\hline PSAT1 & $\begin{array}{l}\text { Homo sapiens phosphoserine } \\
\text { aminotransferase } 1\end{array}$ & 1.07 & Cytoplasm & enzyme \\
\hline COL11A1 & $\begin{array}{l}\text { Homo sapiens collagen, type } \\
\text { XI, alpha } 1 \text {, transcript variant } \\
\text { A }\end{array}$ & 1.05 & $\begin{array}{l}\text { Extracellul } \\
\text { ar Space }\end{array}$ & other \\
\hline RARRES2 & $\begin{array}{l}\text { Homo sapiens retinoic acid } \\
\text { receptor responder (tazarotene } \\
\text { induced) } 2\end{array}$ & 1.04 & $\begin{array}{l}\text { Plasma } \\
\text { Membrane }\end{array}$ & $\begin{array}{l}\text { transmembra } \\
\text { ne receptor }\end{array}$ \\
\hline SERTAD4 & $\begin{array}{l}\text { Homo sapiens SERTA domain } \\
\text { containing } 4\end{array}$ & 1 & Other & other \\
\hline MYH2 & $\begin{array}{l}\text { Homo sapiens myosin, heavy } \\
\text { chain } 2 \text {, skeletal muscle }\end{array}$ & 0.98 & Cytoplasm & enzyme \\
\hline GALNT1 & $\begin{array}{l}\text { Homo sapiens UDP-N-acetyl- } \\
\text { alpha-D- } \\
\text { galactosamine:polypeptide N- } \\
\text { acetylgalactosaminyltransferas } \\
\text { e } 1\end{array}$ & 0.95 & Cytoplasm & enzyme \\
\hline SCRG1 & $\begin{array}{l}\text { Homo sapiens scrapie } \\
\text { responsive protein } 1\end{array}$ & 0.89 & $\begin{array}{l}\text { Extracellul } \\
\text { ar Space }\end{array}$ & other \\
\hline GLS & Homo sapiens glutaminase & 0.89 & Cytoplasm & enzyme \\
\hline MYH1 & $\begin{array}{l}\text { Homo sapiens myosin, heavy } \\
\text { polypeptide } 1 \text {, skeletal muscle, } \\
\text { adult }\end{array}$ & 0.88 & $\begin{array}{l}\text { Plasma } \\
\text { Membrane }\end{array}$ & enzyme \\
\hline PPP1R3C & $\begin{array}{l}\text { Homo sapiens protein } \\
\text { phosphatase } 1 \text {, regulatory } \\
\text { (inhibitor) subunit 3C }\end{array}$ & 0.87 & Cytoplasm & phosphatase \\
\hline SERPINB7 & $\begin{array}{l}\text { Homo sapiens serpin peptidase } \\
\text { inhibitor, clade B (ovalbumin), } \\
\text { member } 7\end{array}$ & 0.87 & Cytoplasm & other \\
\hline FNDC1 & $\begin{array}{l}\text { Homo sapiens fibronectin type } \\
\text { III domain containing } 1\end{array}$ & 0.85 & $\begin{array}{l}\text { Plasma } \\
\text { Membrane }\end{array}$ & other \\
\hline
\end{tabular}




\begin{tabular}{|c|c|c|c|c|}
\hline ACTA2 & $\begin{array}{l}\text { Homo sapiens actin, alpha } 2 \text {, } \\
\text { smooth muscle, aorta }\end{array}$ & 0.84 & Cytoplasm & other \\
\hline CHRDL2 & Homo sapiens chordin-like 2 & 0.83 & Cytoplasm & other \\
\hline SCARF2 & $\begin{array}{l}\text { Homo sapiens scavenger } \\
\text { receptor class F, member } 2\end{array}$ & 0.83 & $\begin{array}{l}\text { Plasma } \\
\text { Membrane }\end{array}$ & $\begin{array}{l}\text { transmembra } \\
\text { ne receptor }\end{array}$ \\
\hline COL8A2 & $\begin{array}{l}\text { Homo sapiens collagen, type } \\
\text { VIII, alpha } 2\end{array}$ & 0.82 & $\begin{array}{l}\text { Extracellul } \\
\text { ar Space }\end{array}$ & other \\
\hline C1ORF133 & $\begin{array}{l}\text { Homo sapiens chromosome } 1 \\
\text { open reading frame } 133\end{array}$ & 0.82 & - & - \\
\hline BHLHB2 & $\begin{array}{l}\text { Homo sapiens basic helix- } \\
\text { loop-helix domain containing, } \\
\text { class B, } 2\end{array}$ & 0.82 & Nucleus & $\begin{array}{l}\text { transcription } \\
\text { regulator }\end{array}$ \\
\hline DDIT4 & $\begin{array}{l}\text { Homo sapiens DNA-damage- } \\
\text { inducible transcript } 4\end{array}$ & 0.81 & Cytoplasm & other \\
\hline TRIL & $\begin{array}{l}\text { Homo sapiens TLR4 interactor } \\
\text { with leucine rich repeats }\end{array}$ & 0.81 & Other & other \\
\hline VLDLR & $\begin{array}{l}\text { Homo sapiens very low density } \\
\text { lipoprotein receptor }\end{array}$ & 0.81 & $\begin{array}{l}\text { Plasma } \\
\text { Membrane }\end{array}$ & transporter \\
\hline HAPLN1 & $\begin{array}{l}\text { Homo sapiens hyaluronan and } \\
\text { proteoglycan link protein } 1\end{array}$ & 0.79 & $\begin{array}{l}\text { Extracellul } \\
\text { ar Space }\end{array}$ & other \\
\hline ANXA2 & $\begin{array}{l}\text { Homo sapiens annexin A2 } \\
\text { (ANXA2), transcript variant } 2\end{array}$ & 0.79 & $\begin{array}{l}\text { Plasma } \\
\text { Membrane }\end{array}$ & other \\
\hline MYLK & $\begin{array}{l}\text { Homo sapiens myosin light } \\
\text { chain kinase }\end{array}$ & 0.78 & Cytoplasm & kinase \\
\hline NUAK1 & $\begin{array}{l}\text { Homo sapiens NUAK family, } \\
\text { SNF1-like kinase, } 1\end{array}$ & 0.78 & Nucleus & kinase \\
\hline NPR3 & $\begin{array}{l}\text { Homo sapiens natriuretic } \\
\text { peptide receptor C/guanylate } \\
\text { cyclase C (atrionatriuretic } \\
\text { peptide receptor C) }\end{array}$ & 0.77 & $\begin{array}{l}\text { Plasma } \\
\text { Membrane }\end{array}$ & $\begin{array}{l}\text { G-protein } \\
\text { coupled } \\
\text { receptor }\end{array}$ \\
\hline PAWR & $\begin{array}{l}\text { Homo sapiens PRKC, } \\
\text { apoptosis, WT1, regulator }\end{array}$ & 0.75 & Nucleus & $\begin{array}{l}\text { transcription } \\
\text { regulator }\end{array}$ \\
\hline ANXA2P1 & $\begin{array}{l}\text { Homo sapiens annexin A2 } \\
\text { pseudogene } 1 \text { on chromosome } \\
4\end{array}$ & 0.74 & Other & other \\
\hline ITGA11 & $\begin{array}{l}\text { Homo sapiens integrin, alpha } \\
11\end{array}$ & 0.74 & $\begin{array}{l}\text { Plasma } \\
\text { Membrane }\end{array}$ & other \\
\hline CSRP1 & $\begin{array}{l}\text { Homo sapiens cysteine and } \\
\text { glycine-rich protein } 1\end{array}$ & 0.74 & Nucleus & other \\
\hline CAP2 & $\begin{array}{l}\text { Homo sapiens CAP, adenylate } \\
\text { cyclase-associated protein, } 2 \\
\text { (yeast) }\end{array}$ & 0.73 & $\begin{array}{l}\text { Plasma } \\
\text { Membrane }\end{array}$ & other \\
\hline TPM1 & $\begin{array}{l}\text { Homo sapiens tropomyosin } 1 \\
\text { (alpha), transcript variant } 3\end{array}$ & 0.71 & Cytoplasm & other \\
\hline HS.557431 & $\begin{array}{l}\text { RC3-BN0425-011200-022-c08 } \\
\text { BN0425 Homo sapiens cDNA }\end{array}$ & 0.7 & - & - \\
\hline
\end{tabular}




\begin{tabular}{|c|c|c|c|c|}
\hline COL8A1 & $\begin{array}{l}\text { Homo sapiens collagen, type } \\
\text { VIII, alpha } 1 \text {, transcript variant } \\
2\end{array}$ & 0.69 & $\begin{array}{l}\text { Extracellul } \\
\text { ar Space }\end{array}$ & other \\
\hline TLE2 & $\begin{array}{l}\text { Homo sapiens transducin-like } \\
\text { enhancer of split } 2\end{array}$ & 0.68 & Nucleus & $\begin{array}{l}\text { transcription } \\
\text { regulator }\end{array}$ \\
\hline HPS5 & $\begin{array}{l}\text { Homo sapiens Hermansky- } \\
\text { Pudlak syndrome } 5\end{array}$ & 0.68 & Cytoplasm & other \\
\hline PLOD2 & $\begin{array}{l}\text { Homo sapiens procollagen- } \\
\text { lysine, 2-oxoglutarate 5- } \\
\text { dioxygenase } 2\end{array}$ & 0.68 & Cytoplasm & enzyme \\
\hline LIMS2 & $\begin{array}{l}\text { Homo sapiens LIM and } \\
\text { senescent cell antigen-like } \\
\text { domains } 2\end{array}$ & 0.67 & Cytoplasm & other \\
\hline SEPT11 & Homo sapiens septin 11 & 0.67 & Nucleus & other \\
\hline TPD52L1 & $\begin{array}{l}\text { Homo sapiens tumor protein } \\
\text { D52-like } 1\end{array}$ & 0.67 & Cytoplasm & other \\
\hline PDLIM7 & $\begin{array}{l}\text { Homo sapiens PDZ and LIM } \\
\text { domain } 7 \text { (enigma) }\end{array}$ & 0.66 & Cytoplasm & other \\
\hline ALDH1L2 & $\begin{array}{l}\text { PREDICTED: Homo sapiens } \\
\text { aldehyde dehydrogenase } 1 \\
\text { family, member L2 }\end{array}$ & 0.65 & Cytoplasm & enzyme \\
\hline PID1 & $\begin{array}{l}\text { Homo sapiens phosphotyrosine } \\
\text { interaction domain containing } \\
1\end{array}$ & 0.64 & Cytoplasm & other \\
\hline RUSC2 & $\begin{array}{l}\text { Homo sapiens RUN and SH3 } \\
\text { domain containing } 2\end{array}$ & 0.64 & Cytoplasm & other \\
\hline ZNF365 & $\begin{array}{l}\text { Homo sapiens zinc finger } \\
\text { protein } 365\end{array}$ & 0.63 & Cytoplasm & other \\
\hline PCK2 & $\begin{array}{l}\text { Homo sapiens } \\
\text { phosphoenolpyruvate } \\
\text { carboxykinase } 2 \\
\text { (mitochondrial) }\end{array}$ & 0.62 & Cytoplasm & kinase \\
\hline THBS1 & $\begin{array}{l}\text { Homo sapiens thrombospondin } \\
1\end{array}$ & 0.61 & $\begin{array}{l}\text { Extracellul } \\
\text { ar Space }\end{array}$ & other \\
\hline CRABP2 & $\begin{array}{l}\text { Homo sapiens cellular retinoic } \\
\text { acid binding protein } 2\end{array}$ & 0.59 & Cytoplasm & transporter \\
\hline IL32 & Homo sapiens interleukin 32 & 0.57 & $\begin{array}{l}\text { Extracellul } \\
\text { ar Space }\end{array}$ & cytokine \\
\hline C1ORF198 & $\begin{array}{l}\text { Homo sapiens chromosome } 1 \\
\text { open reading frame } 198\end{array}$ & 0.57 & - & - \\
\hline HS3ST3A1 & $\begin{array}{l}\text { Homo sapiens heparan sulfate } \\
\text { (glucosamine) 3-O- } \\
\text { sulfotransferase 3A1 }\end{array}$ & 0.55 & Cytoplasm & enzyme \\
\hline HOXС8 & Homo sapiens homeobox C8 & 0.54 & Nucleus & $\begin{array}{l}\text { transcription } \\
\text { regulator }\end{array}$ \\
\hline SERAC1 & $\begin{array}{l}\text { Homo sapiens serine active site } \\
\text { containing } 1 .\end{array}$ & 0.51 & $\begin{array}{l}\text { Extracellul } \\
\text { ar Space }\end{array}$ & other \\
\hline
\end{tabular}




\begin{tabular}{|c|c|c|c|c|}
\hline CHI3L1 & $\begin{array}{l}\text { Homo sapiens chitinase } 3 \text {-like } \\
1\end{array}$ & -1.89 & $\begin{array}{l}\text { Extracellul } \\
\text { ar Space }\end{array}$ & enzyme \\
\hline ADH1A & $\begin{array}{l}\text { Homo sapiens alcohol } \\
\text { dehydrogenase } 1 \mathrm{~A} \text { (class I), } \\
\text { alpha polypeptide }\end{array}$ & -1.43 & Cytoplasm & enzyme \\
\hline MAFB & $\begin{array}{l}\text { Homo sapiens v-maf } \\
\text { musculoaponeurotic } \\
\text { fibrosarcoma oncogene } \\
\text { homolog B }\end{array}$ & -1.38 & Nucleus & $\begin{array}{l}\text { transcription } \\
\text { regulator }\end{array}$ \\
\hline CA12 & $\begin{array}{l}\text { Homo sapiens carbonic } \\
\text { anhydrase XII }\end{array}$ & -1.36 & $\begin{array}{l}\text { Plasma } \\
\text { Membrane }\end{array}$ & enzyme \\
\hline CYP1B1 & $\begin{array}{l}\text { Homo sapiens cytochrome } \\
\text { P450, family } 1 \text {, subfamily B, } \\
\text { polypeptide } 1\end{array}$ & -1.29 & Cytoplasm & enzyme \\
\hline МYВРН & $\begin{array}{l}\text { Homo sapiens myosin binding } \\
\text { protein } \mathrm{H}\end{array}$ & -1.28 & Cytoplasm & other \\
\hline RASD1 & $\begin{array}{l}\text { Homo sapiens RAS, } \\
\text { dexamethasone-induced } 1\end{array}$ & -1.22 & Cytoplasm & enzyme \\
\hline CXCL12 & $\begin{array}{l}\text { Homo sapiens chemokine (C- } \\
\text { X-C motif) ligand } 12 \text { (stromal } \\
\text { cell-derived factor } 1 \text { ) }\end{array}$ & -1.20 & $\begin{array}{l}\text { Extracellul } \\
\text { ar Space }\end{array}$ & cytokine \\
\hline ALDH1A3 & $\begin{array}{l}\text { Homo sapiens aldehyde } \\
\text { dehydrogenase } 1 \text { family, } \\
\text { member A3 }\end{array}$ & -1.12 & Cytoplasm & enzyme \\
\hline ADH1B & $\begin{array}{l}\text { Homo sapiens alcohol } \\
\text { dehydrogenase IB (class I), } \\
\text { beta polypeptide }\end{array}$ & -1.12 & Cytoplasm & enzyme \\
\hline OSR1 & $\begin{array}{l}\text { Homo sapiens odd-skipped } \\
\text { related } 1\end{array}$ & -1.10 & Nucleus & other \\
\hline PDGFRL & $\begin{array}{l}\text { Homo sapiens platelet-derived } \\
\text { growth factor receptor-like }\end{array}$ & -1.08 & $\begin{array}{l}\text { Plasma } \\
\text { Membrane }\end{array}$ & kinase \\
\hline GALNTL2 & $\begin{array}{l}\text { Homo sapiens UDP-N-acetyl- } \\
\text { alpha-D- } \\
\text { galactosamine:polypeptide N- } \\
\text { acetylgalactosaminyltransferas } \\
\text { e-like } 2\end{array}$ & -1.06 & Cytoplasm & enzyme \\
\hline COLEC12 & $\begin{array}{l}\text { Homo sapiens collectin sub- } \\
\text { family member } 12\end{array}$ & -1.05 & $\begin{array}{l}\text { Plasma } \\
\text { Membrane }\end{array}$ & $\begin{array}{l}\text { transmembra } \\
\text { ne receptor }\end{array}$ \\
\hline CLDN23 & Homo sapiens claudin 23 & -1.03 & $\begin{array}{l}\text { Plasma } \\
\text { Membrane }\end{array}$ & other \\
\hline CD14 & Homo sapiens CD14 molecule & -1.02 & $\begin{array}{l}\text { Plasma } \\
\text { Membrane }\end{array}$ & $\begin{array}{l}\text { transmembra } \\
\text { ne receptor }\end{array}$ \\
\hline C1R & $\begin{array}{l}\text { Homo sapiens complement } \\
\text { component } 1 \text {, r subcomponent }\end{array}$ & -1.01 & $\begin{array}{l}\text { Extracellul } \\
\text { ar Space }\end{array}$ & peptidase \\
\hline CTSC & Homo sapiens cathepsin C & -1.01 & Cytoplasm & peptidase \\
\hline TRAF3IP2 & $\begin{array}{l}\text { Homo sapiens TRAF3 } \\
\text { interacting protein } 2\end{array}$ & -0.97 & Cytoplasm & other \\
\hline
\end{tabular}




\begin{tabular}{|c|c|c|c|c|}
\hline PKIG & $\begin{array}{l}\text { Homo sapiens protein kinase } \\
\text { (cAMP-dependent, catalytic) } \\
\text { inhibitor gamma }\end{array}$ & -0.96 & Other & other \\
\hline FAM20A & $\begin{array}{l}\text { Homo sapiens family with } \\
\text { sequence similarity } 20 \text {, } \\
\text { member A }\end{array}$ & -0.95 & $\begin{array}{l}\text { Extracellul } \\
\text { ar Space }\end{array}$ & other \\
\hline SRPX & $\begin{array}{l}\text { Homo sapiens sushi-repeat- } \\
\text { containing protein, } \text { X-linked }\end{array}$ & -0.95 & Cytoplasm & other \\
\hline SLC9A9 & $\begin{array}{l}\text { Homo sapiens solute carrier } \\
\text { family } 9 \text { (sodium/hydrogen } \\
\text { exchanger), member } 9\end{array}$ & -0.95 & Cytoplasm & transporter \\
\hline AKR1C4 & $\begin{array}{l}\text { Homo sapiens aldo-keto } \\
\text { reductase family 1, member C4 } \\
\text { (chlordecone reductase; 3- } \\
\text { alpha hydroxysteroid } \\
\text { dehydrogenase, type I; } \\
\text { dihydrodiol dehydrogenase 4) }\end{array}$ & -0.93 & Cytoplasm & enzyme \\
\hline SCARA5 & $\begin{array}{l}\text { Homo sapiens scavenger } \\
\text { receptor class A, member } 5 \\
\text { (putative) }\end{array}$ & -0.93 & Cytoplasm & other \\
\hline ENPP2 & $\begin{array}{l}\text { Homo sapiens ectonucleotide } \\
\text { pyrophosphatase/phosphodiest } \\
\text { erase } 2\end{array}$ & -0.93 & $\begin{array}{l}\text { Plasma } \\
\text { Membrane }\end{array}$ & enzyme \\
\hline ANGPTL2 & $\begin{array}{l}\text { Homo sapiens angiopoietin- } \\
\text { like } 2\end{array}$ & -0.93 & $\begin{array}{l}\text { Extracellul } \\
\text { ar Space }\end{array}$ & other \\
\hline AKR1B10 & $\begin{array}{l}\text { Homo sapiens aldo-keto } \\
\text { reductase family 1, member } \\
\text { B10 (aldose reductase) }\end{array}$ & -0.91 & Cytoplasm & enzyme \\
\hline ALDH1A1 & $\begin{array}{l}\text { Homo sapiens aldehyde } \\
\text { dehydrogenase } 1 \text { family, } \\
\text { member A1 }\end{array}$ & -0.91 & Cytoplasm & enzyme \\
\hline ADORA1 & $\begin{array}{l}\text { Homo sapiens adenosine A1 } \\
\text { receptor }\end{array}$ & -0.87 & $\begin{array}{l}\text { Plasma } \\
\text { Membrane }\end{array}$ & $\begin{array}{l}\text { G-protein } \\
\text { coupled } \\
\text { receptor }\end{array}$ \\
\hline VWCE & $\begin{array}{l}\text { Homo sapiens von Willebrand } \\
\text { factor } C \text { and EGF domains }\end{array}$ & -0.86 & Other & other \\
\hline PCOLCE2 & $\begin{array}{l}\text { Homo sapiens procollagen C- } \\
\text { endopeptidase enhancer } 2\end{array}$ & -0.85 & $\begin{array}{l}\text { Extracellul } \\
\text { ar Space }\end{array}$ & other \\
\hline LDLR & $\begin{array}{l}\text { Homo sapiens low density } \\
\text { lipoprotein receptor (familial } \\
\text { hypercholesterolemia) }\end{array}$ & -0.84 & $\begin{array}{l}\text { Plasma } \\
\text { Membrane }\end{array}$ & transporter \\
\hline CLDN11 & $\begin{array}{l}\text { Homo sapiens claudin } 11 \\
\text { (oligodendrocyte } \\
\text { transmembrane protein) }\end{array}$ & -0.84 & $\begin{array}{l}\text { Plasma } \\
\text { Membrane }\end{array}$ & other \\
\hline RCAN2 & $\begin{array}{l}\text { Homo sapiens regulator of } \\
\text { calcineurin } 2\end{array}$ & -0.83 & Other & other \\
\hline CTSB & Homo sapiens cathepsin B & -0.82 & Cytoplasm & peptidase \\
\hline
\end{tabular}




\begin{tabular}{|c|c|c|c|c|}
\hline C10ORF10 & $\begin{array}{l}\text { Homo sapiens chromosome } 10 \\
\text { open reading frame } 10\end{array}$ & -0.82 & - & - \\
\hline KIAA1324L & Homo sapiens KIAA1324-like & -0.80 & Other & other \\
\hline PPAP2B & $\begin{array}{l}\text { Homo sapiens phosphatidic } \\
\text { acid phosphatase type } 2 \mathrm{~B}\end{array}$ & -0.79 & $\begin{array}{l}\text { Plasma } \\
\text { Membrane }\end{array}$ & phosphatase \\
\hline AKR1C2 & $\begin{array}{l}\text { Homo sapiens aldo-keto } \\
\text { reductase family 1, member C2 } \\
\text { (dihydrodiol dehydrogenase 2; } \\
\text { bile acid binding protein; 3- } \\
\text { alpha hydroxysteroid } \\
\text { dehydrogenase, type III) }\end{array}$ & -0.79 & Cytoplasm & enzyme \\
\hline PENK & Homo sapiens proenkephalin & -0.79 & $\begin{array}{l}\text { Extracellul } \\
\text { ar Space }\end{array}$ & other \\
\hline CFD & $\begin{array}{l}\text { Homo sapiens complement } \\
\text { factor D (adipsin) }\end{array}$ & -0.79 & $\begin{array}{l}\text { Extracellul } \\
\text { ar Space }\end{array}$ & peptidase \\
\hline DDIT4L & $\begin{array}{l}\text { Homo sapiens DNA-damage- } \\
\text { inducible transcript 4-like }\end{array}$ & -0.78 & Cytoplasm & other \\
\hline SNTB1 & $\begin{array}{l}\text { Homo sapiens syntrophin, beta } \\
1 \text { (dystrophin-associated } \\
\text { protein A1, 59kDa, basic } \\
\text { component } 1 \text { ) }\end{array}$ & -0.77 & $\begin{array}{l}\text { Plasma } \\
\text { Membrane }\end{array}$ & other \\
\hline C130RF33 & $\begin{array}{l}\text { Homo sapiens chromosome } 13 \\
\text { open reading frame } 33\end{array}$ & -0.76 & - & - \\
\hline LAMA4 & Homo sapiens laminin, alpha 4 & -0.76 & $\begin{array}{l}\text { Extracellul } \\
\text { ar Space }\end{array}$ & enzyme \\
\hline RNASE4 & $\begin{array}{l}\text { Homo sapiens ribonuclease, } \\
\text { RNase A family, } 4\end{array}$ & -0.76 & $\begin{array}{l}\text { Extracellul } \\
\text { ar Space }\end{array}$ & enzyme \\
\hline ALDH3A2 & $\begin{array}{l}\text { Homo sapiens aldehyde } \\
\text { dehydrogenase } 3 \text { family, } \\
\text { member A2 }\end{array}$ & -0.76 & Cytoplasm & enzyme \\
\hline PDPN & Homo sapiens podoplanin & -0.75 & $\begin{array}{l}\text { Plasma } \\
\text { Membrane }\end{array}$ & other \\
\hline RARRES3 & $\begin{array}{l}\text { Homo sapiens retinoic acid } \\
\text { receptor responder (tazarotene } \\
\text { induced) } 3\end{array}$ & -0.75 & Cytoplasm & enzyme \\
\hline LRRN4CL & $\begin{array}{l}\text { Homo sapiens LRRN4 C- } \\
\text { terminal like }\end{array}$ & -0.74 & Other & other \\
\hline IFI16 & $\begin{array}{l}\text { Homo sapiens interferon, } \\
\text { gamma-inducible protein } 16\end{array}$ & -0.74 & Nucleus & $\begin{array}{l}\text { transcription } \\
\text { regulator }\end{array}$ \\
\hline ABCA8 & $\begin{array}{l}\text { Homo sapiens ATP-binding } \\
\text { cassette, sub-family A } \\
\text { (ABC1), member } 8\end{array}$ & -0.74 & $\begin{array}{l}\text { Plasma } \\
\text { Membrane }\end{array}$ & transporter \\
\hline PPL & Homo sapiens periplakin & -0.73 & Cytoplasm & other \\
\hline DCN & Homo sapiens decorin & -0.71 & $\begin{array}{l}\text { Extracellul } \\
\text { ar Space }\end{array}$ & other \\
\hline
\end{tabular}




\begin{tabular}{|c|c|c|c|c|}
\hline PDGFRA & $\begin{array}{l}\text { Homo sapiens platelet-derived } \\
\text { growth factor receptor, alpha } \\
\text { polypeptide }\end{array}$ & -0.71 & $\begin{array}{l}\text { Plasma } \\
\text { Membrane }\end{array}$ & kinase \\
\hline CCBE1 & $\begin{array}{l}\text { Homo sapiens collagen and } \\
\text { calcium binding EGF domains } \\
1\end{array}$ & -0.71 & $\begin{array}{l}\text { Extracellul } \\
\text { ar Space }\end{array}$ & other \\
\hline IL1R1 & $\begin{array}{l}\text { Homo sapiens interleukin } 1 \\
\text { receptor, type I }\end{array}$ & -0.70 & $\begin{array}{l}\text { Plasma } \\
\text { Membrane }\end{array}$ & $\begin{array}{l}\text { transmembra } \\
\text { ne receptor }\end{array}$ \\
\hline MAFF & $\begin{array}{l}\text { Homo sapiens v-maf } \\
\text { musculoaponeurotic } \\
\text { fibrosarcoma oncogene } \\
\text { homolog F (avian) }\end{array}$ & -0.70 & Nucleus & $\begin{array}{l}\text { transcription } \\
\text { regulator }\end{array}$ \\
\hline FAM65C & $\begin{array}{l}\text { Homo sapiens family with } \\
\text { sequence similarity } 65 \text {, } \\
\text { member C }\end{array}$ & -0.70 & Other & other \\
\hline CTSL1 & Homo sapiens cathepsin L1 & -0.69 & Cytoplasm & peptidase \\
\hline BDKRB2 & $\begin{array}{l}\text { Homo sapiens bradykinin } \\
\text { receptor B2 }\end{array}$ & -0.69 & $\begin{array}{l}\text { Plasma } \\
\text { Membrane }\end{array}$ & $\begin{array}{l}\text { G-protein } \\
\text { coupled } \\
\text { receptor }\end{array}$ \\
\hline CPXM1 & $\begin{array}{l}\text { Homo sapiens } \\
\text { carboxypeptidase X (M14 } \\
\text { family), member } 1\end{array}$ & -0.68 & $\begin{array}{l}\text { Extracellul } \\
\text { ar Space }\end{array}$ & peptidase \\
\hline HLA-B & $\begin{array}{l}\text { Homo sapiens major } \\
\text { histocompatibility complex, } \\
\text { class I, B }\end{array}$ & -0.68 & $\begin{array}{l}\text { Plasma } \\
\text { Membrane }\end{array}$ & $\begin{array}{l}\text { transmembra } \\
\text { ne receptor }\end{array}$ \\
\hline UNC84A & $\begin{array}{l}\text { Homo sapiens unc-84 homolog } \\
\text { A (C. elegans) }\end{array}$ & -0.68 & Nucleus & other \\
\hline MARCKSL1 & $\begin{array}{l}\text { Homo sapiens MARCKS-like } \\
1\end{array}$ & -0.67 & Cytoplasm & other \\
\hline PROCR & $\begin{array}{l}\text { Homo sapiens protein C } \\
\text { receptor, endothelial (EPCR) }\end{array}$ & -0.67 & $\begin{array}{l}\text { Plasma } \\
\text { Membrane }\end{array}$ & other \\
\hline МАРЗК8 & $\begin{array}{l}\text { Homo sapiens mitogen- } \\
\text { activated protein kinase kinase } \\
\text { kinase } 8\end{array}$ & -0.67 & Cytoplasm & kinase \\
\hline RNF144 & $\begin{array}{l}\text { Homo sapiens ring finger } \\
\text { protein } 144\end{array}$ & -0.66 & Nucleus & other \\
\hline DUSP5 & $\begin{array}{l}\text { Homo sapiens dual specificity } \\
\text { phosphatase } 5\end{array}$ & -0.65 & Nucleus & phosphatase \\
\hline IFFO1 & $\begin{array}{l}\text { Homo sapiens intermediate } \\
\text { filament family orphan } 1\end{array}$ & -0.65 & Other & other \\
\hline ARHGEF3 & $\begin{array}{l}\text { Homo sapiens Rho guanine } \\
\text { nucleotide exchange factor } \\
\text { (GEF) } 3\end{array}$ & -0.64 & Cytoplasm & other \\
\hline $\begin{array}{l}\text { LOC1001343 } \\
04\end{array}$ & $\begin{array}{l}\text { PREDICTED: Homo sapiens } \\
\text { similar to hCG1983233 }\end{array}$ & -0.64 & - & - \\
\hline C160RF45 & $\begin{array}{l}\text { Homo sapiens chromosome } 16 \\
\text { open reading frame } 45\end{array}$ & -0.64 & - & - \\
\hline
\end{tabular}




\begin{tabular}{|c|c|c|c|c|}
\hline SIPA1L2 & $\begin{array}{l}\text { Homo sapiens signal-induced } \\
\text { proliferation-associated } 1 \text { like } \\
2\end{array}$ & -0.63 & Other & other \\
\hline TNFRSF21 & $\begin{array}{l}\text { Homo sapiens tumor necrosis } \\
\text { factor receptor superfamily, } \\
\text { member } 21\end{array}$ & -0.63 & $\begin{array}{l}\text { Plasma } \\
\text { Membrane }\end{array}$ & $\begin{array}{l}\text { transmembra } \\
\text { ne receptor }\end{array}$ \\
\hline HLA-F & $\begin{array}{l}\text { Homo sapiens major } \\
\text { histocompatibility complex, } \\
\text { class I, F }\end{array}$ & -0.62 & $\begin{array}{l}\text { Plasma } \\
\text { Membrane }\end{array}$ & $\begin{array}{l}\text { transmembra } \\
\text { ne receptor }\end{array}$ \\
\hline FYN & $\begin{array}{l}\text { Homo sapiens FYN oncogene } \\
\text { related to SRC, FGR, YES }\end{array}$ & -0.61 & $\begin{array}{l}\text { Plasma } \\
\text { Membrane }\end{array}$ & kinase \\
\hline CD59 & $\begin{array}{l}\text { Homo sapiens CD59 molecule, } \\
\text { complement regulatory protein }\end{array}$ & -0.61 & $\begin{array}{l}\text { Plasma } \\
\text { Membrane }\end{array}$ & other \\
\hline CDKN2C & $\begin{array}{l}\text { Homo sapiens cyclin- } \\
\text { dependent kinase inhibitor 2C } \\
\text { (p18, inhibits CDK4) }\end{array}$ & -0.60 & Nucleus & $\begin{array}{l}\text { transcription } \\
\text { regulator }\end{array}$ \\
\hline C1ORF21 & $\begin{array}{l}\text { Homo sapiens chromosome } 1 \\
\text { open reading frame } 21\end{array}$ & -0.59 & - & - \\
\hline STEAP1 & $\begin{array}{l}\text { Homo sapiens six } \\
\text { transmembrane epithelial } \\
\text { antigen of the prostate } 1\end{array}$ & -0.59 & $\begin{array}{l}\text { Plasma } \\
\text { Membrane }\end{array}$ & transporter \\
\hline PELI2 & $\begin{array}{l}\text { Homo sapiens pellino homolog } \\
2 \text { (Drosophila) }\end{array}$ & -0.57 & Cytoplasm & other \\
\hline PHKG1 & $\begin{array}{l}\text { Homo sapiens phosphorylase } \\
\text { kinase, gamma } 1 \text { (muscle) }\end{array}$ & -0.57 & Cytoplasm & kinase \\
\hline HLA-H & $\begin{array}{l}\text { Homo sapiens major } \\
\text { histocompatibility complex, } \\
\text { class I, H (pseudogene) }\end{array}$ & -0.56 & $\begin{array}{l}\text { Plasma } \\
\text { Membrane }\end{array}$ & other \\
\hline NTNG1 & Homo sapiens netrin G1 & -0.56 & $\begin{array}{l}\text { Extracellul } \\
\text { ar Space }\end{array}$ & other \\
\hline C1S & $\begin{array}{l}\text { Homo sapiens complement } \\
\text { component } 1 \text {, s subcomponent }\end{array}$ & -0.56 & $\begin{array}{l}\text { Extracellul } \\
\text { ar Space }\end{array}$ & peptidase \\
\hline ZCCHC14 & $\begin{array}{l}\text { Homo sapiens zinc finger, } \\
\text { CCHC domain containing } 14\end{array}$ & -0.54 & Other & other \\
\hline PSMB8 & $\begin{array}{l}\text { Homo sapiens proteasome } \\
\text { (prosome, macropain) subunit, } \\
\text { beta type, } 8 \text { (large } \\
\text { multifunctional peptidase 7) }\end{array}$ & -0.54 & Cytoplasm & peptidase \\
\hline SASH1 & $\begin{array}{l}\text { Homo sapiens SAM and SH3 } \\
\text { domain containing } 1\end{array}$ & -0.53 & $\begin{array}{l}\text { Extracellul } \\
\text { ar Space }\end{array}$ & other \\
\hline
\end{tabular}

Supplementary Table 2. Two donor gene co-regulation in tendon-derived cells co-cultured with myoblasts for 7 days. 


\section{REFERENCES}

1. Mall NA, Chalmers PN, Moric M, Tanaka MJ, Cole BJ, Bach BR, Jr., Paletta GA, Jr.: Incidence and trends of anterior cruciate ligament reconstruction in the United States. The American journal of sports medicine 2014, 42(10):23632370.

2. Shaerf DA, Pastides PS, Sarraf KM, Willis-Owen CA: Anterior cruciate ligament reconstruction best practice: A review of graft choice. World journal of orthopedics 2014, 5(1):23-29.

3. Schweitzer R, Zelzer E, Volk T: Connecting muscles to tendons: tendons and musculoskeletal development in flies and vertebrates. Development 2010, 137(17):2807-2817.

4. Hendriks, J., Riesle, J., andVanblitterswijk, C.A. Effect of stratified culture compared to confluent culture in monolayer on proliferation and differentiation of human articular chondrocytes. Tissue Eng 12, 2397, 2006.

5. Ghebes, C.A., Kelder, C., Schot, T., Renard, A.J., Pakvis, D.F., Fernandes, H., andSaris, D.B. Anterior cruciate ligament- and hamstring tendon-derived cells: in vitro differential properties of cells involved in ACL reconstruction. Journal of tissue engineering and regenerative medicine 2015.

6. Mentink A, Hulsman M, Groen N, Licht R, Dechering KJ, van der Stok J, Alves HA, Dhert WJ, van Someren EP, Reinders MJT et al: Predicting the therapeutic efficacy of MSC in bone tissue engineering using the molecular marker CADM1. Biomaterials 2013, 34(19):4592-4601.

7. Le BQ, Fernandes H, Bouten CV, Karperien M, van Blitterswijk C, de Boer J: High-Throughput Screening Assay for the Identification of Compounds Enhancing Collagenous Extracellular Matrix Production by ATDC5 Cells. Tissue engineering Part C, Methods 2015.

8. Unadkat HV, Rewagad RR, Hulsman M, Hulshof GF, Truckenmuller RK, Stamatialis DF, Reinders MJ, Eijkel JC, van den Berg A, van Blitterswijk CA et al: A modular versatile chip carrier for high-throughput screening of cellbiomaterial interactions. Journal of the Royal Society, Interface / the Royal Society 2013, 10(78):20120753.

9. Barradas AM, Lachmann K, Hlawacek G, Frielink C, Truckenmoller R, Boerman OC, van Gastel R, Garritsen H, Thomas M, Moroni L et al: Surface modifications by gas plasma control osteogenic differentiation of MC3T3-E1 cells. Acta biomaterialia 2012, 8(8):2969-2977.

10. Gentleman RC, Carey VJ, Bates DM, Bolstad B, Dettling M, Dudoit S, Ellis B, Gautier L, Ge Y, Gentry J et al: Bioconductor: open software development for computational biology and bioinformatics. Genome biology 2004, 5(10):R80.

11. Smyth GK: limma: Linear Models for Microarray Data. In: Bioinformatics and Computational Biology Solutions Using $R$ and Bioconductor. Edited by Gentleman R, Carey VJ, Huber W, Irizarry RA, Dudoit S. New York, NY: Springer New York; 2005: 397-420.

12. Benjamini Y, Hochberg Y: Controlling the False Discovery Rate: A Practical and Powerful Approach to Multiple Testing.

13. Huang da W, Sherman BT, Lempicki RA: Systematic and integrative analysis of large gene lists using DAVID bioinformatics resources. Nature protocols 2009, 4(1):44-57.

14. Huang da W, Sherman BT, Lempicki RA: Bioinformatics enrichment tools: paths toward the comprehensive functional analysis of large gene lists. Nucleic acids research 2009, 37(1):1-13.

15. Fu SC, Cheng WH, Cheuk YC, Mok TY, Rolf CG, Yung SH, Chan KM: Effect of graft tensioning on mechanical restoration in a rat model of anterior cruciate ligament reconstruction using free tendon graft. Knee surgery, sports traumatology, arthroscopy : official journal of the ESSKA 2013, 21(5):1226-1233.

16. Fu S-C, Cheng W-H, Cheuk Y-C, Mok T-Y, Rolf C, Yung S-H, Chan K-M: Development of vitamin C irrigation saline to promote graft healing in anterior cruciate ligament reconstruction. Journal of Orthopaedic Translation 2013, 1(1):67-77

17. Claes S, Verdonk P, Forsyth R, Bellemans J: The "ligamentization" process in anterior cruciate ligament reconstruction: what happens to the human graft? A systematic review of the literature. The American journal of sports medicine 2011, 39(11):2476-2483. 


\section{Chapter 4}

18. Pauzenberger L, Syre S, Schurz M: "Ligamentization" in hamstring tendon grafts after anterior cruciate ligament reconstruction: a systematic review of the literature and a glimpse into the future. Arthroscopy : the journal of arthroscopic \& related surgery : official publication of the Arthroscopy Association of North America and the International Arthroscopy Association 2013, 29(10):1712-1721.

19. Edom-Vovard F, Duprez D: Signals regulating tendon formation during chick embryonic development. Developmental dynamics : an official publication of the American Association of Anatomists 2004, 229(3):449-457.

20. Murchison ND, Price BA, Conner DA, Keene DR, Olson EN, Tabin CJ, Schweitzer R: Regulation of tendon differentiation by scleraxis distinguishes force-transmitting tendons from muscle-anchoring tendons. Development 2007, 134(14):2697-2708.

21. Schurch W, Seemayer TA, Gabbiani G: The myofibroblast: a quarter century after its discovery. The American journal of surgical pathology 1998, 22(2):141-147.

22. Faryniarz DA, Chaponnier C, Gabbiani G, Yannas IV, Spector M: Myofibroblasts in the healing lapine medial collateral ligament: possible mechanisms of contraction. Journal of orthopaedic research : official publication of the Orthopaedic Research Society 1996, 14(2):228-237.

23. Eyre DR: Collagens and cartilage matrix homeostasis. Clinical orthopaedics and related research $2004(427$ Suppl):S118-122.

24. Tchetina E, Mwale F, Poole AR: Distinct phases of coordinated early and late gene expression in growth plate chondrocytes in relationship to cell proliferation, matrix assembly, remodeling, and cell differentiation. Journal of bone and mineral research : the official journal of the American Society for Bone and Mineral Research 2003, 18(5):844851.

25. Sahebjam S, Khokha R, Mort JS: Increased collagen and aggrecan degradation with age in the joints of Timp3(-/-) mice. Arthritis Rheum 2007, 56(3):905-909.

26. Ochi K, Derfoul A, Tuan RS: A predominantly articular cartilage-associated gene, SCRG1, is induced by glucocorticoid and stimulates chondrogenesis in vitro. Osteoarthritis Cartilage 2006, 14(1):30-38.

27. Hakala BE, White C, Recklies AD: Human cartilage gp-39, a major secretory product of articular chondrocytes and synovial cells, is a mammalian member of a chitinase protein family. The Journal of biological chemistry 1993, 268(34):25803-25810.

28. Chou CH, Lee MT, Song IW, Lu LS, Shen HC, Lee CH, Wu JY, Chen YT, Kraus VB, Wu CC: Insights into osteoarthritis progression revealed by analyses of both knee tibiofemoral compartments. Osteoarthritis Cartilage 2015, 23(4):571-580.

29. Lo SH: Tensin. Int J Biochem Cell Biol 2004, 36(1):31-34.

30. Rockey DC, Weymouth N, Shi Z: Smooth muscle alpha actin (Acta2) and myofibroblast function during hepatic wound healing. PloS one 2013, 8(10):e77166.

31. Wittamer V, Franssen JD, Vulcano M, Mirjolet JF, Le Poul E, Migeotte I, Brezillon S, Tyldesley R, Blanpain C, Detheux $\mathrm{M}$ et al: Specific recruitment of antigen-presenting cells by chemerin, a novel processed ligand from human inflammatory fluids. The Journal of experimental medicine 2003, 198(7):977-985.

32. Kpetemey M, Dasgupta S, Rajendiran S, Das S, Gibbs LD, Shetty P, Gryczynski Z, Vishwanatha JK: MIEN1, a novel interactor of Annexin A2, promotes tumor cell migration by enhancing AnxA2 cell surface expression. Molecular cancer 2015, 14:156.

33. Nabiev SR, Ovsyannikov DA, Kopylova GV, Shchepkin DV, Matyushenko AM, Koubassova NA, Levitsky DI, Tsaturyan AK, Bershitsky SY: Stabilizing the central part of tropomyosin increases the bending stiffness of the thin filament. Biophysical journal 2015, 109(2):373-379.

34. Park CH, Rha SY, Ahn JB, Shin SJ, Kwon WS, Kim TS, An S, Kim NK, Yang WI, Chung HC: PINCH-2 presents functional copy number variation and suppresses migration of colon cancer cells by paracrine activity. International journal of cancer 2015, 136(10):2273-2283.

35. Pal SK, Nguyen CT, Morita KI, Miki Y, Kayamori K, Yamaguchi A, Sakamoto K: THBS1 is induced by TGFB1 in the cancer stroma and promotes invasion of oral squamous cell carcinoma. Journal of oral pathology \& medicine : official publication of the International Association of Oral Pathologists and the American Academy of Oral Pathology 2016. 
36. Izumi D, Ishimoto T, Miyake K, Sugihara H, Eto K, Sawayama H, Yasuda T, Kiyozumi Y, Kaida T, Kurashige J et al: CXCL12/CXCR4 activation by cancer-associated fibroblasts promotes integrin beta1 clustering and invasiveness in gastric cancer. International journal of cancer 2016, 138(5):1207-1219.

37. Leblanc R, Lee SC, David M, Bordet JC, Norman DD, Patil R, Miller D, Sahay D, Ribeiro J, Clezardin P et al: Interaction of platelet-derived autotaxin with tumor integrin alphaVbeta3 controls metastasis of breast cancer cells to bone. Blood 2014, 124(20):3141-3150.

38. Aeffner F, Woods PS, Davis IC: Activation of A1-adenosine receptors promotes leukocyte recruitment to the lung and attenuates acute lung injury in mice infected with influenza A/WSN/33 (H1N1) virus. Journal of virology 2014, 88(17):10214-10227.

39. Shan N, Zhang X, Xiao X, Zhang H, Tong C, Luo X, Chen Y, Liu X, Yin N, Deng Q et al: Laminin alpha4 (LAMA4) expression promotes trophoblast cell invasion, migration, and angiogenesis, and is lowered in preeclamptic placentas. Placenta 2015, 36(8):809-820.

40. Grau SJ, Trillsch F, Tonn JC, Goldbrunner RH, Noessner E, Nelson PJ, von Luettichau I: Podoplanin increases migration and angiogenesis in malignant glioma. International journal of clinical and experimental pathology 2015, 8(7):8663-8670.

41. MacDonald TJ, Brown KM, LaFleur B, Peterson K, Lawlor C, Chen Y, Packer RJ, Cogen P, Stephan DA: Expression profiling of medulloblastoma: PDGFRA and the RAS/MAPK pathway as therapeutic targets for metastatic disease. Nature genetics 2001, 29(2):143-152.

42. Deshmane SL, Kremlev S, Amini S, Sawaya BE: Monocyte chemoattractant protein-1 (MCP-1): an overview. Journal of interferon \& cytokine research : the official journal of the International Society for Interferon and Cytokine Research 2009, 29(6):313-326.

43. Engsig MT, Chen QJ, Vu TH, Pedersen AC, Therkidsen B, Lund LR, Henriksen K, Lenhard T, Foged NT, Werb Z et al: Matrix metalloproteinase 9 and vascular endothelial growth factor are essential for osteoclast recruitment into developing long bones. The Journal of cell biology 2000, 151(4):879-889.

44. Maghazachi AA, Al-Aoukaty A, Schall TJ: CC chemokines induce the generation of killer cells from CD56+ cells. European journal of immunology 1996, 26(2):315-319.

45. Phillips BB: Arthroscopy of the lower extremity. In: Campbell's Operative Orthopaedics. Edited by Canale ST, Beaty JH, vol. 11th edn. Philadelphia; 2008: 2869.

46. Murray MM, Spector M: Fibroblast distribution in the anteromedial bundle of the human anterior cruciate ligament: the presence of alpha-smooth muscle actin-positive cells. Journal of orthopaedic research : official publication of the Orthopaedic Research Society 1999, 17(1):18-27.

47. Sun L, Hou C, Wu B, Tian M, Zhou X: Effect of muscle preserved on tendon graft on intra-articular healing in anterior cruciate ligament reconstruction. Knee surgery, sports traumatology, arthroscopy : official journal of the ESSKA 2013, 21(8):1862-1868. 



\section{Chapter 5}

\section{High-Throughput Screening Assay Identifies Small Molecules Capable of Modulating the BMP-2 and TGF-p1 Signalling Pathway}

Ghebeş C.A., van Lente J., Post J.N., Saris D.B.F. and Fernandes H.A.M. 


\section{AbstRact}

Modulating the bone morphogenetic protein 2 (BMP-2) and transforming growth factor- $\beta 1$ (TGF- $\beta 1$ ) signalling pathways is essential during tendon/ligament (T/L) healing. Unfortunately, growth factor delivery in situ is far from trivial and, in many cases, the necessary growth factors are not approved for clinical use. Here we used a BMP-2 and a TGF- $\beta 1$ reporter cell line to screen a library of 1280 Food and Drug Administration-approved small molecules and identify modulators of both signalling pathways. We identified four compounds capable of modulating BMP and TGF signalling on primary human tendon-derived cells (huTCs) and describe their effects on proliferation and differentiation of these cells. 


\section{INTRODUCTION}

Despite significant advances in unravelling the mechanisms governing tendon/ligament (T/L) healing and improving the clinical management of these injuries, the outcome is far from ideal. Animal and cellular models developed to identify the molecular drivers of $\mathrm{T} / \mathrm{L}$ healing and repair lend evidence to the importance of specific growth factors in the process. Secreted growth factors (GFs) such as bone morphogenetic protein (BMP) and transforming growth factor- $\beta$ (TGF- $\beta$ ) have been identified as key players in the process of $\mathrm{T} / \mathrm{L}$ specification during embryonic development as well as on the healing and repair upon injury [1, 2]. Several reports demonstrated that GFs promoted cell differentiation, upregulated cartilage/bone markers known to be involved in enthesis formation and induce cytoskeletal organization, thus contributing to the restoration of tissue strength and functionality [3-5]. Nonetheless, the concentration and spatial distribution of these endogenous GFs during T/L healing are not sufficient to shorten the repair period that may take from several months to a year [6]. In an attempt to overcome these limitations, several groups suggested that a combination of scaffolds and recombinant human GFs, such as rhTGF- $\beta 1$ and rhBMP-2, could accelerate T/L healing $[7,8]$. However, even though recombinant human material has shown great potential in tissue regeneration, their biological nature poses several challenges for their production regarding batch variability, stability, biological activity, and production costs [9], emphasizing the need for an alternative such as the identification and/or development of small molecules with the desired biological properties.

Consequently, we screened a library of 1,280 Food and Drug Administration (FDA)approved small molecules using a BMP-2 and a TGF- $\beta 1$ reporter cell line and identified small molecules capable of modulating both pathways. Subsequent assays used human tendon-derived cells (huTCs) to investigate the effect of the selected molecules in huTC metabolism as well as differentiation potential. A schematic overview of the experiment design is represented in Figure 1.

\section{MATERIALS AND METHODS}

\section{Cell types}

Mink lung epithelial cells (MLEC) previously transfected with a reporter plasmid consisting of TGF- $\beta$-responsive elements from the PAI- 1 promoter fused to a luciferase reporter gene [10], and C2C12 transfected with a reporter plasmid consisting of BMPresponsive elements from the Id1 promoter fused to a luciferase reporter gene [11] were a generous gift from DB Rifkin.

huTCs were isolated from human hamstring tendon tissue using $0.15 \%(\mathrm{w} / \mathrm{v})$ collagenase type II solution (Worthington) digestion in basic media (see below) as previously described [12]. The collection and anonymous use of the tissue was performed 


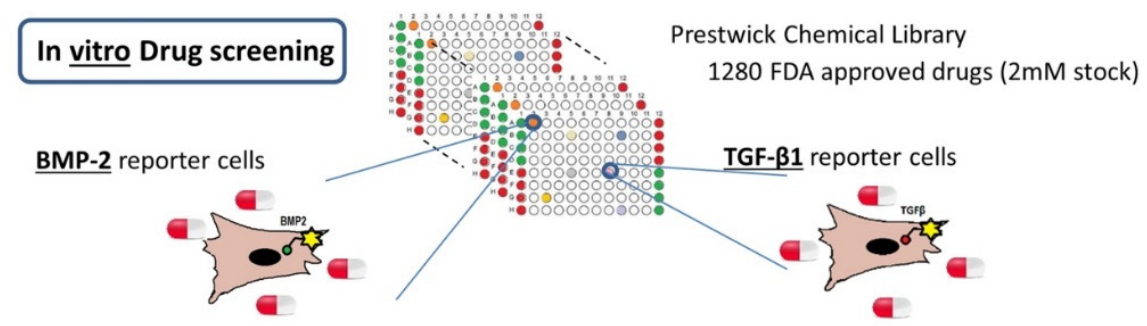

In vitro Hit validation

Concentration dependent hit confirmation using BMP-2 \& TGF- $\beta 1$ reporter cells

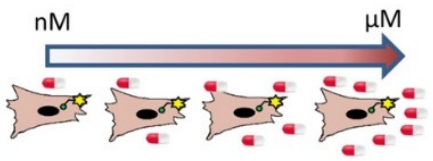

Metabolic activity of human tendon-derived cells

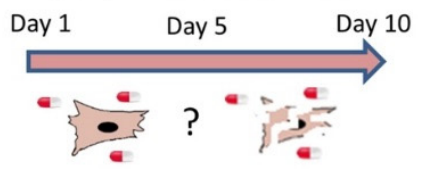

mRNA expression of a panel of genes in human tendon-derived cells
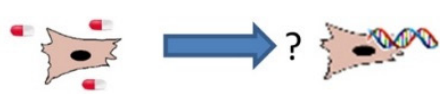

BMP-2 target genes for BMP-2 drug modulators

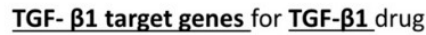
modulators

Smad nuclear translocation in human tendon-derived cells

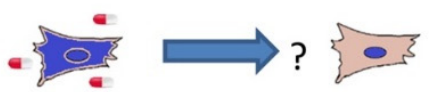

SMAD 1/5/8 for BMP-2 drug modulators

$\underline{\text { SMAD 2/3 for TGF- } \beta 1 \text { drug }}$ modulators

Cell differentiation / Matrix production of human tendon-derived cells

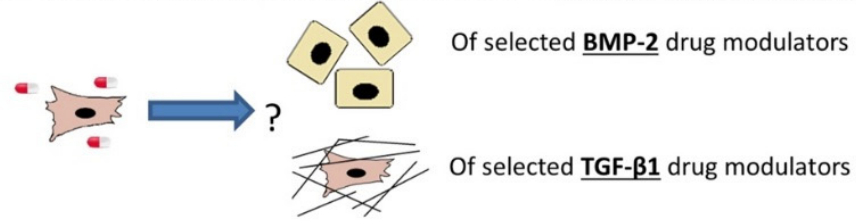

Figure 1. Schematic overview of the experimental design. 
according to the medical ethical regulations and the guideline 'good use of redundant tissue for research of the Dutch Federation of Medical Research Societies'.

All cells were cultured in basic media (BM) consisting of DMEM (Gibco) supplemented with 10\% fetal bovine serum (FBS) (Gibco), $100 \mathrm{U} / \mathrm{ml}$ penicillin and 100 $\mu \mathrm{g} / \mathrm{ml}$ streptomycin (Gibco) and $0.2 \mathrm{mM}$ ascorbic acid (Sigma).

\section{Small-molecule high throughput screening}

The Prestwick Chemical Library consisting of 1,280 FDA-approved small molecules (Prestwick Chemical, Inc.) was dissolved in DMSO to a final concentration of $2 \mathrm{mM}$.

BMP-2 reporter cells were seeded onto 96-well cell culture plates at 10,000 cells/well in $\mathrm{BM}$ and allowed to attach for 24 hours at $37^{\circ} \mathrm{C}, 5 \% \mathrm{CO}_{2}$ and $95 \%$ humidity. Small molecules were then added to the wells at a final concentration of $5 \mu \mathrm{M}$ and DMSO treated cells were used as negative control, while cells treated with $2.5 \mathrm{nM}$ rhBMP2 were used as a positive control. Cells were further cultured for 24 hours upon which media containing the small molecules was removed, cells were washed one time with PBS and Luciferase assay (Promega) was used per the manufacturer's protocol.

Similarly, TGF- $\beta 1$ reporter cells were seeded onto 96-well cell culture plates at 20,000 cells/well and allowed to attach for 24 hours at $37^{\circ} \mathrm{C}, 5 \% \mathrm{CO}_{2}$ and $95 \%$ humidity. Small molecules were then added to a final concentration of $5 \mu \mathrm{M}$ and DMSO treated cells were used as the negative control, while cells treated with $0.8 \mathrm{nM}$ rhTGF- $\beta 1$ were used as positive control. Cells were further cultured for 24 hours upon which media containing small molecules was removed, cells were washed one time with PBS and Luciferase assay (Promega) was used per the manufacturer's protocol.

Luminescence was read at $590 \mathrm{~nm}$ on a Victor plate reads (Perkin Elmer, Wellesley, MA) and reported as relative light units (RLU). A hit was identified if, upon exposure to a small molecule, the resulting luciferase activity was at least 2 times higher than the negative control. Small molecules that fulfilled this threshold were purchased from Prestwick Chemical, Inc. and retested in a dose-dependent manner (from nM to $\mu \mathrm{M}$ ) under the same seeding and culture conditions. The compounds showing an increased luciferase activity compared to the negative control were selected for further investigation using huTCs.

\section{Metabolic activity}

huTCs were seeded on 96-well cell culture plates at 4,000 cells/well in BM and allowed to attach for 24 hours. The next day, cells were treated with different concentrations of the selected compounds in a dose-dependent manner (from nM to $\mu \mathrm{M}$ ). After 1, 5, and 10 days metabolic activity was measured after incubation for 1 hour with $10 \%(\mathrm{v} / \mathrm{v})$ Presto Blue Cell Viability Reagent (Invitrogen) in BM and absorbance was measured at $590 \mathrm{~nm}(\mathrm{n}=3)$. 


\section{Gene expression analysis}

huTCs were seeded on 6-well cell culture plates at 50,000 cells/well in BM and cultured until confluent. BM was then replaced with starvation media (SM) consisting of BM without FBS and further cultured for 24 hours upon which the selected compounds were added in BM for further 24 hours.

Total RNA was isolated using the NucleoSpin RNA II isolation kit (Macherey-Nagel), per the manufacturer's instructions. RNA was collected in RNase-free water and a quantitative analysis was performed using spectrophotometry (Nanodrop). First-strand cDNA was synthesized from $0.6 \mu \mathrm{g}$ total RNA/sample, using iScript (BioRad) per the manufacturer's instructions. PCR was performed on a real-time PCR detection system (Biorad), using iQ Syber green supermix (BioRad) for different genes, as presented in Table 1, or TaqMan Universal MasterMix for B2M and scleraxis (SCX). Gene expression was normalized to the reference gene B2M and fold induction calculated using the $\Delta \Delta \mathrm{Ct}$ method, presented on a Log2 scale.

\begin{tabular}{ll}
\hline Target Genes & Primer Sequence \\
\hline B2M & 5' -GACTTGTCTTTCAGCAAGGA \\
COL IA1 & 5' -ACAAAGTCACATGGTTCACA \\
& 5'-GTCACCCACCGACCAAGAAACC \\
COL IIIA1 & 5'-AAGTCCAGGCTGTCCAGGGATG \\
& 5'-AACACGCGCCACACCAAATT \\
TNC & 5'-TGGGCAGATTTCACGGGGTG \\
& 5'-TGCTCTGAGCCCGAATGTC \\
TIMP1 & 5' -CTTCTGCAATTCCGACCTCGT \\
& 5' -ACGCTGGTATAAGGTGGTCTG \\
TIMP3 & 5' -CCAGGACGCCTTCTGCAAC \\
& 5' -CCTCCTTTACCAGCTTCTTCCC \\
MMP1 & 5' -GGGAGATCATCGGGACAACTC \\
& 5' -GGGCCTGGTTGAAAAGCAT \\
MMP3 & 5' -TGGCATTCAGTCCCTCTATGG \\
& 5' -AGGACAAAGCAGGATCACAGTT \\
BMP-2 & 5' -GCTAGACCTGTATCGCAGGC \\
& 5' -TTTTCCCACTCGTTTCTGGT \\
BMP-4 & 5' -AGCGTAGCCCTAAGCATCAC \\
& 5' -AGTCATTCCAGCCCACATCG \\
ALPL & 5' -ACTGGTACTCAGACAACGAGAT \\
& 5' -ACGTCAATGTCCCTGATGTTATG \\
RUNX2 & 5' -GGAGTGGACGAGGCAAGAGTTT \\
& 5' -AGCTTCTGTCTGTGCCTTCTGG \\
\hline
\end{tabular}

Table 1. Primers used for Real-Time Polymerase Chain Reaction Analysis 


\section{SMAD2/3 and SMAD 1/5/8 nuclear translocation}

huTCs were seeded on 96-well cell culture plates at 5,000 cells/well in BM and allowed to attach for 24 hours. The next day, BM was replaced with SM for 5 hours followed by 30 minutes or 2 hours incubation in $\mathrm{BM}$ in the presence of quinacrine $(5 \mu \mathrm{M})$, niclosamide $(100,500 \mathrm{nM}$ or $1 \mu \mathrm{M})$, vorinostat $(5,10 \mu \mathrm{M})$ or hycanthone $(5,10 \mu \mathrm{M})$. Cells exposed to $2.5 \mathrm{nM}$ rhBMP-2 or $0.2 \mathrm{nM}$ rhTGF- $\beta 1$ were considered as positive control. Following, the cells were washed with PBS and fixed with $10 \%$ formalin solution neutral buffered (Sigma) for 15 minutes, after which they were stained either for SMAD2/3 (for TGF- $\beta$ mediated translocation) or SMAD1/5/8 (for BMP mediated translocation). Fixed cells were permeabilised with $0.2 \%(\mathrm{v} / \mathrm{v})$ Triton X-98 in PBS for 15 minutes and then blocked in $0.2 \%(\mathrm{v} / \mathrm{v})$ bovine serum albumin $/ 0.2 \%$ Triton $\mathrm{X}$ 98/PBS for 1 hour. The primary antibody against SMAD2/3 (mouse anti-smad2/3, BD Bioscience) or SMAD1/5/8 (rabbit anti-smad1/5/8, Santa Cruz Biotechnology) were used at a dilution of $1: 200$ in $0.2 \%$ bovine serum albumin/PBS and incubated for 3 hours. The secondary antibody Alexa Fluor 546 goat anti-mouse (Life Technologies) was used against SMAD2/3 and Alexa Fluor 549 goat anti-rabbit (Invitrogen) was used against SMAD1/5/8 at a dilution of 1: 200 in $0.2 \%$ bovine serum albumin/PBS for 1 hour in the dark. Afterwards, cells were counterstained with $2.8 \mathrm{mM}$ DAPI (Invitrogen) in $0.2 \%$ bovine serum albumin/PBS for 15 minutes, upon which cells were washed with PBS. All incubation steps were performed under orbital shaking and at ambient room temperature.

Fluorescence images were taken using BD Pathway 435 after adjusting the staining intensity to the isotype (secondary antibody alone) and quantification of SMAD nuclear translocation was assessed using CellProfiler open source software [13]. Following, the integrated intensity measured both for the cytoplasmic and the nuclear SMAD was used to calculate the ratio nucleus:cytoplasm SMAD.

\section{Alkaline phosphatase activity}

huTCs were seeded on 12-well cell culture plates at 50,000 cells/well in BM. The next day, BM was replaced with fresh media and $100 \mathrm{nM}$ niclosamide or $4 \mathrm{nM}$ rhBMP-2 was added to the wells $(n=3)$. Cells were cultured for 7 days with one media change at day 3 . At day 7, cells were fixed in $10 \%$ formalin solution neutral buffered (Sigma) for 15 minutes and stained using the Leukocyte Alkaline Phosphatase Kit -ALP (Sigma, 85L2$1 \mathrm{KT}$ ) following the manufacturer's instructions. Images of the stained wells were acquired using an Epson Perfection V750 PRO scanner and quantification was assessed using FIJI open source software [14]. Equal sized squares were cropped from the wells, converted to 8-bit and background subtracted using the rolling ball radius function. The image was then converted into binary, the area of ALP staining was selected and the total number of pixels measured (Supplementary Figure 1). 


\section{Collagen content analysis}

huTCs were seeded on 6-well cell culture plates at 50,000 cells/well in BM and cultured until confluent, upon which media was refreshed and vorinostat (5 and $10 \mu \mathrm{M})$ or 0.2 $\mathrm{nM}$ rhTGF- $\beta 1$ was added to the wells $(n=3)$. Vorinostat or rhTGF- $\beta 1$ were freshly added every three days when media was refreshed and at day 10 , cells were fixed in $10 \%$ formalin for 15 minutes at room temperature and stained for collagen deposition using the Picrosirius red stain kit (Polyscience Inc.) following the manufacturer's instructions. Images of the stained wells were acquired and quantified using FIJI open source software as described above.

\section{Statistical analysis}

Statistical analysis was performed using Graphpad Prism 6 software. Two-way ANOVA and a Tukey post hoc test were used to compare the different conditions. A value of $\mathrm{p} \leq 0.05$ indicates a statistical significant difference. Results are shown as mean \pm standard deviation.

\section{RESULtS}

\section{Identification and validation of small molecules capable of modulating TGF- $\beta 1$ and BMP-2 reporter cell lines}

A library of 1,280 FDA-approved small molecules was screened to identify modulators of BMP-2 and TGF- $\beta 1$ signaling. BMP-2 and TGF- $\beta$ reporter cell lines were exposed for 24 hours to the small molecules $(5 \mu \mathrm{M})$ and hits were selected if a compounds' luciferase activity was at least two times higher than the negative controls. Seven BMP2 and three TGF- $\beta 1$ small molecules were identified as primary hits. Pirlindole mesylate, pramipexole, nylidrin, butylscopolammonium (n-) bromide, quinacrine dihydrochloride dehydrate (quinacrine), chlorhexidine and niclosamide were identified as modulators of the BMP-2 reporter cell line, whereas hycanthone, etoposide and vorinostat were identified as modulators of the TGF- $\beta 1$ reporter cell line (Figure $2 \mathrm{~A}, \mathrm{C}$ and Supplementary Figure 2).

Subsequently, dose-response curves ( $1 \mathrm{nM}$ to $100 \mu \mathrm{M}, \mathrm{n}=3$ ) were generated for the selected primary hits. Quinacrine and niclosamide were validated as potential BMP-2 modulators, while hycanthone and vorinostat were validated as potential TGF- $\beta 1$ modulators (Figure 2B, D).

\section{Effect of the validated hits on metabolic activity of huTCs}

Given that our final goal is to use the identified hits for T/L regeneration, we tested the identified hits on huTCs previously isolated and described [12]. To that end, a time dependent dose-response curve was performed and metabolic activity was measured at 
BMP-2 reporter cells

A

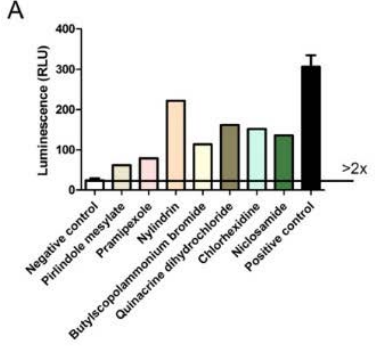

TGF- $\beta 1$ reporter cells

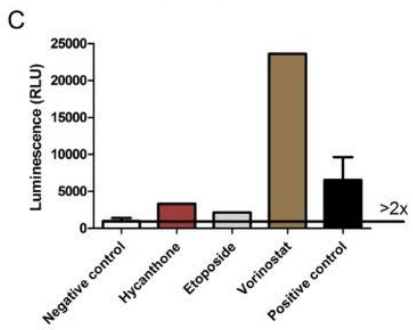

B

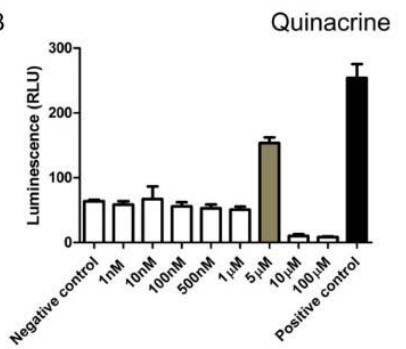

D

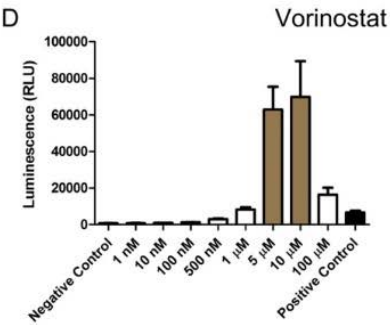

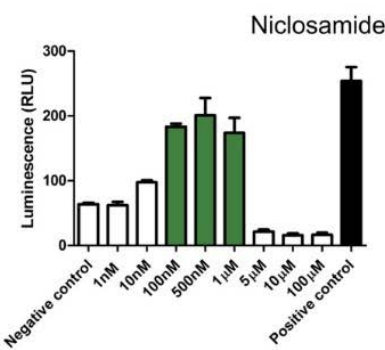

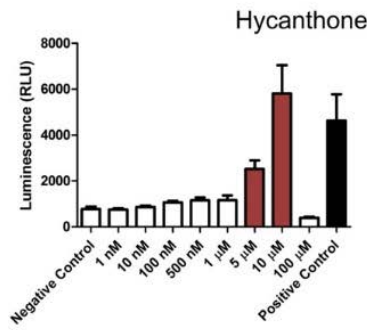

Figure 2. Small-molecule library screening for BMP-2 and TGF- $\beta 1$ modulators. BMP-2 and TGF- $\beta 1$ reporter cell lines were independently plated on to 96-well cell culture plates and compounds were added for 24 hours at a concentration of $5 \mu \mathrm{M}$, after which cells where lysed and luciferase activity measured. Positive control are cells cultured in the presence of $2.5 \mathrm{nM}$ rhBMP-2 or $0.8 \mathrm{nM}$ rhTGF- $\beta 1$, while negative control are cells cultured in basic media. A hit was identified if, upon exposure to a small molecule, the resulting luciferase activity was at least 2 times higher than the negative control. (A) BMP-2 hits identified in the screening assay. (B) Compounds were retested in a dose-dependent manner (from nM to $\mu M)$ under the same seeding and culture conditions. We identified quinacrine and niclosamide as BMP-2 modulators. (C) TGF- $\beta 1$ hits found in the screening assay. (D) Compounds were retested in a dose-dependent manner (from $n M$ to $\mu M$ ) under the same seeding and culture conditions. We identified vorinostat and hycanthone as TGF- $\beta 1$ modulators. $R L U$, relative light units.

day 1, 5 and 10. For BMP-2 modulators our results showed a statistical significant increase in metabolic activity for quinacrine $(250 \mathrm{nM})$ and niclosamide $(100 \mathrm{nM})$ when compared to rhBMP-2 (Figure 3A). Moreover, for the time and concentrations tested herein, an increase in metabolic activity during time was observed for all concentrations, with exception of quinacrine $(5 \mu \mathrm{M})$ and niclosamide $(1 \mu \mathrm{M})$ which inhibited metabolic activity both at day 5 and 10. Noteworthy, all the groups treated with rhBMP-2 or the BMP-2 modulators showed lower metabolic activity relative to BM suggesting that both BMP-2 and BMP-2 modulators reduce the metabolic activity of huTCs cultures, possibly by reducing cell proliferation in favour of cell differentiation.

For TGF- $\beta 1$ modulators, all concentrations showed an increase in metabolic activity during the first 5 days. However, when compared to rhTGF- $\beta 1$ and BM control, the metabolic activity for all the concentrations tested was statistically significant reduced with exception of $100 \mathrm{nM}$ hycanthone. At day 10, metabolic activity either reached a 

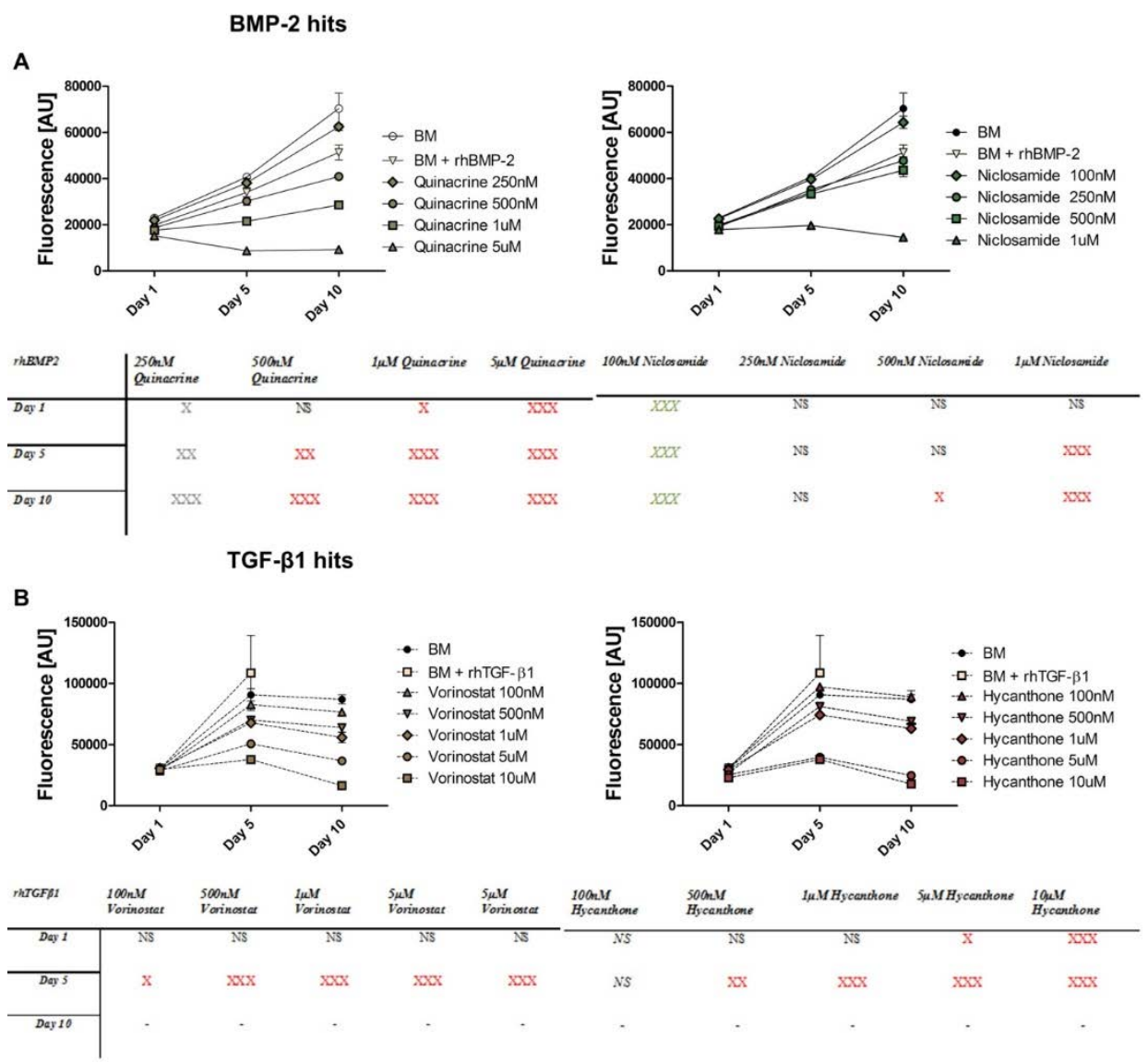

Figure 3. Metabolic activity of huTCs exposed to (A) BMP-2 and (B) TGF- $\beta 1$ modulators in a dose- and time-dependent manner. Positive control are cells cultured in the presence of $2.5 \mathrm{nM}$ rhBMP-2 or $0.8 \mathrm{nM}$ rhTGF- $\beta 1$, while negative control are cells cultured in basic media. Note: rhTGF- $\beta 1$ positive control was lost at day 10 due to confluent cell layer and pellet cell formation. Statistically significant difference is represented in the table, where green stands for a statistical significant increase and red for decrease in metabolic activity compared to rhBMP-2 or rhTGF- $\beta 1$ control, with $X X X p<0.001, X X p<0.01$ and $X p<$ 0.05. NS, not significant.

plateau or became partially inhibited, possible due to high number of cells which, in the case of TGF- $\beta 1$ control, led to cell detachment and pellet formation by day 10 (Figure 3B).

Following, as the concentrations found to induce BMP-2 and TGF- $\beta 1$ activation in the reporter cells inhibited the metabolic activity of huTCs, we decided to test whether acute exposure (24h) rather than chronic exposure (10 days) could modulate both signalling pathways in huTCs. 


\section{Identified hits modulate BMP-2 and TGF- $\beta 1$ target gene expression}

To examine whether the identified hits modulate the expression of genes involved in BMP-2 or TGF- $\beta 1$ pathway signalling, we analysed the expression of a panel of genes after acute exposure (24h) of huTCs to the to the selected hits.

Our results showed that $100 \mathrm{nM}$ niclosamide significantly increased the expression of Collagen IA1 (COL1A1) by 1.3 -fold \pm 0.2 , followed by a trend in increased expression in runt related transcription factor 2 (RUNX2) by 0.7 -fold \pm 0.3 , alkaline phosphatase, liver/bone/kidney (ALPL) by 0.6-fold \pm 0.3 , BMP2 by 0.4 -fold \pm 0.3 and BMP4 by 0.4 fold \pm 0.2 , when compared to both BM and rhBMP-2 control. Next, we found that $5 \mu \mathrm{M}$ quinacrine significantly increases the expression of BMP2 and BMP4 by $2.8 \pm 0.4$ but not the expression of other osteogenic target genes, which were significantly downregulated when compared to both BM and rhBMP-2 control (Figure 4A).

For the TGF- $\beta 1$ hits, our results showed that exposing huTCs to vorinostat partly induced expression of tendon and extracellular matrix (ECM) genes. Compared to BM, both 5 and $10 \mu \mathrm{M}$ vorinostat significantly increased the expression of SCX by $0.6 \pm 0.1$ and 1.5-fold \pm 0.1 , TIMP metallopeptidase inhibitor 1 (TIMP1) by 0.8 -fold \pm 0.04 and 1 -fold \pm 0.2 and TIMP3 by 0.6 -fold \pm 0.03 and 1 .1-fold \pm 0.2 . Additionally, further increase, though not statistically significant, was observed for TNC by 0.3 -fold \pm 0.03 and 0.2 -fold \pm 0.2 , and matrix metallopeptidase 1 (MMP1) by $0.7 \pm 0.4$ and $0.5 \pm 0.4$. COL 1A1, COL 3A1 and MMP3 remained at comparable levels to BM. In contrast to vorinostat, 5 and $10 \mu \mathrm{M}$ hycanthone showed an inhibition of all genes with exception of MMP1 and MMP3 where a statistically significant increase was observed for the highest concentration tested (Figure 4B).

Similar results were obtained with a second donor (Supplementary Figure 3).

\section{BMP-2 and TGF- $\beta 1$ hits modulate SMAD nuclear translocation}

To disclose the mechanism of action of the identified BMP-2 and TGF- $\beta 1$ hits, we investigated how they modulate SMAD nuclear translocation in huTCs. To do so, cells were exposed to the selected hits for $30 \mathrm{~min}$ or 2 hours and SMAD1/5/8 (BMP-2 signalling pathway) or SMAD2/3 (TGF- $\beta 1$ signalling pathway) nuclear translocation was analysed using immunocytochemistry.

Exposure of huTCs to BMP-2 hits for 30 minutes or 2 hours in BM or SM did not affect SMAD1/5/8 nuclear translocation. Although not statistically significant, after 30 minutes a trend towards increased SMAD1/5/8 nuclear translocation was observed for 5 $\mu \mathrm{M}$ quinacrine and $1 \mu \mathrm{M}$ niclosamide and after 2 hours for 100 and $500 \mathrm{nM}$ niclosamide. 
BMP-2 hits

A
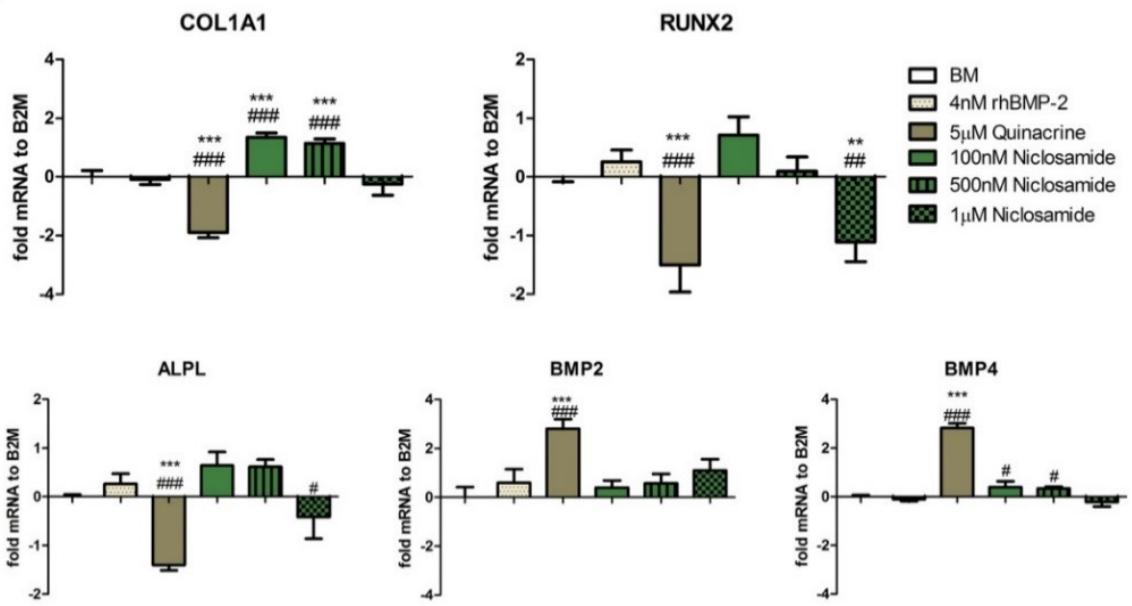

TGF- $\beta 1$ hits

B

COL1A1

COL3A1
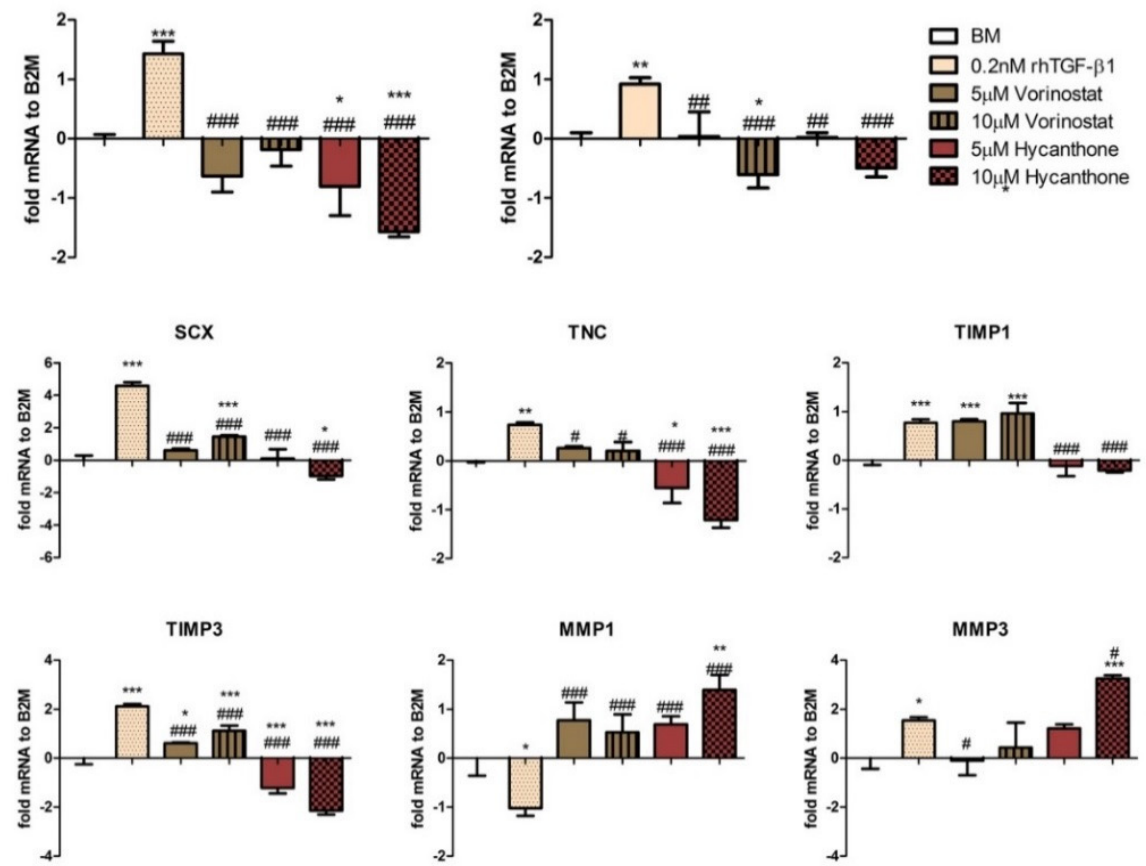

Figure 4. Gene expression analysis of huTCs exposed for 24 hours to (A) BMP-2 and (B) TGF- $\beta 1$ modulators. Statistically significant differences were analysed between BM and BMP-2/TGF- $\beta 1$ modulators (*) or between rhBMP-2/rhTGF- $\beta 1$ and BMP-2/TGF- $\beta 1$ modulators (\#), with ***/\#\#\#p $<0.001$, **/\#\#p $<0.01$ and $* / \# p<0.05$. 

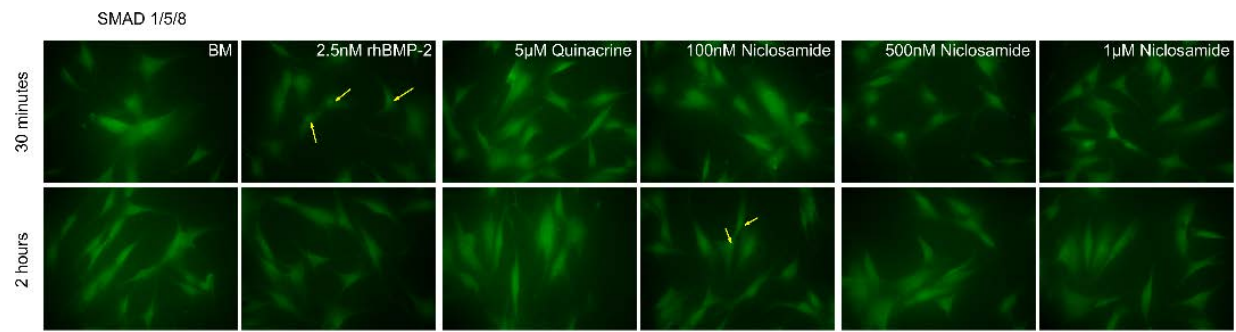

SMAD 2/3

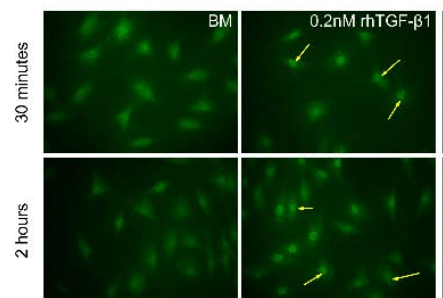

SMAD $1 / 5 / 8$

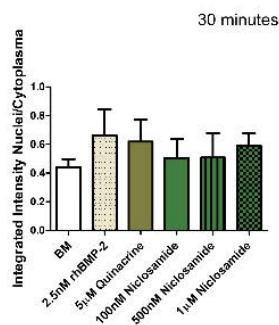

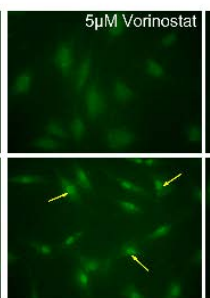

2 hours

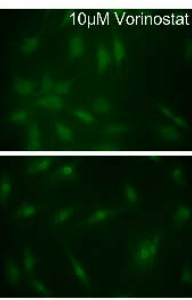

SMAD 2/3
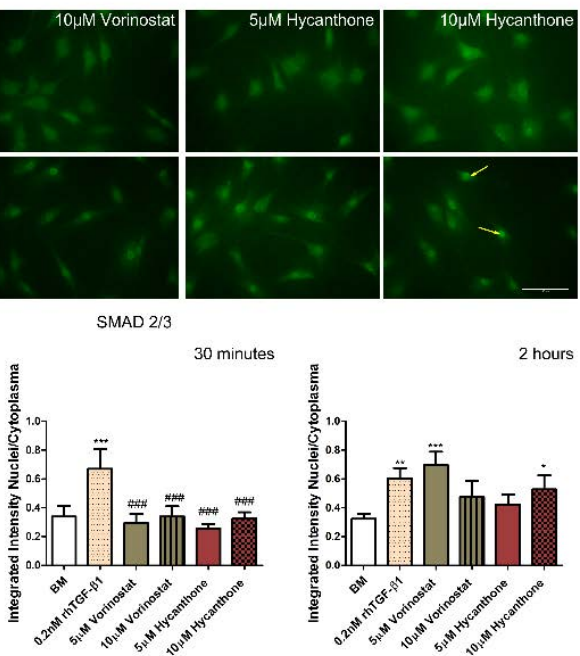

Figure 5. Immunofluorescence staining of SMAD1/5/8 and SMAD2/3 on huTCs exposed to BMP-2 or TGF- $\beta 1$ modulators for 30 minutes or 2 hours. Yellow arrows indicate SMAD nuclear translocation. Quantification of SMAD1/5/8 or SMAD2/3 nuclear translocation is presented as a ratio between integrated staining intensity between nuclei and cytoplasm. Values are represented as mean \pm standard deviation of at least three independent pictures from different wells $(n \geq 3)$. Statistically significant differences were found only when comparing BM with TGF- $\beta 1$ modulators (*) or rhTGF- $\beta 1$ with TGF- $\beta 1$ modulators (\#). Scale bar corresponds to $100 \mu \mathrm{m}$.

For the identified TGF- $\beta 1$ hits, exposure of huTCs to the selected hits for 30 minutes did not increase SMAD2/3 nuclear translocation when compared to BM. However, after 2 hours exposure to $5 \mu \mathrm{M}$ vorinostat and $10 \mu \mathrm{M}$ hycanthone a statistically significant increase in SMAD2/3 nuclear translocation was observed compared to BM. Interestingly, this increase was similar to the one observed with rhTGF- $\beta 1$ control (Figure 5).

\section{BMP-2 hits modulate ALP activity}

Following the increase in metabolic activity and in the expression of osteogenic genes upon exposure of huTCs to $100 \mathrm{nM}$ niclosamide we decided to analyse its effect on ALP activity, an early marker for in vitro osteogenesis. During a 7 days exposure of huTCs to $100 \mathrm{nM}$ niclosamide the ALP activity did not increase neither interfered with 
BMP2-mediated increase in ALP activity (Figure 6A). Additionally, exposure of huTCs to $5 \mu \mathrm{M}$ quinacrine during 7 days led to cell death and consequently no ALP activity could be analysed.

\section{TGF- $\beta 1$ hits modulate collagen production}

To investigate whether vorinostat influences the production of ECM we exposed huTCs to 5 and $10 \mu \mathrm{M}$ vorinostat, intermittently for 2 hours a day, for 10 days and analysed collagen production using a picrosirius red staining. Our results demonstrate that, as expected, exposure of huTCs to rhTGF- $\beta 1$ led to an increase in collagen production whereas exposure to vorinostat, regardless of the concentration used, did not increase collagen production (Figure 6B).

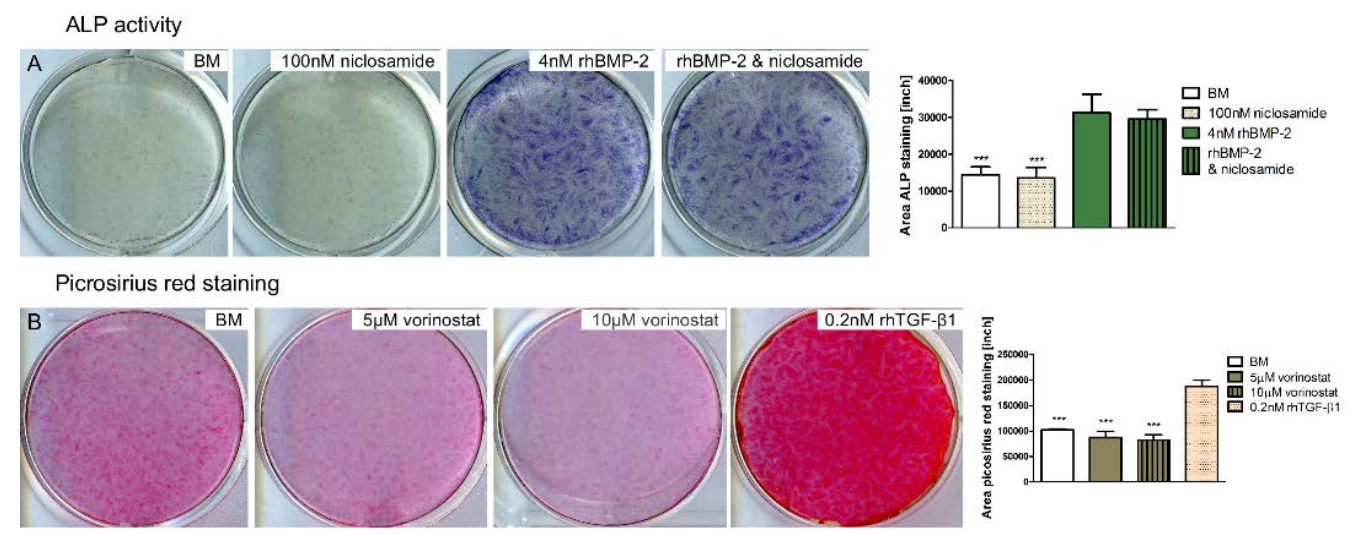

Figure 6. (A) ALP activity staining of huTCs exposed to niclosamide and rhBMP-2 for 7 days. (B) Picrosirius red staining of huTCs exposed to vorinostat intermittently for 2 hours each day, during a period of 10 days. The intensity of ALP and picrosirius red staining was quantified using Fiji open-source software and statistically significant differences were identified between rhBMP-2/rhTGF- $\beta 1$ and the other conditions, with ***p $<0.001$ and $* * p<0.01$.

\section{Discussion}

In this study we aimed to identify FDA-approved compounds capable of modulating BMP and TGF- $\beta$ signalling. The identification of such molecules could pave the way to new therapies capable of inducing bone and matrix formation, key actors in tendon/ligament enthesis formation [15] and middle core repair [16, 17]. Currently, the only approved drug that stimulates bone formation is parathyroid hormone (PTH), which was lately reported to stimulate bone resorption while increasing bone mineral density [18]. Furthermore, rhBMP2 was approved as a bone graft substitute to achieve fracture repair in clinical use [19]. However, the need to use supra-physiological doses and the high production costs creates a barrier for routine clinical application and emphasizes the need to discover new bone anabolic agents that either replace or reduce the basal concentration of rhBMP-2 used in patients. rhTGF- $\beta$ has not been approved 
for clinical application. Other than the previously described compounds, there are no other FDA-approved compounds that modulate the TGF- $\beta$ pathway.

We screened a commercially available library of FDA-approved compounds using genetically modified reporter cell lines for BMP-2 and TGF- $\beta 1$, and identified several small molecules that modulate BMP and TGF- $\beta$ signaling pathways. Dose-response curve analysis led to the identification of two BMP-2 (quinacrine dihydrochloride dehydrate and niclosmaide) and two TGF- $\beta 1$ (hycanthone and vorinostat) candidates. All four compounds have been previously described in literature to have antineoplastic potential, showing different mechanism of action. Quinacrine has been described to intercalate with DNA, inhibit some flavoprotein enzymes and uncouple oxidation and phosphorylation [20]. Niclosamide has been described to inhibit glucose uptake, oxidative phosphorylation and anaerobic metabolism [21, 22]. Hycanthone has been described to intercalate into DNA and inhibit RNA synthesis in vitro [23] and vorinostat is a powerful reported histone deacetylases inhibitor [24].

According to their antineoplastic properties, we were concerned that the identified compounds may dominate our screen with antiproliferative properties, which we identified by a decrease in metabolic activity for quinacrine, vorinostat, hycanthone but not for niclosamide. Following, we decided to test whether acute exposure (24h) rather than chronic exposure (10 days) could modulate both signalling pathways in TCs and investigated transcriptional activation of BMP and TGF- $\beta$ responsive genes. Niclosamide (100 nM) was found to induce expression of BMP signalling genes, in line with a recent study that screened for osteogenic compounds using a SP7:luciferase transgenic zebrafish model and where niclosamide was identified as a potential lead osteogenic compound [25]. In an attempt to better understand its function we screened the literature and found that niclosamide treatment does not inhibit the Wnt/ $\beta$-catenin signalling pathway [26], which can act downstream of BMP-2 signalling to promote osteoblast cell fate decision in multipotent progenitors [27]. We also showed that quinacrine induces expression of BMP signalling genes (BMP2 and BMP4) in both donors and reached up to 4 times higher levels than the addition of rhBMP-2 alone. This finding corroborates with a previous study reporting that quinacrine stimulates endogenous BMP-2 upregulation in vitro [28]. According to literature and based on our findings, we believe that quinacrine specificity to intercalate with the DNA [29] is not random but rather selective, as we and others have shown that it promotes BMP transcription and where future expertise is needed.

From the TGF- $\beta 1$ modulators we have shown that only vorinostat, but not hycanthone, induces the expression of TGF- $\beta$ responsive genes, like SCX, TNC, TIMPs and MMPs. As a HDAC inhibitor, vorinostat upregulates the cellular acetylation level, and therefore accelerates the natural epigenetic process [30] that we believe to potentially be of great help during tendon remodeling.

So far, we have shown that our identified compounds modulate the expression of BMP2 and TGF- $\beta 1$ target genes. However, we could not observe an increase in ALP activity for niclosamide and quinacrine and neither did we observed an increase on ECM 
production in huTCs exposed to vorinostat. Our concern that the antiproliferative or cytotoxic effects of the compounds might hinder downstream assays to study the functionality of the cells turned out to be true for quinacrine but not for niclosamide or vorinostat. Even though we did not observe an increase in ALP activity in the presence of niclosamide or collagen production in the presence of vorinostat, the protein expression levels remained at comparable levels with basic media with no observable changes on cell morphology. By investigating whether the identified hits modulate BMP or TGF- $\beta$ signalling by modulating SMAD nuclear translocation, we found that even if vorinostat - but not niclosamide - affected SMAD nucleus translocation, their mechanism of action differ from the native TGF- $\beta 1$ and BMP-2 suggesting that other mechanisms may be involved.

Additionally, the reason why niclosamide and vorinostat, in contrast with rhBMP-2 and rhTGF- $\beta 1$, did not show an effect on the selected functional assays - ALP and ECM production, respectively - suggests that an increase in mRNA production does not necessary translate to an increase in protein levels. These results warrant further studies to unravel the relation between transcription and translation of the target proteins in huTCs with special emphasis on the molecular regulators of ALP activity and ECM production and turnover.

Moreover, with the advent of gene editing technologies such as the CRISPR/Cas9, one could accelerate the discovery of compounds capable of modulating the endogenous promoters in the cellular context of interest rather than using minimal promoter(s) cloned on reporter plasmids. This is highly relevant for future work since it is wellrecognized that the genetic and epigenetic landscape of a given promoter is a key modulators of its activity [31].

\section{AbbreViations}

Bone morphogenetic protein 2 (BMP-2); recombinant human bone morphogenetic protein 2 (rhBMP-2); transforming growth factor- $\beta 1$ (TGF- $\beta 1$ ); recombinant human transforming growth factor- $\beta 1$ (rhTGF- $\beta 1$ ); tendon/ligament (T/L); human tendon-derived cells (huTCs); growth factors (GFs); Food and Drug Administration (FDA); mink lung epithelial cells (MLEC); basic media (BM); starvation media (SM); fetal bovine serum (FBS); relative light units (RLU); scleraxis (SCX); alkaline phosphatase (ALP); extracellular matrix (ECM); collagen IA1 (COL1A1); runt related transcription factor 2 (RUNX2); alkaline phosphatase; liver/bone/kidney (ALPL); TIMP metallopeptidase inhibitor 1 (TIMP1); matrix metallopeptidase 1 (MMP1).

\section{ACKNOWLEDGEMENTS}

This work was supported by the University of Twente. 


\section{SUPPLEMENTARY FIGURES}

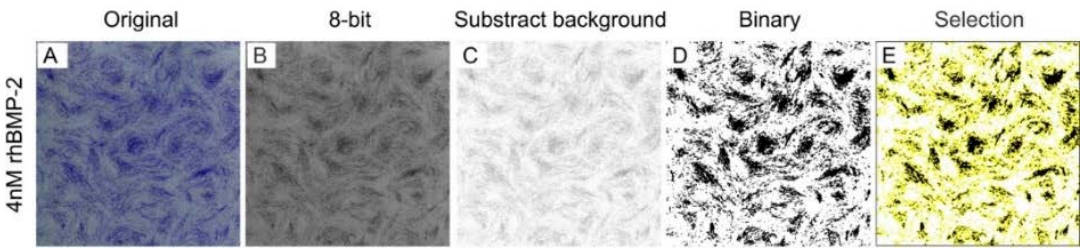

Supplementary Figure 1. Image based quantification of ALP staining on huTC using FIJI open source software. (A) Equal size squares were selected from the original image. (B) The squares were converted into 8-bit image. (C) The background was subtracted using rolling ball function. (D) The image was converted into a binary image. (E) The region of interest were selected and the area measured.

Pirlindole mesylate \& Pramipexole

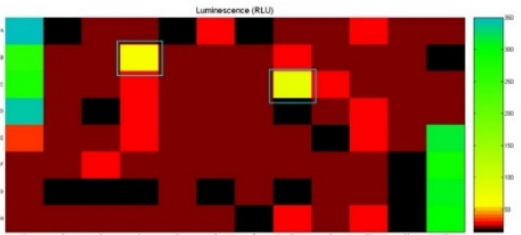

Butylscopolammonium bromide

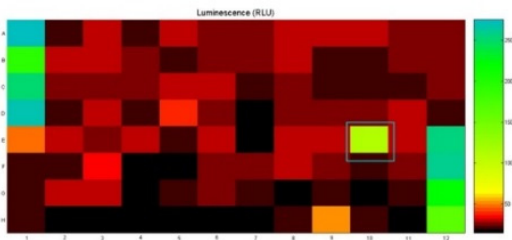

Chlorhexidine

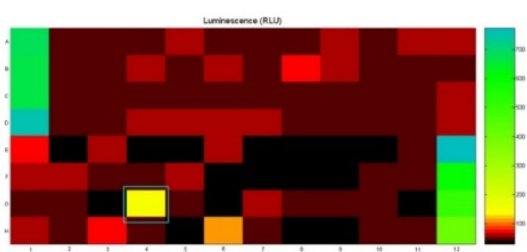

Vorinostat

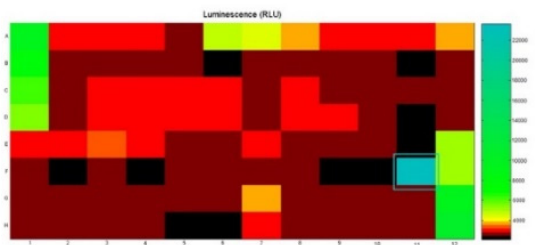

Nylindrin

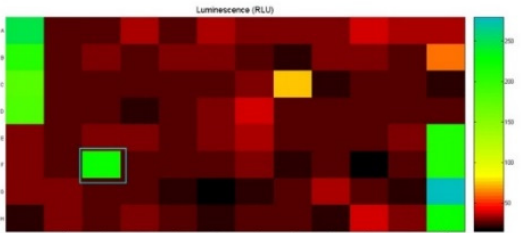

Quinacrine dihydrochloride

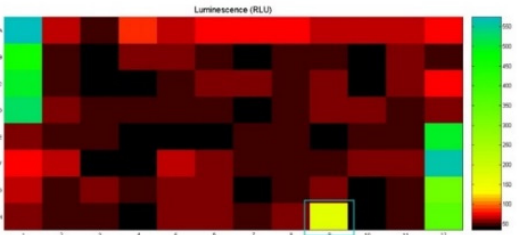

Niclosamide

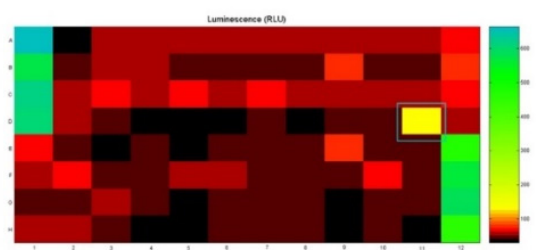

Hycanthone \& Etoposide

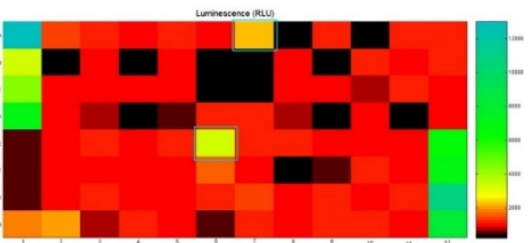

Supplementary Figure 2. Heat map of the identified hits in the 96 cell culture well plate. BMP-2 and TGF- $\beta 1$ reporter cells were exposed to the library of small molecules (2-11 A$H$ ) or to rhTGF- $\beta 1$ or rhBMP-2 positive control ( $1 A-D$ and $12 \mathrm{E}-\mathrm{H}$ ) and BM negative control (1E-H and 12A-D) and luciferase was measured. 
BMP-2 hits

A

COL1A1

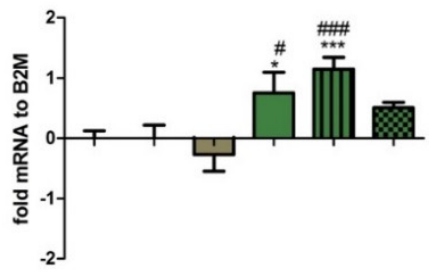

RUNX2

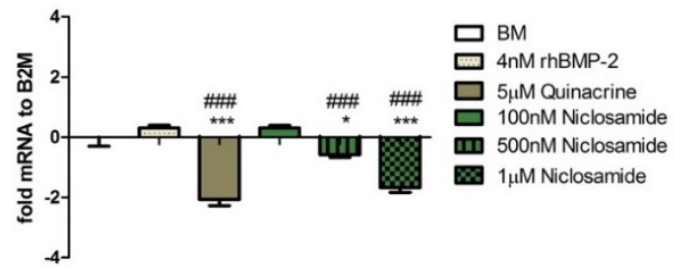

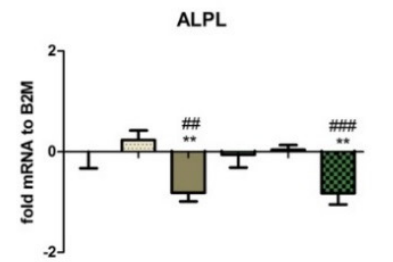
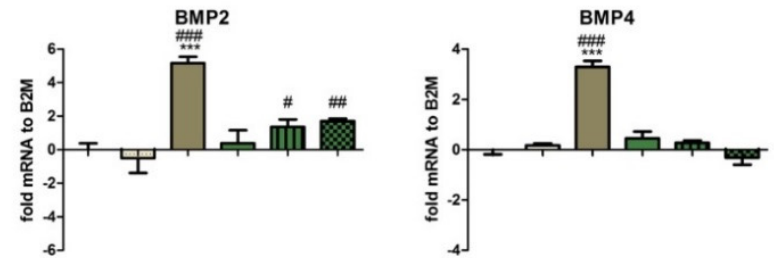

TGF- $\beta 1$ hits

B

COL1A1
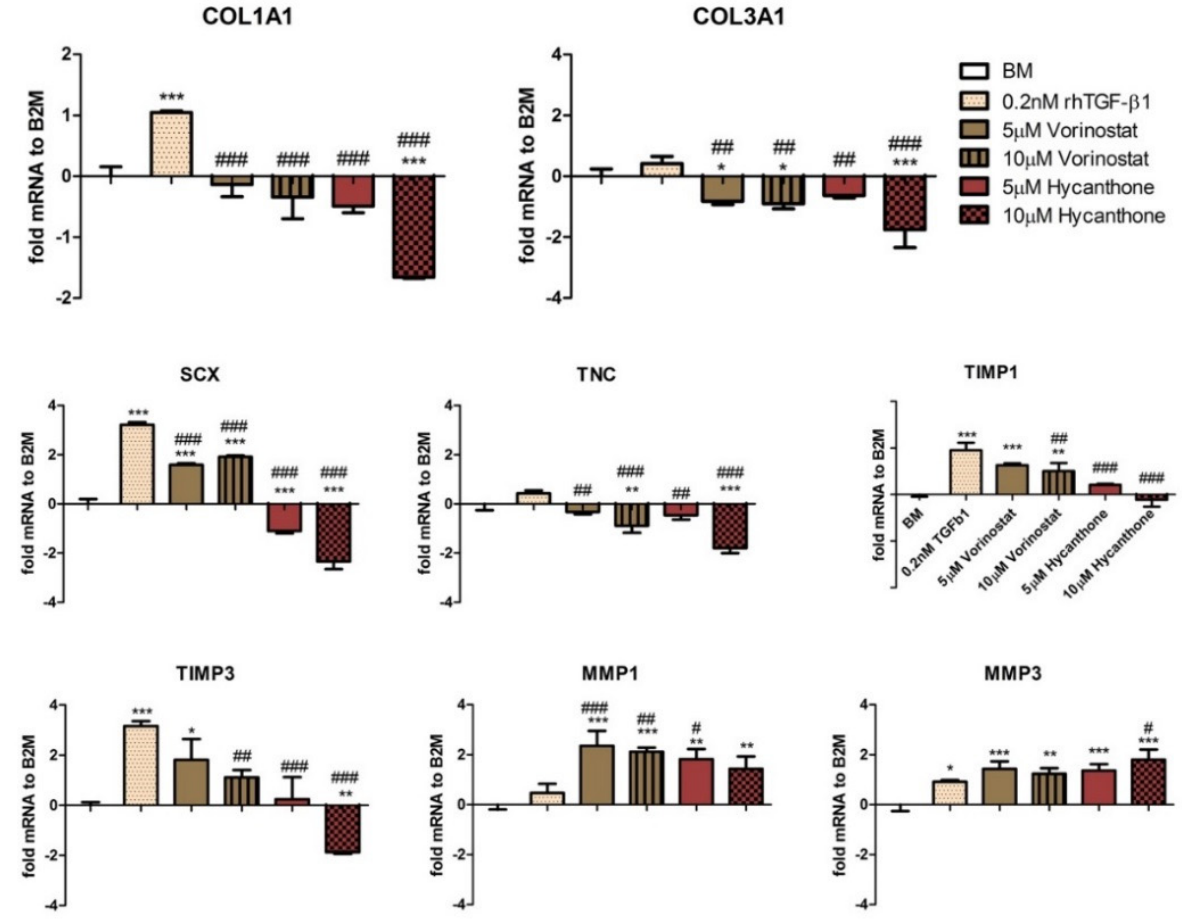

Supplementary Figure 3. Gene expression analysis of huTCs (second donor) exposed for 24 hours to (A) BMP-2 and (B) TGF- $\beta 1$ modulators. Statistical significant differences were analysed between BM and BMP-2/TGF- $\beta 1$ modulators $\left({ }^{*}\right)$ or between rhBMP-2/ rhTGF- $\beta 1$ and BMP-2/TGF- $\beta 1$ modulators (\#), with $* * * \# \# \# p<0.001$, **/\#\#p $<0.01$ and $* / \# p<0.05$. 


\section{REFERENCES}

1. Schweitzer, R.; Zelzer, E.; Volk, T. Connecting muscles to tendons: tendons and musculoskeletal development in flies and vertebrates. Development 2010, 137 (17), 2807-17.

2. Muller, S. A.; Todorov, A.; Heisterbach, P. E.; et al. Tendon healing: an overview of physiology, biology, and pathology of tendon healing and systematic review of state of the art in tendon bioengineering. Knee surgery, sports traumatology, arthroscopy : official journal of the ESSKA 2015, 23 (7), 2097-105.

3. Merino, R.; Ganan, Y.; Macias, D.; et al. Morphogenesis of digits in the avian limb is controlled by FGFs, TGFbetas, and noggin through BMP signaling. Dev Biol 1998, 200 (1), 35-45.

4. Soo, C.; Beanes, S. R.; Hu, F. Y.; et al. Ontogenetic transition in fetal wound transforming growth factor-beta regulation correlates with collagen organization. The American journal of pathology 2003, 163 (6), 2459-76.

5. Thomopoulos, S.; Kim, H. M.; Silva, M. J.; et al. Effect of bone morphogenetic protein 2 on tendon-to-bone healing in a canine flexor tendon model. Journal of orthopaedic research : official publication of the Orthopaedic Research Society 2012, 30 (11), 1702-9.

6. McMahon, P.; Kaplan, L. Anterior cruciate ligament injuries section of Sports medicine. Current Diagnosis and Treatment in Orthopedics 2006, 180-183.

7. Jenner, J. M.; van Eijk, F.; Saris, D. B.; et al. Effect of transforming growth factor-beta and growth differentiation factor- 5 on proliferation and matrix production by human bone marrow stromal cells cultured on braided poly lactic-coglycolic acid scaffolds for ligament tissue engineering. Tissue Eng 2007, 13 (7), 1573-82.

8. Ma, C. B.; Kawamura, S.; Deng, X. H.; et al. Bone morphogenetic proteins-signaling plays a role in tendon-to-bone healing: a study of rhBMP-2 and noggin. The American journal of sports medicine 2007, 35 (4), 597-604.

9. Garrison, K. R.; Donell, S.; Ryder, J.; et al. Clinical effectiveness and cost-effectiveness of bone morphogenetic proteins in the non-healing of fractures and spinal fusion: a systematic review. Health technology assessment (Winchester, England) 2007, 11 (30), 1-150, iii-iv.

10. Abe, M.; Harpel, J. G.; Metz, C. N.; et al. An assay for transforming growth factor-beta using cells transfected with a plasminogen activator inhibitor-1 promoter-luciferase construct. Analytical biochemistry 1994, 216 (2), 276-84.

11. Zilberberg, L.; ten Dijke, P.; Sakai, L. Y.; et al. A rapid and sensitive bioassay to measure bone morphogenetic protein activity. BMC cell biology 2007, 8, 41.

12. Ghebeş, C. A.; Kelder, C.; Schot, T.; et al. Anterior cruciate ligament- and hamstring tendon-derived cells: in vitro differential properties of cells involved in ACL reconstruction. Journal of tissue engineering and regenerative medicine 2015.

13. Carpenter, A. E.; Jones, T. R.; Lamprecht, M. R.; et al. CellProfiler: image analysis software for identifying and quantifying cell phenotypes. Genome biology 2006, 7 (10), 1-11.

14. Schindelin, J.; Arganda-Carreras, I.; Frise, E.; et al. Fiji: an open-source platform for biological-image analysis. Nat Meth 2012, 9 (7), 676-682.

15. Blitz, E.; Viukov, S.; Sharir, A.; et al. Bone ridge patterning during musculoskeletal assembly is mediated through SCX regulation of Bmp4 at the tendon-skeleton junction. Developmental cell 2009, 17 (6), 861-73.

16. Halper, J. Advances in the use of growth factors for treatment of disorders of soft tissues. Advances in experimental medicine and biology 2014, 802, 59-76.

17. Majewski, M.; Porter, R. M.; Betz, O. B.; et al. Improvement of tendon repair using muscle grafts transduced with TGF-beta1 cDNA. Eur Cell Mater 2012, 23, 94-101; discussion 101-2.

18. Rosen, C. J. Building bones by knocking down genes. Nature medicine 2012, 18 (2), 202-4.

19. Boyne, P. J.; Lilly, L. C.; Marx, R. E.; et al. De novo bone induction by recombinant human bone morphogenetic protein-2 (rhBMP-2) in maxillary sinus floor augmentation. Journal of oral and maxillofacial surgery : official journal of the American Association of Oral and Maxillofacial Surgeons 2005, 63 (12), 1693-707. 


\section{Chapter 5}

20. Dawson, R. M. C. E., D.C.; William, H.; Jones, K.M. Data for Biochemical Research. Oxford University Press: New York, 1986; Vol. 3.

21. Pampori, N. A.; Singh, G.; Srivastava, V. M. Cotugnia digonopora: carbohydrate metabolism and effect of anthelmintics on immature worms. Journal of helminthology 1984, 58 (1), 39-47.

22. Khanim, F. L.; Merrick, B. A.; Giles, H. V.; et al. Redeployment-based drug screening identifies the anti-helminthic niclosamide as anti-myeloma therapy that also reduces free light chain production. Blood cancer journal 2011, 1 (10), e39.

23. Wong, L. J.; Tsao, G. C.; Bruce, J. I.; et al. Inhibition of in vitro RNA synthesis by hycanthone, oxamniquine and praziquantel. Experientia 1990, 46 (5), 461-4.

24. Yoon, S.; Eom, G. H. HDAC and HDAC Inhibitor: From Cancer to Cardiovascular Diseases. Chonnam medical journal 2016, 52 (1), 1-11.

25. de Vrieze, E.; Zethof, J.; Schulte-Merker, S.; et al. Identification of novel osteogenic compounds by an ex-vivo sp7:luciferase zebrafish scale assay. Bone 2015, 74, 106-13.

26. Liao, Z.; Nan, G.; Yan, Z.; et al. The Anthelmintic Drug Niclosamide Inhibits the Proliferative Activity of Human Osteosarcoma Cells by Targeting Multiple Signal Pathways. Current Cancer Drug Targets 2015, 15 (8), 726-738.

27. Bain, G.; Müller, T.; Wang, X.; et al. Activated $\beta$-catenin induces osteoblast differentiation of C3H10T1/2 cells and participates in BMP2 mediated signal transduction. Biochemical and biophysical research communications 2003, 301 (1), 84-91.

28. Rossini, J. G. BMP-2 Upregulating Compounds For Healing Bone Tissue And Screening Methods For Selecting Such Compounds. Google Patents: 2012.

29. Sumner, A. T. Mechanisms of quinacrine binding and fluorescence in nuclei and chromosomes. Histochemistry 84 (4), 566-574.

30. Richon, V. M.; Emiliani, S.; Verdin, E.; et al. A class of hybrid polar inducers of transformed cell differentiation inhibits histone deacetylases. Proceedings of the National Academy of Sciences of the United States of America 1998, 95 (6), 3003-7.

31. Adam, R. C.; Fuchs, E. The Yin and Yang of Chromatin Dynamics In Stem Cell Fate Selection. Trends in genetics : TIG 2016, 32 (2), 89-100. 


\section{Chapter 6}

\section{Infographic \\ A View on the World of \\ Musculoskeletal Tendon and \\ Ligament Research}

Ghebeş C.A., van Eemeren T., Fernandes H.A.M. and Saris D.B.F. 


\section{THE CONTEXT OF DOING TENDON AND LIGAMENT RESEARCH:}

Increased participation in sport and ageing populations have raised the rates of musculoskeletal tendon/ligament (T/L) injuries. In the U.S. alone, this type of injury accounts for $50 \%$ of the 33 million injuries in the musculoskeletal system every year [1]. Decades of research on this problem has yielded extensive knowledge on the biological, structural, and biomechanical properties of these connective tissues. It has also advanced tissue engineering to new treatment strategies for T/L healing. On the world map, an overview of the past 14 years of research is presented. Even though this research has been translated into surgical advances that can prevent major disability, $\mathrm{T} / \mathrm{L}$ injuries remain a persistent clinical challenge. The current treatment strategies continue to fail to restore the properties of repaired tendons and ligaments to the level of native tissue.

\section{A GEOGRAPHICAL MAP PRESENTING THE RESEARCH FIELD OF T/L (PUBLICATIONS 2000-2014)}

We identified the main geographical regions that have contributed to advancements in the field of T/L research between $2000-2014$ by gathering and analysing a large body of literature. The geographical map presents a selection of scientists who contributed to the field, the number of articles they published, and how often these articles were cited. Publication and citation rates are used as a measure of academic performance by many global ranking schemes and academic institutions [2]. Nevertheless, these numbers should always be used with caution. Citations are a measure of the number of times a paper is cited by others as a reference but do not necessarily indicate the quality of the research. When there is a high citation rate, we assume that the work has influenced other scientists, but it does not necessarily mean that the paper has generated additional impact on society. Such caution must be taken into account also, given the fact that we have chosen to make use of these indicators to map the field of T/L research.

In this map, we highlighted countries or states that participate in T/L research by colouring them green. The research of single scientists mentioned in publications of the past few years is identified by means of circles positioned on top or proximate to their location. The size of the circle is an indication of the number of publications, and the number within the circle refers to the scientist listed in the legend. There can also be found the name, location, number of publications (indicated with a $P$ ), and sum of citations for these publications (indicated with a $C$ ).

We identified that:

- $\quad$ T/L research is found to be localised in North America, West Europe, East \& South Asia, and Australia.

- The density and size of circles on North America's east coast indicate it to be the hotspot of $\mathrm{T} / \mathrm{L}$ research. 
- The ratio between the number of publications and citations (not presented on this map) varies greatly. The map shows a distribution per publication achievements. This does not, however, necessitate high citation indices as well. We found scientists with a high number of citations relative to their limited number of publications (Tabin CJ; Schweitzer R; Lu HH; Altman GH \& Kaplan DL; Duprez D; and Shukunami C \& Hiraki Y). Likewise, we found scientists with a high number of publications relative to their lower citation indices.

- The type of research also has an influence on the number of citations. Published papers from basic science (that study nature of function, injury, and repair) have, in general, higher citation numbers than those from analytical science (which are concerned with tissue engineering strategies or biomechanical studies).

- The highest number of citations per publication is found in research attempting to understand the mechanisms underlining T/L embryonic development (Tabin CJ; Schweitzer R; Birk DE; Shukunami C \& Hiraki Y; and Duprez D).

\section{INTERESTS OF THE FIELD}

Generally, researchers tend to find solutions to more isolated problems, and not look at the field of T/L research as a whole. In publications concerned with these problems, scientists have identified various strategies, trends, and interests. We found six different categories to be most prevailing in these publications (found below), and they provided a proper overview of the research field. Though we did not find publications mentioning all six of these categories, to our knowledge, no other categories have been mentioned in a significant manner. We have classified the body of publications of this study in these six categories, placing each paper in one or more of these categories, and presented the results in the bar graph.

\section{The six categories:}

\section{Biology}

These studies include a wide range of research that focuses on describing the morphology, structure, and molecular biology of healthy T/L tissues, and how these are affected upon injury and repair. Additionally, it includes research describing the biological assembly of tissue engineered tendons and ligaments and the biological integration of engineered scaffolds.

\section{Scaffold \& Biomaterials}

In this area, a wide range of biological materials, biodegradable polymers and composite materials are developed. These are used to develop scaffolds, in various designs, that mimic the tissue structure and biomechanical properties native to tendons 

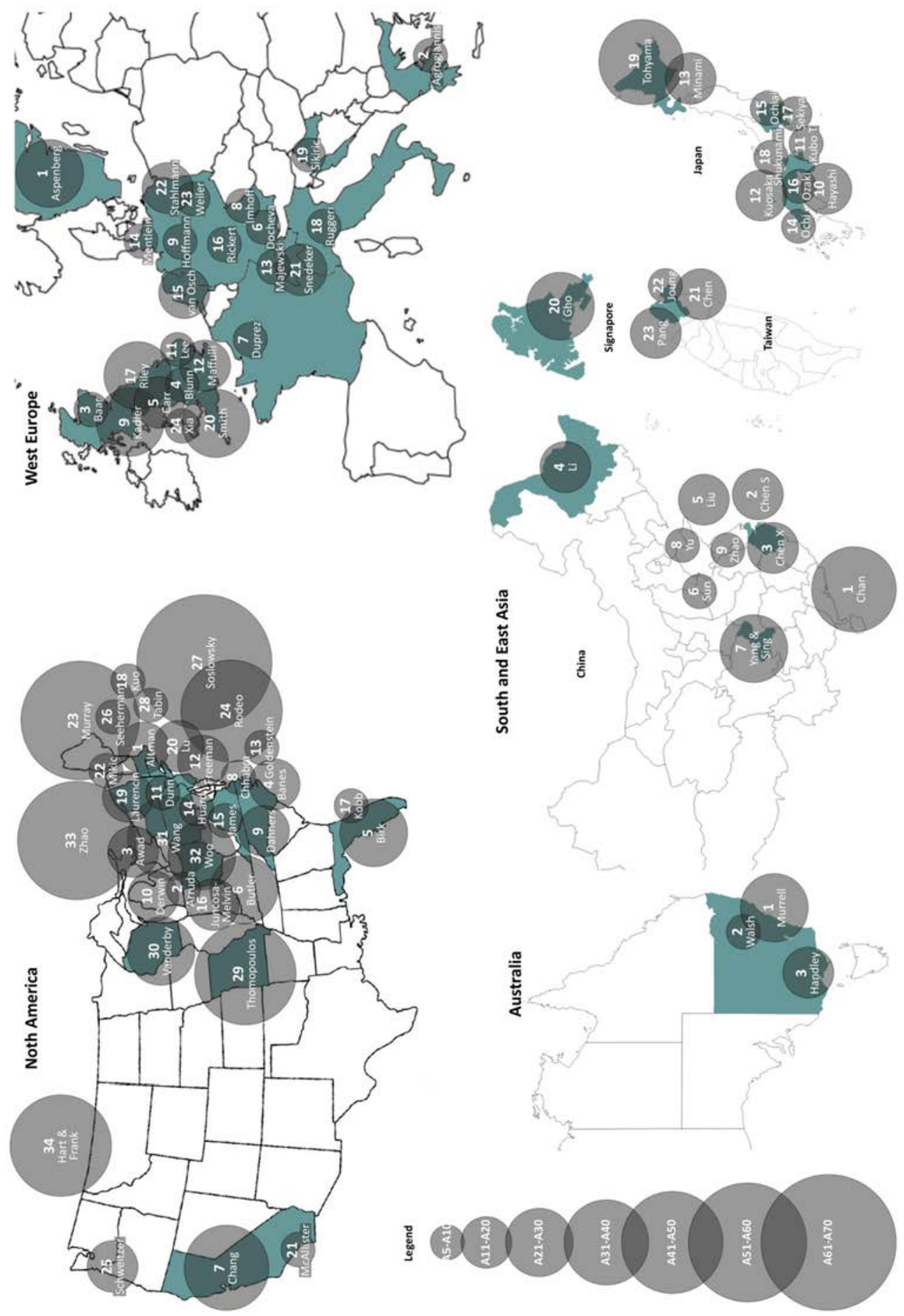

Figure 1. A geographical map presenting the field of musculoskeletal tendon and ligament research (publications 2000-2014). Legend per country: name; location; number of publications $(P)$; number of citations (C). 


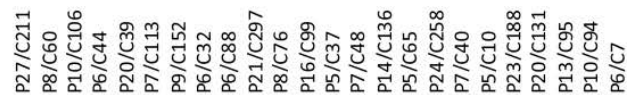

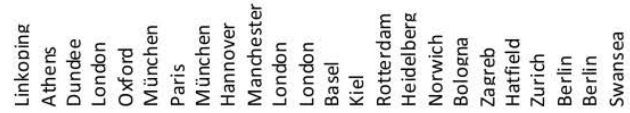

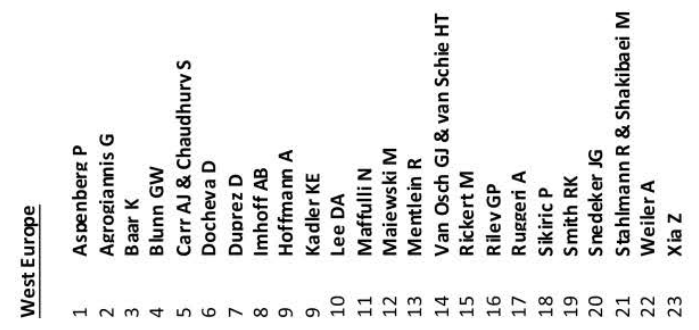

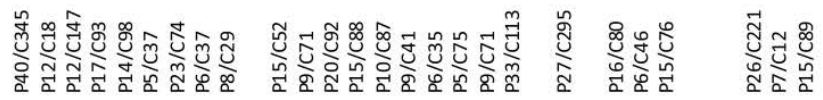

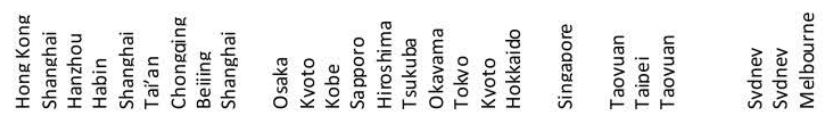

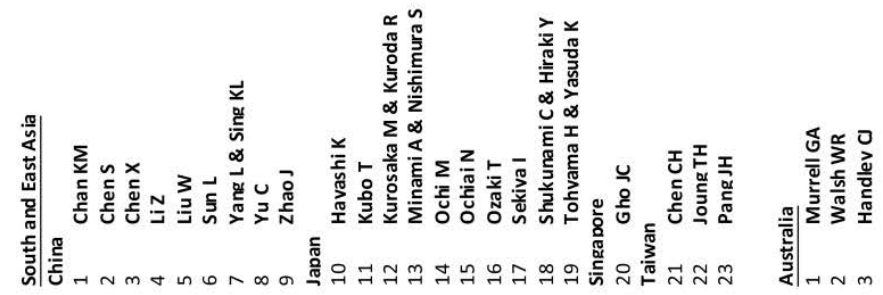

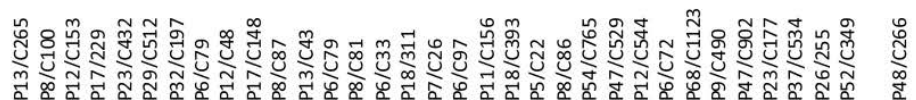

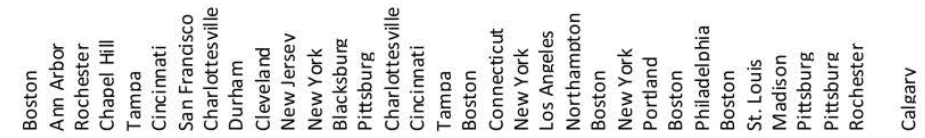

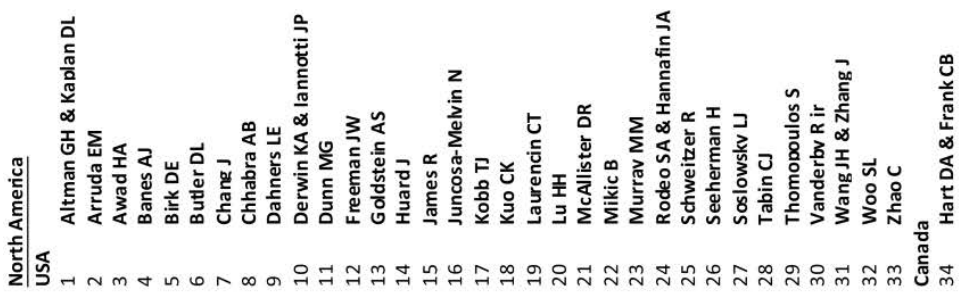


and ligaments. Ideally, the scaffold should support cell adhesion and must be biodegradable to enable tissue ingrowth, which is crucial for the new T/L to form.

\section{Biomechanics}

The biomechanical properties of native T/L tissue, subjected to a wide variety of loading conditions including tension, compression, and shear, as well as those of newly engineered scaffolds and T/L tissues, are the subject of this category.

\section{Bioactive molecules}

Papers fitting this category describe the influence of intrinsic or extrinsic delivered bioactive molecules, such as growth factors, and cytokines on T/L healing. They cover also the influence of oxygen tension and the delivery of pharmaceutical small molecules.

\section{Cell study}

This area describes the phenotypic properties of cells derived from T/L tissues; exploring new potential cell sources, as well as the use of genetically modified cells to enhance T/L healing.

\section{Developmental study}

This advances the understanding of $\mathrm{T} / \mathrm{L}$ development, which provides a basis of knowledge for improving T/L tissue repair, regeneration, and healing. The research of $\mathrm{T} / \mathrm{L}$ embryonic development has resulted in the discovery of important markers of tendon cell identity, matrix molecules, and signalling regulators.

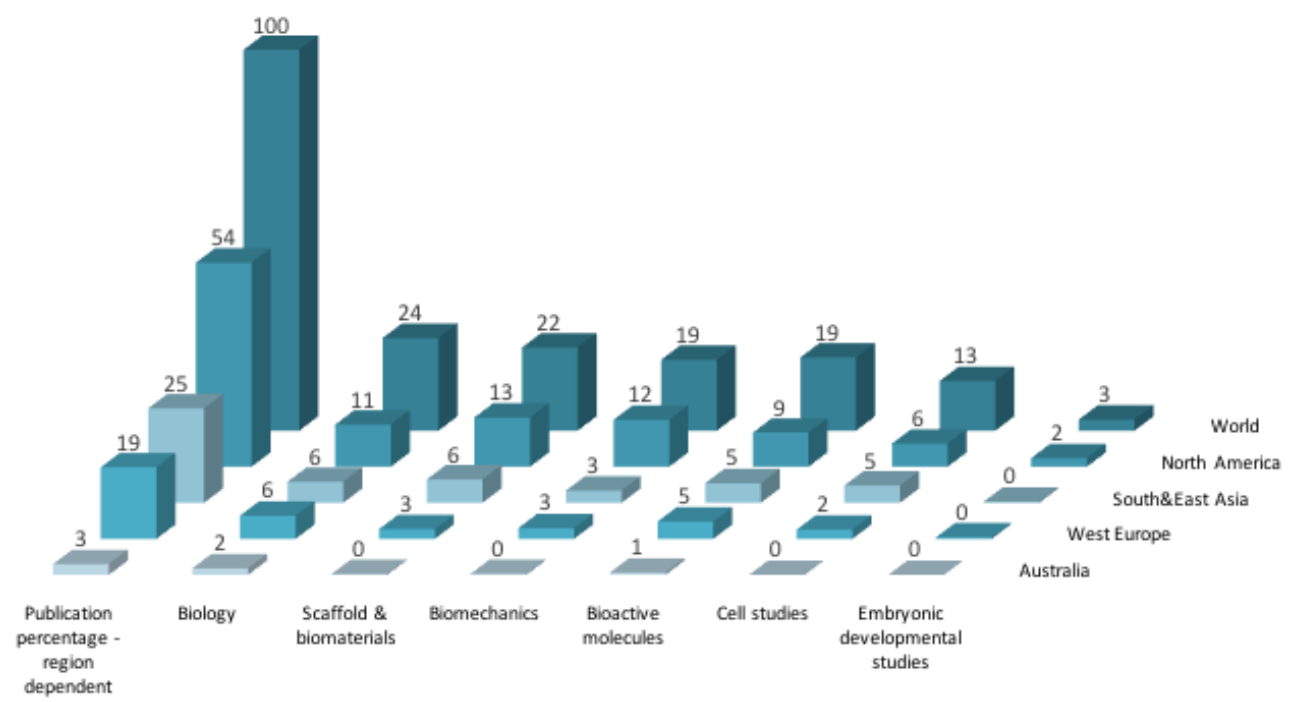

Figure 2. Tendon and ligament research interests 
In the bar graph, along the horizontal axis, the research is distributed across the different categories and, along the vertical axis, across the different world regions. Each bar represents a percentage of the total research (e.g. research on biomechanics in America makes up $12 \%$ of the total research). This graphic provides an overview of the type of research performed in different regions around the world during 14 years of research. North America, also in this graph, is shown to be the most significant contributor to the field. Asia and Europe together show a similar contribution to the field, with Australia taking up a significantly smaller percentage. Furthermore, in this graph, it becomes clear that even though the category of 'cell studies' shows a slightly lower percentage worldwide, the category of 'embryonic development' shows an especially significant lower percentage than the others. The latter coincides with issues previously addressed in various reviews that argue for further understanding to advance the field of $\mathrm{T} / \mathrm{L}$ research [3-5].

In conclusion, our approach of taking a step back and looking at the whole field, rather than at isolated problems, makes two points visible: that there are six main categories into which the field of T/L research can be classified, and that the category of embryonic developmental studies receives significantly less attention than others.

\section{Criteria of SElection}

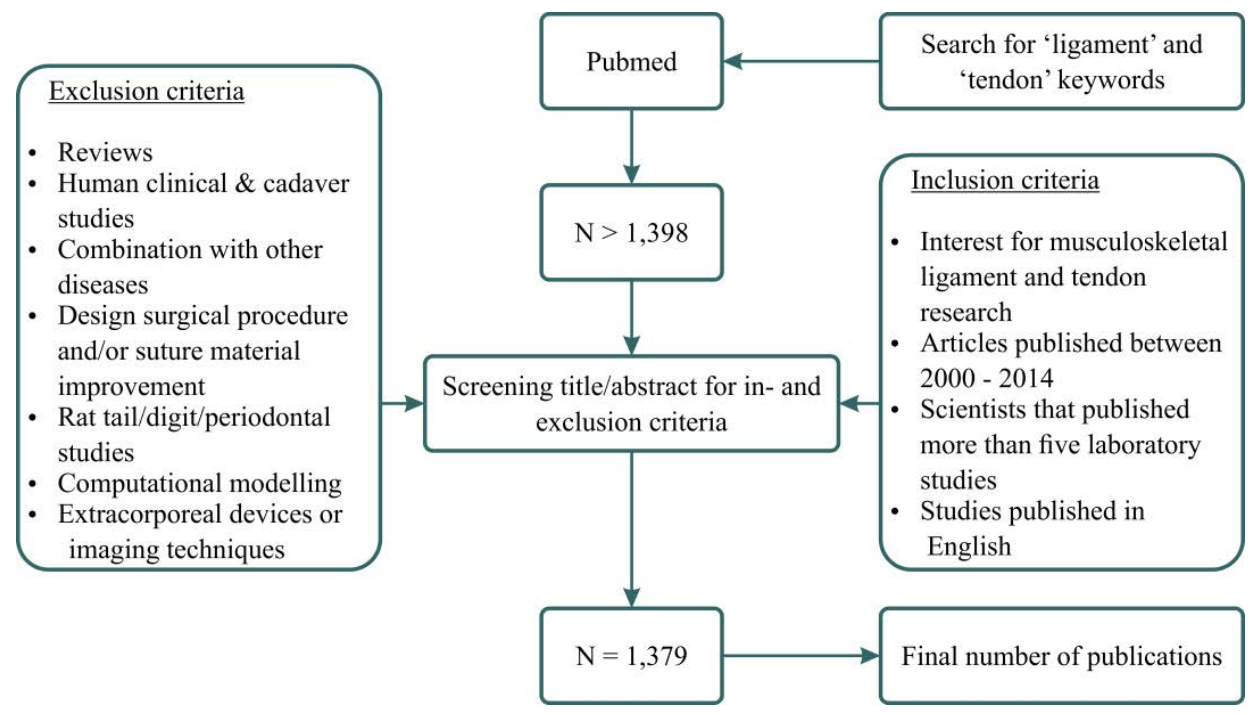

Figure 3. Search strategy and selection criteria 


\section{A PERSPECTIVE FOR INTERESTED RESEARCHERS AND OTHERS}

As a young researcher, it takes a lot of time and effort to get to know the field. Traditional means to achieve this are, among others, visiting conferences and keeping up to date on scientific literature in the field. The visual view of the world of musculoskeletal tendon and ligament research provided here aims to be an additional means to this end. It provides a quick overview of the main contributors to the field and the areas of interest.

Besides those interested from within the field, exterior parties that looking for collaborations, or interested in another way, could find in this map a coherent overview of possible business partners. 
A View on the World of Musculoskeletal Tendon and Ligament Research

\section{REFERENCES}

1. Moshiri A: Tendon and Ligament Tissue Engineering, Healing and Regenerative Medicine. Journal of Sports Medicine \& Doping Studies 2013, 03(02).

2. Cheol Shin J, Jeung Lee S, Kim Y: Research collaboration across higher education systems: maturity, language use, and regional differences. Studies in Higher Education 2013, 38(3):425-440.

3. Thomopoulos S, Genin GM, Galatz LM: The development and morphogenesis of the tendon-to-bone insertion - what development can teach us about healing. Journal of musculoskeletal \& neuronal interactions 2010, 10(1):35-45.

4. Rodrigues MT, Reis RL, Gomes ME: Engineering tendon and ligament tissues: present developments towards successful clinical products. Journal of tissue engineering and regenerative medicine 2012.

5. Andarawis-Puri N, Flatow EL, Soslowsky LJ: Tendon basic science: Development, repair, regeneration, and healing. Journal of orthopaedic research : official publication of the Orthopaedic Research Society 2015, 33(6):780-784. 



\section{Chapter 7}

\section{General Discussion}




\section{INTRODUCTION}

Curious about how we can accelerate and improve tendon-graft remodelling and about finding a new approach to biological augmentation of ACL reconstruction in the near future, we set out on this adventure.

With a rise in participation in organised sports, which has brought not only health benefits but also an increase in knee trauma and ACL ruptures, the desire of athletes to return to sports and others to resume their normal life in a the shortest time as possible calls for action. While the surgical procedure of ACL reconstruction is well established, the adaptation of the tendon graft to the new environment remains critical and seems to be the time limiting factor.

Multiple disciplines, including biology, engineering, material science, and chemistry, have converged to advance tendon-graft healing. We identified the emerging approaches that address this challenge, these include the administration of cells, that are able to differentiate into tissue specific cells or secrete bioactive factors important for tissue regeneration; growth factors, which provide important signals for tissue formation and differentiation; gene therapy techniques, which ensure the prolonged presence of molecules important for the healing process; bone derivatives, which provide fixation strength and bone-tendon ingrowth; biomaterials, which provide adhesion and fixation strength; and small molecules capable of modulating molecular signals. Thus, while these graft-enhancing methods have improved the structure and composition of the graft tissue, a major challenge remains in accelerating the healing process for early rehabilitation and a rapid return to full activity.

The native ACL attaches to the surface of bone through a direct insertion, which contains four distinct zones: ligament, uncalcified fibrocartilage, calcified fibrocartilage, and bone. In the human body, however, there are no sites where a tendon enters a bone tunnel, and therefore no native situation analogous to tunnel-tendon graft exists that can be resembled [1]. Tendon-graft healing appears to begin with the formation of fibrovascular tissue at the tendon-to-bone (T-B) interface, ingrowth of monocytes, macrophages, and bone marrow-derived cells; and progresses with a non-uniform pattern of cartilaginous interface and bone trabeculae, which reach a steady maturation after two years post-reconstruction [2]. The functional and structural recapitulation of the native counterpart, however, the enthesis, is never accomplished as result of the generation of a fibrovascular scar rather than regeneration of a graded fibrocartilaginous transition. The advantage of tissue regeneration over repair lies in the potential to mimic embryonic development, which results in the nearly complete reconstitution of the original structure, function, and mechanical properties of the tissue [3].

Consequently, tendon-graft healing following ACL reconstruction should ideally be accelerated and bear regenerative properties. In this thesis, we evaluated the tissue regenerative properties of the tendon graft versus the native ligament by analysing in vitro the phenotype of cells derived from each tissue. Similarly, we evaluated the tissue 
regenerative properties of $\mathrm{BM}$ cells harvested from different locations and their potential role in tendon-graft regeneration. Furthermore, inspired by embryonic development, where intercellular communication plays an important role in tissue formation, we addressed the potential influence of mature cells, derived from the same progenitor pool as tendon cells, on tendon-graft healing. Finally, we searched for therapeutic factors that can direct cell fate and influence tissue regeneration.

\section{Discussion}

To progress towards a successful healing of the reconstructed ACL, it is important to understand the differences and similarities between the native ACL and the replacement graft. In current surgical practice, the majority of procedures are performed using an autologous tendon graft due to its availability and similarity in structure, physiology, and mechanical properties to the native ACL $[4,5]$. One such graft is the hamstring tendon. Given the insufficient regenerative properties of the ACL tissue to heal following severe injury and the poor healing properties of the tendon graft, an understanding of the behaviour of the cells, derived from these two tissues, is important in order to harness their regenerative potential.

\section{The regenerative potential of cells involved in ACL reconstruction}

In Chapter 2 we analysed in vitro the phenotype of heterogeneous isolated cells from the ACL and the hamstring tendon graft. We found that ligament- and tendon-derived cells share similar biological properties in terms of morphology, gene expression profile, and cell surface markers, though not in terms of regenerative potential. Both cell types showed limited potential for self-renewal and trilineage differentiation, compared with the in vitro regenerative properties of MSCs described in the literature [6], and where tendon-derived cells showed even less regenerative properties than ligamentderived cells. Conversely, regenerative stem/progenitor cells were previously identified to reside in the ECM of tendons [7], albeit in reduced numbers. When inserted into a window-defect in a rat patellar tendon, after being expanded in vitro, they significantly promoted healing with increased collagen production and alignment, cell alignment, and overall increase in ultimate stress [8]. Nevertheless, this limited cell population is insufficient to contribute to natural tissue regeneration, unless it is expanded in vitro. Our findings suggest that the poor in vitro regenerative properties of the derived cells can explain the poor in vivo regenerative properties of the two tissues. Additionally, the inferior regenerative properties of the tendon graft compared to the replaced ACL tissue emphasises the major challenge remaining, i.e. to find means to accelerate tendon-graft regeneration and consequently ACL graft healing.

We addressed two distinctive methods/solutions, that may initiate tendon-graft regeneration. First, the regenerative properties of the graft tissue may be activated by the addition/implantation of an external cell source known to hold regenerative 
properties. Second, external factors that have the potential to instruct the biological system of the tendon graft and potentiate tissue regeneration.

Many of the therapeutic benefits seen in the augmentation of current surgical procedures are mediated by the activation of transplantation of MSCs [9]. Their effectiveness upon transplantation is mediated by their ability to differentiate into cells that participate in tissue regeneration, and due to the release of paracrine factors, such as growth factors and cytokines. From in vivo animal models, it is hypothesised that the presence of bone marrow-derived MSCs may improve tendon-graft regeneration and accelerate the repair process by laying down extracellular matrix, releasing growth factors, and triggering the necessary immune responses [10-12]. Nevertheless, to date, only one study has reported the use of BM concentrate harvest from the ilium to enhance ACL reconstruction healing [13]. The poor characterisation of the BM aspirate, however, like MNC concentration or cell viability, made it difficult to draw a conclusion regarding its contribution to tendon-graft healing. Thus, the challenge lies in optimising the treatment. We believe that an optimal treatment strategy to accelerate tendon-graft healing using $\mathrm{BM}$ aspirate would be to harvest $\mathrm{BM}$ proximal to the knee joint, to concentrate and/or activate it, and to place it back at the graft-bone insertion site. Collecting BM close to the ACL reconstruction site - either distal femur and/or proximal tibia - would not require an additional surgical step (as with BM harvested from the ilium) making it an appealing source to accelerate the healing process.

In Chapter 3, we evaluated means to enhance BM function for regenerative musculoskeletal applications. We determined the in vitro regenerative properties of MSCs isolated from different BM locations, including the ilium, proximal femur, distal femur, and proximal tibia. We found that the regenerative properties of the isolated MSCs differ in relation to the BM aspiration location, with larger amounts, higher selfrenewal, and osteogenic differentiation potential for MSCs isolated from the ilium rather than the distal femur and proximal tibia. Caution is needed regarding the results obtained, however, since the age of the BM donors is 50+ years and the patients we address, i.e. undergoing ACL reconstruction, is 20+ years. Previous studies have shown that an increase in donor age is associated with decreased proliferation rates and differentiation potential of the MSCs [14, 15], which illustrates that age is an important factor when analysing the regenerative potential of BM. For ACL reconstruction, the attractive regenerative properties of BM harvested from the ilium makes it to a valuable source of regenerative cells. It remains to be clarified, however, whether in young patients the regenerative properties of BM cells harvested from the distal femur and proximal tibia are comparable with those from ilium.

We evaluated also the potential use of acoustic energy to activate BM aspirate. Current in vivo animal studies have shown encouraging results using low-intensity pulsed ultrasound (LIPUS) as an extracorporeal method able to promote healing at the T-B interface following ACL reconstruction [16, 17]. Known to prime osteogenic differentiation of MSCs and enhance proliferation and differentiation of osteoblasts, we hypothesised that the direct application of acoustic energy on BM aspirate would 
activate MSCs prior to their reimplantation. We found that the application of acoustic stimulation on BM can increase self-renewal and the osteogenic differentiation potential of the MSCs, though not in all BM donors. This result represents the first attempt in exploring the use of acoustic stimulation as a system to prime BM cells. While further in vitro and in vivo investigations are needed, the use of acoustic stimulation as a tool to activate BM during its administration in ACL reconstruction surgery represents a feasible clinical approach.

\section{Therapeutic factors capable of modulating ACL graft healing}

\section{Remnant muscle tissue can accelerate ACL graft healing}

Cell-to-cell interactions are of crucial importance in the formation of connective tissues [18]. Upon maturation, however, these interactions are lost due to the abundant extracellular matrix surrounding the cells, which results in impaired tissue regeneration. Aiming to regenerate the original structure, function, and mechanical properties of the native ACL using a tendon graft, in Chapter 4 we analysed the influence of intercellular communication between tendon cells and cells involved in the development of tendon tissue. Using an in vitro co-culture system and evaluating the expression of genes that direct cell differentiation and extracellular matrix formation, we found that muscletendon cell interaction can play an important role on extracellular matrix remodelling. Considering such potential, the possibility of applying muscle tissue to enhance ACL reconstructive surgery appears attractive, because residual muscle is removed during preparation of the tendon graft. Using an in vivo ACL reconstruction rat model, we injected muscle tissue factors (muscle condition media) into the operated joints of the animals five times over a period of one month. Histological examination showed that femoral tunnel closure was promoted via muscle tissue factors. These positive in vitro and in vivo preliminary results emphasise that muscle tissue factors have an influence on tendon-graft matrix remodelling and can accelerate T-B junction integration. Nevertheless, our approach is, for now, insufficient to conclude whether muscle tissue factors have an influence on tendon-graft regeneration resembling the structure, function, and mechanical properties of native ACL. A more in detail evaluation of the muscle tissue modulatory factors and T-B junction remodelling/integration would make it possible to make that statement.

In this thesis, we described the potential use of muscle tissue factors; however, the preservation of muscle tissue itself on tendon grafts, as an envelope, could represent another feasible method to accelerate T-B junction integration. This method was previously described by Sun et al., who found that retention of muscle remnants on tendon grafts accelerated histological intra-articular healing of ACL reconstruction in a rabbit model [19]. Consequently, the use of remnant muscle represents a promising option to facilitate an early stage post-surgical rehabilitation and improve clinical outcomes for ACL reconstruction. 


\section{Small molecules capable of indirect modulation of ACL graft healing}

Small molecule-mediated tissue regeneration is emerging as a promising strategy for the regeneration of various tissues. Having unique advantages over other growth factors, such as no risk of cross-species contamination as with the use of recombinant proteinbased growth factors [20], and being more stable, highly soluble, and cost-effective [20], makes small molecules an important alternative to growth factors.

In this study, we searched for small molecules that can modulate two essential signalling pathways involved in tendon development and healing: TGF- $\beta$ and BMP (Chapter 5) [18, 21]. TGF- $\beta 1$ and BMP-2 reporter cell lines were used to screen a library of FDA-approved small molecules. The identified small molecules were further confirmed to mediate the expression of BMP-2 and TGF- $\beta 1$ target genes in primary tendon-derived cells. The translation to target proteins was not yet successful, however, when analysing functional assays, such as ALP activity and ECM production. The identified small molecules require much further preclinical in vitro and in vivo testing to confirm their beneficial role in tissue regeneration and their safety in future clinical applications.

\section{CONCLUSION}

Searching for methods to accelerate and improve ACL reconstruction, we identified differences in regenerative properties between the cells residing in the tendon graft and the injured ligament tissue. Unable to regenerate the tissue by themselves, we searched for an alternative cell sources with regenerative properties; and we illustrated three systems that have the potential to instruct the biological system of the tendon graft to regenerate and restore the biology and function of native tissue. At the preclinical incipient phase, these systems have the potential for future successful clinical applications.

- Exposing BM to acoustic energy prior to delivery of the activated cells at the tendon to bone junction is a new system with the potential to enhance tendon to bone junction integration via activation of MSCs pre-commitment towards osteogenesis.

- Co-delivery of small molecules (using a carrier system) that can provide different biological cues, such as ECM production and bone integration.

- Integration of muscle tissue factors at the tendon-graft site represents a new system that can promote intra-articular healing by graft remodelling and tendon to bone junction integration via ECM deposition. The 'tomorrow' strategy to accelerate ACL reconstruction healing, muscle tissue factors represents a good system that can be easily implemented into the clinical practice. 


\section{REFERENCES}

1. Benjamin M, Evans EJ, Copp L: The histology of tendon attachments to bone in man. J Anat 1986, 149:89-100.

2. Deehan DJ, Cawston TE: The biology of integration of the anterior cruciate ligament. The Journal of bone and joint surgery British volume 2005, 87(7):889-895.

3. Walsh WR: Repair and Regeneration of Ligaments, Tendons, and Joint Capsule: Humana Press; 2007.

4. Zhu J, Zhang X, Ma Y, Zhou C, Ao y: Ultrastructural and Morphological Characteristics of Human Anterior Cruciate Ligament and Hamstring Tendons. The Anatomical Record: Advances in Integrative Anatomy and Evolutionary Biology 2012, 295(9):1430-1436.

5. Tozer S, Duprez D: Tendon and ligament: development, repair and disease. Birth defects research Part C, Embryo today : reviews 2005, 75(3):226-236.

6. Murphy MB, Moncivais K, Caplan AI: Mesenchymal stem cells: environmentally responsive therapeutics for regenerative medicine. Experimental \& molecular medicine 2013, 45:e54.

7. Bi Y, Ehirchiou D, Kilts TM, Inkson CA, Embree MC, Sonoyama W, Li L, Leet AI, Seo BM, Zhang L et al: Identification of tendon stem/progenitor cells and the role of the extracellular matrix in their niche. Nature medicine 2007, 13(10):1219-1227.

8. Ni M, Lui PP, Rui YF, Lee YW, Lee YW, Tan Q, Wong YM, Kong SK, Lau PM, Li G et al: Tendon-derived stem cells (TDSCs) promote tendon repair in a rat patellar tendon window defect model. Journal of orthopaedic research : official publication of the Orthopaedic Research Society 2012, 30(4):613-619.

9. Murrell WD, Anz AW, Badsha H, Bennett WF, Boykin RE, Caplan AI: Regenerative treatments to enhance orthopedic surgical outcome. PM \& R : the journal of injury, function, and rehabilitation 2015, 7(4 Suppl):S41-52.

10. Hao ZC, Wang SZ, Zhang XJ, Lu J: Stem cell therapy: a promising biological strategy for tendon-bone healing after anterior cruciate ligament reconstruction. (1365-2184 (Electronic)).

11. Lim JK, Hui J Fau - Li L, Li L Fau - Thambyah A, Thambyah A Fau - Goh J, Goh J Fau - Lee E-H, Lee EH: Enhancement of tendon graft osteointegration using mesenchymal stem cells in a rabbit model of anterior cruciate ligament reconstruction. (1526-3231 (Electronic)).

12. Soon MY, Hassan A Fau - Hui JHP, Hui Jh Fau - Goh JCH, Goh Jc Fau - Lee EH, Lee EH: An analysis of soft tissue allograft anterior cruciate ligament reconstruction in a rabbit model: a short-term study of the use of mesenchymal stem cells to enhance tendon osteointegration. (0363-5465 (Print)).

13. Silva A, Sampaio R Fau - Fernandes R, Fernandes R Fau - Pinto E, Pinto E: Is there a role for adult non-cultivated bone marrow stem cells in ACL reconstruction? (1433-7347 (Electronic)).

14. Stolzing A, Scutt A: Age-related impairment of mesenchymal progenitor cell function. Aging cell 2006, 5(3):213-224.

15. Egrise D, Martin D, Vienne A, Neve P, Schoutens A: The number of fibroblastic colonies formed from bone marrow is decreased and the in vitro proliferation rate of trabecular bone cells increased in aged rats. Bone 1992, 13(5):355-361.

16. Walsh WR, Stephens P, Vizesi F, Bruce W, Huckle J, Yu Y: Effects of low-intensity pulsed ultrasound on tendon-bone healing in an intra-articular sheep knee model. Arthroscopy : the journal of arthroscopic \& related surgery : official publication of the Arthroscopy Association of North America and the International Arthroscopy Association 2007, 23(2):197-204.

17. Ying ZM, Lin T, Yan SG: Low-intensity pulsed ultrasound therapy: a potential strategy to stimulate tendon-bone junction healing. Journal of Zhejiang University Science B 2012, 13(12):955-963.

18. Schweitzer R, Zelzer E, Volk T: Connecting muscles to tendons: tendons and musculoskeletal development in flies and vertebrates. Development 2010, 137(17):2807-2817.

19. Sun L, Hou C, Wu B, Tian M, Zhou X: Effect of muscle preserved on tendon graft on intra-articular healing in anterior cruciate ligament reconstruction. Knee surgery, sports traumatology, arthroscopy : official journal of the ESSKA 2013, 21(8):1862-1868. 


\section{Chapter 7}

20. Lo KW, Ashe KM, Kan HM, Laurencin CT: The role of small molecules in musculoskeletal regeneration. Regenerative medicine 2012, 7(4):535-549.

21. Muller SA, Todorov A, Heisterbach PE, Martin I, Majewski M: Tendon healing: an overview of physiology, biology, and pathology of tendon healing and systematic review of state of the art in tendon bioengineering. Knee surgery, sports traumatology, arthroscopy : official journal of the ESSKA 2015, 23(7):2097-2105. 


\section{List of publications}

\section{Peer-ReVIeWed PAPERS}

Anterior cruciate ligament- and hamstring tendon-derived cells: In vitro differential properties of cells involved in ACL reconstruction.

Ghebeş CA, Kelder C, Schot T, Renard AJ, Pakvis DFM, Fernandes HA, Saris DB. J.

Tissue. Eng. Regen. Med. 2015 Mar; 11. Doi:10.1002/term.2009.

Means of enhancing bone fracture healing: optimal cell source, isolation methods and acoustic stimulation.

Ghebeş CA, Braham MVJ, Zeegers AVCM, Renard AJS, Fernandes HAM and Saris DBF. BMC Biotechnology. 2016 Dec 12; 16(1):89

Human muscle-derived factors accelerate ACL graft healing: an in vitro and in vivo analysis

CA Ghebeş, N Groen, YC Cheuk, SC Fu, H Fernandes and DBF Saris. Submitted

High-Throughput Screening Assay Identifies Small Molecules Capable of Modulating the BMP-2 and TGF-ß1 Signaling Pathway

Ghebeş CA, van Lente J, Post JN, Saris DBF and Fernandes HAM. J. Biomol. Screen. 2016 Sep; pii: 1087057116669346

Mesenchymal stromal cell-derived extracellular matrix influences gene expression of chondrocytes.

Thakkar S, Ghebeş CA, Ahmed M, Kelder C, van Blitterswijk CA, Saris D, Fernandes HA, Moroni L. Biofabrication. 2013 Jun;5(2):025003. doi: 10.1088/17585082/5/2/025003.

Cross-Talk Between Human Tenocytes and Bone Marrow Stromal Cells Potentiates Extracellular Matrix Remodeling In Vitro.

Ekwueme EC, Shah JV, Mohiuddin M, Ghebeş CA, Crispim JF, Saris DB, Fernandes HA, Freeman JW. J Cell Biochem. 2016 Mar;117(3):684-93. doi: 10.1002/jcb.25353.

Influencing chondrogenic differentiation of human mesenchymal stromal cells in scaffolds displaying a structural gradient in pore size.

Di Luca A, Szlazak K, Lorenzo-Moldero I, Ghebeş CA, Lepedda A, Swieszkowski W, Van Blitterswijk C, Moroni L. Acta Biomater. 2016 May; 36:210-9. doi: 10.1016/j.actbio.2016.03.014. 


\section{ABSTRACTS SELECTED FOR ORAL PRESENTATION}

Characterisation of hamstring tendon-derived cells and their crosstalk with neighbouring cell types involved in embryonic development of tendons.

CA Ghebeş, T Schot, C Kelder, E Ekwueme, AJ Renard, HAM Fernandes, DBF Saris. NBTE, 2013, The Netherlands.

Bio-instructive approach to accelerate ligament/tendon healing.

CA Ghebeş, N Groen, HAM Fernandes, DBF Saris. NBTE, 2014, The Netherlands.

Ways to enhance musculoskeletal repair.

CA Ghebeş, HAM Fernandes, DBF Saris. MIRA day, University Twente, 2015, The Netherlands.

\section{ABSTRACTS SELECTED FOR POSTER PRESENTATION}

Cell source for anterior cruciate ligament reconstruction.

HAM Fernandes, CA Ghebeş, C Kelder, C van Blitterswijk, DBF Saris. TERMIS, 2012, Austria.

Hamstring tendon-derived cells, a cell source for anterior cruciate ligament reconstruction.

CA Ghebeş, C Kelder, T Schot, AJ Renard, DFM Pakvis, HAM Fernandes, DBF Saris. Advances in Tissue Regeneration, 2013, The Netherlands.

Accelerating ACL repair by understanding cellular communication in soft tissue to bone healing.

CA Ghebeș, N Groen, J van de Peppel, JP van Leeuwen, HAM Fernandes, DBF Saris. ORS, 2014, USA.

\section{Patent}

Bone fracture healing with primed distal bone marrow mesenchymal stromal cells (WO/2016/029148)

Wan C, Hsiong S, Au A, Ghebeş CA. Smith \& Nephew Inc. and University of Twente. 


\section{Acknowledgements}

\section{To my dearest parents}

Dragi părinţi, vă mulţumesc pentru dragostea cu care m-aţi crescut şi omul care m-aţi făcut.

\section{To my supervisors}

To Daniel, I would like to acknowledge the support, trust and freedom I received in exploring my curiosity and becoming an independent scientist. I would like to thank you for the positive attitude you always expressed and that kept me going. I look forward to "get more" in life ;)

To Hugo, in am grateful for the great start I received in getting accustomed to the role of becoming a scientist. Getting familiar with cell culture, reading and discussing articles and improving my English by reading The Economist.

\section{To my paranymphs}

To Nick, with whom I left behind als laatste der Mohikanen! Dankjewel for your positive and vibrant attitude when things rumbled a little.

To Karina, my soul sister, always there when I was away from home and family. Danke!

\section{To the TR department}

Especially to my office mates - Nathalie, Wim and Vanessa - it was a fun office, with Nathalie I learned to row on the Twentekanaal, with Wim I explored Twente region on roller skates and with Vanessa I shared the love for dogs. Thank you!

To the TR family, it was one of the best time of my life. I was not aware of how well working together can be combined with having fun together. I found in you - Parthiban, Anne, Niloofar, Febryani, Paul, Mijke, Ana, Erik, Zyrian, Jingwei, Bach, David, Marloes, Anouk, Tom, Frits, Max - a friend rather than a colleague.

\section{To the DBE department}

Even if I was a guest in the group, I received full credentials. With my new office mates, Elahe and Tom, we became the most "sweet" office in the group. And with you, Milou, Sieger, Maurice, Leilei, Jan, Jaqueline, Janine, Ingrid Brenda, Rong, Kanan, I shared the chaos of my last months as a PhD student.

\section{To the Amber group}

I was always welcome to join your fun evenings, be it game -, French cheese evening or going out for drinks. Thanks to Adithia, JB, Darya and Severine 


\section{To the ligament group}

To Joao, Emmanuel, Maaike, Thijs, Razmara it was fun to work together. Thanks for the help and laughing moments we had.

To Jere, it was nice to find not only a student but also a friend.

\section{To my Austrian friends}

Far from Austria and still together. We kept seeing each other and explored new countries, new food and new drinks, extra hugs to Natalia, Emil, Lili, Marion, Alex and Dragos.

\section{To my friends from Twente}

Thank you for the great moments we shared.

\section{To Tjebbe}

Thank you for being there in the most challenging year of my life.

\section{To my friends from home}

To Eddy, Timeea and Karina (again) for the amazing fun we experience and for more new year eves together to come. To Irina, Diana, Mircea, Mona, Costin, Ioana, Simona for our lovely friendship. 


\section{BIOGRAPHY}

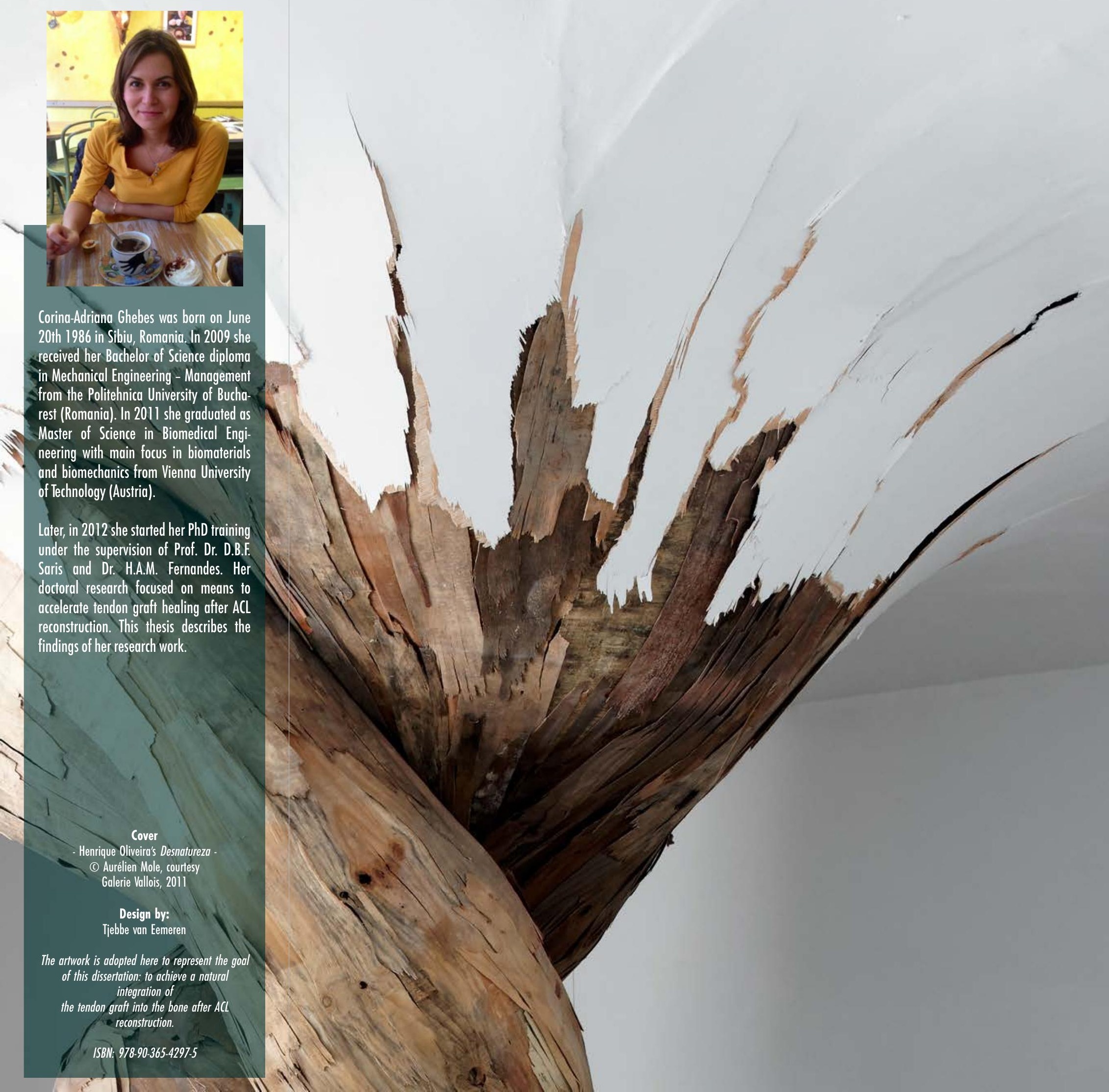

